\title{
Augustine On the Image of God: An Ethical Analysis
}

\author{
Matthew W. Puffer
}

Charlottesville, Virginia

Bachelor's of Science, North Carolina State University, 1999

Master's of Divinity, Princeton Theological Seminary, 2009

A Dissertation presented to the Graduate Faculty

of the University of Virginia in Candidacy for the Degree of

Doctor of Philosophy

Department of Religious Studies

University of Virginia

August 2014

(C) Matthew W. Puffer 
For Becca, Will, and Kate 
Abstract

Introduction

In the beginning of evil was the lie

The history and method of the project

How to read Augustine on the image of God

Part I. Augustine on the Image of God

I.1 Before Genesis: The image of God and the rational soul (386-388)

I.2 Turning Toward the Image of God in Genesis (388-390)

I.3 Augustine's Priesthood: On Genesis, the beatitudes, and Romans (391-395)

Excursus: A late addendum to De Genesi ad litteram liber inperfectus

Beatitudes as eights steps in moral progress

Four stages of humanity in Romans

I.4 The Bishop of Hippo Confesses a New Image of the Trinity (396-400)

The image of Caesar and the image of God

I.5 The Image of the Trinity and the Image of God in Christ (401-412)

The image of God lost and found

I.6 The Image of God in Five Trinities and Four Stages (413-426)

The trinities of the outer human

The trinities of the inner human: scientia and sapientia

Two trinities of faith

Image of God as activity

Image of God as capacity

Interpreting the image of God in eight biblical texts

I.7 Distinguishing Citizenships: Election and the image of the Son (420-430)

I.8 Seven Developments in Augustine's imago dei (396-430)

Part II. Ethics after the Image of God

II.1 Introduction: The Problem of Augustine's Ethics

Lying and killing in Augustine's ethics

The Augustinian image of God and religious ethics today

The image of God in Augustine's ethics

The image of God in Scriptural texts on lying 
II.2 Lying After the Image of God: De Trinitate 15

The analogy between the rational soul and the Trinity: Its basis and limits Immanent Trinitarian processions and the economic Christological mission The Trinitarian pre-linguistic "yes, yes; no, no" The Christological sign-assuming "yes, yes; no, no" Inseparable operations of the image of God ad extra Ignorance, errors, and lies: Finite knowledge, flawed intellect, and evil will Ignorance: Creaturely finitude of knowledge Errors: Unknowingly willing false words Lies: Knowing and willing false words

Divine omniscience, simplicity, and omnipotence

Exercising the image of God

II.3 Retracing Augustine's Ethics of Lying

Escaping deception and attaining perfection via steps and stages

Mt 5.37 and the ethics of swearing

Mt 5.37 and six theses on lying

Mt 5.37 in Christology and Scripture

Revisiting swearing: Moral dilemmas and outdoing murderers

Reframing lying in ecclesial and political contexts

Comparing lies: Priscillianist heresy and Catholic blasphemy

Comparing lies: Egypt, Jericho, and the heavenly Jerusalem

Laurentius: The necessity of error

II.4 Three Stages in Augustine's Moral Reasoning about Lying

The early ethics: Lying as imperfection in virtue

The later ethics: Lying, error, and necessity

De Trinitate 15: Lying as the origin of evil in the rational soul

Conclusion

Defining the lie and the voluntate fallendi

The limits of necessity

An Augustinian account of the image of God for today

Appendices

A: References to the image of God in Augustine's writings

B: Augustine's image of God in five trinities and four stages

C: Scriptural texts cited by Augustine in his primary expositions of lying

D: Scriptural texts cited by Augustine more than once in expositions of lying

E: Citations of Mt 5.37 by year

Bibliography 
Abstract

This dissertation addresses two questions: First, "What is the image of God for Augustine?" Second, "What are its ethical implications?" Part I addresses the first question by tracing the development of the image of God from Augustine's first extant writings in 386 to his death in 430. Part II demonstrates how Augustine's developing conception of the image of God informs the moral reasoning operative in his ethics.

Part I argues three main points through an exposition of the historical development of image of God throughout Augustine's writings. First, and most basically, Augustine's conception of the image of God changes over the course of his writing career in ways significantly more nuanced and substantial than has been appreciated in previous scholarship. Second, the shifts in Augustine's presentations of the image of God are evident in the alternative ways that he interprets a small number of biblical texts to which he repeatedly returns in advancing particular claims about the image of God. Third, each of seven developments in Augustine's evolving accounts of the image of God can be traced to his interpretation of one or more of this small selection of biblical texts. In short, Augustine's understanding of the image of God changes over time and the developments are justified in large part by his exegesis of specific biblical texts.

Part II argues that the development of the image of God traced in Part I holds explanatory power for interpreting and arbitrating disputes about Augustine's ethics. First, a close reading of De Trinitate 15 shows how Trinitarian and Christological reflection upon the image of God informs the late ethics of lying such that lying becomes the ethical issue par excellence in Augustine's mature conception of the image of God. Second, a chronological examination of earlier expositions of lying manifests other developments in Augustine's ethical thought. I tease out three distinct stages in the moral reasoning about lying that map onto developments observed regarding the image of God. At each stage several comparisons highlight the distinct features of Augustine's ethics of lying at that point in its development - comparisons with his contemporaneous accounts of the image of God, with other ethical issues addressed in his writings, and with the ethic detailed in the other stages. Through this theological, historical, comparative analysis, Part II argues that recognizing developments in Augustine's account of the image of God contributes toward identifying corresponding developments in his ethics. In short, understanding the historical development of the image of God in Augustine's thought is necessary in order to explain features of his ethics that current scholarship elides as well as the ways in which the ethics of lying is (and is not) analogous to the ethics of swearing and coercion. 
From the first days of his conversion to Christianity Augustine had instilled in him a deep and abiding interest in the image of God that would only increase over his forty-five year writing career. ${ }^{1}$ In total, more than five hundred explicit references to the image and likeness of God appear across more than one hundred fifty of Augustine's treatises, sermons, and letters. ${ }^{2}$ Within the confines of this project it is not possible to address all of them, nor would it be desirable to do so. Many are mere allusions of little consequence and, as one would expect, there are many redundancies. ${ }^{3}$ Instead of an exhaustive treatment, I offer an interpretation of the development of Augustine's thought that highlights the emergence of various conceptualizations and distinctions within his innovative and influential expositions of the image of God. This method of presentation

\footnotetext{
${ }^{1}$ Augustine's early interpretation of the image of God and its development are indebted to Ambrose, Origen, Plotinus, Simplicianus, Theodorus, and Marcellus Victorinus, among others. In what respects each has played a role remains of significant interest in Augustine scholarship today as evidenced by the major reassessment of the role of neoPlatonism in Augustine's thought by self-proclaimed "New Canon" of Lewis Ayres, Michel Barnes, Luigi Gioia, Rowan Williams, and others. Assessments of Augustine's indebtedness to the aforementioned figures include J. Heijke, "The Image of God According to Saint Augustine," Studies in the Christian Perpetuation of the Classics (1956): 3-11; H. Somers, "Image de Dieu: Les sources de l'exégèse augustienne" Revue des études augustiniennes 7:2 (1961): 105-125; Gerald A. McCool, "The Ambrosian Origin of St. Augustine's Theology of the Image of God in Man," Theological Studies (1959): 62-81; R.A. Markus, "'Imago' and 'similitudo' in Augustine," Revue des études augustiniennes (1963): 125-143; Gerald Bonner, “Augustine's Doctrine of Man: Image of God and Sinner," Augustinianum 24 (1984): 495-514; Roland J. Teske, "The Image and Likeness of God in St. Augustine's De Genesi ad litteram liber imperfectus," Augustinianum 30:2 (1990): 441-451; Teske, "Origen and St. Augustine's First Commentaries on Genesis," Origeniana Quinta (1992): 179-185; György Heidl, Origen's Influence on the Young Augustine: A Chapter of the History of Origenism (Piscataway, N.J.: Gorgias Press, 2003); Lewis Ayres, Augustine and the Trinity (Cambridge: Cambridge University Press, 2010); Luigi Gioia, The Theological Epistemology of Augustine's De Trinitate (Oxford: Oxford University Press, 2008); and Gerald Boersma, "The Context of Augustine's Early Theology of the Imago Dei” PhD Thesis, Durham University, 2013.

${ }^{2}$ See Appendix A.

${ }^{3}$ Where I treat claims by Augustine about the image of God that are substantiated or corroborated in contemporaneous texts, I provide additional citations in the footnotes.
} 
aims to elucidate Augustine's mature understanding of the image of God-what it is and how it evolves - by attending not only to the increasing specificity Augustine gives to this concept but also to the particular reasons and interesting ways in which his mind changed. $^{4}$

Not long ago scholars could write of Augustine that "it is reasonable to regard his opinions on most theological issues as having been established by the time he became sole bishop of Hippo in 396." Careful attention to Augustine's expositions of biblical

${ }^{4}$ For the dating of Augustine's works, consult the Zentrum für Augustinus-Forschung and the Augustinus-Lexikon, ed. Cornelius Mayer (Basle: Schwabe \& Co., 1986-); James A. Andrews, ed., "List of the Works of Augustine," in The Oxford Guide to the Historical Reception of Augustine, ed. Karla Pollmann (Oxford: Oxford University Press, 2013), xiii-xvi; Allan D. Fitzgerald, Augustine Through the Ages (Grand Rapids, Mich.: Eerdmanns, 2009), xliii-il; William Harmless, Augustine in His Own Words (Washington, DC: Catholic University of America Press, 2010), 441-446; and Serge Lancel, St. Augustine, trans. Antonia Neville (London: SCM Press, 2002), 531-536. Important resources relied upon by each of the above include A.M. La Bonnardière, Reserches de chronologie augustinienne (Paris, 1965), and G. Madec, Introduction aux "Révisions" et à la Lecture des Oeuvres de Saint Augustin, Collection des Éstudes Augustiniennes: Série Antiquitié 150 (Paris: Institut d'Études Augustiniennes, 1996). J. Heijke's critical work on the imago dei in Augustine's writings relies, for dating purposes, primarily upon Zarb, but also Kunzelman (for semons), and Le Landais (for Psalms), all of which pre-date sources relied upon by Fitzgerald and Harmless (see J. Heijke, "St. Augustine's Comments on 'Imago Dei'" Classical Folia, Supplement III [1960]; Seraphinus M. Zarb, "Chronologia operum Sancti Augustini," Angelicum 10:3 [1933]: 359-396; 10:4 [1933]: 478-512; 11:1 [1934]: 78-91; A. Kunzelman, "Die Chronologie der Sermones des hl. Augustinus," Miscellania Agostiniana 2 [1931]: 417-520; Maurice Le Landais, "Deux années de prédication de saint Augustin," Études augustiniennes [1953]: 9-95). The Enarrationes in Psalmos are particularly difficult to date, and the best resource available is the "Enarrationes in Psalmos" entry by Hildegung Müller in the Augustinus-Lexikon (804-838). For Sermons, see Fitzgerald, Augustine Through the Ages (744-789). For De Trinitate, see Lewis Ayres, Augustine and The Trinity (Cambridge: Cambridge University Press, 2010), 118-120, 177-178, and Luigi Gioia, The Theological Epistemology of Augustine's De Trinitate (Oxford: Oxford University Press, 2008), 2 n.4. For De civitate Dei, see also Gerard O'Daly, Augustine's City of God: A Reader's Guide (Oxford: Oxford University Press, 1999), 34-36.

5 Gerald Bonner, "Augustine's Doctrine of Man: Image of God and Sinner," Augustinianum 24 (1984): 495-514, 497. Etienne Gilson makes the claim of basic continuity more strongly, perhaps hyperbolically: "We have never discovered the 
texts demonstrates quite the opposite, at least with respect to his conception of the image

of God. Augustine overturns his own previous teachings regarding the image of God

from 396 to 430 in at least seven respects. In each case, Augustine appeals to one or more

of the nine biblical texts that gradually come to shape his mature conception of the image

of God. $^{6}$

This is not to say that these biblical texts are somehow completely determinative

for Augustine's interpretation of the image of God. It is not as if these texts are agents

acting upon Augustine in a vacuum, absent all other influences or in a deterministic

slightest philosophical change in any of his essential theses. Saint Augustine fixed his main ideas from the time of his conversion-even we believe regarding grace" (Etienne Gilson, The Christian Philosophy of Saint Augustine, trans. L. E. M. Lynch [London: Victor Gallancz, 1960], 364 n.49). Bonner's statement, at least, allows for significant development in Augustine's thought prior to 396, much as Peter Brown and Paula Fredricksen have observed especially in relation to grace and free will. Scholars often point to works produced around 396, especially Ad Simplicianum, to highlight major differences between the understanding of grace, free will, predestination, and meritorious works in De libero arbitrio (393) and Expositio quarundam propositionem ex epistula apostoli ad Romanos (394) as compared to Augustine's later interpretations evident paradigmatically in his anti-Pelagian writings. This scholarly consensus is not without detractors, however. Carol Harrison, for example, argues for extensive continuities between Augustine's earliest writings and his later positions on precisely these issues, advancing the thesis that the so-called "early Augustine" was in fact a short-lived aberration from his otherwise consistent account of grace, free will, and righteous works. See Peter Brown, "The Lost Future," in Augustine of Hippo: A Biography (Berkeley: University of California Press, 2000), 146-157; Carol Harrison, Rethinking Augustine's Early Theology (Oxford: Oxford University Press, 2008); Paula Fredricksen Landes, "Introduction" in Augustine on Romans (Chico, Ca.: Scholar's Press, 1982), ix-xvi. ${ }^{6}$ See Appendix B. The nine biblical texts to which Augustine gives considerable attention in his numerous expositions of the image of God are Gen 1.26-27; Rom 8.29; 1 Cor 11.7, 15.49; 2 Cor 3.18, 4.16; Eph 4.23-24; Col 3.9-10; and 1 Jn 3.2. The one text in which Augustine cites all nine is De Trinitate. Eight are cited in a short discussion at the end of Book 14 in which Augustine locates each of these verses as they pertain to a particular facet of the image of God. Biblical texts that occur with less frequency in his discussions of the image of God include Ps 39.6; Matt 22.20ff / Mk 12.16ff / Lk 20.24ff; Rom 1.23, 12.2; and 1 Cor 13.12. Other biblical texts of historical importance to expositions of the image of God, but to which Augustine gives little or no attention in his expositions, include Gen 5.1-3; Gen 9.6; Ps 8; Sir 17.1-3; 2 Esd 8.44; Col 1.15; 2 Cor 4.4; Heb 1.3; and Jas 3.9. 
fashion. Rather, they offer something like the ready-to-hand metaphors, distinctions, and grammar that Augustine eagerly engages in resolute reading practices and takes up for his particular purposes. Embedded within a tumultuous Roman North-African cultural moment and educated in the Latin literary and philosophical tradition, Augustine approaches these texts with great care even as his thought and writings are influenced and impacted by countless other spoken and unspoken concerns. He attends to them, in some ways, as he had many others before, as a capable rhetor always in dialogue with his audience as much as his philosophical inheritance, a man with sophisticated hermeneutic faculties operative within often tacit metaphysical frameworks. As his scriptures increasingly capture his attention and imagination, he perceives them as a divine-gift imbued with complexity and providential obscurities. Karl Jaspers rightly observes, "The Bible is [for Augustine] the sole source of essential truth."7 That this truth is hard won, writes Augustine, "is all due, I have no doubt at all, to divine providence, in order to break in pride with hard labor, and to save the intelligence from boredom." ${ }^{\text {A }}$ Augustine never bored of piecing together biblical texts that refer to the image of God.

Part I of this project charts the historical development of the image of God in Augustine's writings. Part II overlays this interpretive foundation with additional, related developments in the ethical implications of the image of God, demonstrating the utility and explanatory power of the historical development method for interpreting Augustine.

In the first six sections of Part I, I trace strands of the development of Augustine's thought across six periods. Section I.1 (386-388) considers the backdrop or canvas of

\footnotetext{
${ }^{7}$ Karl Jaspers, The Great Philosophers: The Foundations, ed. Hannah Arendt, trans. R. Mannheim (New York: Harcourt, Brace \& World, 1962), 186.

${ }^{8}$ doctr. Chr. 2.6.7.
} 
Augustine's earliest philosophical writings upon which his picture of the image of God begins to emerge, including discussions of the rational soul, types of images, the great questions of philosophy, and his very first reference to the image of God. Section I.2 (388-390) finds Augustine offering a spiritual reading of Genesis in order to respond to his Manichean heritage and their denigration of the Old Testament, including the contention that it teaches human beings are created in the image of God with respect to the body. Section I.3 (391-395) considers the writings of Augustine while a priest, including a second exposition of Genesis that keys on the second person of the Trinity about the image and likeness of God, through whom and to whom the human is created. The human is created to the image and likeness of God (ad imaginem et similitudinem) whereas the Son of God is the image of God (est imago dei). Section I.4 (396-400) marks the beginning of Augustine's tenure as a bishop as well as the first retractions of previous claims regarding the image of God. Confessiones marks a major pivot in Augustine's thinking about the image of God, not only as it narrates the Manichean teachings that Augustine had come to reject, but also revising the interpretation of Gen 1.26-27 in his first Genesis commentary written to refute Manichean errors. For the first time, the image of God of Genesis 1.26 is taken to refer to an image of the Trinity evident in the human being, displacing for a time the conception of the Son as the perfect image and likeness of God, in whose perfections human beings participate. Section I.5 (401-412) teases out Augustine's shifting understanding of key scriptural texts in De opere monachorum, De Genesi ad litteram, and De spiritu et littera. In this generative period Augustine identifies two functions of the human mind - active knowing and contemplating wisdomassociating the image of God only with the latter, and he reverses his position regarding 
whether the image of God is lost in the Fall. Section I.6 (413-426) presents Augustine's mature exposition of the image of God, observing how the exposition in De Trinitate 14 weaves together basic theological commitments with scriptural metaphors, modifies earlier intuitions, and produces an intricate tapestry of both novel and long-enduring, interrelated strands. Section I.7 considers Augustine's final references to the image of the Son in light of the two cities metaphor and the role played by two biblical texts which refer to the image of the Son. With the various conceptualizations from across his corpus in view, Section I.8 (396-430) retraces seven developments in Augustine's understanding of the image of God and examines how his incorporation of various biblical texts and motifs shapes his mature accounts of the image of the Trinity in the rational soul and of the resurrected body's immortality as the image of the Son.

The historicized account of "Augustine on the image of God" that emerges in the course of Part I is brought to bear on Augustine's ethics in Part II. Section II.1 examines how the account of the image of God from Part I might contribute to ongoing debates about Augustine's ethics of coercion, lying, and killing, as well as broader discourses in which the image of God is invoked today. Section II.2 argues that De Trinitate 15 affords a unique vantage from which to assess Augustine's understanding of the image of God for an issue whose centrality to moral and political theology is distinctly Augustiniannamely, lying. Within a Trinitarian and Christological grammar, Augustine explores lying in relation to two words generated within the human mind that are analogous to the generation of the second person of the Trinity and to the incarnations of the Word. Furthermore, the potential for ignorance, errors, and lies in the post-Fall rational soul indexes the divine perfections of omniscience, simplicity, and omnipotence in ways that 
helpfully illuminate why it is that "necessity" justifies so many otherwise objectionable acts in Augustine's ethics but never lying. The prominence given to lying in De Trinitate 15's final exposition of the image of God, is a late development in Augustine's ethics that provides a useful backdrop against which earlier presentations of Augustine's ethics are brought into relief. Section II.3 traces Augustine's use of one particular biblical text. "Let your speech be 'Yes, yes; no, no"' (Mt 5.37) is unique in comparison to more than a hundred other biblical narratives, metaphors, and texts in that Augustine draws upon the “yes, yes; no, no" refrain more frequently and more consistently than any other biblical text throughout his writings on lying. Consistently, Augustine affirms that lying is always a sin and thus prohibited, and yet the moral framework or reasoning through which Augustine evaluates various cases of lying depends upon and develops in ways that are analogous to contemporaneous accounts of the image of God. Matthew 5.37 serves as a red thread that helpfully draws attention to modifications in Augustine's ethic of lying from its earliest framing as a perfection of virtue, to its later formulation as a command recognized by the regenerate, and, finally, to its internalization within the imago trinitatis. Section II.4 argues that Augustine's ethic is consistent in its prohibition of lying but that the moral reasoning that frames this judgment exhibits gradual modification of the "yes, yes; no, no" in three stages. Developments from his earliest to his latest ethics of lying provide an ethical analogue to contemporaneous formulations of Augustine's understanding of the image of God. The greatest novelty in the development of Augustine's ethics of lying is his combining Trinitarian, Christological, anthropological, and ethical reflection to generate an interpretation that identifies lying as the origin of every sin conceived in the rational soul. 
In the beginning of evil was the lie

The question of lying gets at the very core of Augustine's doctrines of God, the Trinity, Christology, and humanity. There is no moral issue more intimately tied to these doctrinal loci than that of lying. The reasons for this have to do with his account of the act of lying and the way it draws upon the twin functions of the image of Trinity in the mind. Killing, torture, coercive violence - these acts involve natural evils, human acts of violence that both result from and are necessitated by original and inherited sin. They are lamentable and miserable but they are sometimes necessary — which is to say that they are not moral evils in and of themselves. For Augustine, it is lying, not violence, that is the fundamental moral evil. In his mature theology and ethics, lying is the fundamental act by which the will turns its desire to things created rather than their Creator. It is the original sin of Lucifer, the Father of Lies, and it is the original sin of the human. In each of these firsts, the will went wrong by lying. And ever since, it has been the sin of lying that has been at the root of every other sinful work. It is the origin of the schism between the heavenly and earthly cities and it is the essential, enduring feature of the latter. The lie is the original evil that gives rise to all other evils. In the beginning of evil was the lie.

Lying is the original sin and is at the origin of every subsequent sin. If we are to understand Augustine's ethics we will have to attend to the meaning he gives to lyingthe reasons that he views it as the primal evil act and the source of every sin in human history. Of course, we will also want to consider its implications for political existence amidst the two entangled cities and the necessities of their life together in the saeculum. In order to understand how Christians ought to engage in civic life during the shared journey of the two cities, Augustine thinks we will need to consider the lies of the 
demons before the creation of the human. ${ }^{9}$ It is not sufficient to begin an inquiry into Augustine's political theology at De civitate Dei 19 if the aim is to understand the commitments and motivations that form its descriptions and prescriptions offered so late in Augustine's oeuvre in general and in De civitate Dei in particular. The political theology of Book 19 can no more be understood apart from Augustine's theoanthropology than it can apart from the contemporaneous polemics against the Pelagians.

As James Wetzel observes, Augustine identifies lying as foundational to the terrena civitas and thus fundamental to understanding the permixtum, saeculi civitatis.

Each of the two cities, then, is a mixed bag of natures, fleshy and fleshless, but a distinctive unity of will. Angels and saints in chorus will the good for God's sake; demons and their human minions work publicly for worldly glory, while privately serving the good of their separate and endlessly dissipating selves, for theirs is the unity of a common lie. Opposing orientations of will, one true, the other false, is what counts for Augustine as the defining difference between two mixed-natured cities, both angelic and human, but as different as day and night. ${ }^{10}$

It is an orientation of the will on which turns the true or false nature of one's eschatological residence. The opposition of the two cities begins with the lie held in common by the reprobate and the Father of Lies. And it is that primal lie that eventuates in the evils that equally afflict the citizens of both cities in the saeculum, the evils and sufferings they hold in common.

Given the prominent role played by lying in Augustine's theological and moral imaginary, the descriptive accounts of Augustine on the image of God and ethics in Part II will give particular attention to lying. The purpose here is not so much to advocate or defend Augustine's conclusions regarding lying as to understand the various forms of

\footnotetext{
${ }^{9}$ See civ. 11.13-15.

${ }^{10}$ James Wetzel, "Saint Augustine Lecture 2012: A Tangle of Two Cities," Augustinian Studies 43:1/2 (2012): 12.
} 
moral reasoning that inform his conclusions regarding the relative morality of particular lies and of lying in relation to other objectionable acts. Specifically, we will examine when, whether, and how Augustine's understanding of the image of God is or is not operative in his moral reasoning about lying.

The history and method of the project

This is not the project I set out to pursue. The account of the development of Augustine's thought pursued in Part I, "Augustine on the Image of God," was not the original plan but a "necessity" (in one sense Augustine gives this term) in order to coherently account for Augustine's diverse proposals over time regarding several distinct facets of the image of God. ${ }^{11}$ One effect of historicizing Augustine's understanding of the image of God is the attention drawn to Augustine's biblical exegesis of a handful of particular texts precisely where he presents his reasons for advancing or retracting different possible conceptions of the image of God metaphor. Thus, Augustine's use of scripture features far more prominently in both Part I and Part II than I imagined when I began my research. Furthermore, I resisted nearly to the end allowing the ethics of lying to take a place of such prominence in Part II, "Ethics After the Image of God." My sense was that this territory of Augustine's ethics had been covered sufficiently, and my own interests in the image of God and human dignity made lying less appealing as an issue of ethical reflection than issues of coercion, both religious and political. Here, however, the decision to follow the ethical implications of the image of God as Augustine explicates them in his own writings proved determinative. Among the benefits of following

\footnotetext{
${ }^{11}$ We will return to the varieties of "necessity" in Augustine's ethics in Part II.
} 
Augustine's lead are the sorts of interventions that I offer in the contest of interpretations regarding Augustine's ethics of lying-including specific features of his definition of lying (e.g., voluntate fallendi), the role of necessity in his moral reasoning, as well as the debates about how lying relates to other issues in his ethics such as killing and coercion.

This project's methodological decisions regarding Augustine's development, attention to biblical expositions, and exposition of the framework of his moral reasoning, combine to generate a picture of Augustine as a biblical theologian in via, one committed to biblical exposition but in a way that renders earlier judgments always provisional. ${ }^{12}$ In the conclusion we will return to the questions of what all of this might mean if we are to provide an "Augustinian" interpretation of the image of God for today. First, however, a bit more about how the project took shape.

The dissertation I proposed was a study of the imago dei in the theology and ethics of Augustine and Karl Barth. I intended a comparison of how theological anthropology informs moral reasoning in different figures. I had hoped to examine and compare Augustine's and Barth's distinct conceptions of the image of God and how these interpretations give rise to distinct judgments in issues of practical ethics as compared to modern invocations of human dignity. Thus, I began Part I with the expectation of a quick reading of the references to the imago dei across Augustine's writings that would allow me to de-center the account of the image of God in De Trinitate so often privileged in the vast secondary literature on Augustine's imago Dei. ${ }^{13}$ It quickly became apparent,

\footnotetext{
${ }^{12}$ Augustine presents his understanding of the dialectical nature of the study of scripture in De Doctrina Christiana.

${ }^{13}$ Lewis Ayres argues, for example, that De Trinitate has been unduly privileged in interpreting Augustine's thought on the image of God, especially its analogy of memory, intellect, and will for the Trinity. His preference to "slightly de-centre Books 8-15 of the
} 
however, that much more was going on in Augustine's usage of the image of God than either the secondary literature or a summary of my cursory reading could provide. Telling the story of how Augustine employs this term across the more than 500 references that I catalogued — three times what I had expected based on the best secondary scholarship ${ }^{14}$ could easily have been a dissertation in its own right. Over the course of several months, Part I of this dissertation took shape quite differently than I had foreseen.

Perhaps the most surprising element of how the project took shape was the way in which Augustine's use of biblical texts emerged as an essential component in accounting for how the meaning given to the image of God term evolves over time. I had not anticipated that these texts would be so prominent in Augustine's expositions of the image of God or that he would appeal to them as warrants when advancing new readings. The relatively few references to biblical texts in secondary literature interpreting Augustine on the image of God did not prepare me for what I found. I certainly had not expected Augustine would return so often to the same biblical texts while at the same time remaining completely silent regarding other texts that are so important to alternative,

De Trinitate as a source of his mature Trinitarian theology," based an assessment that, "We have no reason not to take the discussion of the De civitate Dei 11 as offering the wider context within which De Trinitate 9 and 10 occurs." Ayres, Augustine and the Trinity (Cambridge: Cambridge University Press, 2012), 317-318. Any survey of the secondary literature confirms the privileged status of De Trinitate 14, but this does not in itself prove that this place of prominence is undue or unwarranted. To assess that argument, we will have to consider how De Trinitate 14 relates to other sources within Augustine's writings on the image of God.

${ }^{14}$ See J. Heijke, "St. Augustine's Comments on 'Imago Dei." 'Heijke's collection of 142 references is a standard reference for scholarship on the imago dei in Augustine's thought. See also, J. Heijke, "The Image of God According to St. Augustine." Part I provides a more thorough examination of more than five hundred references to the image of God collected in Appendix A. 
competing interpretations of the imago dei prominent in both late-antiquity and modernity.

In the conclusion, and occasionally in the footnotes, I will return to the question of how to assess Augustine's silence regarding certain biblical texts historically important to interpretations of the image of God. For now, it is important to keep in mind the fluidity of the vetus latina biblical materials with which Augustine works. Augustine does not have in front of him one Latin biblical translation or text but many, and when he first encounters versions of Jerome's Vulgate he is not at all happy that Jerome is translating to Latin directly from Hebrew texts rather than from the Septuagint. ${ }^{15}$ Augustine does not have a compendium of all of the references to the "imago dei" in the Latin biblical sources, far less the Hebrew or Greek uses of tselem and demuth or eikon and homoiōsin. Thus, it is worth noting at the outset, and it may come as a surprise to many, that Augustine's most common phrase for speaking of the image of God with respect to human beings is not that they are the imago dei. ${ }^{16} \mathrm{He}$ would not come to assert that human beings are the image of God until 401 in De opere monachorum. During the first third of his writing career, Augustine consistently asserts, as had Ambrose and the Alexandrians before him, that the Son of God, the second person of the Trinity, is the image of God.

Given this initial tendency to identify the Son as the image of God, it may also be somewhat of a surprise to discover that among the hundreds of references to the image

15 Augustine is more interested in "unity" than a Latin translation more faithful to the Hebrew. He would prefer Jerome and others translate the miraculously generated Greek Septuagint than from Hebrew texts (See Epp. 28, 71, and 82, and doct. Chr. 2.15.22). ${ }^{16}$ Far more often than imago dei in the nominative, Augustine employs the term $a d$ imaginem [et similitudinem] dei in which the ad plus accusative construction functions as a dative. 
and likeness of God the two scriptural texts that straightforwardly equate the image of God with the Son-Col 1.15 and 2 Cor 4.4 —are never discussed by Augustine. These are also the only two biblical texts in which the precise term "imago dei" occurs in the Latin. ${ }^{17}$ Other biblical references to the image of God do not use this formulation, but a variety of other constructions, all of which Augustine incorporates with great frequency in developing his theological anthropology.

With these factors in view, it will perhaps be more understandable that we find Augustine's conception of the image of God developing so considerably over his career as he gradually incorporates various scriptural texts into his understanding, adjusting his framework to the texts and the interpretations he generates as he goes. Where he takes his interpretation to be contested or contestable, he regularly offers reasons explaining why his determination is superior to his interlocutors'-mostly real ones but also, at times, imagined - including his own previous conceptualizations. As his understanding of the image of God develops, primarily between 396 and 426, most often the warrants he provides for his claims come in the form of scriptural quotations, themes, and metaphors.

How to read Augustine on the image of God

As questions about the meaning and ethical implications of the image of God in Augustine are raised and addressed, several related issues predictably arise: How does the understanding of Augustine that emerges from this study compare to other scholarly presentations? What methods are best suited to interpreting this particular figure? Which

\footnotetext{
${ }^{17}$ This is true of the Vulgate and, it would seem, the vetus latina as well. The more than seventy uses of the phrase "imago dei" in Augustine's writings never suggest that this phrase derives from a biblical quotation.
} 
features of his moral reasoning warrant greater critical scrutiny and attention by those who embrace the moniker "Augustinian" today? In short, how are we to read Augustine, and why does it matter?

Scholars read Augustine for diverse purposes and utilize different methods depending on disciplinary homes and motivating questions. Historical theologians whose research focuses on early Christianity, for example, give particular attention to Augustine's departures from and modifications of his "pro-Nicene" and "late-antique" interlocutors and their theological and philosophical forebearers. ${ }^{18}$ Other historical theologians more interested in later periods read Augustine primarily as an influential font of subsequent debates on a range of theological and moral topics. ${ }^{19}$ Philosophical theologians, more concerned with arguments than historical antecedents or later influence, predictably give greater attention to treatises on the will and predestination, discussions of time and eternity, or the nature of God, the human, or evil. Scholars interested in political theology read Augustine's texts for their descriptions of love, power, and persuasion in the polis as he encounters threats to the flourishing of the commonwealth in the saeculum. ${ }^{20}$ Christian ethicists, more than historical, philosophical,

${ }^{18}$ See John Rist, Augustine: Ancient Thought Baptized (Cambridge: Cambridge University Press, 1994); Roland J. Teske, S.J., To Know God and the Soul: Essays on the Thought of Saint Augustine (Washington, D.C.: Catholic University of America Press, 2008); Luigi Gioia, The Theological Epistemology of Augustine's De Trinitate; and Lewis Ayres, Augustine and the Trinity.

${ }^{19}$ See John Burnaby, Amor Dei: A Study of the Religion of St. Augustine (London: Hodder \& Stoughton, 1938); John Edward Sullivan, O.P., The Image of God: The Doctrine of St. Augustine and Its Influence (Dubuque: The Priority Press, 1963); and Jennifer Herdt, Putting On Virtue: The Legacy of the Splendid Vices (Chicago: University of Chicago Press, 2008).

${ }^{20}$ See R.A. Markus, Saeculum: History and Society in the Theology of Augustine (Cambridge: Cambridge University Press, 1970); John Milbank, Theology and Social Theory: Beyond Secular Reason (Oxford: Blackwell Publishers Inc., 1990); John von 
and political theologians, read Augustine to understand his moral reasoning about practical issues of war and wealth, violence and necessity, sexuality and marriage, the goods of this life and the virtues in relation to the next. ${ }^{21}$

This dissertation self-consciously draws upon all of the above approaches. Yet the picture of Augustine that emerges, with implications for what it might mean to be "Augustinian," is one of a scholar, priest, and bishop best described as a biblical theologian who is always reforming or, to be a bit more precise, a Church-theologian who is always being reformed by, among other practices, his exegetical reading of Scripture. ${ }^{22}$

Such a picture both addresses but also problematizes this project's motivating question-"What is the image of God for Augustine?"- by suggesting a slightly different approach than those already mentioned. The problem with this question, as it is posed, is that it implies a single answer whereas Augustine's texts admit several different, mutually exclusive responses. That is, like most people, Augustine changes his mind about numerous questions over time, and this is particularly true of the image of God metaphor. For this reason, answering the question of what the image of God means for Augustine requires that we specify our inquiry: whose Augustine, which writings, and, most important, in what period of his life? Interpreting Augustine's understanding of the

Heyking, Augustine and Politics as Longing in the World (Columbia, Mo.: University of Missouri Press, 2001); and Eric Gregory, the Politics and the Order of Love (Chicago: University of Chicago, 2008).

${ }^{21}$ Paul J. Griffiths, Lying: An Augustinian Theology of Duplicity (Grand Rapids: Brazos Press, 2004); William S. Babcock, The Ethics of St. Augustine (Atlanta: Scholars Press, 1991); and Judith Chelius Stark, ed., Feminist Interpretations of Augustine (University Park, Penn.: Pennsylvania State University Press, 2007).

${ }^{22}$ On the idea of "reform" in Augustine's thought, see Gerhart B. Ladner, The Idea of Reform: Its Impact on Christian Thought and Action in the Age of the Fathers (Cambridge, Mass.: Harvard University Press, 1959), esp. 153-283. 
image of God demands this sort of specificity due, in large part, to the sorts of practices in which he was steeped and the material conditions that informed his everyday life.

The manner in which Augustine's understanding of the image of God develops is closely connected to re-readings and exegesis of biblical texts. The vast majority of Augustine's voluminous oeuvre consists of expositions of scripture and sermons. Those writings that are of other genres are, for the most part, littered with conclusions arrived at within his more biblically-focused writings, whether the genre of these other writings is philosophical, moral, theological, epistolary, or polemical (against Manichees, Donatists, Pelagians, Arians, and other non-Catholic groups). Particularly after 388, and even more so after his ordination as a priest in 391 , the proportion of time and attention dedicated to sermons, homilies, expositions, and collections of propositions drawn from Old Testament, Apocrypha, and New Testament texts across Augustine's writings manifests the degree to which these texts eclipse other authoritative influences. Nothing comparable exists for other subject matters. In the vast majority of his writings, insofar as he articulates his reasons and shares them with others, the authoritative sources that he expects will prove persuasive to his interlocutors are drawn from those texts that function for him as Scripture. As we will see, this is not mere rhetoric for Augustine, but the manifestation of a practice in which he is steeped and in which he hopes the reader will participate. We will have to return to the question of what might happen to Augustine's later understanding of the image of God were he to have similarly engaged other biblical texts. But first we will have to see what the image of God came to mean to Augustine. 
I.1 Before Genesis: The image of God and the rational soul (386-388)

Major contours and basic elements of Augustine's mature expositions of the image of God find expression already in the very earliest of his extant writings. Although Augustine never mentions the image of God in them, already in 386 his philosophical treatises - Contra Academicos, De beata vita, and De ordine - present an understanding of the human soul and the distinction between the intelligible world and sensible world that remain foundational to Augustine's subsequent teachings about the image of God. These dialogues from Augustine's short-lived "cultured retirement" to Cassiciacum reflect the past of Augustine's literary training and the proficiencies honed en route to becoming a professor of rhetoric in Milan. They also evidence an optimistic moral seriousness, the enthusiasm of a convert from Manicheism to Christianity who had seen the light, who had endured months as a competens at the feet of the imposing bishop of Milan, Ambrose, and who was shortly to undergo catechesis and a highly-ritualized and mysterious sacrament of baptism.

During this period of intellectual retreat and anticipation, only months after his conversion to Catholic Christianity at the age of thirty-two, Augustine writes in De beata vita (386) of the human soul's non-corporeal likeness to God, channeling Ambrose in arguing that "of all things the soul is nearest to God." The teaching that there is nothing nearer to God than the human soul — that in the chain of being there is no nature higher than the human soul, no nature between the human soul and God—was to remain a basic tenet of the anthropology informing Augustine's practical moral teachings.

\footnotetext{
${ }^{1}$ beata $v .1 .1 .4$.
} 
Only a few months later, Augustine concludes Contra Academicos (386) with what looking back over his oeuvre might be seen as the scaffoldings of a metaphysical framework, a hermeneutics, and an ambitious if nascent research program that would manifest variously in future works. Here, Augustine advocates six of Plato's theories, the first three of which are:

that there are two worlds - an intelligible world in which the truth itself resides, and this sensible world which it is manifest that we perceive by sight and touch; that consequently the former is a true world, and the present world is truth-like-made unto the image of the other; that the truth emanates from the intelligible world, and is, as it were, refined and brightened in the soul which knows itself. ${ }^{2}$

The image of God will later be explored in relation to each of these distinctions - it is intelligible rather than sensible; it is the creaturely, or made, truth-like image of the God who is Truth itself; and God, as Truth, is known through the light with which the rational soul comes to know itself as the image of God. The closing sentences of the discourse anticipate additional major emphases in later writings on the image of God.

With all the zeal of a recent convert and with an optimism that would later wane in some respects, Augustine here resolves to pursue wisdom with all of his abilities and without departing from the authority of Christ:

And now - that you may grasp my whole meaning in a few words - whatever may be the nature of human wisdom, I see that I have not yet understood it. Nevertheless, although I am now in the thirty-third year of my life, I do not think that I ought to despair of understanding it some day, for I have resolved to disregard all the other things which mortals consider good, and to devote myself to an investigation of it. ... we are impelled toward knowledge by a twofold force: the force of authority and the force of reason. And I am resolved never to deviate in the least from the authority of Christ, for I find none more powerful. But as to what is attainable by acute and accurate reasoning, such is my state of mind that I am impatient to grasp what truth is - to grasp it not only by belief, but also by

\footnotetext{
${ }^{2}$ Acad. 3.17.37.
} 
comprehension. Meanwhile, I am confident that I shall find among the Platonists what is not in opposition to our Sacred Scriptures. ${ }^{3}$

A resolute desire and anticipatory hope to understand wisdom—not merely in part or only by faith but comprehensively and through reason - animate Augustine from the start. His confidence both in a congruence between Platonists and his scriptures and in an agreement between reason and faith will be tested in significant ways, though more often than not harmonious resolutions are found. ${ }^{4}$ As we will see, which of these sources and methods are operative in Augustine's thought often remains implicit. Particularly in these early writings, Augustine prefers not to appeal to scripture where the Platonists and natural reason suffice for his purposes, whereas in later years biblical texts feature far more prominently and frequently than any other authoritative sources.

Augustine's third philosophical treatise from the 386-387 winter in Cassiacum, De ordine, contends that human beings are rational, mortal animals, where reason is defined as "a mental operation with the power to distinguish between, and to connect, things we learn." As rational and mortal, the human being is distinguished from God in its mortality and from all other animals in its capacity for knowledge of God and of its own soul. ${ }^{6}$ Although the human being considered as a whole is mortal, reason itself is immortal, and therefore the reasoning capacity of the soul evidences the soul's immortality: "the soul is none other than reason, which I use and which makes me a superior being, this binds me to become ever better, up to immortality itself." The ascent

3 Acad. 3.20.43.

${ }^{4}$ Augustine would subsequently qualify such statements, but he continues to uphold, in general, an agreement between what one can know through natural reason and that which scripture attests. See, for example, conf. 7.9.13-10.15; Trin. 15.1.1.

5 ord. 2.11.30.

6 "Nothing more than rationality keeps me above the brutes" (ord. 2.19.49; see also 2.11.31). 
of the soul enacts a gradual progression guided by reason's binding itself to immortal truth.

Augustine alludes to the image of God for the first time in his last work from the productive months spent in Cassiciacum. Soliloquia (386/387) reflects upon the image of God amidst discussions relating love, the role of similitude in lying, and the rational soul's need for healing — three features that are intimately interrelated in Augustine's mature account of the image of God. Augustine's first reference to Gen 1.26 and the image of God reads: "O God, who hast made man to your image and likeness, a fact which he acknowledges who knows himself."7 This reference to the image of God occurs in an address to God and does little theoretical work. However, that Augustine weds the image of God to the Delphic maxim so esteemed by Plato certainly indicates a particular gravity, even if the context offers little that explicitly identifies in what specific respect human beings bear this honorable epithet.

Soliloquia introduces love as a concept intimately related to the rational soul that the earlier treatises identify as that which is highest in the human. The degree of one's love for one's friends is properly greater "the better use they make of their rational souls. ${ }^{8}$ Furthermore, it is the proper use of the rational soul that brings about the healing of the soul's corruption. The conditions of the soul being healed include that it must have a capacity, it must enact or actualize that capacity, and it must do so upon the proper object. In order for the rational soul to find healing, the reason (which is analogous to the eyes of the soul) must have the capacity for seeing God; it must do so with faith, hope,

\footnotetext{
${ }^{7}$ sol. 1.1.4.

8 sol. 1.2.7.
} 
and love; and it must direct its gaze to God as the object of contemplation. ${ }^{9}$ Augustine's observation that similitude or resemblance, a likeness of a certain sort, is "the mother of falsity" also prefigures later moral reasoning regarding lying and the relationship of the image of God to the mind's generation of true words. ${ }^{10}$ Even as it introduces these themes that would grow to be quite prominent in later discourse on the image of God, Soliloquia does little in the way of prefiguring how the several strands will be woven together or what their particular relationship is to the image of God term in particular.

Shortly after his return to Milan and his baptism in the spring of 387, Augustine returns to the question of the soul's immortality. De immortalitate animae argues that the reasons for believing in the soul's immortality might be based upon either natural reason or scripture. Again, in this early writing, Augustine treats the question specifically from what he takes to be a philosophical perspective that employs natural reason, avoiding arguments based upon scripture or creeds and without mentioning Christ. He maintains that knowledge of God and the soul are the only two worthwhile questions in philosophy. Both questions will become essential to and interwoven in his later discussions of the image of God-nowhere more so than in De Trinitate. That references to the image of God are absent from this early philosophical text is understandable given Augustine's stated purpose of proving by rational argument that the soul is an incorporeal, immortal substance. As in De ordine and Soliloquia, Augustine argues that the soul is that part of the body in which immortal truth resides, again concluding that it too must be immortal.

Augustine further develops his argument for the soul's immortality in De animae quantitate. This text was written in Rome in 388 following the vision in Ostia famously

\footnotetext{
${ }^{9}$ See sol. 1.6.12.

${ }^{10}$ sol. 2.6.10.
} 
recounted in Confessiones and shortly after the death of his beloved mother Monica. It is written as dialogue, much like those from Cassiciacum, and in it Augustine contends that the soul is not like the body that is made up of the four elements of earth, air, fire, and water but is a substance of its own. ${ }^{11}$ The soul's substance differs from the divine substance, but it "is like to God" in being a non-material substance. Precisely in what respect it is "like" God is given somewhat limited specificity later in the dialogue. Augustine has Evodius voice the conviction that the human soul ought to be capable of making things that are immortal if, after all, God made the soul with an immortal nature in the likeness of God who made it. Augustine counters, "your soul has not the same power as He in whose likeness it has been made."12 The likeness of the soul to God does not imply that it shares the divine nature or all of its powers. ${ }^{13}$ Because it lacks God's powers, the soul, although immortal itself, cannot of itself produce anything immortal. From this dialogue it might be inferred that immortality constitutes the soul's likeness to God, but the evidence for this conclusion is, as yet, implicit or circumstantial. ${ }^{14}$

What the soul can and should do - and this Augustine learns from "the liturgy of the Church"- - is to mortify its desires for all bodily things of the world, thereby reforming itself with the help God mercifully provides:

whoever would restore himself to the condition of man as created by God, namely, to the likeness of God, must despise all corporeal things and renounce the entire world, which we see is corporeal, for that is the only way of accomplishing the soul's salvation, or of renovation, or reconciliation with its maker. ${ }^{15}$

This bit of liturgical theology associates "to the likeness of God" with "to the condition

${ }^{11}$ See also conf. 4.3.4.

12 an. quant. 1.2.3.

${ }^{13}$ See also conf. 7.1.1.

${ }^{14}$ A similar conclusion might be drawn from $s .375 \mathrm{~B}$.

${ }^{15}$ an. quant. 1.3.4. 
of man as created by God," and yet it refrains from identifying particular attributes of that human condition. Ambiguity remains insofar as neither the soul itself nor any feature of the soul is identified as the image or likeness of God, with the possible exception of the (non-)attribute of non-corporeality. Although the rational soul plays a crucial role in restoring the human to the desired renovated state, it is not yet identified as that which constitutes the image of God. A much later digression does specify that the rational soul both distinguishes human beings from the brute animals and that the rational soul is the agent of the needed renovation. ${ }^{16}$ Augustine writes,

the soul should not pour itself out in the senses beyond the measure of necessity, but rather should recall itself from the senses and become a child of God again, that is, be made a new man by putting off the old. There is surely need to begin at the reformation ... This renovation cannot take place at all, unless we are remade in the image of Him who gave us that image to keep as a most precious treasure, when he gave us to ourselves with such a nature that only He Himself can rank above us. ... the soul has not the strength to begin or complete it, except with the help of him to whom it turns itself. Hence it comes about that man's reformation must be sought from the mercy of Him whose goodness and power are the cause of man's formation. ${ }^{17}$

Six features of this quotation that take on increasing importance in Augustine's later writings warrant comment.

First, it is clear here that the soul is the primary actor in pursuing renovation to the image of God. Second, Augustine invokes metaphors from Col 3 and Eph 4 to portray the reformation of God's image. Col 3.9b-10 reads,

Put off the old human with its actions and put on the new human that is being renovated in the recognition of God in accordance with the image of

\footnotetext{
${ }^{16}$ That "every man is a rational animal subject to death" distinguishes human beings from "brute beasts" (an. quant. 28.54).

17 an. quant. 28.55 .
} 
the one who created it. ${ }^{18}$

Augustine often quotes Eph 4.23-24 alongside Col 3.9b-10 as a parallel passage.

Beginning with verse 21, Eph 4 reads,

As the truth is in Jesus, you are to put off, in line with your previous habits, your old human, the one who is being corrupted in accordance with deceitful desires, but be renewed in the spirit of your minds, put on the new human, the one who in accordance with God, was created in righteousness and true holiness. ${ }^{19}$

De animae quantitate is Augustine's first allusion to the Col 3 and Eph 4 metaphor of putting off [deponere/ expoliantes/spoliantes/ exspoliantes] the old and clothing oneself [induite] with the new, a metaphor that will become central to his understanding of the image of God. Here the metaphor functions quite differently than it will in his later writings. In this instance — a third notable feature of this passage - the renovation or reformation of the old human into the new human is conditioned upon already having been "remade" into the image of God by the Creator who formed human beings in this image in the first place. After their formation human beings failed in the task of keeping

${ }^{18}$ In an. quant. Augustine does not quote Col 3.9b-10 or Eph 4.22-24 at length, but only invokes the metaphor of the old and new human on which they trade. Here I translate Col 3.9b-10 as it appears in c. Adim. 5.2 (394) where Augustine first quotes the relevant passage-expoliantes uos veterem hominem cum actibus eius induite nouum, qui renovatur in agnitionem dei secundum imaginem eius, qui creavit eum.

${ }^{19}$ This translation of Eph 4.24 derives from op. mon. 32.20 (401) where Augustine first quotes the relevant passage-sicut est veritas in iesu, deponere uos secundum priorem conuersationem ueterem hominem, eum qui corrumpitur secundum concupiscentias deceptionis, renouamini autem spiritu mentis uestrae et induite nouum hominem, eum qui secundum deum creatus est - as well as from the second time Augustine quotes the verse at length, in Gn. litt. 26.37, where the text reads identically but includes the closing phrase, in iustitia et sanctitate ueritatis. This clause would become important not only for Augustine but for many subsequent interpretations of the image of God. Quite often, Augustine harmonizes elements of the two passages, as in Gn. litt. 20.30- "Be renewed in the spirit of your minds and put on the new human (Eph 4.24), who is being renewed for the recognition of God according to the image of the one who created it (Col 3.10)" renouamini in spiritu mentis uestrae et induite nouum hominem, qui renouatur in agnitionem dei secundum imaginem eius, qui creauit eum. 
this image intact - the image of God was lost. Twenty-five years later, in 412, Augustine would entertain for the first time the possibility that the image of God may not have been lost in the Fall. ${ }^{20}$ Fourth, the claim that only God is higher than the human soul is reiterated. Fifth, the renovation begun by God's restoring human beings to the divine image is not itself the renewal but only the beginning of a much longer process of renewing.

One final element of De animae quantitate bears mentioning - the role of memory in measuring the soul's magnitude. The soul's memory is itself incorporeal and, although in the body, capable of containing many much larger incorporeal bodies such as its knowledge of multiple spatially expansive cities. Not only would this example become one of Augustine's favorites - here, the city chosen is Milan, but elsewhere it is Carthage, Hippo, or Rome — but it highlights the element of memory as a distinctive feature of Augustine's thinking about the soul. It is not the case that Augustine introduces memory as a third element of the soul in De Trinitate in order to establish a vestige of the Trinity, alongside intellect and will. Rather, memory is prominent in his understanding of the soul's greatness even in his earliest writings as becomes increasingly evident with Confessiones, especially Book 10.

Reflections from Epistulae 7 and 11, both written around 388, present additional distinctions regarding types of images and basic tenets of Trinitarian theology that

\footnotetext{
${ }^{20}$ See spir. et litt. 28.48-49. Gn. adv. Man. (388-390) is ambiguous as to whether, when Adam "lost that perfection which he had when made to the image of God," he lost only the perfection or the image of God itself as well (1.18.29). Subsequent writingsincluding adn. Iob 14 [exterminata] (c.399), en. Ps. 75.3 [exterminasti] (dated variously 404, 407/408, or 411/412) - make clear that Augustine understood the image of God to have been lost in Adam's original sin and that this loss persists in the sinful nature inherited by all other human beings. Lost corporately, the image of God must be remade in each person individually. See also retr. 2.24 regarding Gn. litt. 6.27.38-6.28.39.
} 
become essential to understanding human beings as created in the image of God. Epistula 7 considers three kinds of "images" that anticipate trinities of the human being discussed in De Trinitate. The first kind involves images in the mind composed as representations of things perceived through bodily senses. The second involves images in the mind imagined, either through fantasy_creative mental depictions from narratives read or told but not experienced — or false (or mistaken) speculations. The third kind involves images in the mind dealing with things we reason to, often in the realm of numbers and dimensions. The first of these Augustine will come to associate with a trinity of the outer human, which human beings have in common with animals. The latter two pertain to trinities of the inner human - the lower, active and the higher, contemplative faculties of the rational soul — that would become central to Augustine's spiritual interpretation of 1 Cor 11.7 .

Epistula 11 establishes, first, two basic elements of Trinitarian theology - the principle of inseparable operations and the doctrine of appropriations — and, second, that a trinity is evident in every nature or substance. The three persons of the Trinity-Father, Son, and Holy Spirit — are inseparably operative in God's relating to the world (omnia opera trinitatis ad extra indivisa sunt). At the same time, one may ascribe certain actions or attributes to the persons individually where scripture and the Catholic faith teach this (e.g., the creation of heaven and earth is properly ascribed to the Father and the assumption of flesh is ascribed to the Son). By way of analogy, every nature has three elements: cause, form, and permanence. Cause is the source or principle from which the thing derives. Form is the what, the this or that, of the thing and may be specified in terms of the thing's norm, rule, skill, or practice. Permanence has to do with equilibrium 
or remaining in a state, often evaluated in terms of peace, enjoyment, or pleasure. These

three elements form one inseparable unity, but have to be shown to us separately, because as bodily creatures we ourselves are a composite multiplicity.

In the eight writings from 386 to 388 discussed above, we find at least twenty-two elements that would remain important and be incorporated into Augustine's later understanding of the image of God.

1. The human being is an animal (having a quickening spirit and body). ${ }^{21}$

2. The human being is mortal (unlike God).

3. The human soul is rational (unlike brute beasts).

4. Immortal truth resides in the soul.

5. The human soul is immortal (like God).

6. The soul is incorporeal (like God).

7. The substance of the soul's nature is other than the four elements.

8. Of all things the soul is nearest to God; there is no nature but God higher than the soul.

9. The knowledge of God and of the soul are the two worthwhile inquiries of philosophy.

10. The soul was made by God and does not possess all of its Maker's powers.

11. The human that knows herself knows she was created in the image and likeness of God.

12. The human soul is in need of healing/renovation/renewal/reformation.

13. The soul must be remade in the image of God before renovation can begin.

14. The soul is healed by enacting its capacity for contemplation with God as its object.

15. Healing involves despising corporeal things, except as such things are necessary.

16. Faith and reason, scripture and Platonists, are not in opposition.

17. There are two worlds; one intelligible and one sensible.

18. Truth emanates from the intelligible world and illuminates the human soul.

19. The memory establishes an important dimension of the soul's magnitude.

20. There are three types of images in the rational soul.

21. Catholic faith affirms triune inseparable operations and the doctrine of appropriations.

22. Every existing nature expresses a trinity in its cause, form, and permanence.

It is noteworthy that all of these elements of Augustine's thought regarding God, images, human beings, and the rational soul are developed without explicitly identifying to what

${ }^{21}$ ord. 2.11.31; see also lib. arb. 6.13. 
the image of God term refers. His earliest writings tell us a great deal about human beings, including that they are created to the image and likeness of God, but precisely what the image of God names among these many attributes is not specified. 
I.2 Turning Toward the Image of God in Genesis (388-390)

In Augustine's opposition to particular Manichean teachings - the dualism of good and evil and the rejection of the Old Testament's authority for Christians - he begins to address more directly the meaning of the Gen 1.26-27 claim that human beings are created in the image and likeness of God. This polemical context gives rise to numerous works, many of which are explicitly aimed at Manichean teachings in particular-De libero arbitrio, De Genesi adversus Manicheos, De moribus ecclesiae catholicae et de moribus Manicheorum, Contra Adimantum, Contra Epistulam Manichaei quam vacant fundamenti, Contra Faustum Manicheum, and Contra Felicem Manicheum. ${ }^{22}$ Such antagonism not only proves generative for clarification, however, but also adds layers of complexity to Augustine's thinking as he seeks a coherent answer to the many interrelated questions and problems involved in understanding the image of God. These and other works from 389-395 disclose Augustine's initial inclinations regarding the meaning and practical import of Gen 1.26-27, as the image of God begins to serve as an increasingly important lens through which Augustine reads his scriptures and interprets his world.

Augustine's first of five expositions of the Genesis creation account, De Genesi adversus Manicheos (388-389), draws together elements we have already seen in Augustine's earlier writings. It presents several new insights alongside initial missteps that later expositions would seek to clarify or remedy. The Manichees alleged that any talk of human beings in terms of the image and likeness of God entails that God has a body and bodily parts, that God is corporeal and composite. Augustine responds that the

${ }^{22}$ c. Fel. is dated variously as 397/398 and 404 (See David Vincent Meconi, The One Christ: St. Augustine's Theology of Deification [Washington, D.C.: Catholic University of America Press, 2013], 86 n.20). 
Manichees are right to reject this "ridiculous" and "impious" anthropomorphic notion of God but that their prognosis fails to engender a sufficiently complex hermeneutic. ${ }^{23}$ Their solution - jettisoning the Old Testament - throws out the baby with the bath water. The appropriate spiritual or figural interpretation takes the parts of the body predicated of God to reference spiritual powers. Likewise, it is "with reference to the interior man, where reason is to be found and intelligence. ... it is above all as regards the soul [animum] that man was made to the image and likeness of God." ${ }^{24}$ This claim constitutes a watershed in Augustine's exposition of the image of God. It is here that Augustine first explicitly articulates a particular respect in which human beings are referred to as the image of God. Much greater specificity would eventually be given to the concept, but here it is the human soul [animus], with its power of reason that differentiates human beings from animals, to which the language of "the image of God" refers. A literal reading of Genesis does not say as much, Augustine reasons, but a spiritual understanding of the scriptures will not mistake the corporeal part of the human being for the image of God any more than it would mistake the body parts ascribed to God as literal in meaning.

Augustine finds suggestions of his interpretation of the image of God as a referent to "dominion" in the surrounding verses of Gen 1.26-28.

And God said: Let us make man to our image and likeness; and let him have authority over the fishes of the sea and the flying things of heaven and all cattle and wild beasts, and all the earth, and all reptiles which crawl over the earth. [And God made man to the image of God.] Male and female he made them; and God blessed them saying: Increase and multiply and reproduce, and fill the earth. Have authority over the fishes of the sea and the flying things of heaven, and of all crawling things which crawl over the earth. ${ }^{25}$

\footnotetext{
${ }^{23}$ Gn. adv. Man. 1.16.27; see also Gn. litt. inp. 7.14 and conf. 6.3.4; 6.11.18.

${ }^{24}$ Gn. adv. Man. 1.16.28; see also 2.7.9.

${ }^{25}$ I include here, in brackets, a Gen 1.27 clause not cited by Augustine until Gn. litt.
} 
When God judges it appropriate that human beings be given dominion over the brute beasts, Augustine notes that in order for this judgment to be just, there must be some inequality in their natures that warrants this differentiation. ${ }^{26}$ We saw in the earlier philosophical writings that it is rationality that distinguishes human beings from other animals, and so it must be with respect to human rationality, and not any alleged bodily superiority, that human beings rule over the brute beasts. The authority and dominion over the animals is described alongside the image of God in Gen 1.26-28 "precisely to make us understand that it was with reference, not to the body that man was made to God's image, but to the power [potestas] by which he surpasses all cattle, all animals."27 According to Augustine's philosophical anthropology, that power is reason. Although the upright posture of the human body signifies both that human nature as a whole is higher than that of the beasts "and therefore more like God" and that the human spirit ought to be turned to things above it, to eternal and spiritual realities, Augustine cautions the Manichees and his readers that the human body itself ought not be mistaken for the image of God. Likewise, however, the rational soul itself is not the image of God, but rather, it is the rational soul that is created to the image of God in its orientation or disposition.

3.19.29, several years after the expositions of Gen 1 in Gn. adv. Man., Gn. litt. inp., and conf. 13. Otherwise, this rendition of Gen 1.26-28 compiles the citations in Gn. adv. Man. 1.17.27, 1.19.30, 1.20.31. Throughout his writings, his texts lack an additional, second portion of that clause that is present in the Vulgate, ad imaginem Dei creavit illum (in the image of God he created them). Thus, whereas the Vulgate refers to the "image" three times, Augustine's texts refer to it only once (in the earlier writings) or twice (after 400).

${ }^{26}$ A similar logic operates in Augustine's early understanding of election in Expositio quarundam propositionem ex epistula apostoli ad Romanos. There must be some identifiable difference between the elect and reprobate if God is justly to judge them differently (exp. prop. Rom. 60).

${ }^{27}$ Gn. adv. Man. 1.17.28. 
Before the fall into sin, human existence was a tranquil hierarchy. ${ }^{28}$ Not only were the animals subject to rightly exercised human intelligence and reason, but those aspects of the human held in common with the animals - the non-rational part of the soul and the body — were likewise obedient to the rational soul; women were subject to men; the feelings and emotions of the soul submitted to its rational part; and the passions of the body obeyed the spirit.

Before [sin] there was a chaste coupling of male and female, accommodated to his directing and her complying; and a spiritual brood of intellectual and immortal joys filling the earth; that is to say, giving life to the body and dominating it, that is, holding it in such subjection that the spirit suffered no opposition from it, no vexation. ${ }^{29}$

In each of these pairings, the tranquility of this hierarchical ordering was not to last. After the fall into sin, the human being "was condemned to the mortality of life as we know it, and lost that perfection which he had when made to God's image. ${ }^{, 30}$ Human beings failed to keep their thoughts and desires rightly ordered and lost the original tranquility in which they and the creation existed when first made to God's image. Animals, women, children, slaves, emotions of the spirit, and passions of the body, were no longer submissive, respectively, to human beings, to men, to parents, to masters, to the rational soul, and to the soul as a whole. ${ }^{31}$

In Augustine's spiritual reading, the six day creation account-seven, including the Sabbath - allegorizes a history of God's dealings with human beings that ends with

${ }^{28}$ See the discussion of "permanence" in ep. 11.

${ }^{29}$ Gn. adv. Man. 1.19.30.

${ }^{30}$ Gn. adv. Man. 1.18.29.

${ }^{31}$ See also mor. 1.30.63 for Augustine's consideration of the "household codes" of Col 3 and Eph 5. 
perfectly renewed freedom and eternal bliss. ${ }^{32}$ Just as on the sixth day God creates human beings in the image of God, so also in the sixth age of the world, the age of the Church, "our Lord is born in flesh." ${ }^{33}$ At this point, another hierarchical pairing appears. "Just as on that day male and female (Gen 1.27), so also in this age Christ and Church ... Christ rules the souls that defer to him." ${ }^{34}$ Those who belong to the body of Christ, the Church, "may be tamed and domesticated by him, whether they had been given over to fleshly concupiscence, ... curiosity, ... [or] pride." And, as the vices of the corporate Church are brought under the dominion of Christ, the Church is fed by those who imitate Christ together, feeding on "the holy scriptures and divine law ... partly to provide moral guidance for human life together ... partly to lend vigor to faith, hope, and charity right up to eternal life." 35 The mortification of the Church's corporate vices prepares the way for the cultivation of virtues in the Church's common life that leads to eternal life. At that point, the seventh age will commence with Christ's return and a new day of perfect tranquility will dawn that will know no evening.

${ }^{32}$ See Gn. $a d v$. Man. 1.23.35-41. The seven ages begin, respectively, with Adam and creation, Noah, Abraham, David, Babylonian captivity, the incarnation, and the second coming.

${ }^{33}$ Gn. $a d v$. Man. 1.23.40. It is interesting to note that Augustine does not quote Col 1.15, here: "He is the image of the invisible God, the firstborn of all creation." This text would fit perfectly with this analogy of the sixth day to the sixth age that Augustine often repeats, as well as the appropriation of the image of God pairings to Christ and the Church. Col 1.15 is one of two passages that identify the Son as the image of God, the other being 2 Cor 4.4. That the Son is "the image of the invisible God, firstborn over all creation" fits his argument here so perfectly but is not mentioned might be taken as an indication that the verse was simply assumed by Augustine and his audience. A search of his writings, however, shows that Augustine never quotes the first clause of Col 1.15, even though he does refer to the subsequent phrase, "firstborn over all creation" (See Trin. 1.12.24). That Augustine deals so extensively with the image of God without referring to the clause "He is the image of the invisible God" [imago dei invisibilis] would seem to indicate that his text read differently at this point.

${ }^{34}$ Gn. adv. Man. 1.23.40.

${ }^{35}$ Gn. adv. Man. 1.23.40. 
In addition to this world-historical allegory that reads the image of God in the terms of Christ and the Church, Augustine employs another historical allegory for the six days of creation that operates at the level of the human individual. ${ }^{36}$ A series of quotes suggests how he understands the life of the individual believer to progress, including the human being made in the image of God on the sixth day:

We also, one and all, have those six days in our personal lives, distinguished from each other in good works and an upright way of life, after which we should be hoping to rest. On the first day ... we begin by believing visible things and it is on account of this faith that the Lord was prepared to appear in visible form. On the second day ... we distinguish between things of the flesh and things of the spirit, ... The third day is the one on which we separate our minds from ... fleshly temptations ... to bear the fruit of good works ... On the fourth day, ... we see what unchangeable truth is, which shines in the soul like the sun; and we have the soul made a participant in this truth itself; and bestowing order and beauty upon the body, ... Made stronger and braver by awareness of these things, we begin to produce results on the fifth day, ... in the interests of brotherhood and good fellowship; we produce from bodily activities, ... On the sixth day, ... we produce from the stronghold of our minds, ... we direct all the movements of our spirit ... at the service, that is, of reason and justice, not of foolhardiness and sin. In this way too may the man be made to the image and likeness of God, male and female, which here means understanding and activity. ... After the works of this sort of six days ... we should be hoping for everlasting rest ... to enjoy [our] selves in merrymaking. ${ }^{37}$

Operative in this account of human development are the distinctions of visible, changeable, bodily activity on the one hand and invisible, unchangeable, spiritual understanding of truth on the other. Although later writings more often depict human development in four stages rather than seven (six plus one day of rest), the basic

\footnotetext{
${ }^{36}$ Likewise, $s .259$ (c.394/400 CE) locates the image of God in the sixth moment of all three registers - the days of creation, of world history, and in the history of an individual: "Just as man was formed in Genesis on the sixth day in the image of God, so too in this age, as in the sixth day of the whole course of time, we are made new in baptism in order to receive the image of our maker" [ut recipiamus imaginem conditoris nostri) (s. 259.2). See also c. Faust. 13.8.

${ }^{37}$ Gn. adv. Man. 1.25.43.
} 
distinctions and gradual progression from the former aspects to the latter remain, as does the telos of eternal rest in and enjoyment of God. ${ }^{38}$ This characterization of the moral life is evident in De moribus ecclesiae catholicae, a work contemporary to Augustine's first exposition of Gen 1.

Augustine composes De moribus ecclesiae catholicae as one of two parts of a work that sets Catholic teaching and practice alongside the life and teachings he knew firsthand as a Manichean "hearer." This treatise attends less to the propositional content of faith than it does to the way of life by which Catholic believers might merit to know this faith. For, it is by actually living this moral life that one comes to believe. ${ }^{39}$ The operative assumption here is that "One becomes conformed to that which one loves." prioritizing the love of God above all other things, so Augustine argues, the Catholic moral life gradually shapes human beings more perfectly into the image of God. Because love, for Augustine, is a virtue, and all virtue talk is talk about perfection, it comes as little surprise that Augustine frames his discussion of the image of God in terms of virtue. This framing would prove an enduring feature of his expositions of the image of God. Importantly, however, the ways in which scriptural references to the image of God are fitted to this framework will unfold differently as his own theology develops over time.

Augustine understands virtue as "a perfectly correct disposition of our mind [that] unites us with God." ${ }^{, 41}$ As a mental disposition, virtue pertains essentially to the human soul and only derivatively to the body - the soul being an intelligible reality whereas the body is a sensible one. Furthermore, because God is non-corporeal, God can be known by

${ }^{38}$ See exp. prop. Rom. 13-18.2, div. qu. 66, ench. 31.118, and qu. ev. 1.41.

${ }^{39}$ mor. 1.20 .37 .

${ }^{40}$ mor. 1.21.39.

${ }^{41}$ mor. 1.11.19. 
worthy souls only through the intelligence. The mind is like God in being invisible as well as intelligible. When the mind is granted to become like God, it does so by subjection to God in order to be enlightened and illumined. Here again, we perceive some general contours of Augustine's anthropology: human beings are made up of body and soul, and the human soul includes, in addition to its capacities for passion or emotion that it has in common with the souls of non-human animals, a rational or intellectual element (associated with the mind) which possesses the capacity to direct the lower (non-rational) elements of the soul as well as the appetites of the body.

Loving God in the form of the Son renews and heals human nature of the effects of $\sin .{ }^{42}$ By loving God, "We are becoming conformed to the image of the Son of God."43 Loving God with one's mind restores human nature - one's being or substance — to its original fullness. In the great chain of being God is the highest being from which all other natures derive their existence, all the way down to nothingness at the bottom. Whereas evil is a deficiency in one's nature or substance, "God is nothing other than being itself." ${ }^{44}$ The further the mind's loves and desires foolishly wander to increasingly lower things than God, the more it suffers unhappiness. The more the mind desires and loves God in subjection to God, the greater the soul's experience of joy and freedom. The rational soul sees and loves the Father through the Son, and the soul's love (which comes from the Holy Spirit) for the Son conforms the human soul to the Son rather than to the

\footnotetext{
${ }^{42}$ For a classic study of Augustine's thought on the dynamics of divine and human love, and particularly how love heals human nature, see John Burnaby, Amor Dei: The Study of the Religion of St. Augustine (London: Hodder and Stoughton, 1947), 104-110.

${ }^{43}$ mor. 1.14.24. See also 1.16.29, and Rom 8.29.

${ }^{44}$ mor. 1.14.24.
} 
world and its lesser, temporal goods. ${ }^{45}$

The references to Rom 8.29 in this context_For those he foreknew he also predestined to be conformed to the image of his Son in order that he might be the firstborn among many brothers ${ }^{46}$ — are a first for Augustine and occur in proximity to several other scriptural citations that would become equally important to his mature understanding of the image of God. Augustine again refers to the old man and new man of Col 3 and Eph 4 alongside two other citations that first appear in this context: Just as we have borne the image of the earthly man, let us also bear the image of the heavenly man (1 Cor 15.49); ${ }^{47}$ and Even if our outer self is being corrupted, our inner self is being renewed from day to day (2 Cor 4.16). ${ }^{48}$

At least three observations about Augustine's uses of these scriptural texts are worth recounting at this point. First, looking back from the vantage of his mature writings, what is most interesting about Augustine's initial use of these three texts-Rom 8.29, 1 Cor 15.49 , and 2 Cor 4.16 - is that he treats them as if they are talking about the same thing — namely, the progressive renewal of the image of God in the human being. Here, Augustine's attention is drawn to the fact that they all mention the divine image, since his concern is to encourage its renewal by means of virtuous living, not only growth toward but also the attainment of perfection in this life. ${ }^{49}$ Augustine would come to differentiate the three pairings of outer human and inner human (2 Cor 4), the earthly

\footnotetext{
${ }^{45}$ mor. 1.13.22; See Rom 8.29.

${ }^{46}$ praedestinauit enim conformes nos fieri imaginis filii eius (mor. 1.13.22).

${ }^{47}$ sicut portauimus imaginem terreni, portemus et imaginem coelestis: hoc est, exuite ueterem, et induite nouum (mor. 1.19.36).

${ }^{48}$ si et exterior homo noster corrumpitur, sed interior renouatur de die in diem (mor. 1.19.36).

${ }^{49}$ In De sermone Domini in monte (394) Augustine will state more explicitly that some human beings have achieved this perfection.
} 
human and heavenly human (1 Cor 15), old human and new human (Col 3 and Eph 4), but here all three pairings are harmonized as though referring to the same two-fold reality—namely, the disordered love of lower goods (i.e., visible, sensible, temporal, mutable, corporeal), on the one hand, and the righty ordered love of God and all things in God, on the other, including both higher goods (i.e., invisible, intelligible, eternal, immutable, incorporeal) as well as those lower. Second, in Augustine's mature writings, in which conformation to the image of God is construed in terms of the image of the Trinity, those scriptural passages that might seem to associate the image of God with the second person of the Trinity—such as Rom 8.29, 1 Cor 15.49, 2 Cor 4.4, Col 1.15, and 1 Jn 3.2-will no longer be interpreted as pertaining to progressive renewal in this life but instead to the resurrected spiritual body in the next. Third, Augustine introduces Rom 8.29, 1 Cor 15.49, and 2 Cor 4.16 - and here incorporates Col 3.9-10 and Eph 4.23-24all in a discourse on virtue within the morality of the Catholic Church. Although Augustine addresses fortitude, justice, and prudence, it is primarily temperance, a virtue directly opposed to concupiscence, that bears upon the image of God within the twofold scheme of reordering disordered loves. The purpose of temperance - as the virtue opposing the vice of covetousness that, in this period of Augustine's writings, is the root of all evils - "is to strip off the old man and put on the new man and be made new in God. That is, to hold in contempt all the allurements of the body and popular acclaim and to bestow one's whole love on things invisible and divine." ${ }^{50}$ Because the image of God is interpreted in terms of a gradual progression within the context of the Catholic moral life and the specific framework of virtue, questions inevitably arise about the image of

${ }^{50}$ mor. 1.20 .36 . 
God as it pertains to those outside of or not yet participant in the Catholic community, tradition, and practices. Written in and for the sixth age of world history, the age of the Church, the addressees are also primarily those in the sixth age of their personal history - those who have already been remade in the image and likeness of God - those whose outer person is decaying and whose inner person is being renewed day by day. ${ }^{51}$ It is not clear from this text what, if anything, we can say about the image of God with respect to the non-baptized or with respect to pagan virtue.

Augustine does provide occasional glimpses of his thinking on such matters during this period in Rome and Thagaste. For example, his assertion that perfection follows from virtuous living after baptism opposes the Manichean demand for perfection as a pre-condition of baptism. "From that sacred bath the renewal of the new man is begun in order that by making progress some may attain perfection more quickly, others more slowly." 52 Citing 2 Cor 4.16 Augustine identifies baptism with the beginning of a daily renewal "in order that [the new man] may attain perfection, [but] you [Manichees] want to begin with perfection." ${ }^{, 53}$ If renewal begins with the image of God being remade in baptism and one becomes more "like" God progressively — as the Holy Spirit graces the individual with love for God and as the rational soul willingly subjects its lower desires to its love for God-then it seems that other-than-baptized-believers are neither progressively renewed nor yet re-made in God's image and likeness. At this early stage in his development, within a few years of his own baptism, Augustine still believes that subsequent to the Fall all human beings are born lacking the image of God. God remakes

\footnotetext{
${ }^{51}$ See div. qu. 58.2.

52 mor. 1.34.80.

${ }^{53}$ mor. 1.34.80.
} 
human beings in the image of God in response to the right use of their free will, choosing to believe and willing to obey God's law rather than giving in to the passions and appetites of the lesser elements of human nature held in common with the beasts. 
I.3 Augustine's Priesthood: On Genesis, the beatitudes, and Romans (391-395)

Augustine's understanding of the image of God develops considerably during his years as a priest prior to becoming a bishop (391-395). His reflections are given distinctive shape in this period, at least in part, due to intensive periods of retreat that Augustine secures with the expressed intent of studying scripture. ${ }^{54}$ One result of this intentional focus upon scripture is the specification and shape given to his understanding of the image of God. This can be seen, first, by the much more accented conviction that the Son is the image and likeness of God, whereas human beings are created to the image and likeness of God and, second, by his discovery of "four stages of man" in his exposition of Paul's Epistle to the Romans. One consequence of the former distinction between the Son qua image on the one hand and a human participation in attributes on the other is that the pairing of the Son as Wisdom itself with the mind's contemplation of wisdom also comes into prominence. Here, Augustine's primary contention is that the human being is like God insofar as it is turned toward God's image, toward the Son, but only the Son of God is the image and likeness of God itself.

In his second exposition of Gen 1, De Genesi ad litteram inperfectus, Augustine affirms that the Father and Son are invisible, immutable, consubstantial—being numerically one in substance as opposed to being of the same kind of substance - and coeternal—neither pre-existing the other. In short, they are completely equal. ${ }^{55}$ The Creator's divine nature, however, is clearly distinct from the creaturely nature of the human being that displays none of these attributes. The human being is like non-human

\footnotetext{
${ }^{54}$ See ep. 21.3 .

${ }^{55}$ On co-equality, see De fide et symbolo, where in addition to the Father's and Son's equality Augustine affirms divine ineffability (9.17-18). On con-substantiality, see also div. qu. 23.
} 
animal creatures in that it does not possess these divine attributes. The human being's connection with and distinction from animals is signified in Genesis by their creation on the same day as land animals on the one hand and by the dominion over other animals proper to them by virtue of the rational soul. ${ }^{56}$

This superiority of human beings over all other creatures is indicated by the scriptural "Let us make" rather than "Let there be" as is used in the creation of all other things. In each case making and saying are simultaneous, however, in all of the previous "Let there be ... and there was ..." statements, the Son made at the Father's bidding. In this final "Let us make man to our image and likeness," the human being is uniquely made by the Father and the Son together. ${ }^{57}$ Augustine overlooks for the time being the potential Trinitarian implications of the subsequent first person plural "to our image" and “in our likeness" to which he gives considerable attention in later writings.

Image and likeness reference distinct claims regarding how one thing is related to another. The term "image" indicates that one thing is "derived from the other ... as it were, printed off from it." ${ }^{, 58}$ According to Augustine's usage, this meaning of image entails that all things are "like" [simile] God in some respect, and yet it does not follow that all images necessarily include "likeness" [similitudo]. Image entails "like" but not "likeness." Augustine draws upon the Platonic theory of Forms or Ideas in making this distinction. Whereas Wisdom itself (the Form or Idea) is what it is without participating in anything higher, a thing that is wise is not Wisdom itself but participates in Wisdom. Similarly, a thing that is chaste, red, or beautiful is not the same thing as chastity itself,

${ }^{56}$ Gn. litt. inp. 16.55.

${ }^{57}$ Gn. litt. inp. 16.56. See also Travis Ables, Incarnational Realism: Trinity and the Spirit in Augustine and Barth (London and New York: Bloomsbury T\&T Clark, 2013).

${ }^{58}$ Gn. litt. inp. 16.57. 
redness itself, or beauty itself. In each case the thing which manifests the relevant attribute participates in the Form or Idea from which the particular attribute emanates or derives. So also in the case of the likeness of God: most things that are like God (e.g., an image) are not God's likeness. Thus, with respect to God's creation of the human being, the addition of "and likeness" subsequent to "image" indicates an importantly distinct, additional claim. Whereas a human creature might be like God in a particular or various respects, the likeness of God could only refer to the Son of God. ${ }^{59}$

That human beings are created "to our image and likeness" means that the "image" through which they were made (John 1.3) is not like God such that it needs to participate in "likeness itself." Instead, this image $i$ s the very likeness in which all other things that are like God participate. The addition of "likeness" [similitudo] to "image" [imago] in Gn 1.26-27—ad imaginem et similitudinem - indicates that human beings are created to $[a d]$ the image of God that is God's likeness itself - that is, the Son. In stating that the human being is created to $[a d]$ the image and likeness of God, according to this early exposition by Augustine, Genesis teaches that the particular object toward which the human being is properly oriented in its creation is not just any image of God, of which there are many, but that nature that exhibits God's likeness itself - the attributes of which are shared by Father and Son in their equality and unity of substance.

Because all things created by God are created through the Son of God, the Father's likeness, each creature will display in its distinct nature the particular attributes of God by which they are formed. ${ }^{60}$ Only rational souls share in the Wisdom of God, the Logos, and in this respect they alone are shaped not only through but also to the Son, to

\footnotetext{
${ }^{59}$ See also div. qu. 23.

${ }^{60}$ See Jn 1.3, Col 1.16.
} 
God's likeness itself. Of all creatures, “only rational souls can be called wise."61 By nature, the human rational soul is ordered toward wisdom.

No nature is nearer to God than the human mind. ${ }^{62}$ The mind or rational soul communes with and contemplates Truth itself immediately, not needing any nature to mediate between the rational soul and God. ${ }^{63}$ Truth itself "is also called the likeness and image of the Father and his Wisdom." ${ }^{, 64}$ And, for this reason, "We are quite right, therefore, to take the words, Let us make man to our image and likeness as referring to this, the innermost and principal element in humanity, that is, as referring to the mind.",65 This claim, that the image of God refers to the mind [mens] is no more a refutation of the earlier association of the image of God with the soul [animus] than either of these are a refutation that the human creature is created to the image of God. Each is, rather, a specification. The human soul [animus], as distinct from the body, differentiates the human rational animal from the non-rational animals. The mind is the particular part of the human soul that differentiates it from the non-rational soul. Therefore Augustine can make claims about the human mind parallel to and overlapping with those made about the human soul when the point of comparison is differentiation from the non-rational animal. The "human mind [mens humana] ... holds the leading place in human nature ... [that] separates it from that of the brute beasts" and it is with respect to the mind "that the worth of the whole human being is to be reckoned." ${ }^{66}$ All else in the human being is held in

\footnotetext{
${ }^{61}$ Gn. litt. inp. 59.

${ }^{6}$ exp. prop. Rom. 58.8.

${ }^{63}$ See also s. 214, and div. qu. 51.2, 4, where Augustine argues that creatures with a rational mind participate in unchangeable truth.

${ }^{64}$ Gn. litt. inp. 60.

${ }^{65}$ Gn. litt. inp. 60.

${ }^{66}$ Gn. litt. inp. 60.
} 
common with non-human animals and, thus, is to be subordinated to the mind, the rational part of the human soul.

Augustine again considers whether the erect stature of the human body constitutes a possible exception by which human beings might be valued more highly than the brute beasts. Here, the erect posture of the human being is compared to the second person of the Trinity vis-à-vis the Father. The human propensity to look to the sky rather than turn away from it, as do animals that look downward, signifies that the Son does not turn away from the Father. This corporeal similarity is quite minimal, however. Whereas the Son is like the Father in every respect, being consubstantial and the Father's likeness itself, the human body is not like the sky in its nature and merely looks toward it. The erect stature of the human body signifies the rational soul that differentiates the human from brute beasts but does not itself constitute the image of God or contribute to the elevated value of the human nature above that of the beasts. ${ }^{67}$

We have already observed that human beings are like [simile] God and created to the likeness [ad similitudinem dei] of God whereas only the Son of God is [est] the likeness of God. We have not addressed whether the human being that is like God is the image of God. Although in this text human beings are never said to be the image of God, neither is it said that they are not. Rather, Augustine's point is that the addition of "likeness" in Gen 1.26 specifies that the image to which human beings are created is that of the Son of God. Or, negatively, the human being was not created to an image of God that is merely like God in some respect without being God's likeness itself. Only the Son through whom all things are created is both the image and likeness of God. What is

${ }^{67}$ See also div. qu. 51.3. 
unique about human beings is that they are created not only through but also to the image and likeness of God. We have seen that everything created by God is like God, even those creatures without a rational soul or a living body. It is with respect to the rational soul that human beings are like God in a manner that exceeds the ways that all other creatures are like the Creator. In all of this talk of the human being-whether mind or soul—being like and being to the likeness, Augustine never says that the human being or the rational soul is the image of God. And, the one biblical text that states that a human being other than Jesus Christ is the image of God, 1 Cor 11.7, is a text that has not yet, but soon will, become important to Augustine's understanding of the image of God. It might seem obvious or sufficiently established elsewhere that the rational soul is the image of God, even if not the likeness of God, and that Augustine need not restate the point or that he likely would have made this implicit claim explicit had he finished the manuscript. As was the case among Augustine's early writings, however, other works from this period and later suggest a more complicated picture.

Consider, for example, Augustine's response to Adimantus, Contra Adimantum Manichei discipulum (394). The Manichean opposition to the Old Testament included the charge that human beings could not have been created to the image and likeness of God, because Jesus's statement to the Pharisees, "You are from your father, the devil," excludes some people from having been made to God's likeness. ${ }^{68}$ Augustine counters that the Gen 1 reference to human beings having been made to God's likeness pertains to those human beings existing before human sin, whereas Jesus was speaking to sinners and unbelievers. Those who lived before the Fall were to the image and likeness of God

\footnotetext{
${ }^{68}$ Jn 8.44. See c. Adim. 5.1.
} 
and were not from the devil in the respect that Jesus uses the phrase whereas those who lack faith and who live after the Fall are no longer to the image and likeness of God and thus are "from the devil." Similarly, Augustine interprets the old/new distinction in Col 3.9-10 as indicating that the human being was made to the image of God according to the spiritual formation or renewal of the Christian believer. The recreated human lives a new life in imitation of Christ.

And to teach that at one point we lost this, he calls it a renewal. For he speaks as follows: Stripping off your old self with its actions, put on your new self that is being renewed in the knowledge of God in accord with the image of him who created it (Col 3.9-10). People who have been renewed to his image are therefore sons, and they have been made like him even to the point of loving their enemy. As the Lord says, we ought to love our enemies in order that we may be like our Father in Heaven. ${ }^{69}$

According to Augustine, it is only Christian believers who have been remade in the image of God and love their enemies in this way. In Augustine's writings from this period human likeness to God consists most prominently in the moral uprightness of the Catholic Christian's life and, in particular, the ways in which this morality departs from other moralities since others lack the benefits of the remade image of God. ${ }^{70}$

Excursus: A late addendum to De Genesi ad litteram liber inperfectus

Augustine offers a revised, alternative account of image and likeness more than thirty years later in a section of De Genesi ad litteram liber inperfectus that was added as Augustine worked through his Retractiones. ${ }^{71}$ There, Augustine maintains that "to our image and likeness" is understood sufficiently where the likeness of God to which human

${ }^{69}$ c. Adim. 5.2. See also, Mt 5.44-45

${ }^{70}$ Other texts from this period in which moral uprightness is a primary referent of the image of God include en. Ps. 94, s. 260A, and c. fort.

${ }^{71}$ See Gn. litt. inp. 16.61-62; retr. 1.18; John Burnaby, Amor Dei, 144. 
beings are created is the Son. But, he also specifies several aspects, the importance of which will be impressed upon him in the intervening years: The Son is the "Word of God," the "only-begotten" of the Father, whereas "man himself is not that same image and likeness, equal to the Father."72 Looking back from the vantage of the late 420's Augustine can now affirm that the human is the image of God (even if it cannot be said to be God's likeness itself).

Unlike the Son, who is God's likeness itself, the human is the image and likeness of God without being equal and co-eternal with the Father-it is a likeness of similarity without being "likeness itself." 73 Augustine notes that even Adam before the Fall was not equal to Christ in these respects. Augustine's stated scriptural warrant for this revision is 1 Cor 11.7-man is the image and glory of God, but woman is the glory of man. His purpose is to show that human beings are not created merely to the image of God, but that it is proper to say of a human being that it is the image of God. This is not the only change, however.

The Form in the likeness of which human beings have been created has shifted from the Son to the Trinity. The revision amounts to this - in De Genesi ad litteram liber inperfectus Augustine argued that the Son alone is the image and likeness of God. Whereas all of creation as a whole and every creature individually is created through the Son — and therefore shows signs of this in each thing's cause, form, and persistence — it can only be said of human beings that they are created to the image and likeness of the

\footnotetext{
${ }^{72}$ Gn. litt. inp. 16,60.

${ }^{73}$ Augustine maintains a formal distinction along the lines of that which he had advocated between "like" and "likeness" (qua Form), but now alters the labels such that "likeness" can refer either to that which participates in the Form or the Form itself. As a warrant for this reconsideration, Augustine cites Jas 3.9-men [homines] have been made to the likeness of God.
} 
Son, that is, Wisdom itself. The Son is the image and likeness of God whereas human beings are created to the image and likeness without themselves being the image and likeness of God. Citing 1 Cor 11.7, Augustine now argues that the human being is the image and likeness of God, though not God's likeness in substance or in eternal existence. We will consider the manifold reasons and scriptural warrants for this revision in sections I.5 and I.6. The later reading turns, in part, on the plural indirect object (or dative) of Gen 1.26-27 in or to whom the human being has been created. Initially Augustine held that the Father and Son created human beings together_- "Let us make man ..."- and that the Son is the image of the Father to which human beings had been created. In his revision Augustine notes that human beings are not created "to my image" (as if the Father were speaking to the Son of the Father as the image) nor "to your image" (as if the Father were speaking to the Son of the Son as the image), but "to our image." Although he would make an observation that anticipates this revision just a few years later in Confessiones, it would take Augustine more than twenty years from his second exposition of Genesis to work out the many implications of this significant modification of his early understanding of the image of God.

Beatitudes as eights steps in moral progress

Much as a work on virtues and the morality of the Catholic Church followed Augustine's first exposition of Genesis, his second is followed by an exposition of the beatitudes in De sermone Domini in monte. This work finds Augustine drawing an analogy between the well-regulated human being and a well-ordered kingdom somewhat 
reminiscent of Plato's Republic. ${ }^{74}$ The eight beatitudes offer maxims describing the blessed human being, a person for whom all those parts that are held in common with the beasts are ruled by the mind and whose mind, in turn, is subject to the higher power of Truth Itself, the only begotten Son of God. Similar to the allegory of the six ages of creation, the beatitudes are applied to the individual as a series of stages, an eight-step order through which an individual gradually progresses towards the perfect peace of the children of God who inherit God's kingdom. ${ }^{75}$

The sixth maxim describes those who, having escaped from the entanglements of worldly desire, are having their hearts progressively purified. These persons are pursuing the renewal of their inner life. The motifs of the allegorical six ages related to the image of God are repeated here, though, curiously, no explicit mention of the image of God is made. The seventh maxim, however, suggests how Augustine might be conceiving of the image where he discusses the rational soul in relation to the "likeness of God."

The seventh maxim of the beatitudes also evidences similar parallels to those we have already observed, including the attainment of the goal to which human natures are ordered in creation - namely, the likeness of God in an enduring submission of the lower faculties to the rational soul. "[Wisdom itself] is the contemplation of truth, making the whole man peaceful, and taking on the likeness of God."76 The pursuit of wisdom through the contemplation of truth brings the tranquility of order to every aspect of human existence — both at the individual and the corporate level. "Wisdom coincides with peacemakers for with peacemakers all things are in proper order, and no passion is in

\footnotetext{
${ }^{74}$ s. Dom. m. 2.9.

${ }^{75}$ See div. qu. 58.2.

${ }^{76}$ s. Dom. m. 3.10.
} 
rebellion against reason, but everything is in submission to man's spirit because that spirit is obedient to God." "77 The kingdom of heaven is the "perfect and supreme wisdom of the rational soul." ${ }^{, 78}$ Those who by loving God and others aid in bringing about this kingdom of peace, are conformed to the object of their love. "To the peacemakers - as those who are perfected in wisdom, and conformed to the image of God through regeneration unto the new man-likeness of God is imparted."79

It would seem that this likeness of God that is imparted to human beings who are made regenerate (i.e., remade in God's image) might be achieved either in this life or the next, depending on one's criteria and definition of perfect wisdom. At this point, in contrast to his mature writings, Augustine holds that each of these steps toward perfection can be attained in this present life, "as we believe them to have been fully attained in the case of the Apostles." ${ }^{\prime 80}$ The apostles and martyrs are evidence that there is great reward for enduring bodily suffering "with equanimity and cheerfulness" when it is undergone for the sake of justice, which requires love. ${ }^{81}$ Importantly, endurance of suffering itself is not automatically beneficial and schismatics cannot hope to share in its rewards.

The occasion for suffering with tranquility and its rewards need not come about only as a result of persecution or from others - they can just as easily be self-initiated. Fasting, for example, is a means of cleansing the heart, directing its attention singly to God rather than dividing its intention between the inner and outer world:

our whole intention is to be directed toward the joys that are within, lest we be conformed to this world by seeking a reward that is without, and

\footnotetext{
${ }^{77}$ s. Dom. m. 3.11.

${ }^{78}$ s. Dom. m. 3.12.

${ }^{79}$ s. Dom. m. 3.12.

${ }^{80}$ s. Dom. m. 3.12. See retr. 1.19.2, exp. prop. Rom. 55.1.

${ }^{81}$ s. Dom. m. 3.13.
} 
lest we thus lose the promised blessedness, which is all the more sound and firm according as it is in the inner man - the blessedness by which God has chosen us to be conformed to the image of his Son. ${ }^{82}$

The mind or rational soul that is preeminent within the human controls and purifies the other members (the soul's lesser parts and the body). Such asceticism finds joy not externally but within. Purity results from the mind cleansing and restraining the willful passions and bodily appetites. Fasting, then, is a means of withdrawing from worldly pleasures, bringing inner joy by subjecting one's soul and body to Christ, and purifying one's rational soul so as to be an unblemished mirror in which God can view His reflection. When this purification takes place and God looks upon us, "we shall reflect the glory of God as in a mirror and we shall be transformed into His very image." ${ }^{, 83}$ Like the role played by temperance in De moribus ecclesiae catholicae, fasting is a practice of restraining bodily passions that, by loving God, transforms the practitioner into the likeness of God as a reward. ${ }^{84}$

Of course, suffering and its rewards are also at times brought about by others. Augustine often has in mind suffering caused by persons hostile to the Christian faithboth those who assail God's truth and those who merely resist it. ${ }^{85}$ In both cases the uncleanness of their hearts derives from a love for temporal things of this world in

${ }_{83}^{82}$ s. Dom. m. 12.40 .

${ }^{83}$ s. Dom. m. 12.42.

${ }^{84}$ Regula: ordo monasterii (unknown date) likewise begins with "Love God above all else" (1) and Regula: Praeceptum (unknown date) includes the exhortation, "To the extent that your health allows, subdue your flesh by fasting and abstinence from food and drink" (3.1) (See George Lawless, Augustine of Hippo and his Monastic Rule, [Oxford: Clarendon Press, 1987]).

${ }^{85}$ Augustine works with the scriptural figures of dogs and pigs for these two groups, respectively (Matt 7.6). See s. Dom. m. 20.68. 
disobedience of God's instruction to renounce the world in order to be clean. ${ }^{86}$ How are believers to interact with those who are impure and who, because they improperly love the things of this world, bring suffering upon themselves and others? Should Christians speak the truth openly, lie, or perhaps conceal the truth when speaking to those whose lives are in opposition to Catholic faith and love? Augustine holds that concealing the truth from those who would be unable to receive it due to their uncleanness is not lying. However, only when that which hinders non-believers from receiving the Catholic faith has first been removed through the cleansing of catechesis and baptism will they be capable of receiving the truth disclosed.

Here, in the same year that he composes De mendacio, Augustine cautions: "But we must not therefore believe that it is lawful to tell a lie, for it does not follow that falsehood is spoken when the truth is not revealed." ${ }^{\prime 87}$ Concealing the truth is permitted. Lying is not. In some cases, the truth should be disclosed even when confronted by those who are unclean and thus cannot receive it due to the hindrance of their own uncleanness. ${ }^{88}$ For, although those who are unclean might not be capable of receiving the truth, there may be others present who are capable of hearing and will benefit if the question under consideration provides useful guidance for salvation. ${ }^{89}$ Augustine's concern, or at least his attention, is somewhat broader at this point than in De moribus ecclesiae catholicae. Here, he imagines that those present might include both those who have been remade in the image of God and those who have not been so remade. One's

\footnotetext{
${ }^{86}$ s. Dom. m. 20.69.

${ }^{87}$ s. Dom. m. 20.69.

${ }^{88}$ s. Dom. m. 20.70.

${ }^{89}$ Augustine gives the example of Jesus' teaching to render to Caesar those coins bearing Caesar's image, "and to God that which belongs to God" (s. Dom. m. 20.70).
} 
word of truth might not benefit the explicit addressee but others who witness one's

confession.

Four stages of humanity in Romans

Toward the end of this period Augustine outlines for the first time "four stages of man" as a way of framing and summarizing Paul's theology in Romans. ${ }^{90}$ As with his allegorical readings of the six days of creation, of human history, and the life of the individual, the image of God initially appears as a primary concern in the penultimate stage ${ }^{91} \mathrm{He}$ unfolds this new framework in Expositio quarundam propositionem ex

${ }^{90}$ These four stages are not those that pertain to the progression of faith and which Eugene TeSelle describes as "a basic continuity in Augustine's way of analyzing the issues. From first to last he is thinking in terms of four stages" (Eugene TeSelle, "Response I - Augustine and Theology," Augustinian Studies 36:1 (2005): 71-83, 76). TeSelle's progression outlines 1) divine calling, 2) response of faith, 3) infusion of grace, and 4) works of obedience. Augustine's exposition owes much to his better-known treatise of this period, De libero arbitrio. The will's prerogative to believe or not to believe is foundational to the interpretation Augustine gives to Romans as a whole (and to chapter seven in particular) and gives a distinctive shape to the four stages in the early writings that would have to be modified with Augustine's revision of the relation of grace and free will with respect to predestination in Ad Simplicium. TeSelle's observation is more accurate of Augustine's mature writings than those between his propositions on Romans and De spiritu et littera. For discussions of comparing Augustine's exposition of Romans to earlier and later works, see TeSelle, "Response I-Augustine and Theology;" and Paula Fredricksen, "Augustine and Israel: Interpretatio ad Litteram, Jews and Judaism in Augustine's Theology of History" in Engaging Augustine on Romans: Self, Context, and Theology in Interpretation, eds. Daniel Patter and Eugene TeSelle (Harrisburg, PA: Trinity Press International, 2002), 91-110.

${ }^{91}$ The seven days of creation allegory maps out the following periods: 1) Adam to Noah, 2) Noah to Abraham, 3) Abraham to David, 4) David to Babylonian exile, 5) Babylonian exile to Jesus Christ, 6) Jesus Christ to his second coming, 7) Jesus Christ's second coming into eternal rest or perdition. The four stages of human history: 1) Adam to Moses, 2) Moses to Jesus Christ, 3) Jesus Christ to his second coming, 4) Jesus Christ's second coming into eternal rest or perdition. See Gn. adv. Man. 23.35-41, exp. prop. Rom. 29.1-10, ench. 31.118. 
epistula apostoli ad Romanos (394). ${ }^{92}$ This four-stage framework becomes a mainstay of Augustine's soteriology that he would affirm even twenty-seven years later in the closing of “a work of Augustine's high maturity," Enchiridion sive de fide, spe, et caritate. ${ }^{93}$

Unlike the earlier writings that present seven or eight steps as a gradual progression of growth in virtue, the transitions in the four-stage procession mark both progress and regress.

Augustine's collection of propositions on Romans introduces this framework by relating all four stages to the concupiscence of the flesh:

Let us distinguish these four stages of man: prior to the Law [ante legem], under the law [sub lege], under grace [sub gratia], and in peace [in pace]. Prior to the Law, we pursue fleshly concupiscence; under the Law, we are pulled by it; under grace, we neither pursue nor are pulled by it; in peace, there is no concupiscence of the flesh. ${ }^{94}$

The exposition that follows this prefatorial statement seeks to identify to which of these four stages Paul is referring in various passages in Romans in order to untangle the complex of theological propositions that comprise Paul's argument. Augustine's identification of concupiscence as the red thread running throughout and bringing into relief the implications of law and grace in the four stages finds warrant in Paul's repeated

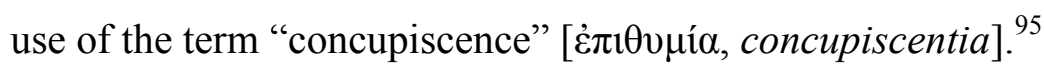

Before the law, ante legem, human beings do not struggle against the inordinate desires for temporal worldly things that are lesser goods than God, the highest good. The

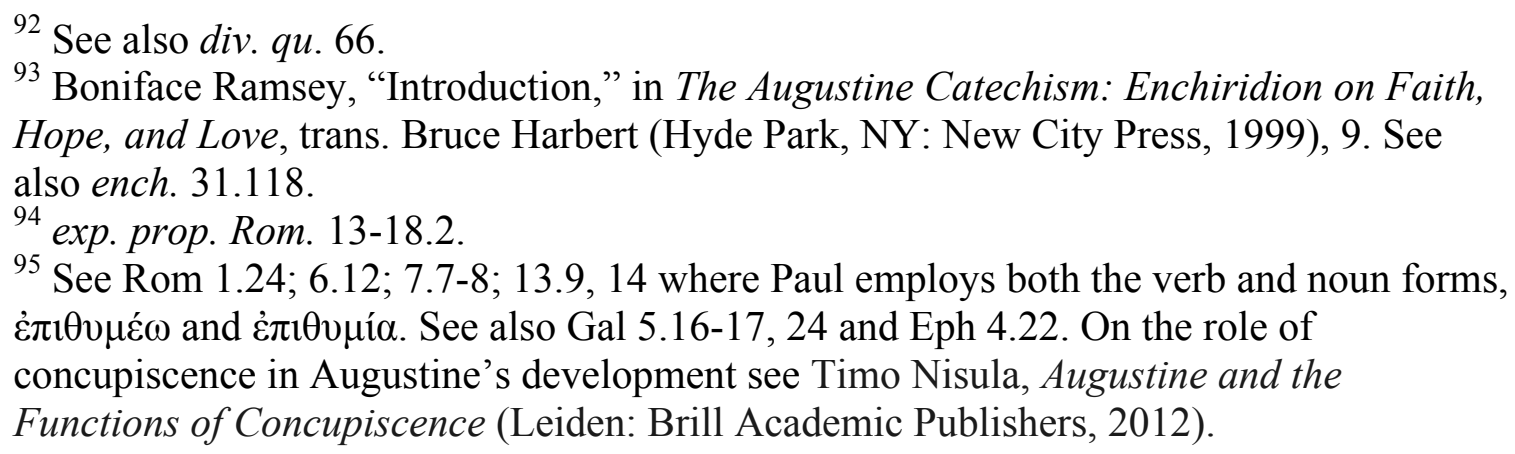
Hope, and Love, trans. Bruce Harbert (Hyde Park, NY: New City Press, 1999), 9. See also ench. 31.118.

94 exp. prop. Rom. 13-18.2.

${ }^{95}$ See Rom $1.24 ; 6.12 ; 7.7-8 ; 13.9,14$ where Paul employs both the verb and noun forms, $\dot{\varepsilon} \pi \imath \theta u \mu \varepsilon \dot{\varepsilon} \omega$ and $\dot{\pi} \pi \theta v \mu i ́ \alpha$. See also Gal 5.16-17, 24 and Eph 4.22. On the role of concupiscence in Augustine's development see Timo Nisula, Augustine and the Functions of Concupiscence (Leiden: Brill Academic Publishers, 2012). 
reason they follow the desires of the flesh is that their minds are in accord with their fleshly desires. Before the law is given, they do not recognize that the desires of the flesh are contrary to the Law of God. Without the law's guidance and instruction, they often have no reason to think that acting in accord with their fleshly desires is wrong. Until a human being receives the gift of the Law by which the mind assesses the good and evil of human desires, the rational soul can remain ignorant of which desires are sinful and thus willingly but unknowingly consent to sin.

Under the law, sub lege, human beings sin knowingly. Instructed by the law, they come to know themselves to be sinners and may even take pleasure breaking God's law. ${ }^{96}$ With the stronger sense of the freedom of the will in this early writing, human beings knowingly and intentionally violate the law and yet do so without approving of their own actions. By failing to follow ordinances which they know to be just and by desiring lesser goods, humans willfully do that which they know to be morally wrong. Such a person freely submits to and serves "depraved carnal desires" and emotions, all the while recognizing that in thought and deed these actions break the Law. ${ }^{97}$ Even when this person attempts to keep the law and to subdue the concupiscent flesh it is out of his or her own prideful resources rather than petitioning God's grace and mercy for help in avoiding sin. In this way, too, one sins willingly though without approving of the sin.

In both early and later writings, this second stage includes those who approach the law apart from God's grace and find themselves condemned by their works that violate the law. In these early writings the human in this stage freely wills not to believe, not to

\footnotetext{
${ }^{96}$ Augustine writes, "the fruit of a prohibited desire is sweeter," anticipating his famous discussion of the perverse pleasure of $\sin$ (exp. prop. Rom. 39). See also conf. 2.4.9. 97 exp. prop. Rom. 45-46.3.
} 
have faith, and thereby freely chooses to reject God's grace. By divine foreknowledge God knows who would will to believe and who would not. Those who would choose not to believe are not graced with the Holy Spirit by whose power those with faith are made capable of obedience to the Law. In later writings, God does not respond to the merit of foreseen faith. Rather, faith itself is a gift of grace and the reason some manifest faith and others do not is inscrutable. In this case, even the will to believe needs empowering by the gift of the Holy Spirit. Human beings are no longer free to choose whether to believe or not to believe. Regardless of whether faith merits grace or faith itself is the gift of grace, the early and later accounts equally hold that "sin overcomes him when by his own strength he attempts to live righteously without the aid of liberating grace."98 The human wills to resist sin but chooses means doomed to failure and thus is not capable of achieving the desired end. The human in the second stage either indulges in sin knowing it to be contrary to God's Law or wants not to be dominated by sin but both is incapable of bringing about this outcome and refuses the help of the One who can. The "man who is dominated by sin even though he wants to resist it, is still under the Law and not yet under grace." 99 The purpose of the law, then, is "to show what great and tight bonds of sins bound those who presumed to attain righteousness by their own strength,"100 and "to reveal sin before grace."101 Both those who are before the law and those who are under the law are seeking enjoyment and righteousness apart from God's grace through faith. Importantly, as Augustine examines the human condition in these first two stages he has no need to refer to the image of God. Recourse to the image of God is not necessary to

98 exp. prop. Rom. 44.

99 exp. prop. Rom. 32-34.5.

100 exp. prop. Rom. 30.

101 exp. prop. Rom. 36. 
explain concupiscence and sin before grace, either before the law or under the law, because in 395 Augustine still believes that human beings under the law have lost and have not yet been remade to the image of God.

The third stage, under grace [sub gratia], characterizes those who "implore the aid of the liberator." In this stage the image of God is introduced into Augustine's discussion of the four stages. The image of God is remade in the transition to the third stage and renovated and renewed as the human progresses through this stage. Augustine's gloss of Rom 6.6 invokes the renewal of the new man in Col 3.10 - "We know that our old man was crucified at the same time in order to cancel the body of $\sin .$. For as the crucifixion of the old man was symbolized by the cross of the Lord, so the renewal of the new man was signified by the resurrection." 102 Significantly, Augustine emphasizes that this renewal of the new human has two terms: not only the mind but also the body is renewed. The renewal of the mind takes place in the third stage whereas the renewal of the body awaits the fourth. The resurrection therefore signifies that although fleshly desires and temptations persist in this life, with the help provided by God's grace, the rational soul no longer consensually serves or obeys mortal flesh.

The third stage thus refers to the period of the spiritual renewal of the inner human, "when man in his mind now serves the Law of God, even though his flesh serves the law of sin." ${ }^{\prime 103}$ Such a person is "spiritual" with respect to their mind while very much remaining under the effects of the sinful nature with respect to their bodies. ${ }^{104}$

"Therefore I myself serve the law of God with my mind, but with my flesh I obey the law of sin" (Rom 7.25). Though his carnal desires still exist, by

102 exp. prop. Rom. 32-34.2.

103 exp. prop. Rom. 35.1 .

${ }^{104}$ exp. prop. Rom. 41.1. 
not consenting to sin he does not serve them who, constituted under grace, serves the Law of God with his mind even though with his flesh he serves the law of $\sin .{ }^{105}$

For all the hardship and suffering it brings, the troublesome disobedience of the flesh in this life turns out to be a divine blessing. First, it is a useful tribulation insofar as it provokes and reminds the believer of his or her creatureliness. Suffering reminds the creature that it is made ex nihilo and ought to turn away from nothingness - crucifying "the flesh with its vices and appetites" "106 — and toward its Creator from which it derives its being, life, and enjoyment, praying and relying upon God's grace for its healing in this life. Second, tribulation is useful for nurturing one's hope and desire for the future life, "the fourth stage of complete and perfect peace and eternal rest, utterly free of contending corruption and anxious vexation." 107 The elect, those who are predestined to arrive at this fourth stage, endure the tribulations of this world as a providential gift and useful means toward the renewing of their minds. Augustine cites Rom 8.29 approvingly in this veinSince those whom he foreknew he also predestined to be conformed to the image of his Son. ${ }^{108}$ At this point in Augustine's development, the conformation to the image of the Son indexes both the renewal of the mind in this life - as was the case in De moribus ecclesiae catholicae - and also the resurrection of the body in the next.

In opposition to those who would contest the justice of divine predestination - the election of believers and condemnation of the unbelievers-Augustine argues that anyone not under grace cannot understand God's justice because of their hardened hearts.

“Everyone desiring to know God's counsel should first be received into his friendship, a

\footnotetext{
105 exp. prop. Rom. 45-46.6.

106 exp. prop. Rom. 32-34.5. See Gal 5.24.

107 exp. prop. Rom. 53.21.

108 exp. prop. Rom. 55.3.
} 
possibility only for spiritual men already bearing the image of the heavenly man."109 Here, the heavenly man refers to those who are remade in their minds and thus exist in the third stage. Later, the referent of the image of the heavenly man will be transferred to the resurrected body of the fourth stage. For now, Augustine observes that only those in the third stage can understand the logic of election due to their being renewed to the image of God, that is, the renewing of their minds. Only then, "with the outer man destroyed [corrupto] and the inner man renewed [renovato], you might be able ... to know even the overpowering knowledge of the love of God." ${ }^{110}$ Once again, the image of the heavenly human (1 Cor 15.49), the inner human (2 Cor 4.16), and the new human (Col 3.10) together refer to the same dynamic of progressive renewal, in this case in the third stage of humanity. ${ }^{111}$ This grouping of metaphors is a continuation of what we found in De moribus ecclesiae catholicae as well as other works from this slightly later period. $^{112}$

In the fourth stage, in peace [in pace], the soul is no longer embodied in the sintainted and mortal flesh of this life but has received the immortal, spiritual body like that which Christ received in his resurrection. ${ }^{113}$ It is not until the human receives a resurrected body like that of Christ's that it will be possible to see Christ as he is, that is, face to face. This is the body in which humans will experience the beatific vision to

109 exp. prop. Rom. 62.20 .

110 exp. prop. Rom. 62.22.

111 See exp. prop. Rom. 24, 32-34.2, 62.20, 62.22.

${ }^{112}$ For example, "As long as we bear the image of the earthly man, then, that is, as long as we live according to the flesh, which is also called our old self, we experience the necessity of our habit so that we do not do what we will" (c. Fort. 22). Similarly, div. qu. 51.1 ascribes to the outer human the body, death, former/old, sinful, and image of the earthly man and ascribes to the inner human the soul, resurrection and renewal, new, righteous, and image of the heavenly man.

${ }^{113}$ See c. Adim. 12.4. See also civ. 19.10-17; 21.15; 22.29. 
which Augustine refers citing $1 \mathrm{Jn}$ 3.2-It has not yet appeared what we shall be, but we know that when he appears, we will be like him, for we shall see him face to face. ${ }^{114}$ No one attains this vision in its perfection this side of death, not even those who might perfectly keep the Law of God with the aid of divine grace.

Paul now points to the fourth of those four stages which we distinguished above. But one does not reach this stage in this life; it pertains to that hope by which we await the redemption of our body, when this corruptible and mortal thing will put on incorruption and immortality. Then is there perfect peace, because the soul endures no troubles from the now revivified body changed into a heavenly quality. ${ }^{115}$

The incorrupt and immortal spiritual body is the second term signified by the resurrection in Paul's discussion of the renewal of the human being. Those who live under divine grace in this life, in the third stage, have received the spirit of adoption with respect to the mind. They do not yet receive the spiritual body that all the children of God will possess in the resurrection.

This adoption, already established for those who have believed, was accomplished only spiritually, not physically. For the body has not yet been remade by that heavenly transformation, as the spirit has already been changed through the reconciliation of faith, having been turned from its errors to $[a d]$ God. ${ }^{116}$

Finally, in the fourth stage, the human being receives the spiritual body like that of the resurrected Christ in which there is no concupiscence-it submits perfectly to the mind that, in turn, perfectly submits to and enjoys its vision of God.

The implications of this fairly simple four-stage heuristic are easily confused, so a few brief observations are worth keeping in mind as one works with its taxonomy. First, the "four stages" is as much about transitions - in the relationship between the free will

\footnotetext{
${ }^{114}$ See exp. prop. Rom. 53.7.

115 exp. prop. Rom. 55.1.

116 exp. prop. Rom. 53.20.
} 
of the rational soul and the concupiscence of the flesh with respect to the law and to grace - as it is about the individual stages themselves. These three transitions are the giving of the law, conversion, and the resurrection of humanity. Second, although the four stages apply both to the history of an individual and to the history of humanity, the four stages are not a progression through which every person must go. Augustine points this out in several ways. For example, although the first stage, before the law, maps onto human history as the period from Adam to Moses, it is also appropriate to say that Adam, as an individual, is "under the Law" after God commands Adam regarding the forbidden fruit. ${ }^{117}$ Also, some people, like Abraham and baptized infants, might pass from the first to the third stage without entering the second. ${ }^{118}$ Third, the division between the first and second stage ought not be confused with that between a pre-Fall and post-Fall humanity. The first stage, before the Law, includes the pre-Fallen state but is not limited to this, given its reference to the period from Adam to Moses. For the same reason, the second stage, under the law, does not characterize all of fallen and unregenerate human beings. Fourth, the law does not characterize only the second stage. The law is introduced in the second stage but persists in the third and fourth. Those in the third stage are "with the law" rather than "under the law" - their fleshly desires persist but the mind is freed from consenting to them. And, in the fourth stage, those with spiritual bodies perfectly keep the law in the peace of their minds, no longer needing to subdue the rebellion of bodily lusts and appetites. Fifth, those in the first stage and second stage are both presented with mutually exclusive paths of seeking righteousness, faith and works. Those in the second

\footnotetext{
${ }^{117}$ See exp. prop. Rom. 29.

${ }^{118}$ See exp. prop. Rom. 20-21. See also ench. 31.119-120: "Some have never known that second state of servitude under the law but begin to receive God's help when they receive his commandment" (31.119).
} 
stage have the added benefit of the law by which sins are multiplied and by which to recognize their own depravity and incapacity (in and of themselves) to do works of righteousness. Likewise, in his early presentation, humans in both the first and second stages have the same possibility of freely willing to receive God's grace that would bring about their transition by grace into the third stage. Sixth, just as the transition to stage two introduces the law that persists, so also the transition to stage three introduces a grace which persists. That is, the human being's entry into perfect peace and the beatific vision is not due to them by virtue of their healed creaturely nature. Grace remains operative in the fourth stage as the gift of the Holy Spirit provides the love with which human beings in their spiritual bodies are enabled to see the Son of God as he is. ${ }^{119}$

${ }^{119}$ See 1 Jn 3.2. 
I.4 The Bishop of Hippo Confesses a New Image of the Trinity (396-400)

Much of Confessiones presents a flashback to Augustine's understanding of the image of God while still a Manichean. Under the influence of their "lies," Augustine recalls seeking God through his carnal inclinations rather than through his mind. ${ }^{120}$ His spiritual autobiography recounts many discoveries and guides the reader in making them the reader's own. In a time when there was much about God, the image of God, and himself that he did not know, it was God's mercy alone that would lead Augustine to seek that which is highest within himself rather than among external things or cultural norms. Augustine did not yet recognize at that point that "You were more intimately present to me than my innermost being, and higher than the highest peak in my spirit."121 He did not know then that evil is nothing but the diminishment of good to the point where nothing at all is left. ${ }^{122}$ He did not yet know that God is spirit and not a being with arms and limbs or what in the human justifies "saying that we are made in the image of God." ${ }^{123}$ He did not know that true inward righteousness takes as its criterion not customs of the day but the most righteous Law of God, that although morality is a changeless law it nevertheless takes a distinct form in every time and place, that understanding morality in an alien culture therefore requires accounting for the "frame of reference" of that particular context. ${ }^{124}$ Much from the litany of what he did not know appears in his several responses to Manichees during this period in which Augustine moves beyond merely defending the "image of God" term to deploying it within aggressive critiques of his opponents.

${ }^{120}$ conf. 3.6.11.

${ }^{121}$ conf. 3.6.11.

${ }^{122}$ See c. ep. Man. 37.42.

123 conf. 3.7.12.

${ }^{124}$ conf. 3.6.13. 
In Contra epistulam Manichaei quam vocant fundamenti (396), for example, Augustine takes up the question of evil in relation to the incarnation and the rational soul. Evil is not a nature, but a corruption of nature, a deficiency or diminution of the good. After the Fall, all human beings experience this corruption, and it is in order to heal the corruption of evil that the incarnation takes place. In the incarnation God's incorruptible nature assumes a corruptible, though not sinful, human nature. "The one true teacher, the incorruptible truth, the sole interior teacher... He also became exterior in order to call us back from exterior things to interior ones." 125 The Son of God-the Mediator between God and humanity — was equal to God in the form of God and a servant to God in the form of a man. Natures that can be corrupted were not begotten of God [de Deo], as was the Son, but were made by him from nothing [ex nihilo]. ${ }^{126}$ Only that which is begotten of God is incorruptibly good. Jesus Christ "was human for the sake of human beings, and he was God concealed in that manhood." ${ }^{127}$ He assumed an "entire human nature-spirit, soul, and body"128 — and although omniscient, knowing all along how his life would end, he endured to give an example of fortitude to his followers. God could have found another way to liberate humanity than by the incarnation, but this way presents to human beings a visible example and model to imitate. ${ }^{129}$

When Augustine learned that the Catholic Church did not believe, as the Manichees had alleged, that the creation of human beings in the image of God meant that

125 c. ep. Man. 37.42 .

${ }^{126}$ On the distinction between ex nihilio, de nihilo, and de Deo in Augustine's writings see Matthew Drever, Image, Identity, and the Forming of the Augustinian Soul (Oxford: Oxford University Press, 2013), 58-62.

127 en. Ps. 63.

128 agon. 18.20 .

129 agon. 11.12. 
God was understood to be determined by the form of a human body, Augustine did not yet have a notion of a spiritual substance. Augustine learned to confess by faith, "In no sense is our bodily form to be attributed to you, yet you have made us to your own image," even though, "I did not know how your image could subsist." ${ }^{130}$ Confessing this faith and striving to understand a substance not visible to the eyes, he came to conceive of God as necessarily imperishable, inviolable, and unchangeable/ immutable. ${ }^{131}$

As long as I was submitted to you, my true joy was your very self, and you subjected to me all those things which you created below me. The happy mean, the central region where I would find salvation, was to preserve your image in me, serving you and subduing my body. ${ }^{132}$

The conception of a hierarchy in the chain of being or of natures and value is wedded in Augustine's thinking to the hierarchy of dominion and rule in which the image of God participates. The divine reason or the will of God is itself the eternal law that commands the preservation of the natural order, and a deed, word, or desire that is contrary to the natural order is a sin against the divine reason or will of God. ${ }^{133}$ In the natural order of being and of dominion, the image of God is penultimate, subordinate only to God. This metaphysical hierarchy of goods is basic not only to Augustine's theology of the divine image but also to his ethics.

In all of creation, there is nothing better than the rational soul: "how great a dignity God has bestowed upon you [rational soul] — that he, who alone has dominion over you by nature, has made other goods over which you might have dominion."134 The dominion proper to human beings, as bearers of the image of God, is not independent of

\footnotetext{
130 conf. 6.3.4-6.4.5.

131 conf. 7.1 .1 .

132 conf. 3.7.11.

${ }^{133}$ See c. Faust. 22.27.

134 conf. 3.37.43.
} 
but derives from God's own dominion and rule. And the evidence or fruit of right rule is that subjects receive their just deserts. "He who exercises dominion justly both by just rewards and by just punishments is revealed by the happiness of those who live rightly and by the punishments of sinners." ${ }^{135}$ Where dominion is improperly exercised, resistance naturally follows. "Earthly things that obey teach you that you are their Lord, but insofar as they are troublesome, they teach you to obey your Lord."136 In large part, Confessiones is Augustine's own account of the struggle to subdue the rebellious passions of the flesh: "rearing up against you [God] in my pride ... those inferior things gained the upper hand and pressed me down."137 The rational soul remade in God's image finds itself in this middle space - between the rest of creation not made in the image of God and the God in whose image it was made - and from this place in the middle of things, its pursuit of knowledge of God and of itself follows a familiar process.

The inmost self knows that it is made by another through a procession of questioning from the bodily, material, and outer to the spiritual, immaterial, and inner realities. ${ }^{138}$ Augustine's third exposition of Gen 1, Confessiones Book 13, teaches that the knowledge of the Trinity in the rational soul begins with an explanation of natural phenomena. Augustine observes that a thing gravitates to its proper place as it is drawn by its own weight — for example, fire tends upward, stones downward, and water and oil separate and layer according to their weight. ${ }^{139}$ Dynamism, flow, or motion is evidence of deficiency and imperfection. Things are not at rest as long as they are disordered, and in

\footnotetext{
135 conf. 3.37.43.

136 conf. 3.37.43. See also c. Fel. 2.3.

137 conf. 3.7.11.

138 conf. 10.8 .9 .

139 conf. 13.9.10. Augustine's use of "weight" as a metaphor approximates what we might refer to as "fluid density."
} 
finding their rest they are brought into their proper order.

Building upon this account of the natural order, Augustine suggests that my weight is my love-wherever I am carried, it is this weight that carries me. This logic introduces a favorite conceptualization of Augustine's during this period in which human similarity or likeness to God is represented by the metaphor of distance or nearness. In a slight variation of earlier statements that we become conformed to that which we love, here Augustine adds the dimension of proximity to disposition and desire as they pertain to similarity and likeness. Those who draw near to God are those who are like God and vice versa. By turning to and loving the triune God I am made like God and carried up to the place for which I was created in the natural order of things.

Augustine tells us that no one perceives the triad of the trinity unless they are at rest in themselves in the entirety of their given nature-being, knowledge, and will. ${ }^{140}$ The human being is one life, one mind, and one essence, and yet the human individual must not confuse this unity with Being-Itself, God's substance which is, knows, and wills unchangeably. ${ }^{141}$ For all its nearness to God, the human soul does not know God in the same manner that God knows Godself. ${ }^{142}$ Once the soul controls and subdues the desire for and attachment to worldly things, and has begun to revive by living a good life, it is rewarded by God for its faith by being remade in the image of God.

We ought above all else to cultivate in ourselves this quality in which we excel the beasts, and somehow or other refashion it and chisel it afresh. But who ever will be able to do that, except the craftsman who fashioned it in the first place? We are able to distort [deformare] God's image in us, we are not able to restore [reformare] it. ${ }^{143}$

${ }^{140}$ conf. 13.11 .12 .

${ }^{141}$ On God's will as belonging to the immutable divine substance, see conf. 10.10.12.

142 conf. 13.16 .19

${ }^{143}$ s. 43.4 . 
The soul then continues to renew itself by considering truth and understanding it. ${ }^{144}$ Made new by God, the rational soul can understand God's truth without having to be taught by others. God teaches it to contemplate "the Trinity in Unity, the Unity that is Trinity" in whose image it is created.

Here, in an important revision, it is no longer the Son who is the image of God through and to whom humans are created. Rather, human beings are said to be created in the image of the Trinity. In this understated but immensely important innovation, Augustine does not draw the reader's attention either to the fact that this is an alteration of or addition to earlier expositions of the image of God. Augustine does advance an important claim - namely, that contemplation of the Trinity renews the human being with respect to the image of God according to which it is created. Previously the Son was the image and likeness of God, wisdom itself, truth itself. Human wisdom and truth participated in and was therefore like God the Son who was God's likeness itself, the form through whom and to whom the human was created. Confessiones Book 13 does not offer an explicit retraction of earlier descriptions of the Son as the likeness of God or as Truth itself or Wisdom itself. And yet, the exegetical exposition of "to our image" (Gen 1.26) no longer explains the image of God in terms of having been created to or in the Son who is himself the image and likeness of God. Instead, the pairing of "the plural with the singular — "Let us make" with "God made man in his image" and "to our image and likeness" with "in the image of God he created them" - is taken to indicate that it is precisely the Tri-unity of God, God's three-in-oneness that the human image of God

${ }^{144}$ conf. 13.22 .32 
reflects. ${ }^{145}$ Augustine does not come out and say of what this trinity consists, although the earlier triad of being, knowing and willing seems the most likely candidate in this context. ${ }^{146}$ This development in Augustine's understanding of the image of God-that human beings are created, remade, and renewed in the image of the Trinity rather than the image of the Son-is an important vista on the long ascent that is Confessiones.

One final and lesser discussed element of Augustine's writings on the image of God that emerges in this period is the analogy of the coin.

Tell us, then, what you think. Is it lawful to pay taxes to the emperor, or not?' But Jesus, aware of their malice, said, 'Why are you putting me to the test, you hypocrites? Show me the coin used for the tax.' And they brought him a denarius. Then he said to them, 'Whose image is this, and whose title?' They answered, 'The emperor's.' Then he said to them, 'Give therefore to the emperor the things that are the emperor's, and to God the things that are God's.' When they heard this, they were amazed; and they left him and went away (Mt 22.17-22). ${ }^{147}$

A refrain more common to his sermons, Johannine homilies, and writings on the Psalms, the comparison of the image of God in human beings to the image of Caesar on the coin does not occur in any of the Genesis commentaries, Confessiones, De Trinitate, or De civitate Dei. When the coin is made it has the image of its ultimate authority and rightful possessor stamped or impressed upon it. However, this image can be rubbed off or distorted by human $\sin .{ }^{148}$ God's desire is to receive back from the human that which is rightfully God's — namely, the soul that loves God and bears God's image. ${ }^{149}$

${ }^{145}$ conf. 13.22.32. This is not a simple replacement of "Son" with "Trinity" as the "God" term in the image of "God." Previously Augustine argued that human beings are created to the Son who is the "image and likeness of God." In Confessiones, however it is not yet clear whether Augustine wants to propose that the human being is [est] an image of the Trinity, is created to $[a d]$ the image of the Trinity, and/or is created to [ad] the Trinity. ${ }^{146}$ My speculation here comports with civ. 11 but not the later exposition in Trin. 8-15. ${ }^{147}$ Cf. Mk 12.13-27; Lk 20.20-38. See en. Ps. 63 and 94, and s. 72 and 308A.

148 s. 60, Io. ev. tr. 40.

${ }^{149}$ s. $113 \mathrm{~A}$, Io. ev. tr. 41. 
I.5 The Image of the Trinity and the Image of God in Christ (401-412)

The shift in the referent of Gen 1.26 from the Son to the Trinity evident in Confessiones 13 provides a catalyst for reconceiving the image of God. In the years during Augustine's fourth exposition of Genesis, De Genesi ad litteram, numerous developments unfold. Two major revisions occur where Augustine considers biblical texts in which veiling and unveiling provide the catalyst in which references to the image of God appear. Both De opere monachorum (401) and De spiritu et littera (412) examine the veiling of the Jews by the law and its implications for understanding the image of God references in 1 Cor 11 and 2 Cor 3.

We have seen that the appropriate magnitude of one's love for others corresponds to how well they use the gift of the rational soul. ${ }^{150}$ In De opere monachorum Augustine adds that to the degree we love others, we will advise them the more earnestly. ${ }^{151} \mathrm{We}$ advise, correct, and rebuke one another out of love in the hope that others will do the same for us as we ourselves might benefit from correction. Reflecting on years of experience with his own and others' errors - the Manichees, under Ambrose, as a priest, and later as a bishop as well-Augustine has grown confident in his conviction that the correction of error is an arduous, complicated, and necessary task. Difficulties arise, in part, because although the moral law is eternal, its manifestations are always culturally conditioned - and, therefore, scriptural prescriptions and prohibitions cannot always be read immediately into one's present context but often require a spiritual reading of the text. In this work in particular Augustine opposes the error of long hair among monks on the grounds of 1 Cor 11.7.

\footnotetext{
${ }^{150}$ See sol. I.2,7

151 op. mon. 31
} 
On the face of it, 1 Cor 11.7 seems to suggest that the male human being is the image of God whereas the female is not_For a man ought not to have his head veiled, since he is the image and glory of God; but woman is the glory of man. ${ }^{152}$ Men ought to have short hair and women ought to have long hair because the male is the image and glory of God whereas the female is the glory of the male. Augustine suggests that long hair was acceptable in the time of the prophets as a sign that they humbly acknowledged the separation from God effected by human sin. Long hair was an outward sign of the great distance or dissimilarity between human beings and God. ${ }^{153}$

As a result of the incarnation, the apostles rightly teach that in the present age long hair is no longer appropriate for men, whereas the veil worn by Moses and the long hair of the prophets had been appropriate symbols of humility in relation to God's glory and righteousness. In the case of the scriptural teaching regarding long hair for men, here monks, the prohibition stands. The prohibition symbolizes that after the incarnation, in the age of the Church, the image of God is remade by faith in Christ. What then of woman as the glory of man, as distinct from man as the image and glory of God, and of their having hair as a veil? Augustine teaches that 1 Cor 11.7, like Gal 3.27-28_-"For all

${ }^{152}$ In De opere monachorum, although Augustine is comparing male and female with respect to their hair and head coverings, he quotes only the first half of 1 Cor 11.7-uir quidem non debet uelare caput, cum sit imago et gloria dei-eliding the contrastative phrase that fails to attribute the image to the woman- "but woman is the glory of man." When he next quotes this text, as we will see, he deals with the difficulty of the second phrase by utilizing a figural interpretation.

${ }^{153}$ Recall that, for Augustine, distance from God is a spiritual metaphor indicating a degree of dissimilarity or unlikeness with respect to righteousness and holiness: "As the human soul draws near, the inner person is recreated in God's image because in that image it was created from the first. This person had been far away to the extent that he or she had lapsed into unlikeness, for it is not by spatial intervals that we approach God or distance ourselves from him. By your unlikeness to God you have gone far from him; as you become like him, you draw very near" (en. Ps. 99). See also en. Ps. 94, s. 24, s. 47. 
you who have been baptized into Christ, have put on Christ. There is neither Jew nor

Greek, there is neither slave nor free, there is no male and female"154_applies spiritually to the interior human where there is no sex.

The admonition given to men about not covering the head is expressed in a corporeal figure, but the words indicate that the injunction is carried out in the mind where the image and glory of God exist. ... he declares where this image is when he says, do not lie to one another. Strip off the old man with his deeds and put on the new one that is being renewed unto perfect knowledge of God according to the image of Him who created him (Col $3.9-10) .{ }^{155}$

The command not to cover the head is carried out in the mind of both the male and female, even though the corporeal figure that is used to express this injunction remains binding on men and women externally as well. The male's short hair signifies the veil removed from the soul turned to God and remade in God's image, and the female's long hair signifies the humility and obedience proper to the human vis-à-vis God and the body vis-à-vis the rational soul.

Interpretations that that would understand 1 Cor 11.7 to teach that only man and not woman is created in the image and glory of God fail to grasp the spiritual meaning behind the otherwise meaningless corporeal representations. Both male and female human beings are created in and can be renewed in the image of God in their minds - as the mind loves and subjects itself to God's rule in the same way that it rules and dominates its own concupiscent body and non-rational portion of its soul. "What, therefore, in one person are mind and concupiscence-for the one rules; the other is ruled; the one dominates, the other is subdued - that in two human beings, man and

${ }^{154}$ quicumque in christo baptizati estis, christum induistis, ubi non est iudaeus neque graecus, non seruus neque liber, non masculus neque femina (op. mon. 32.40).

${ }^{155}$ op. mon. 32.40 . 
woman, is represented [figuratur] according to sex of the body." ${ }^{156}$ In their physical bodies, the male signifies the mind whereas the female represents "that part which can be called concupiscible." ${ }^{157}$ Where 1 Cor 11.7 reads, "A man indeed ought not to cover his head, because he is the image and glory of God, but woman is the glory of man," Augustine clearly takes the absence of a repetition of "image" as an implicit denial on Paul's part that woman bears the image of God but interprets this denial as a figural rather than literal one. Paul is not denying Gen 1.26-male and female he created them, in the image of God he created them - according to Augustine, but signifying that it is the concupiscible parts of the human nature that are denied a share in the mind's bearing of the divine image.

Having come to the conclusion in Confessiones that the image to which human beings have been created is not that of the Son of God alone but the Trinity as a whole, Augustine does not jettison the scriptural notion that the Son is the image of God. Instead, the place of the Son as the image of God begins to migrate toward a more eschatological signification. The resurrected Son of God in his spiritual body, as Christians in the next life will see him, becomes the referent of those texts in which the Son is spoken of as the image of God. Unlike any manmade image, the Son is rightly worshipped as God alongside God the Father. "No image of God is to be worshipped except that image that is what he is, and that image ought not to be worshipped instead of him, but along with him." 158 This image is not a creature, but "the Son of God, the Word

\footnotetext{
156 op. mon. 32.40 .

157 op. mon. 32.40. See also conf. 13.32.47, where Augustine clearly states that concupiscence involves not only the body but the lesser part of the soul. 158 ep. 55.
} 
through whom all things were made."159 Augustine tells his congregation: We believe and worship this One whom we do not yet see in this life. ${ }^{160}$ When we do see him, we shall be like him, because we shall see him as he is (1 Jn 3.2). In the meantime, we continue to purify our souls - they are not yet as beautiful as they shall be when we see Him. $^{161}$

The image of God lost and found

The production of De Genesi ad litteram, written between 400 and 412, spans the gap between the conclusion of Confessiones and the beginning of De civitate Dei. This was a time characterized by Eugene TeSelle as “a major transition in Augustine’s thought," for here Augustine states "more strongly than at any time before or afterwards, that man completely loses his participation in the Word, the Image of God, through sin." 162 This phase in Augustine's interpretation of the image of God is short lived. As we will see, already in De spiritu et littera (412), he reflects upon an alternative interpretation of what is lost in the fall and regained in regeneration to which he would remain committed and advance in later writings.

The longest of Augustine's expositions of Genesis, or of any comparable text for that matter, De Genesi ad litteram displays Augustine's patent for the speculative as he offers multiple interpretations of the biblical record in an attempt to disclose numerous "literal" meanings beneath the surface of what may be called a "plain sense" of the

\footnotetext{
159 ep. 55.

160 ep. 64.

${ }^{161}$ On the soul's future beauty, see ep. 64.

${ }^{162}$ Eugene TeSelle, Augustine the Theologian (New York: Herder and Herder, 1970), 258, 259 (emphasis TeSelle's).
} 
text. ${ }^{163}$ Shortly after his first attempt to read Genesis around 373, Augustine had found Manicheanism convincing enough to become a "hearer" in their tradition, and three decades later we find him still mounting arguments in opposition to their dogmas as he once again takes aim at the Manichean rejection of both the Hebrew Bible (especially Genesis 1-2.4) and the authority of the Catholic Church. This fourth exposition of Genesis takes particular aim at the pre-existence and transmigration of souls. The account of the image of God offered here exhibits impressive agreement with earlier writings, including the earlier arguments against Manichean errors regarding creation and the image of God. However, he also reaffirms and specifies the alternative position that he begins to develop after Confessiones 13 and De opere monachorum that revises the more neo-Platonist framing of an ascension "to $[a d]$ the image of God."

Book 1 announces Augustine's intention to present "a great variety of possible meanings to the words of the book of Genesis"- a method of exposition also advocated in De doctrina Christiana. ${ }^{164}$ However, he is not content merely to multiply meanings. Among a "vast array of true meanings ... we should pick above all the one which can certainly be shown to have been held by the author we are reading."165 Throughout, Augustine's primary interest is what "the writer is most likely to have meant."166

Book 3 shows an observation initially made in Confessiones has stuck-the human created in the image of God presents an image of the Trinity. "Let us make" insinuates the plurality of persons, "not gods in the plural, but to take Father and Son and Holy Spirit — the trinity on whose account it says to our image — as being one God, on

${ }^{163}$ See doct. Chr. 2.1.1-7.11.

${ }^{164}$ Gn. litt. 1.20.40.

165 Gn. litt. 1.21.41.

${ }^{166}$ Gn. litt. 1.21.41. 
whose account it says, to the image of God." ${ }^{\text {167 }}$ Augustine predictably reprises earlier observations about the context of the image of God vis-à-vis dominion in Gen 1.26-28, adding a harmony of Col 3 and Eph 4 that suggests further warrants for associating the image of God with the mind or rational soul.

He immediately added, and let him have authority over the fishes of the sea and the flying things of heaven and of the other animals which lack reason, giving us to understand, evidently, that it was in the very factor in which he surpasses non-rational animal beings that man was made to God's image. That, of course, is reason itself, or mind or intelligence or whatever other word it may more suitably be named by. That is why the apostle says, Be renewed in the spirit of your minds and put on the new man, (Eph 4.23-24) who is being renewed for the recognition of God according to the image of him who created him (Col 3.10), where he makes it plain enough just in what part man was created to God's imagethat it was not in the features of the body but in a certain form of the illuminated mind. ${ }^{168}$

By now, the convictions expressed here have for the most part solidified: human beings are different from all other animals in that they possess rational capacities lacking in all other animals; the image of God refers to this difference between human beings and other animals; Eph 4 and Col 3 are harmonized to substantiate the mind as the locus of the image of God; and the rational soul, and not the body, is that by which human beings tame or exercise authority [potestas] over non-human animals.

More extensively than in his earlier expositions, in De Genesi ad litteram Augustine entertains potential objections and alternatives to his proposed readings. Genesis $1.26-27$ ought not be interpreted as if it were only the rational soul and not also the body that were created at this time, since only the human body can be male and female whereas both equally possess a non-sexed rational soul. Human creatures could only have been made male and female with respect to the body, since both possess a

${ }^{167}$ Gn. litt. 3.19.29.

${ }^{168}$ Gn. litt. 3.20.30. 
rational soul. Still, if the proposed spiritual reading of Gen 1.26-27 mistakenly rejects the literal creation of the male and female with their bodies, there is a grain of truth in the suggestion that the male suggests one aspect of the rational soul and the female another:

There may be the most subtle arguments, to be sure, about the actual mind of man in which he was made to the image of God, that its activity as a kind of rational life is divided between the contemplation of eternal truth and the management of temporal affairs; and that in this way it was made, as it were, male and female, with the former function directing, the latter conforming. With this division of roles however, that part alone is rightly said to be the image of God which clings in contemplation to the unchangeable Truth. It was as symbolically representing this that the apostle Paul says the man alone is the image and glory of God, while the woman, he goes on, is the glory of the man (1 Cor 11.7). ${ }^{169}$

The division of the mind's activities into distinct functions or roles, and the assignment of the image of God to only one of those roles, adds yet another specification regarding what in the human the image of God indicates. This differentiation of roles comports with Augustine's interpretation of 1 Cor 11.7 in terms of a dominant and a subordinate part of the human soul in De opere monachorum and Confessiones. Once again, the female human being is the image of God, just as the male is - not with respect to the body, nonrational soul, or active part of the rational soul that manages temporal affairs, but - with respect to the contemplative part of the rational soul that fixes its attention on eternal, immutable Truth. In their being or nature, male and female are equally the image of God. In their function relative to one another, however, the male signifies the image of God whereas the female signifies the subordination of the active part of the mind to the part that contemplates God's eternal truth. Where an analytic distinction between these functions is made, only the latter function indexes God's image in the rational soul.

${ }^{169} \mathrm{Gn}$. litt. 3.22.34. Edmund Hill suggests that in the line of argument which follows, Augustine's implied interlocutor is the Donatist scholar Tychonius (See On Genesis, ed. Edmund Hill, WSA 9 [New York: New City Press, 2002], 237 n.33, 307 n.6). 
And so, although this external diversity of sex in the bodies of two human beings symbolizes what is to be understood internally, in the one mind of a single human being, still the female too, because it is simply in the body that she is female, is also being renewed in the spirit of her mind in the recognition of God according to the image of him who created that in which there is no male and female.... their bodily sex has a different symbolic signification, according to which man alone is called 'the image and glory of God'. ${ }^{170}$

Just as in the Genesis creation account both the human male and female are created to the image of God with respect to the rational soul, so too both male and female might be remade in God's image, experiencing the grace of the mind's renewal in this life. Here, Augustine's spiritual interpretation of 1 Cor 11.7 that had earlier explained the prohibition of long hair for monks is now put to work in opposition to an anti-literal and non-corporeal spiritual reading of Gen 1.26.

Book 6 similarly reiterates that the upright posture is an indication to the human that it is made in the image of God, that the body itself is not the image but is adapted to signify that the rational soul is the image ${ }^{171}$ The rational soul ought to aim itself upward "to look at what is most excellent in the spiritual realm, "in order to savor the things that are above, not the things that are on earth (Col 3.2)." In a new development, Augustine goes on to distinguish between ensouled and enspirited bodies, as well as between the enspirited body and the enspirited mind.

In the present life all human beings, including Adam, are ensouled bodies, whereas in the resurrection those who are with God will have enspirited bodies. Augustine also draws a new distinction between the use of the image of God in 1 Cor 15, on the one hand, and its use in Col 3 and Eph 4, on the other. 1 Corinthians 15.49-as we have borne the image of the earthly man, let us also bear the image of the heavenly

${ }^{170}$ Gn. litt. 3.22.34.

${ }^{171}$ Gn. litt. 6.12.22. 
man - is reinterpreted as a text distinguishing ensouled bodies in this life from enspirited bodies in the next, that is, from bodies bearing the image of the heavenly man, understood as the Son of God in the resurrected spiritual body. Here, putting on the image of the heavenly man - the image of God the Son-refers to putting on the spiritual body in the next life. 1 Cor 15.49 no longer refers to one's growth in virtue in this life-a gradual, quantitative renovation or healing of the sinful nature, increasingly progressing from one degree to another-but instead a statement about the instantaneous qualitative change that takes place in the transition to the spiritual body in the next life. Paul's exhortation to those still inhabiting ensouled bodies that they ought to bear the image of the heavenly man in this life does not suggest that the enspirited body is attainable in this life. Rather, it aims to encourage faith in this life so that enspirited bodies might be granted as a reward in the life to come. "We now bear the image of the heavenly man by faith, due to have in the resurrection what we now believe. But we have worn the image of the earthly man from the very starting point of the human race." ${ }^{\prime 12}$ Like Adam's, our present bodies are ensouled and remain so until the resurrection of the dead. The ensouled body remains under the curse of sin and deteriorates in this life. ${ }^{173}$

That something is renovated and renewed suggests a prior distortion or disease, that something original has been lost. "What we get back" in this life as we are renewed in the image of God is not an enspirited body but "the justice from which the man fell

\footnotetext{
${ }^{172}$ Gn. litt. 6.19.30.

${ }^{173}$ As in Epistulae 55 and 64, the spiritual body of the next life (the image of the Son of God) differs from the ongoing renewal of the rational soul (the image of the Trinity) that the human being pursues in this life. The spiritual body does not undergo renovation or renewal in this life because human beings never had an enspirited body to begin with, but rather, only an ensouled body.
} 
through sin." ${ }^{174}$ Justice, in this sense, names the rightly ordered desires characteristic of the enspirited mind which Adam lost in the fall. In the regeneration of conversion the human gets back the enspirited mind, remade such that the ordering of its desires gradually comes to approximate justice, harmony. The mind or rational soul is renewed in those who, having been remade in God's image in regeneration, continue to have the soul progressively healed by loving God and thus by being conformed to God in their minds. "We shall be renewed in the spirit of our minds (Eph 4.23), according to the image of him who created us (Col 3.10), which Adam lost by sinning." ${ }^{175}$ Augustine distinguishes more clearly than in earlier expositions between an initial transition — from a mind that is not remade in God's image to one that has been remade - and a subsequent progressive renewal. Interestingly, it is still the latter, the gradual renewal, to which he takes the old / new human distinction of Col 3 and Eph 4 to refer.

Unlike Adam, who had an enspirited mind and would have received an enspirited body had he not sinned, after the Fall human beings are born with neither. Adam's and Eve's pre-Fall bodies were both mortal and potentially immortal, able either to die or not to die. ${ }^{176}$ Post-Fall human bodies are merely ensouled, "dead" in the sense that death is a necessity - they are not able not to die. ${ }^{177}$ The resurrected enspirited body would become for Augustine the referent of all those texts that speak of the image of God in terms of the Son. Being remade in the image of the Trinity, on the other hand, pertains not to the body

\footnotetext{
${ }^{174}$ Gn. litt. 6.24.35.

${ }^{175}$ Even in this penultimate exposition of Gen 1, Augustine maintains that the image of God was lost without providing any qualifications. Shortly after this, spir. et litt. (412) would speculate that perhaps the Fall did not involve the loss of the image of God. Was it that Augustine had come to understand the Fall differently, to conceive of the image of God differently? And, why did he change his mind?

${ }^{176} \mathrm{Gn}$. litt. 6.25.36. "If he had not sinned he would have been able not to die."

${ }^{177}$ Gn. litt. 6.26.37.
} 
but only the rational soul. Where the Son is not specified in texts that invoke the image of God, Augustine generally takes the referent of the image of God to be not the enspirited body of the next life, but the image of the Trinity in the rational soul-either in this life (in the ensouled body) or in the next (in the enspirited body). ${ }^{178}$

This new reading of 1 Cor 15.49 and the distinctions between the ensouled and enspirited body and the non-enspirited and enspirited mind do not necessarily require any modification of Augustine's theory of the four stages of humanity, either as individual human beings or in the world-historical register. These distinctions do however relocate to which of the four stages and to which part of human nature 1 Cor 15.49 and other texts refer. Even more important, however, a sort of relativizing of stages one and two takes place as the ante legem / sub lege distinction is incorporated into a more fundamental (for Augustine) pre-Fall / post-Fall narrative of Gen 1-3.

A way of reconciling the two accounts of the four stages is simple enough once one redefines stage one as a pre-Fall state and relocates ante legem and sub lege as two sub-stages within a post-Fall stage two. ${ }^{179}$ In this way the four-stage progression thought to describe post-Fall human existence is maintained while a pre-Fall existence (state of integrity) is portrayed as an experience that is no longer available to those living after Adam's original sin. In the first stage, the image of God is stamped on the spirit of

\footnotetext{
${ }^{178}$ The exception here is his interpretation of $1 \mathrm{Jn} 3.2$ that Augustine continues to associate with the Son for some time before eventually transitioning to an interpretation in which he asserts that human beings will see the Trinity face to face. Of course, the first known use of the term trinitas is by Tertullian. It does not occur in the Christian scriptures. Biblical texts refer only to an "image of God" and an "image of the Son," never to an image of the Father, Spirit, or Trinity.

${ }^{179}$ This scheme works as an account of Augustine's individual or world-historical four stages, requiring some modifications where Augustine's pre-Fall Adam is taken into account. Of course, post-Fall humanity does not experience stage one.
} 
Adam's mind. In Paradise, Adam has an ensouled body, although in the inner human, in the mind, he is enspirited according to the image of God. ${ }^{180}$ The transition to the second occurs when this image is lost through $\sin .{ }^{181}$ This revised second stage includes both those who do not yet have the Law of God and those who live under the law. As before, the transition to the third stage occurs when the image of the Trinity is remade at the point of regeneration, when the mind is enspirited through the grace of justification. The apostles and all who are just remain ensouled bodies even as they live an enspirited inner life in which they are being renewed "for recognition of God according to the image of the one who created them" (Col 3.10). Having been remade in the transition to stage three, the renewal of the image of the Trinity progresses throughout the third stage as the enspirited mind subdues the old human of fleshly concupiscence and manifests the new human in works of righteousness and holiness. ${ }^{182}$ Finally, the perfection of the image of the Son of God in the resurrection marks the transition to the fourth stage in which the ensouled body of this life is replaced with the enspirited body fitted for the next. Only then will the human exist in perfect enjoyment of God in the certain peace and knowledge of not being able to sin.

On the whole, De Genesi ad litteram is in broad agreement with earlier writings. It adds distinctions between the enspirited and ensouled body and the enspirited and non-

${ }^{180}$ See Gn. litt. 6.28 .39

${ }^{181} \mathrm{Gn}$. litt. 6.27.38.

182 This does not mean that human beings are unable to sin. In this life, spiritual people can fall when tempted to sin. This understanding may represent a chastening of his earlier position that it was possible to attain perfection in this life. If moral perfection somehow were achieved in this life, it would certainly include an awareness that the perfection of one's spiritual but still corruptible mind remained vulnerable, liable to disturbances if the rational soul fail should fail in its vigilant restraint of the concupiscence of mortal flesh. That is, it would be a perfection lacking perfect peace, an idea that would not sit well with the Augustine of civ. 22. 
enspirited mind that offer some specification, but primarily this work collates reflections and judgments about the image of God already evident in other writings subsequent to the unfinished literal commentary of 393. One feature of the image of God that achieves greater prominence in this period, the capacity for moral judgment, does contribute to some of Augustine's more criticized speculations about the role of Eve in the garden and of women in general.

Augustine finds it highly unlikely that God would withhold from Adam the power of distinguishing good and evil in the Garden. He finds it more credible that Eve would have lacked this capacity. Reiterating that in the mind human beings are neither male nor female — both male and female are capable of the image of God-Augustine wonders if Paul fails to ascribe the image of God to Eve in 1 Cor 11.7 because Adam had not yet cultivated this moral capacity to judge good and evil in Eve's mind. "Perhaps she had not yet received what she was going to receive gradually as she came to recognize God under the guidance and management of the man." ${ }^{183}$ Even in the peace of the Garden, there was a subordination proper to male and female in which the male signifies the image of God in a manner that the female does not. Furthermore, Augustine suggests that what led to Adam's fall was not the lust of the flesh or being deceived by the devil, but a loving concern for mutual friendship with Eve. This love for Eve was a good desire, in itself, but occasioned Adam's sin when it became disproportionate to Adam's good desire for God - that is, when Adams' mind failed to rightly order Adam's good desires. 'I am convinced that in no way at all could he have been led astray by that serpentine trickery

${ }^{183}$ Gn. litt. 11.42.58. 
which took in the woman." 184 Possessing this moral capacity "for discerning and distinguishing between good and evil, that is between just and unjust," 185 or "to distinguish the true from false, the just from the iniquitous, "186 the enspirited mind of Adam was led to sin because of his disordered love for the concupiscent Eve. The image of God is lost when the mind allows its love for lesser goods to increase, disordering its loves, distorting the right ordering in which the highest good is loved with the greatest love and other lesser goods in proportion to their natures. Augustine's account of the Fall, of Adam and Eve's roles therein, and of its impact upon the image of God would change in short order.

In De spiritu et littera Augustine again examines the role of the Law in the life of the Christian, this time highlighting the role of the veil in 2 Cor 3 . He observes a difference between the Old Testament and the New Testament in that in the former the law was written on tablets of stone, striking fear in the people from without; in the latter the law is written in the minds and on the hearts of those whom God's spirit indwells, generating delight and pouring out love. ${ }^{187}$ The image of God is pertinent to this discussion where Augustine offers two interpretations of Romans 2.14, attempting to discern whether or not the Gentiles who do the works of the Law are regenerate. Both interpretations maintain that justification precedes observance of the law, and both work within the general contours of the four stages developed in the exposition of Romans. The question here is whether the Gentiles described are in stage two or stage three. In one proposed interpretation, the Gentiles "who do by nature what pertains to

\footnotetext{
${ }^{184}$ Gn. litt. 11.42 .59

${ }^{185}$ Io. ev. tr. 8.2.

${ }^{186}$ s. 374.

${ }^{187}$ See spir. et litt. 25.42 .
} 
the law and have the work of the law written in their hearts" (see Rom 2.14) are

regenerate Gentiles, those who have already been remade in the image of God.

Do not be concerned that he said that they do what pertains to the law by nature, not by the spirit of God, not by faith, not by grace. After all, the Spirit of grace acts to restore in us the image of God, the image in which we were created in terms of our nature. An injury that grace heals is surely against nature. ... human beings naturally observe what pertains to the law; those who do not do this fail to do it as a result of their woundedness. $^{188}$

Here we see Augustine's account of evil as a lack or deficiency of nature. Works that the Gentiles do by nature are not evil works, from a lack, but good works done by their good nature that is already in the process of being healed by grace. Such works are done by those in the third stage.

Augustine's second interpretation understands the Gentiles in question to be in the second stage, and yet Augustine entertains the possibility that these Gentiles too might possess the image of God. On this proposed alternative reading,

The image of God has not been removed from the human soul by the stain of earthly loves to such a point that not even the faintest outlines of it remain. Hence, the soul can be correctly said to observe or know some elements of the law even amid the godlessness of its life. Perhaps this is what the apostle meant when he said that the Gentiles who do not have the law do by nature what pertains to the law and that such human beings themselves are a law for themselves and have the work of the law written on their hearts. That is, what was impressed upon the soul by the image of God, when it was created, has not been entirely removed. ${ }^{189}$

In this case the text is speaking of non-regenerate Gentiles. Up to this point Augustine has repeatedly rejected the notion that unregenerate persons have the image of God. But now, Augustine offers a provisional alternative interpretation in which "renewal" refers to "what was not entirely destroyed ... The very image of God, which godlessness had

188 spir. et litt. 27.47.

189 spir. et litt. 28.48. 
not completely wiped out, [it] is renewed in the mind of those who believe through the New Testament." ${ }^{, 190}$ The renewal of the Law written on the heart is now a repair job of what had not been entirely erased, a task of which the external law written on tablets was incapable. This re-writing of the law in the mind and upon the heart constitutes justification. This second possible interpretation of Rom 2.14-in which the image of God is not lost—persists in Augustine's mature writings whereas the former possibility that had been Augustine's position for a decade disappears. Henceforth, the image of God is not destroyed, not completely defaced or rubbed out as in the coin metaphor. Instead, the image of God is already present in the human nature when the person comes to believe or have faith. How are we to explain the introduction of this new alternative interpretation of the effects of the Fall on the image of God after four expositions of Genesis and so many years? Several indications point to a particular biblical text as pivotal.

We find a first important clue in Retractiones where Augustine offers three scriptural warrants for teaching that the image of God is not lost:

For, if it had not lost anything at all, the condition would not have existed on account of which it was said, Be reformed in the newness of your mind (Rom 12.2), and, We are being transformed in the same image (2 Cor 3.18). But, if, on the other hand, all of it were lost, nothing would have remained so that it could be said, Although man walks in an image, yet he is disturbed in vain (Ps 39.6). ${ }^{191}$

Augustine takes these three biblical texts as evidence that the image of God was not lost.

We have already seen that somewhere between completing De Genesi ad litteram in 410 and writing De spiritu et littera in 412-413 Augustine began to entertain the possibility that what was lost in the Fall might not be the image of God. This period 190 spir. et litt. 28.48 .

191 retr. $1.26(25)$. 
coincides with the production of three works that quote and for the first time reflect upon how to interpret 2 Cor 3.18: Sermon 362, Epistula 147, and Epistula 148.

Augustine first quotes 2 Cor 3.18-We are being transformed into the same image from glory to glory, as by the Spirit of the Lord ${ }^{192}$ - in Sermon 362, where it is treated as a parallel of $1 \mathrm{Jn} 3.2$ and 1 Cor 13.12, both of which Augustine takes to be referring to post-resurrection existence: "that life will continue forever in the contemplation of truth, not only inexpressibly but delightfully."193 Augustine does not yet say anything about the "veiling / unveiling" that would become important to reconceiving the image of God vis-à-vis the unregenerate human.

Written shortly after Sermon 362, Epistula 148 provides a longer quote of 2 Cor 3.18 and reflects not only on the transformation in glory but also on the role that veiling plays_-But as we gaze upon the glory of the Lord with face unveiled, we will all be transformed in to the same image of him from one glory to another glory as if by the spirit of the Lord (2 Cor 3.18). ${ }^{194}$ Augustine again insists that this transformation in glory will take place in the mind's eye, in the inner human, and that it "will come about at the resurrection of the dead ... The testimony states the promise not of a present but of a future vision." 195 The veil spoken of here, however, has already been removed - it refers to that which was over the hearts of the Jews before the coming of Christ. Epistula 147 draws together these two discussions of 2 Cor 3.18 in Sermon 362 and Epistula 148.

Like De spiritu et littera, Epistula 147 addresses the question of veiling and

\footnotetext{
192 in eamdem imaginem transformamur a gloria in gloriam tanquam a domini spiritu. 193 s. 362.31 .

${ }^{194}$ ep. 148.2.7. nos autem omnes reuelata facie gloriam domini speculantes in eandem imaginem transformamur a gloria in gloriam tamquam a domini spiritu.

195 ep. 148.2.8-9.
} 
unveiling with respect to the Law of God in the Old Testament. Augustine once again takes the 2 Cor 3.18 text to suggest two transitions but, in contrast to Epistula 148, he also finds suggestions of a transformative process between these two events. The first transition is an event of unveiling that corresponds to regeneration. After regeneration, a transformative process "by which the interior self is renewed day by day" follows: "because the veil is removed when anyone crosses over to Christ, we are being transformed into his image with the veil removed." 196 The second transition marks a transfiguration in glory, an event that has not yet taken place but will occur in the resurrection that inaugurates the eschaton- "that is, from the glory of faith into the glory of eternal contemplation." 197 To repeat, the unveiling refers to the transition from lacking faith to faith's beginning in regeneration. Once the veil is removed, the renovation of the image of God in this life commences: "Because the veil is removed when anyone crosses over to Christ, we are being transformed into his image with the veil removed." 198 The subsequent transfiguration in the glory of the image of God refers, as in Epistula 148, to the transition from the glory of faith in this life to the future glory of eternal contemplation of God when we shall see God "face to face" (1 Cor 13.12). Thus, at this point in his development, Augustine takes 2 Cor 3.18 to refer to regeneration, the gradual renovation of the image of God, and a transition from its glory in this life to its glory in the next.

This flurry of interest in 2 Cor 3.18 helps to illustrate how Augustine's repeated interpretations of a biblical text have the potential not only to add to but also to

\footnotetext{
${ }^{196}$ ep. 147.22.51. See 2 Cor 4.16.

${ }^{197}$ ep. 147.22.51.

198 ep. 147.22.51.
} 
significantly revise earlier interpretations. Augustine's generative reflection on 2 Cor 3.18 in these writings takes place shortly before he revises his position regarding whether the image of God is lost in the Fall. The imagery of the removal of a veil from the mind in 2 Cor 3 suggests not that something lost has been returned, but, rather, that something already present has been uncovered, unveiled, and is now capable of displaying its features or enacting its capacity, becoming empowered "by the Spirit of the Lord" in regeneration.

Augustine's revised interpretation understands the image of God as already present prior to regeneration. On this reading, its proper glory cannot be seen so long as the mind is not enspirited and the veil of the Law remains over it. It is precisely this imagery of veiling and unveiling in relation to the Law that Augustine is working with in De spiritu et littera where he suggests that perhaps the image may not have been lost after all. Augustine quotes extensively from 2 Cor 3.3-17 and discusses multiple other sources with respect to the image of God and yet does not quote 2 Cor 3.18 in De spiritu et littera. It is not until Retractiones that we receive from Augustine's pen an explicit appeal to 2 Cor 3.18 as a central text supporting his claim that the image of God is not lost in the Fall. Having begun De Trinitate long before writing De spiritu et littera, the finished product nonetheless manifests Augustine fully embracing his provisional interpretation of the Fall in which the image of God is not lost. As for 2 Cor 3.18, De Trinitate suggests that Augustine would remain open, at least in principle, to revising his interpretation of this verse in particular, and perhaps also his mature understanding of the image of God as well. ${ }^{199}$

${ }^{199}$ See Trin. 14.18.24; 15.8.14. 
I.6 The Image of God in Five Trinities and Four Stages (413-426)

Augustine begins De Trinitate around 400, but it is not until approximately 413 that his attention in this work turns in earnest toward the image of the Trinity in the rational soul. Augustine announces in Book 10 the conclusion at which he will arrive in Book 14 and for which De Trinitate is justifiably famous - the image of God in the human is the mind's remembering, knowing, and willing of itself. ${ }^{200}$ The mediating Books 11-14 serve to train "slower readers" to derive this conclusion for themselves. ${ }^{201}$ Along the way Augustine specifies five distinct trinities in the human, all of which are vestiges of the Trinity but only the last of which is the image of God. As Augustine guides the reader through the various trinities, the criteria that are used to indicate in what respects the first four trinities are not the image of God derive from metaphysical and theological commitments regarding divine ontology and Christology. Book 15 delivers on the original promise of distinguishing the generation of the Son from the procession of the Holy Spirit and does so by utilizing the image of God in the rational soul as an analogy. In the concluding remarks to Book 15, to which we will turn in Part II, Augustine attends carefully to the ways that the created image of God differs from the triune Creator as he draws an analogy between eternal generation of the Son qua Word and the generation of true words in the image of the Trinity, in the human mind.

\footnotetext{
${ }^{200} \mathrm{He}$ announces the goal of the exercise in Book 10: "We were in the process, you remember, of bringing the mind to light in its memory and understanding and will of itself" [Mentem quippe ipsam in memoria et intellegentia et voluntate suimet ipsius talem reperiebamus] (Trin. 10.14.19); And, he reminds the reader when they arrive at the intended destination in Book 14: "Here we are then with the mind remembering itself, understanding itself, loving itself. If we see this we see a trinity, not yet God of course, but already the image of God" [Ecce ergo mens meminit sui intellegit se diligit se. Hoc si cernimus cernimus trinitatem nondum quidem deum sed iam imaginem dei] (Trin. 14.8.11).

${ }^{201}$ Trin. 14.7.10. See also Trin. 15.1.1.
} 
Books 11 through 14 develop five trinities, two trinities of the outer human (11) and three of the inner human (13-14). ${ }^{202}$ The outer human is that which the human has in common with the other animals created by God, both body and soul $[$ anima $] .{ }^{203}$ The inner human refers to the mind [mens]. The inner human or mind is the part of the intellectual or rational soul [animus] that is peculiar to the human, distinguishing both male and female humans from all non-human animals. In an "ascent from lower things to higher" that is simultaneously an "entrance from outer things to inner," Augustine's exposition of these five trinities proceeds in stages from outer, temporal, bodily senses to inner, immortal, spiritual wisdom. ${ }^{204}$

Before turning to these five trinities, we should note that De Trinitate is the one work in which Augustine cites all nine of the biblical references to the image of God dealt with in the pages above. Specifically, near its conclusion, Book 14.22-25 quotes eight of these biblical texts in an unprecedented confluence of the verses that have shaped his understanding of the image of God over the previous forty years. ${ }^{205}$ In this context, Augustine explains how the fifth trinity - the image of the Trinity in the human mindprogresses in the course of a human life. The only one of these nine biblical texts not

${ }^{202}$ Augustine describes two trinities - one of active knowledge and one of contemplative wisdom, differentiating the former genus from the latter in Book 12.

${ }^{203}$ Trin. 15.1 .1

${ }^{204}$ Trin. 14.2 .5

${ }^{205}$ I have not encountered any mention of this unique concentration of the biblical sources so important to Augustine's understanding of the image of God throughout his career in scholarship on Augustine's use of this concept. Apart from tracing his uses of these texts across his corpus (as I have done) it is not clear what would draw one's attention to this phenomenon. Augustine constantly resources biblical texts and $D e$ Trinitate is no exception. The unique aspect of Trin. 14.16.22-19.25 is that he deals, for the first time, with so many of the biblical sources in one place, locating each reference within his theological imaginary. This remarkable convergence is easy to miss amidst the many fascinating intricacies of Trin. 14 that capture one's attention. 
mentioned in Book 14, 1 Cor 11.7, is no less integral to De Trinitate's account of the image of God, as it provides the basis for a separation between the lower and higher trinities of the inner human in Books 12-15.

The trinities of the outer human

Book 11 examines both the bodily trinity of the outer human and the trinity of the soul in the outer human. The bodily trinity pertains to "sensible things that are seen with the eyes. ${ }^{, 206}$ Looking back from the vantage of Book 14 at what had been accomplished in the previous books, Augustine recalls that in Book 11, by examining the phenomenon of bodily sensation,

we found a first trinity in the body that is seen, and the gaze of the seer which is formed from it when he sees it, and the intention of the will which joins the two together... [in] the bodily trinity of vision the intention of the will joins together the form of the body that is being seen with the conformation to it that is being produced in the outer gaze by looking. ${ }^{207}$

This bodily trinity of the outer human signifies the divine Trinity and yet it cannot be said to be the image of God in the human. It is the trinity of the human that is least like God. Whereas the Trinity is homoousias, of one substance, this outer trinity consists of three distinct substances or natures - that of the sensing subject, the sensible object, and the will in the human mind.

Book 11 next considers the trinity of the soul of the outer human. When the body that is being seen is taken away from view, an image of it "remains in the memory, and in thought the inner gaze can be formed from it, with the will as the third element joining

\footnotetext{
${ }^{206}$ Trin. 14.7.10. See Trin. 11.2.2-5.

${ }^{207}$ Trin. 14.2.5.
} 
the two together." ${ }^{208}$ This second trinity of the outer human occurs internally insofar as it takes place within the memory, understanding, and will, whereas the initial trinity of bodily sense occurred partially outside of the mind. However, the fact that this trinity refers to a process by which external temporal things are brought into the mind through bodily senses, a process that is common to human beings and non-rational animals, shows that this trinity too is properly attributed to the outer human rather than the inner human (or mind) that distinguishes the human being from the non-human animals.

The trinities of the inner human: scientia and sapientia

Book 12 distinguishes between the two functions of the rational soul. It repeats the earlier teaching that the male and female are equally the image of God when considered individually. ${ }^{209}$ When considered as a unit— the two having become one flesh (Gen 2.24) - their gender roles once again signify two distinct functions of the rational soul.

Only in that part which is concerned with the contemplation of eternal things can one find something that is not only a trinity but also the image of God; while in the part that is drawn off for temporal activity one may perhaps find a trinity, but certainly not the image of God. ${ }^{210}$

As in De Genesi ad litteram Augustine turns to 1 Cor 11.7-The man ought not cover his head, since he is the image and glory of God. But the woman is the glory of man-to argue for a subordination of the two functions of the rational soul. And, again Augustine quotes Gal 3.28, Eph 4.24 and Col 3.10, to argue that Paul's concern in 1 Cor 11.7 must be read spiritually, not as a denial that the female is the image of God, but as an

\footnotetext{
${ }^{208}$ Trin. 14.2.5. See Trin. 11.3.6-4.8.

${ }^{209}$ See Trin. 12.12.19.

${ }^{210}$ Trin. 12.4.4.
} 
affirmation that the active knowing of the mind must submit to its contemplation of things eternal. ${ }^{211}$ Of these two functions of the mind, it is the latter that constitutes the rational soul as the image of God. For, it is specifically the mind's capacity for the recognition of God that Augustine now identifies as the image of God.

It is an idle and base kind of thinking which supposes that God is confined within the limits of a body with features and limbs. And does not the blessed apostle say, Be renewed in the spirit of your mind, and put on the new man, the one who was created according to God (Eph 4.23-24); and even more clearly elsewhere, Putting off the old man, he says, with his actions, put on the new who is being renewed for the recognition of God according to the image of him who created him (Col 3.9-10). ${ }^{212}$

Here it is not merely the old and new human that Augustine juxtaposes. Augustine's axiology in which perfection is tranquil and activity implies deficiency suggests that the actions of the old human, the very fact of activity itself, involves a deficiency in comparison to the recognition of God by the new human, a sort of contemplation of wisdom. Otherwise, this exposition differs from the earlier very little in what it affirms, and yet what is missing is quite significant. Most importantly, the image of God is not lost in the Fall and, thus, regeneration does not remake the image of God in the rational soul. The image of God in the rational soul is proper to all human beings, Catholic and pagan alike. Augustine also modifies slightly his earlier understanding of the signification of the female's subordinate function. Whereas De opere monachorum and De Genesi ad litteram held that the female signifies all of the non-rational faculties that are held in common with the beasts, De Trinitate suggests Paul had in mind only the non-rational faculties of the inner human, the mind's active knowledge, when he withheld the image of God from the female in 1 Cor 11.7. Following suit, in this later exposition Augustine

${ }^{211}$ Augustine draws upon Col 3.9-10 and Eph 4.23-24 in his expositions of 1 Cor 11.7 in both op. mon. 31-32 and Gn. litt. 3.19.29-22.34.

212 Trin. 12.7.12. 
specifically designates the serpent rather than the female as signifying the bodily concupiscence. ${ }^{213}$ Related to this development, Augustine modifies his account of Adam and Eve's original sin. No longer does he suggest that Eve lacked the moral capacity of discerning good and evil, nor does he explain Adam's fall as subsequent to Eve's or as a result of his loving concern for her. Instead, Adam and Eve ate together, Adam being equally complicit for consenting to and for omitting to curb Eve's deceived appetites. ${ }^{214}$ The active and contemplative functions of the mind are equally implicated in the Fall. A modest step toward an egalitarian account of male and female, to be sure, but a step nonetheless.

The two functions of the rational soul relate to distinct subject matters, two kinds of knowledge — scientia and sapientia. The subject matter of the first is creaturely whereas that of the second is divine. "Knowledge of things divine is properly called wisdom [sapientia], and of things human is properly called knowledge [scientia]."215 To wisdom he assigns knowledge of the divine being and attributes. ${ }^{216}$ Knowledge of human things, on the other hand, includes "anything that breeds, feeds, defends, and strengthens the saving faith which leads to true happiness. ${ }^{, 217}$ The lower trinity of the inner human is that by which the human exercises moral judgment. This capacity was possessed equally by the male and female in the Garden. Unlike the anima, the soul of non-rational animals, the animus, the human rational soul, possesses a moral capacity to discern good from evil

\footnotetext{
${ }^{213}$ Trin. 12.13.20.

${ }^{214}$ Trin. 12.12.17.

215 Trin. 14.1.3.

${ }^{216}$ The discussions in Books 14 and 15 consider the divine attributes, first, as they are evident in the created trinity that is the image of God and, second, as they are distinct in creaturely image of God as compared to the Trinity that is the Creator.

${ }^{217}$ Trin. 14.1.3.
} 
in order to act rightly.

Significantly, knowledge of the incarnation itself falls within scientia, the subject matter of things human rather than divine. As part of the knowledge of faith, knowledge of the incarnation - not merely the birth but the entirety of Christ's life through to the ascension - is considered human rather than divine for three reasons, each of which has to do with temporality. First, the knowledge of faith is temporal because the subject matter itself is not coterminous with the knowing subject, the human mind. The incarnation precedes - in human history — the mind whose faith reflects upon this event. Second, the knowledge of faith is adventitious to the human mind - that is, it comes into existence or ceases to exist at a point in time that is not coextensive with the existence of the mind itself. The mind that learns to have faith in the incarnation already exists prior to its coming to have this faith. We will return to this point shortly. Third, and most importantly, God's economic work of salvation occurs temporally in the world. The first two elements highlight that one's faith in the incarnation is itself a temporal phenomenon. The third element alone, however, the temporality of the incarnation itself, is sufficient to locate it on the knowledge side of Augustine's scientia/sapientia distinction.

In the incarnation it is not the being of God that is known. God's being is eternal, non-corporeal, simple, impassible, and immutable. That which God does in Christ is temporal, bodily, composite, and involves suffering and change. Of the two collocations of attributes it is the latter that pertains to the knowledge of faith whose subject matter is the work of Christ: "All these things that the Word made flesh did and suffered for us in time and space belong, according to the distinction we have undertaken to illustrate, to 
knowledge and not to wisdom." ${ }^{, 18}$ Likewise, "that power [or function] of the inner man by which he reasons about temporal things ... the lower function which includes the salutary knowledge of human affairs which we need in order to act in this temporal life in a way that will gain us eternal life" is not the image of God, but the lesser trinity of the inner human. ${ }^{219}$ In the future beatific vision, it will not be the obedience and humility of the incarnation that one will contemplate. Rather, it will be the immanent Trinity itself with its eternal processions, in whose image the human was created, that the rational soul will then contemplate.

Although distinct, human knowledge and human wisdom are related. "Faith in the temporal things, which the eternal one did and suffered in the man he wore in time and bore through to eternity," is a precondition of the temporal virtue needed for that eternal life in which human wisdom will participate perfectly in divine wisdom. "The very virtues by which one lives sagaciously, courageously, moderately, and justly in this time of mortality must be related to this faith which though temporal itself leads to eternity, or they will not be true virtues." ${ }^{220}$ Faith in the person and reconciling work of Jesus Christ is the way that leads from temporal knowledge to eternal contemplation. Faith is a necessary precondition for the proper exercise of the moral capacity.

\section{Two trinities of faith}

Having already distinguished a lower and higher trinity of the inner human according to function and subject matter, Augustine proceeds to divide the lower trinity

\footnotetext{
${ }^{218}$ Trin. 12.15.24.

${ }^{219}$ Trin. 14.7.10.

${ }^{220}$ Trin. 14.1.3.
} 
as it exists in faith and hope in this life from its existence in the mode of remembrance in the next life after the resurrection. ${ }^{221}$ The first trinity of knowledge in the inner humanthe mind's remembering, knowing, and loving — has as its object the faith with which it knows God's work ad extra, from the perspective of the human in the temporality of the creation. "In his retaining, contemplating, and loving of this temporal faith there is not such a trinity as deserves to be called the image of God, even though he is living according to the inner man; otherwise he would appear to be setting up this image in temporal things, although it should only be set up in things that are eternal." ${ }^{, 22}$ This knowledge of things human is a faith that will itself pass away-when and where that which once was unseen becomes seen, faith no longer exists - for, faith is being sure of what is hoped for and certain of what is not seen. ${ }^{223}$

A second trinity of knowledge in the inner human also deals with temporal knowledge, but from the vantage of life after the resurrection. This second trinity is also a trinity of faith and it also is not yet the highest trinity of the inner human that is the image of God. It differs from the first trinity of faith within the inner human in a manner

\footnotetext{
${ }^{221}$ The presentation I provide of the third and fourth trinities, both trinities of faith, is nearer to Augustine's in Book 14 than his presentations in Books 12 and 13. In the earlier books, the two lesser two trinities of the inner human are not distinguished as much by a temporal division - i.e., of looking forward or back relative to the transition that will take place in the resurrection. In Books 12 and 13, a greater emphasis is placed on a not very well defined distinction of subject matter in one's temporal knowledge. Trin. 15.6.10 presents yet another list of five trinities that distinguishes the third and fourth trinities in manner that does not map onto the one provided in Trin. 14.2.4-5. There, distinct objects of knowledge are again foregrounded: the third trinity is evident "when things that spring up in the consciousness like faith, like the virtues which are arts of living, and perceived directly by reason and grasped by knowledge;" the fourth trinity is evident "when the mind itself, by which we know whatever we can say we truly know, is know to itself or thinks about itself" (Trin. 15.6.10).

${ }^{222}$ Trin. 14.2.4.

${ }^{223}$ See Heb 11.1.
} 
analogous to the differentiation of the two outer human trinities. ${ }^{224}$ Sensible vision in the first trinity of the outer human corresponds to temporal faith in the first trinity of the inner human. Each of these first trinities deals with a triad that ceases to exist when the initial term - the body seen in the one case and faith in the incarnation in the other-is no longer present as the object of the mind's active remembering, understanding, and willing. When the sensible object seen is removed from the outer gaze, a second trinity is formed as the image impressed on the memory by sensible vision becomes the object of the inner gaze. Likewise, in the eschaton, faith—as knowledge of things unseen — will no longer be the means of knowing Christ even as this faith is retained in the mode of remembrance, since the things previously known (by faith) as unseen will there and then be known as seen. ${ }^{225}$ This second trinity of the inner human will not be experienced until the resurrection of the body. In that future, spiritual, resurrected body, temporal faith will no longer exist as something present, but will only exist in the mode of remembranceremembered, understood, and willed by the person who will then be experiencing the vision of the Trinity for which that faith had, during one's bodily life, been waiting in patient anticipation.

Therefore, the inner human's lower trinity of active knowledge — constituted by remembering, understanding, and loving God, itself, and all things by faith — is not the image of God. Nor will it be the image of God in the eschaton when its knowledge regarding God's temporal work of salvation in the incarnation will be perfectly known. "The trinity which does not yet exist will no more be the image of God than this trinity

${ }^{224}$ Trin. 14.2.5.

${ }^{225}$ See 1 Cor 5.6 . 
which will not then exist." 226 One reason that these trinities are not the image of God is that neither trinity under consideration coincides with the mind's existence - the first trinity (temporal faith) ends with the resurrection, whereas the second trinity (looking back on one's faith) begins only with the resurrection. These trinities that either arise or cease to exist at the resurrection (or any other moment) are not coterminous with the mind's nature and-because the image of God is in the mind both before and after the second coming — cannot be the image of God. "What we have to find in the soul of man, that is in the rational or intellectual soul, is an image of the Creator which is immortally engrained in the soul's immortality."227 Faith, knowledge of God's saving work in the incarnation, will not do. At the resurrection of the dead, faith and hope themselves will pass away, their traces remaining only as memories in those who will then be face to face with the Trinity itself.

\section{Image of God as activity}

The third and highest trinity of the inner human is the image of God. Its object of contemplation is God's eternal wisdom within, above, and immediately present to the rational soul. This final trinity of the mind's self-reflexive remembering, understanding, and loving of itself — within its remembering, understanding, and loving God—differs from the lesser trinities in important respects. Unlike the outer trinity of the body that consists of three distinct natures, the image of God exists in a single nature. Unlike the outer trinity of the mind that discovers outside itself that which it remembers, understands, and loves, the image of God is included within the object of its

\footnotetext{
${ }^{226}$ Trin. 14.2.5.

${ }^{227}$ Trin. 14.2.5.
} 
remembering, knowing, and loving. Unlike the two inner trinities of knowledge that pertain to things "adventitious to consciousness" 228 that either cease to exist or come to exist at the resurrection, the image of God is not adventitious but is an immortal trinity of the mind in the rational soul itself.

Unlike each of the lesser trinities that take place serially in time, the threefold procession that is the image of the Trinity in the mind constitutes an immortal simultaneity from the very moment that the rational soul comes into existence. Even faith and virtue, both essential to attaining eternal life, are not coterminous with the image of God in the mind. Faith "begins to be in the consciousness which was already a consciousness before faith began to be in it." ${ }^{, 29}$ And the cardinal virtues, which unlike faith will persist in eternity, also "begin to be in the consciousness, which was already there without them and was still consciousness." ${ }^{230}$ Only the mind is coterminous with the image of God in itself:

from the moment it began to be it never stopped remembering itself, never stopped understanding itself, never stopped loving itself ... when it turns to itself in thought, a trinity is formed in which a word too can be perceived. It is formed from the very act of thought, with the will joining the two together. It is here more than anywhere that we should recognize the image we are looking for. ${ }^{231}$

This threefold activity of the mind - in which a true word is generated from the mind's self-reflexive "minding" itself with a simultaneous and mutual affirmation of love proceeding from memory and word - is the object of investigation for a proper

${ }^{228}$ Trin. 14.8.11.

${ }^{229}$ Trin. 14.8.11.

${ }^{230}$ Trin. 14.9.12.

${ }^{231}$ Trin. 14.10.13. 
understanding of the image of God and, therefore, of the Trinity whose image it is. ${ }^{232}$

And yet, like any image, the rational soul cannot be said to be the image of God in and of itself, as if the creature could be this image without reference to the Creator it images. The rational soul is only the image of God in its relationship of active dependence upon God. More specifically, it depends upon God, as the object of its imaging, for its own enactment of its identity. "This trinity of the mind is not really the image of God because the mind remembers and understands and loves itself, but because it is also able [potest] to remember and understand and love him by whom it was made." ${ }^{233}$ Here we begin to see how the image of God differs not only from lesser trinities in important respects but also from the Triune God. Existing on opposite sides of the Creator-creature divide, the nature of the human mind, even the part that is the image of God, is not self-subsisting, a se, but derives its being from the being of God. When the mind's remembering, understanding, and loving of itself fails to simultaneously enact these dynamics with respect to God, this lacuna constitutes a failure to properly exhibit its creatureliness - it neglects to willingly acknowledge its nature as created, as essentially related to its Creator with respect to its derivation. Failing to acknowledge its origin, its maker, in this way, the mind exhibits folly rather than wisdom. The nature of the human rational soul is greater than all other created natures but is created nonetheless. A threefold self-remembering, self-knowing, and self-loving that lacks knowledge of the essential creatureliness of its own nature, the substance of its being, constitutes a mis-

\footnotetext{
${ }^{232}$ On the image of the Trinity as the human mind's activity, see Rowan Williams, "Sapientia and the Trinity: Reflections on the De Trinitate," in Collectanea Augustiniana: Mélanges T. J. Bavel, eds. B. Bruning, et al. (Leuven: Leuven University Press, 1990), I:317-32.

${ }^{233}$ Trin. 14.12.15.
} 
remembering, a mis-knowing, a mis-loving — a simultaneous, threefold failure in the order of being, knowing, and loving. Created with the capacity for remembering, knowing, and loving God, the refusal to actualize this capacity in one's true nature is both an offense to the Creator and an act of self-sabotage, self-destruction. The image of God is not reducible to the mind's activity of remembering, understanding, and loving itself considered independently and apart from its simultaneous remembering, understanding, and loving God. The latter activity is essential to the former.

\section{Image of God as capacity}

In addition to the sense in which the rational soul is the image of God in its active contemplation of wisdom, in a more basic sense the mind can also be said to be the image of God even when it is not enacting this capacity. For Augustine, the image of the Trinity refers most fundamentally to a capacity to contemplate God that is inherent in the nature of the human mind:

if it is with reference to its capacity [potest] to use reason and understanding in order to understand and gaze upon God that it was made to the image of God, it follows from the moment this great and wonderful nature begins to be, this image is always there, whether it is so worn away as to be almost nothing, or faint and distorted, or clear and beautiful. ${ }^{234}$

The image distorted — as with a sickness that needs healing and renewal—remains the image insofar as the capacity remains, even when the grace needed to activate that capacity in a rightly ordered manner is not yet or no longer present or effective. ${ }^{235}$ Even

\footnotetext{
234 Trin. 14.4.6.

${ }^{235}$ The priority I give to the capacity rather than its activity as the primary referent of image of God-because as Augustine points out this capacity persists even when the capacity is not actualized in relation to its proper object - puts me in the uncomfortable position of disagreeing with the interpretation of Williams. He argues that the image of
} 
though the enspirited mind never perfectly loves God, never perfectly contemplates wisdom, in this life the mind's nature never loses the capacity to do so imperfectly. The more the mind contemplates God and itself in God, the more its nature is healed, the better it knows itself, and the more properly it loves itself.

Precisely as a capacity that is not lost, the image of God persists across all four stages of human existence (i.e., no longer only in the last two as in the earlier writings). When the mind is not perfectly loving God, as is always the case in this life, it nevertheless retains in its nature the capacity to do so even when this capacity is veiled to itself and to others. That is not to say that the mind is capable of activating this capacity on its own. Being made capable of activating its capacity to love God requires regeneration of the inner human by divine grace. If God's mercy frees the will from the bondage of sin and God's grace gifts the human with God's own love in the Holy Spirit, then the mind's capacity to love God can be enacted. Only then does the image of God qua capacity actively manifest itself as contemplating wisdom. Where this takes place in this life, the image of God not only exists but is also undergoing a progressive renewal toward its eventual perfection in the eschaton: "when the mind loves God ... sharing in him results not merely in its being that image, but in its being made new and fresh and happy after being old and worn and miserable. ${ }^{, 236}$ In its fall from perfect integrity in the Garden to a state of corruption and concupiscence before the grace of regeneration, human nature was punished both with a weakened will incapable of controlling its appetites for lesser goods and with a darkened and confused intellect incapable of

God is "realized" in an activity of relating over against identifying the image with its latent potential in the nature of the rational soul (See "Sapientia and the Trinity," 321). ${ }^{236}$ Trin. 14.14.18. 
accurately perceiving the natural created order according to which its desires ought to be rightly ordered. In the eschatological state of glory, the mind will cleave to God whose image it is unchangeably, without any possibility of sinning. In that state of perfection, the image of God will love God perfectly. This will take place "with the mind attaining a share of his [God's] nature, truth, and happiness, not with him growing in his own nature, truth, and happiness" as happens when the mind contemplates God in the temporal state of grace in which regenerate humans live. ${ }^{237}$

Augustine never denies that the image of God could exist before the law or under the law. As we have seen, he affirms that Adam bears the image of God both before and under the law (before he disobeys God's command). It is only those of us, born with our inherited sin nature, who come into this life already having "lost" the image of God, according to the earlier writings. For us, before the law and under the law are always already a state of corruption. In De Trinitate the image of God persists in the human mind even after the Fall and before regeneration as was surmised initially in De spiritu et littera. That is, the mind is the image of God by nature, participating in God in the order of being, even when the mind is not participating in God in the order of knowingactively remembering, knowing, and loving God:

The mind must be considered in itself, and God's image discovered in it before it participates in God [particeps dei] ... even when it has lost its participation in God [amissa dei participatione] it still remains the image of God, even though worn out and deformed. It is his image insofar as it is capable [capax est] of him and can participate [particeps potest] in him; indeed it cannot achieve so great a good except by being his image. ${ }^{238}$

Because the image of God in the human mind refers first and primarily not to one's actual

\footnotetext{
${ }^{237}$ Trin. 14.14.20.

${ }^{238}$ Trin. 14.8.11. Augustine also compares the image of God as an existing capacity [capax est] with its potential participation [particeps potest] in Trin. 14.4.6 and 14.12.15.
} 
contemplation of God but to the capacity itself which remains even among those who are neither called nor elect, one often observes the capacity's use for other lesser goods. "It is in virtue of this light that even the godless can think about eternity, and rightly praise and blame many elements in the behavior of men." ${ }^{239}$ The moral capacity for judgment remains even in those for whom it has been corrupted and distorted by sin and whose loves are disordered. In this state of corruption, the Law of God evident in the natural order instructs pagan sinners, the unregenerate, to seek the aid of the Creator.

The man who does not do justice and yet sees what should be done, he is the one who turns away from that light, and yet is still touched by it. But the man who does not even see how one ought to live has more excuse for his sin, because not knowing the law he is not a transgressor; yet from time to time even he is touched by the brilliance of truth everywhere present, when he receives a warning reminder and confesses. ${ }^{240}$

The image of God persists in the state of corruption, surely not as the knowledge of faith and the contemplation of wisdom, but as a latent capacity for faith and wisdom as well as a moral capacity still capable, to some degree, of discerning and judging good and evil.

In both the state of corruption and the state of grace, the mind is mutable - "when it sees itself it does not see anything unchangeable." ${ }^{241}$ In both states, it is unhappy because it does not yet have what it by nature longs for, it does not yet look upon the face of God. ${ }^{242}$ Although in the present the human hopes for the happiness of the future beatific vision that it lacks here and now, the human does receive something new in being reborn, in becoming regenerate. The image of God qua capacity is not lost, and so it cannot be the image of God qua capacity that is received. What the human receives in being reborn, in the regeneration of conversion, is a justice or righteousness that is not its

${ }^{239}$ Trin. 14.15.21.

${ }^{240}$ Trin. 14.15.21.

${ }^{241}$ Trin. 14.15.21.

${ }^{242}$ See Ps 27.4, 1 Cor 13.12, 1 Jn 3.2. 
own but is merited by Jesus Christ.

And what will make it happy but its own merit and its Lord's reward? But even its merit is the grace of him whose reward will be its happiness. It cannot give itself the justice which it lost [perditam] and no longer has. It received it when man was created and lost it of course by sinning. So it also receives the justice by which it can merit happiness. ${ }^{243}$

Having been gifted with this righteousness, including the forgiveness of sins, the human can merit happiness by the holiness of a life that is lived thereafter in love of God.

Interpreting the image of God in eight biblical texts

An unprecedented occurrence in all of Augustine's writings takes place at this point in De Trinitate. To this point in Book 14, Augustine has argued all of the above regarding the image of God without quoting a single biblical text that refers to the image of God. A brief closing discussion in Book 14.16.22-19.25 provides a strong contrast and reverses that trend. Augustine quotes eight of the nine texts most important to his previous expositions of the image of God without explaining or even acknowledging the sudden turn to these biblical sources in such a concentrated manner-a unique confluence not only in this book and in De Trinitate, but in Augustine's corpus as a whole. In these few pages Augustine locates the claims and metaphors from each biblical text within his account of the progression of the image of the Trinity in this life and the image of the Son in the next. The four-stage progression that he details follows contours that are by now familiar to us, but here he employs a slightly altered vocabulary. In this small section where he addresses all of these biblical texts in conversation with one another, his treatment is framed in the categories of formation, deformation, reformation (a process of renovation undergone by the regenerate), and conformation (a state of resurrected

${ }^{243}$ Trin. 14.15.21. 
perfection to which Rom 8.29 refers). As before, the transitions between these stages are marked by the Fall, conversion, and the resurrection.

Having deformed itself by its inordinate desires for worldly [saeculares] things, the image of God became conformed to the world [saeculo], lost the ability to reform itself, and now finds itself in need of divine grace for its renewal and eventual conformation to the perfect image of the Son (i.e., the immortal spiritual body) for which it is predestined.

By being reminded [commemorati] they are converted to [convertuntur] the Lord from the deformity [deformitate] which had conformed [conformabantur] them by the worldly lusts to this world and are reformed [reformantur] by the Lord; they listen to the apostle, saying, Do not conform [conformari] to this world, but be reformed [reformamini] in the newness of your minds (Eph 4.24). And thus the image begins to be reformed [reformari] by him who formed [formata] it in the first place. It cannot reform [reformare] itself in the way it was able to deform [deformare] itself. As he says elsewhere, Be renewed [renovamini] in the spirit of your minds and put on the new man who was created according to God in justice and the holiness of truth (Col 3.10). "Created according to God" means the same as "to the image of God" in another text. But by sinning man lost justice and the holiness of truth, and thus the image became deformed [deformis] and discolored; he gets those qualities back again when he is reformed [reformatur] and renovated [renovatur]. ${ }^{244}$

Those who are reminded by God of God's intimate presence to them, and who respond to God's call by willingly turning toward God, begin a process of reformation in justice and holiness.

Augustine's philosophical and theological commitments - to a substance ontology, to the corollary conception of evil as a deficiency or a lack in one's nature, and thus to a Fall in which something of human nature is lost - require that he articulate a new account of what is lost in the Fall if it is not the image of God. Augustine replaces the image of God with the attributes of "justice and holiness of truth" [iustitia et

${ }^{244}$ Trin. 14.16.22. 
sanctitate veritatis] (Eph 4.24) as that which was lost in the original sin of human beings. The replacement concepts derive from the old human / new human texts that have been central to Augustine's framing of the image of God (in terms of virtue) from the very beginning — namely, Col 3.9-10 and Eph 4.23-24. First, he quotes the Ephesians text—Be renewed in the spirit of your minds, and put on the new man who was created according to God in justice and the holiness of truth. ${ }^{245}$ Identifying that which is lost in the Fall, Augustine equates the "in justice and holiness of truth" (Eph 4.24) with the "in the recognition of God" (Col 3.10)_- "in other words: Stripping yourselves, he says, of the old man with his actions, put on the new man who is being renewed in the recognition of God according to the image of him who created him" (Col 3.9-10). ${ }^{246}$ It is not the image of God qua capacity that is lost, but, rather, its proper functioning with justice or righteousness and holiness. As a result of the Fall, the mind's activity no longer recognizes itself in its relation to its Creator as its proper subject matter. Lacking justice or righteousness in the ordering of its desires, the life of the deformed human fails to exhibit the holiness or sanctity of life for which it was formed.

In the other place we read Put on the new man who was created according to God (Eph 4.24), and it is the same as what we have here, Put on the new man who is being renewed according to the image of him who created him (Col 3.10) ... this renewal takes place in the thing in which the image of God is to be found, that is in the mind. ${ }^{247}$

Reading Col 3 and Eph 4 together, Augustine identifies not only what was lost in the Fall — in what respect the deformed human lost its original form — but also identifies the rational soul and the image of God therein as the site of reformation.

The transition from the deformed image of God to its complete restoration is not

\footnotetext{
${ }^{245}$ Trin. 14.16.22.

246 Trin. 14.16.22.

${ }^{247}$ Trin. 14.16.22.
} 
instantaneous, and yet the inauguration of the reformation process is marked by a single moment of conversion: "this renewal does not happen in one moment of conversion, as the baptismal renewal by the forgiveness of sins happens in a moment, so that not even one tiny sin remains unforgiven." 248 The forgiveness of sins marks the beginning of the renewal of the mind. It is a necessary condition of being reformed and renewed and is done by God on behalf of humanity in Christ's work of atonement, an event that constitutes part of the subject matter of faith. Having proclaimed this faith, the newly baptized convert now begins the process of renewing the image of the Trinity. "The first stage of the cure is to remove the cause of the debility, and this is done by pardoning all sins; the second stage is curing the debility itself, and this is done gradually by making steady progress in the renewal of this image." 249 The image of the God in the inner human is renewed "by daily advances" as one progresses in faith, hope, and love, contemplating the eternal truths of the immanent Trinity.

2 Corinthians 4.16 provides the metaphorical distinction between the inner human and the outer human that Augustine maps as a distinction between the mind and that which is held in common with the animals. "Even if our outer man is decaying, yet our inner man is being renewed day by day (2 Cor 4.16). It is being renewed, however, in the recognition of God (Col 3.10), that is in justice and holiness of truth (Eph 4.24), as the apostle puts it." ${ }^{250}$ In this process of being remade "in justice and holiness of truth," only the inner human, the mind, is renewed day by day, whereas the outer human continues to disintegrate as a continuing punishment for Adam's original sin. The old human and new

\footnotetext{
${ }^{248}$ Trin. 14.17.23.

${ }^{249}$ Trin. 14.17.23.

${ }^{250}$ Trin. 14.17.23.
} 
human of Col 3 and Eph 4 both operate within this inner human as it relates to the outer human. That is, the old human and the new human refer to how the mind relates to the outer human. Either the inner human is old: deformed, still turned away from the recognition of God, and so not regulating the passions and appetites of the outer human, and not experiencing renewal in faith, virtue, and contemplation of God; or the inner human is new: regenerate, regulating the outer human and turned toward God in love and worship, and thereby growing in virtue, being renewed in righteousness and holiness. ${ }^{251}$

In this short section Augustine also provides new interpretations of 2 Cor 3.18 and $1 \mathrm{Jn} 3.2$. He considers these more difficult texts that might refer variously to the moment of conversion in the inner human, to the process of renewal in the inner human, to the perfected inner human, to the moment of resurrection, or even to the perfected resurrected body. In seeking to identify where these biblical texts fit within his four-stage schema, he outlines his vision of the progression of the image of God:

The man who is being renewed in the recognition of God and in justice and holiness of truth by making progress day by day, is transferring his love from temporal things to eternal, from visible to intelligible, from carnal to spiritual things; ... When the last day of his life overtakes someone who has kept faith in the mediator, making steady progress of this sort, he will be received by the holy angels to be led into the presence of the God he has worshipped and to be perfected by God so to get his body back again at the end of the world, not for punishment but for glory. For only when it comes to the perfect vision of God will this image bear God's perfect likeness." 252

In Book 14, Augustine initially locates the transformation "from glory to glory" spoken of in 2 Cor 3.18 as pertaining to the new human in stage three, the inner human undergoing renewal-But we with face unveiled looking at the glory of the Lord in a mirror are being transformed into the same image from glory to glory as by the Spirit of

${ }^{251}$ See Trin. 14.12.15. "The worship of God is wisdom" (Job 28.28).

${ }^{252}$ Trin. 14.17.23. 
the Lord (2 Cor 3.18); this is happening day to day to those who are making good progress. ${ }^{, 253}$ In Book 15, however, Augustine will return to this text and offer two alternative interpretations of the transformation in question. The first takes the referent to be the transition of regeneration in the inner human from deformed (stage two) to reforming (stage three), and the second, less-preferred reading takes the transition to refer to the resurrection, the moment in which the inner human moves from reforming (stage three) to perfection (stage four). In all three cases, Augustine takes 2 Cor 3.18 to refer to the mind. ${ }^{254}$

Augustine reflects upon a different ambiguity with respect to 1 Jn 3.2-Beloved, we are now sons of God, but that which we shall be has not yet appeared. We know that when he appears we shall be like him, because we shall see him as he is. ${ }^{255}$ Augustine takes the opportunity this text affords to refute a potential objection with which he has struggled for decades and which is of some importance to his understanding of the image

${ }^{253}$ Trin. 14.18.24. Nos autem revelata facie gloriam domini speculantes in eandem imaginem transformamur de gloria in gloriam tamquam a domini spiritu.

${ }^{254}$ As we saw above, "from glory to glory" [de gloria in gloriam] (from the Greek $\dot{\alpha} \pi \dot{o}$

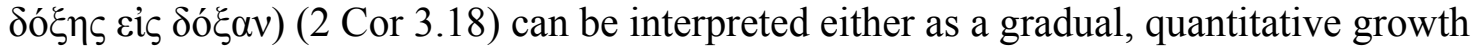
in the image of God in human persons on the soil of a virtue-like conception of sanctification as growth-in-godliness (thus the ESV, RSV, and NRSV: "from one degree of glory to another"; and, even more pronounced in the NIV: "with ever-increasing glory") or as a qualitative transition in glory. A translation that stays closer to the Greek and doesn't suggest an organic or gradual growth of the might read "to his image being transfigured, from glory to glory" without inserting "degree" or "ever increasing." Within Augustine's four stages, the more wooden translation can take Paul's "from glory to glory" to be a qualitative transition rather than a quantitative growth, referring to the differentiation of and transition between an initial glory of condemnation and a subsequent glory of justification referred to in 2 Cor 3.9-10. These two glories would not pertain to a remade image of God or a gradual renewal of God's image, but to a qualitative transition from unregenerate to regenerate. This is how Augustine reads the removal of the veil in 2 Cor 3.18, and in Trin. 15.8.14 it is his preferred interpretation for the "from glory to glory" as well.

${ }^{255}$ Trin. 14.17.23. 
of God as an image of the Trinity. He suggests that "we shall be like him" might indicate either the perfected image of God in the inner human, in the mind, or the image of God the Son, the immortal spiritual body. "It is clear that the image of God will achieve its full likeness of God when it attains to the full vision of God-though this text from the apostle John might also appear to be referring to the immortality of the body." ${ }^{256}$ This latter interpretation opens up a way of incorporating texts that might seem to refer the image of God to the Son rather than to the Trinity as a whole. Of course, that the image of God refers to the Son in a particular respect rather than to the Trinity as a whole is a position that Augustine himself had advanced in earlier writings. ${ }^{257}$ Four biblical texts that provide the strongest warrants for Augustine's earlier interpretations are Rom 8.29, 1 Cor 15.49, 2 Cor 4.4, and Col 1.15. The latter two texts state that Jesus Christ is the image of God. ${ }^{258}$ Although Augustine makes extensive use of other biblical texts

\footnotetext{
${ }^{256}$ Trin. 14.18.24.

${ }^{257}$ See, for example, the above discussions of Gn. adv. Man., Gn. litt. inp., Gn. litt., and div. qu.

${ }^{258}$ Augustine never identifies the incarnate Christ-God, soul, and flesh [deo anima et carne] (Trin. 13.17.22) - as the image of God, but only the eternal Son of God whose nature is a simple consubstantial unity with the Father's nature. The reason, at least in part, has to do with the fact that the biblical texts that later theologians would appeal to insupport of support claims - clauses that identify Jesus Christ as the imago dei in 2 Cor 4.4 and $\mathrm{Col} 1.15$ - are ones that Augustine never engages in a sustained exposition, never exegetes, and does not cite (with the exception of a single, quite late citation of 2 Cor 4.4 where the exposition focuses on another clause- the God of this world has blinded the minds of unbelievers [see c. adv. leg. 2.7.29]).

Augustine seems unaware of the explicit identification of the image of God with the incarnate Christ in the introductory phrase of $\mathrm{Col} 1.15$, "He is the visible image of the invisible God." The subsequent phrase of Col 1.15- he is the firstborn of all creation, and he is before all, and all things hold together in him-is quoted in Trin. 1.12.24 where Augustine's citation suggests either that the Vetus Latina text with which he is working lacks the reference to the image of God or that he inexplicably begins his quotation directly after the imago dei reference.

The introductory clause to Col 1.15 does appear three times in Augustine's corpus: in conl. Max. 718 (c. 427), div. qu. 74 (c. 390), and retr. 2 (c. 428). In the first, it is not
} 
Augustine but Maximus who quotes the verse in a debate with Augustine. Augustine does not respond to this citation and may or may not have recognized it as deriving from scripture. The second and third instances, also record a question put to Augustine by an interlocutor. Again, Augustine's response does not address anything that is particular to this biblical text, the incarnate Christ, or the second person of the Trinity, but instead deals with various types of "images."

That Augustine's quotations of Col 1.15 elsewhere also lack the relevant introductory clause (See, for example, c. Sec., qu., conl. Max. 730, 734, c. s. Arrian.) suggests the possibility that its use in div. qu. 74 may have been a redaction initiated by a different translation, perhaps the Vulgate, used in Conlatio cum Maximino at the same time that Augustine was working through his Retractiones.

Retractiones explains that De diversis quaestionibus octoginta tribus was a random order of questions by the fratres that he had answered and which he ordered to be collected into a single book for those who might have similar questions. This explains the less than linear sequence of questions that don't come together in an orderly argument. It was not Augustine who pulled together these materials, but those whom he had ordered to do so. Given that these were questions asked by others and that Augustine delegated the task of collecting his dictated responses to these random questions, it is conceivable that Augustine himself never gave a close reading to the book in its final form until his Retractiones (if then). It is possible that while reading through this old collected work Augustine came across the introductory clause of Col 1.15. It was precisely at this time (427) that Maximinus would twice quote it in his debate with Augustine (see conl. Max. 13, 15.14). Because Maximinus took so long in his last speech of the debate, Augustine penned a long point-by-point response to Maximinus that fails to quote Col 1.15, but does respond to Maximinus's quote of Col 1.16 (see c. Max 1.2.2).

The response to div. qu. 74 does not address the verse or any of its particularities-i.e., creation, accomplishment of redemption, the remission of sins, or the attribute of invisibility, but only the concept of "image." Instead, this response is a philosophical treatment of the distinctions between image, likeness, and equality (though the latter two attributes are not mentioned in this verse). The conclusion asserts that the Son is the image, likeness, and equal of God. Given that this is one of two biblical texts in which the phrase imago dei occurs, it seems odd that Augustine knew of this verse in $390 \mathrm{CE}$ and never again refers to it in the subsequent 40 years. Furthermore, in this one place that quotes the verse, it is only in the questio and the phrase "imago dei" does not appear anywhere in the philosophical examination of the relationship between image, likeness, and equality.

Also odd is the fact that Augustine in this discussion of image clearly has in mind the eternal Son and does not consider the humanity of Christ as Col 1 (and even more so 2 Cor 4.4) does. That Augustine elsewhere quotes the phrase immediately following the imago dei, but never again the imago dei portion of the text, only adds to the enigma of why this verse, among all the verses pertaining to the imago dei, is never exegeted by Augustine. As noted above, in the one question where the verse Col 1.15 is quoted, Augustine never discusses the one phrase from this verse that is relevant to the discussion - namely, imago dei - and instead dwells on the relationship of imago, 
referring to the image of God, he does not discuss the latter two identifications of Jesus Christ with the image of God. We have seen that the former two texts are important to Augustine's early conception of the image of God - the image and likeness of God, in and through whom human beings are created, is the Son of God to whom Christians are also remade and progressively renovated in this life. While Ambrose and Origen certainly influenced Augustine's early identification of the Son with the image of God, Augustine repeatedly cites Rom 8.29 and 1 Cor 15.49 (and not 2 Cor 4.4 and Col 1.15) as the two biblical warrants that point in this direction. ${ }^{259}$ In the earlier writings, other biblical texts and metaphors are read through the lens or constraints these texts provide. In $D e$ Trinitate, as in Confessiones, Augustine appeals to the "Let us make man to our image and likeness" of Gen 1.26-27 as the reason for identifying the image of God in the inner human as the image of the Trinity. ${ }^{260}$ The ambiguity to which $1 \mathrm{Jn} 3.2$ points is the distinction between these two dimensions of the image of God after Confessiones.

After 397 Augustine gradually re-imagines his earlier framework with the help of additional biblical texts and metaphors. The distinctions of inner human / outer human (2

similitudo, and aequalitas to one another. (See R.A. Markus, “'Imago' and 'similitudo' in Augustine," Revue des études augustiniennes [1963]: 125-143).

I am inclined to believe that Augustine himself never actually quoted Col 1.15. In what can only be a speculation, it seems possible that either he had a text of Colossians that lacked the "imago dei" phrase and so was suspicious (perhaps for theological reasons as well) of its inclusion in other versions of the text, or he simply did not have any texts that read "imago dei" in Col 1.15. The one place that Augustine cites 2 Cor 4.4, he does not offer any exposition of the imago dei (c. adv. leg. 2.7.29). Where 2 Cor 4.4 is cited elsewhere in Augustine's corpus, Felix quotes it in a debate. Again, Augustine does not address the verse in his response (See c. Fel. 2.2).

${ }^{259}$ Trin. 14.18.24 is the only passage in De Trinitate where Augustine cites these texts (Rom 8.29 and 1 Cor 15.49) that are much more prominent in his earlier writings on the image of God. As we will see below, in Section I.8, these texts are more significant for Augustine's purpose of distinguishing the two cities in other writings from this period. ${ }^{260}$ Trin. 14.19.25; conf. 13.22.32. 
Cor 4), old human / new human (Col 3 and Eph 4), and earthly human / heavenly human (1 Cor 15) had all previously indexed the same phenomenon-namely, a gradual renewal to the image of God in the rational soul of those already made to God's image in regeneration. We have already seen that in De Trinitate Augustine distinguishes among five trinities of the inner human and outer human, re-appropriating the metaphor of inner and outer to refer to capacities humans do not share with the beasts and those that they do share, respectively. The inner human refers to the mind (enspirited or not), and the outer human refers to the body (enspirited or ensouled). And, we have seen that in stage three Augustine continues to operate with the metaphor of the old human and the new human to describe a gradual progress in which the nature of the rational soul is healed in this life through virtuous works that require faith. This leaves the earthly human / heavenly human metaphor of 1 Cor 15 . Having interpreted "the image of the one who is from heaven" (1 Cor 15.49) as the enspirited resurrected body in De Genesi ad litteram, Augustine now adds that it is this immortal spiritual body to which Paul refers as "the image of his Son" in Rom 8.29.

For Augustine, the image of God in the resurrection has two referents. The image of the Trinity is the mind's capacity for divine wisdom. The image of the Son is the immortal spiritual body. The former occurs progressively in stage three and is perfected in stage four. The latter takes place instantaneously at the resurrection of the dead, "in the twinkling of an eye" that marks the transition from stage three to stage four and persists in that perfection.

1 John 3.2 clearly falls within stage four, the state of perfection, but to which image does the statement "we shall be like him because we shall see him as he is" refer? 
Does the resurrected Christian see the Son or the Trinity? Augustine observes that $1 \mathrm{Jn}$ 3.2 also states that "we are sons of God," and he takes "God" to be the antecedent of "him" and therefore as a reference to the Trinity rather than to the Son in particular. Thus, in De Trinitate, $1 \mathrm{Jn} 3.2$ no longer refers to the vision of the Son as it had in Expositio quarundam propositionem ex epistula apostoli ad Romanos and De Genesi ad litteram. Instead, in the state of perfection it is the Trinity that the resurrected human will contemplate and see face to face. Whereas Rom 8.29 and 1 Cor 15.49 refer to the eschatological image of the Son, 1 Jn 3.2 refers to the eschatological image of the Trinity. Augustine will put these texts from Rom 8 and 1 Cor 15 to additional use in later writings where a division of humanity into two citizenships takes greater prominence. As we will see, this distinction is as important to his interpretation of these biblical texts pertaining to the image of God as it will be to his ethics. 
I.7 Distinguishing Citizenships: Election and the image of the Son (420-430)

The two cities metaphor was not novel when Augustine employed it in De civitate Dei (413-426). It had been utilized by Augustine in sermons, catechisms, and letters dating twenty years prior to his magnum opus. ${ }^{261}$ Although not new, the civitas dei metaphor does occupy substantially greater portions of Augustine's writing after 413, and it increasingly provides the organizing framework of Augustine's thought, giving the impression of a basic structural feature of Augustine's theological and moral imaginary. ${ }^{262}$ It becomes the dominant distinction in Augustine's anti-Pelagian writings by means of which persons are distinguished — one's citizenship is either in the city of God or its alternative, the terrena civitas. The elect are the citizens of the city of God and the reprobate are citizens of the earthly city.

Prior to writing De spiritu et littera in 413, before work on De civitate Dei began, Augustine had considered the image of God a useful means of distinguishing the elect from the reprobate - the regenerate were the elect who had been remade in the image of God and the unregenerate were those who lost the image of God in the Fall and had not, or (if elect) not yet, been remade. Subsequent to De spiritu et littera, the earthly city/heavenly city distinction replaces this construal of the lost/remade image of God as the primary means of distinguishing the elect from the reprobate. The reason, as we have seen, is that subsequent to 413 the image of God names a feature of the human that is not

${ }^{261}$ See en. Ps. 9.12, vera rel. 27.50, cat. rud. 31, 37, Gn. litt. 11.15.20; 12.28.56. See also Chapter 4, "The Theme of Two Cities," in O'Daly, Augustine's City of God.

262 The second half of De civitate Dei (Books 11-22) charts the two cities' histories, and the composition of Books 11-14 (416-420) coincides with the crescendo of attention to the scriptural sources informing the image of God in De Trinitate that we have been observing. Augustine's climactic exposition of the scriptural sources of the image of God in Trin. 14.16.22-19.25 follows shortly after composing civ. 14. 
lost in the Fall but is coterminous with the rational soul itself, it is not conceived as adventitious to the rational soul. As a result of this revised conceptualization, two scriptural texts that had long been integral to Augustine's understanding of a restoration of a previously-lost image of God become central to his differentiation between the elect and the reprobate.

Those on whom God in His just and inscrutable predestining will sees fit not to include in his mercy belong to the terrena civitas, the earthly city ordained for eternal damnation. And, whereas the city of God is united by its common love and enjoyment of God, that which unites and binds the terrena civitas is a common lie.

De Trinitate is the final text in which Augustine gives the image of God significant and sustained attention. Outside of De Trinitate, after 420 the only two scriptural texts that Augustine had previously relied upon in developing his understanding of the image of God which continue to be taken up with any frequency are Rom 8.29 and 1 Cor 15.49. As noted earlier, unlike all of the other texts that had previously been important to Augustine's developing conceptualization of the image of God, these two texts are cited only once in De Trinitate. ${ }^{263}$ There, Augustine tells us that the reason they were not important for De Trinitate's discussion of the image of the Trinity in the rational soul is that he no longer considers the "image of the Son" and "the image of the heavenly man" as references to the image of God in the rational soul. Rather, these two metaphors that were once taken as references to the image of God now index, instead, the resurrected body that the elect will have in common with the resurrected Christ.

${ }^{263}$ See Trin. 14.18.24. 
Subsequent to Confessiones, Augustine works with a distinction between the image of the Son or the image of the heavenly human, on the one hand, and the image of the Trinity in the human mind, on the other. Certainly before 420, but increasingly afterwards, the images of the Son and of the heavenly human, in Rom 8.29 and 1 Cor 15.49, are repeatedly cited in reference to the distinction between the elect and non-elect, the citizens of the heavenly city and the earthly city, those predestined according God's merciful plan and purposes and those not so predestined. ${ }^{264}$

Especially in the second half of De civitate Dei, the two cities serve as a basic organizing frame for Augustine's theological imaginary, so to speak, and this commitment corresponds to his understanding of the imago Filii. All, by nature, possess the image of God, the image of the Trinity in the rational soul, but not all are predestined to be conformed to the image of the Son (Rom 8.29). Not all will bear the image of the heavenly human, the resurrected body (1 Cor 15.49). Not all are elect. And thus, not all shall see God (1 Jn 3.2). In short, not all are citizens of the City of God.

Augustine often cites Mt 22.14 where he develops this collection of claimsMany are called few are chosen. ${ }^{265}$ The few who are "chosen" in this sense are chosen according to God's merciful purposes. They are those "predestined to be conformed to the image of the Son" (Rom 8.29), those who will inherit an immortal body after the resurrection of the dead. For Augustine and much of the tradition after him, others are chosen for a different use and a different purpose — namely, manifesting the holiness of God in the divine judgment of sin. Judas is often paradigmatic of this latter, unenviable

${ }^{264}$ Augustine already associates these scriptural texts with predestination in ep. 186 . See the many citations after 420 in Appendix A.

${ }^{265}$ See, for example, civ. 13.23. 
sense of being “chosen." Such persons are chosen not to be true disciples, regardless of what external appearances might indicate, but, at least in part, to provide cautionary tales for God's elect. In the saeculum, the world between Christ's first and second comings, the elect and reprobate share whatever relative peace they can muster together in their Babylonian exile. The civitas dei and civitas terrena are intermixed in this shared saeculae civitas, the city of this age prior to the eschaton.

Augustine believes that the divine election that differentiates the elect from the reprobate is inscrutable. God's eternal electing will is not only inscrutable with respect to God's reasons for electing one particular person and not another, God's election is also inaccessible in the sense that one cannot know with certainty the predestined status of any particular person-i.e., whether the person is determined as elect or reprobate-including oneself. Thus, among the members of the visible church are those presently regenerate and unregenerate, each of whom is also either eternally elect or reprobate. The Christians among one's neighbors include faithful Catholics pursuing the mortification of the flesh and the renewal of the inner human, but also heretical and schismatic Christians who may or may not be regenerate. Of those who are not regenerate, a portion is nonetheless elect.

Augustine does not imagine that human beings can effect the conversion of another human being apart from the divine grace of the Holy Spirit working in that person. As a student of the scriptures, however, he perceives God working through human beings, natural phenomena, and even physical force as efficient causes in bringing about the conversions for which disciples such as Philip, Peter, and Paul were eternally predestined. His Confessiones detail his own experience of God's paternal love working through both his fears and his good desires. 
If scripture and experience demonstrate that God makes use of coercive means for the benefit of his elect — whether covenant promises about punishment and reward, miraculous wonders, or suffering affliction — then surely God's children, the peregrine citizens of the heavenly city, will allow themselves to be used analogously while also making just use of the persuasive and coercive means at their disposal to the extent that they are able, all to the glory of God and for the benefit of others-viz., the elect. So, although the use of coercion by Christians aims at others' conversion, it does not change the ultimate status of anyone with respect to God's predestination, even when such coercion becomes part of the therapeutic regimen utilized both by God and by the citizens of the city of God. As we will see, however, whereas coercion might be used by God and God's children as an efficient cause in the conversion of those who are eternally elect but temporally not yet regenerate, according to Augustine lying is absolutely excluded as a means or tool in the otherwise quite liberal practices of coercion.

In order to understand why this is the case, we pick up where we left off with our discussion of the image of God, with De Trinitate 15. Here, after his most extensive exposition of the image of God and the scriptures that guide his judgments, Augustine introduces the ethical question of lying. 
I.8 Seven Developments in Augustine's imago dei (396-430)

We have observed Augustine's understanding of the image of God developing considerably. Understanding how and why Augustine's thinking about the image of God develops requires attention to the ways in which his use of biblical sources for this concept change over time. Seven developments in his thinking can be traced to interpretations of specific scriptural texts that Augustine himself presents as warrants for his reasoning. Where Augustine's mind changes on a topic, he rarely makes this as explicit as in the retrospectives in Confessiones and Retractiones where he narrates some of these developments for us. More often, identifying where developments take place requires attending to his interpretation of biblical texts and his deployment of their metaphors before and after these expositions. Through such careful reading we are able not merely to observe interesting coincidences of biblical exegesis and theological innovations but also to follow how Augustine draws on the ideas and distinctions in these texts as he unfolds or constructs his understanding of the image of God.

Augustine's initial interpretations of the image of God owe much to the " $a d$ " of ad imaginem et similitudinem of Gen 1.26-27. They emphasize that human beings are created by, to, and through the image of God. Significantly, in these early texts, the image of God is understood to be the Son of God. This interpretation comports well both with New Testament texts that indicate Jesus Christ, the Son of God, is the image of God and with a virtue-framed conception of progressive renewal of God's image that proves a mainstay of Augustine's third of four stages of human existence. Here, the Son, qua image of God is consubstantial and coequal with the Father.

After two expositions of Gen 1, though still relatively early in his development, 
Augustine makes an important first revision that provides the activation energy, so to speak, that would allow more and other changes to follow. At the conclusion of his Confessiones (c. 400), he reconsiders the implications of Gen 1.26-27 where the human is said to be created "to our image" and "according to our likeness." This leads him to foreground the conviction that human beings are not created to the image of God-where the Son is understood as the perfect image and likeness of the Father-but, instead, to the image of the Trinity. What this will come to mean for Augustine is far from clear at this point.

Shortly after Confessiones, in a fateful move with enduring consequences, he exegetes 1 Cor 11.7. This is the one New Testament text which states that a human being $i$ s the image of God (without reference to the Son) and which also attributes the image of God to the male as opposed to the female human being. In De opere monachorum (401), where Augustine first cites 1 Cor 11.7 as a warrant for a second important revision- the claim that the human being is not only created in or to the image of God, but is the image of God-he does not quote the portion of the text that seems to exclude the female. Where he later quotes the exclusionary phrase, Augustine interprets this text allegorically or spiritually in order to harmonize it with his application of the image of God to both "male and female" as in his interpretation of Gen 1.26-27. That is, a literal reading of 1 Cor 11.7 enables him to argue that human beings other than Jesus Christ are the image of God, while a spiritual reading of the same text allows him to affirm that male and female equally bear the image of God, even as the text ascribes the image only to the male [vir]. Whereas previously he had interpreted Gen 1, Col 3, Eph 4, 1 Cor 15, Rom 8, and 2 Cor 4 within a reading that affirmed the Son is the image of God to which all human beings 
are created, after his exegesis of 1 Cor 11.7 , in 401 , he would consistently affirm that the individual human being is the image of God with respect to the rational part of the human soul.

Understanding the human to be the image of the Trinity leads Augustine to interpret "conformed to the image of his Son" (Rom 8.29) no longer as referring to the renewal of the mind but as referring to the resurrected spiritual body, a referent that comes to be shared with the "heavenly man" of 1 Cor 15.49 . These texts, along with $1 \mathrm{Jn}$ 3.2, had previously been considered synonymous with the old human / new human distinction of Col 3 and Eph 4. Reinterpretation of these texts constitutes Augustine's third revision. "The image of the Son" refers not to the enspirited mind's perfection (as it previously had) but to the enspirited body, the "heavenly man" of whom it is said, "we shall be like him for we will see him as he is." In a later, related revision, 1 Jn 3.2 would eventually come to refer not to seeing the spiritual body of the Son, but to the beatific vision of the Trinity itself.

In the case of Augustine's changed position regarding the loss of the image of God in the Fall, Augustine's own assessment of the matter in Retractiones corroborates a coincidence of contemporaneous texts in which Augustine reflects for the first time on 2 Cor 3.18 that apart from his testimony would have been merely circumstantial. In Retractiones Augustine cites this biblical text as a warrant for his changed position. This is Augustine's fourth and perhaps his most significant revision with respect to the image of God-namely, the image of God is not lost in the Fall. ${ }^{266}$

Interestingly, both in the writings of 412/413 in which Augustine overturns his

${ }^{266}$ See retr. $1.26(25)$. 
position on the Fall vis-à-vis the image of God and in the later discussions from $D e$ Trinitate 14 and 15, Augustine vacillates regarding whether the distinction in 2 Cor 3.18 - from glory to glory-refers 1) to the moment of conversion, 2) to the moment of transition to the resurrected life, or 3) to the process of renewal that takes place in the interim. Augustine is more confident that the veiling and unveiling of the image of God, to which this text refers, entails that it is not lost. And it is this conviction that leads him to identify the image of God with a capacity in the human nature for the contemplation of God - a fifth revision - that persists even in those for whom it is not empowered or activated by the divine grace and love of the Holy Spirit.

A sixth revision once again draws upon the spiritual reading of 1 Cor 11.7 in which the male and female are understood to signify two parts of the human. This revision is more of a series of revisions or a trajectory rather than one development. Initially, Augustine takes the male to signify the mind and the female to signify all that is concupiscent in the human person - the male is to have dominion over the female as the human is over the non-rational animal, as Christ is over the Church, and as the rational soul is over its irrational elements and the body. Augustine's second reading promotes the female from signifying all of the elements in human nature, including the material body, to signifying all of the non-rational elements except the physical body. Here, it is the serpent that takes over this signifying function previously assigned to the female. Augustine's final reading relocates the distinction of 1 Cor 11.7 so that both male and female signify the mind - the inner human of the inner / outer distinction of 2 Cor 4.16 but in such a way that only the male signifies the contemplation of wisdom whereas the female signifies the active knowledge that manages temporal things. Attendant to this 
change is a re-conceptualization of the relationship between the male and the female in the Fall from grace.

A seventh revision involves an implicit change in how one approaches interpersonal relationships with other-than-Catholic-believers. In earlier writings, Augustine takes the will to be free with respect to faith. God responds with grace to the freely chosen human faith that God foresees. In this way, God is recognizably just and the human's freedom to believe is affirmed. The grace with which God responds to human faith remakes the image of God in the believer and the enspirited mind is made capable of progressing in this faith by participation in the Catholic moral life. In this scheme, one's interactions with non-believers might include arguments attempting to convince others to embrace the Catholic faith in order to receive divine grace- - nonCatholics have the capacity to respond without the aid of divine grace. Once Augustine revises his understanding of the will's freedom with respect to faith, he is less optimistic about arguments that might persuade the non-believer. It is not up to the non-believer whether to choose faith, as God's inscrutable predestination of those who will believe and not believe does not respond to any merits that the human might bring, not even the merit of choosing faith. Engaging non-believing interlocutors regarding the faith, one's engagement with non-believers is for the benefit of those listening in, those believers who might overhear, be encouraged by, and strive all the more for their progress in loving God and the renewal of the image of God in their minds. Although the image of the Trinity in the human mind is a capacity that all human beings possess in Augustine's later writings, it is a capacity that none other than God in the power of the Holy Spirit is capable of activating. 
Ingredient in all of the developments above is a sort of unfolding that takes place in Augustine's interpretation of the image of God. The unfolding starts from a vision of the image of God in which all of the texts initially considered were viewed within the framework of virtue as indexing a gradual growth toward perfection in this life by those within the Church - by choosing faith, through participation in the Catholic moral life. Gradually, as Augustine attends to the particularities of the various texts' distinctions between old and new, inner and outer, earthly and heavenly, all begin to unfold outward, mapping onto a broader array of phenomena. As the texts unfold they disclose not one image of God but two, one of the Trinity and one of the Son- one of the mind and one of the spiritual body. The image of the Trinity is in the inner human as opposed to the outer human, a capacity present across four stages rather than a gradual and then perfect freedom from concupiscence only in the last of several steps. The biblical texts more clearly indicate two instantaneous transformations in the life of the elect in addition to the one gradual development to which they initially referred. Five trinities of the mind offer more possibilities for spiritual readings than the earlier, simpler mind-body duality options.

Once we are aware of these developments, it is difficult to affirm Bonner's generalization that "it is reasonable to regard his opinions on most theological issues as having been established by the time he became sole bishop of Hippo in 396, though controversy with the Pelagians constrained him to clarify his understanding of the effect of sin on the image of God in the human soul. ${ }^{, 267}$ Bonner notes of Augustine's claim that

\footnotetext{
${ }^{267}$ Gerald Bonner, “Augustine's Doctrine of Man: Image of God and Sinner," Augustinianum 24 (1984): 495-514, 497. Bonner acknowledges the "notorious exception" of Augustine's altered attitude toward the coercion of the Donatists. Bonner estimates
} 
"by sin Adam lost this image" in De Genesi ad litteram is an "expression which he later modified," and he finds it "reasonable to assume that this change of opinion was due rather to Augustine's own thinking than to any controversial necessity" brought about by the challenge of Pelagianism. Bonner considers the later position far more consonant with the major contours of Augustine's theology and thus focuses on what possible reasons might account for Augustine's early position. ${ }^{268}$ The explanatory power derived from careful attention to the controversies in which Augustine was engaged has been essential to Augustine scholarship. However, when these controversies do not seem catalysts for particular claims or developments, attributing changes in opinion to the catch-all of "Augustine's own thinking," as Bonner does in this instance, runs the risk of tautology, telling us nothing about how or why Augustine's mind changed on the matter under consideration.

Each of the seven developments listed above can be traced to Augustine's engagement with specific biblical texts that invoke the image of God and with which he concludes his exposition of the image of God in De Trinitate 14. All seven developments occur after Augustine became bishop. If it is true in other respects, as Bonner suggests,

this change in Augustine's thinking, once advanced but later qualified considerably by Peter Brown, a late, significant development or alteration rather than a clarification. ${ }^{268}$ He notes three: According to the Enneads of Plotinus an image attains a true likeness of its original by facing it, being turned toward it in contemplation. Thus, when human beings turn away from God and love other things after the Fall and before repentance, they are turned away from God and are not the image of God. Second, Augustine accords creation in the image of God to the rational soul, that part of the human that differentiates it from the beasts and makes the human capable of eternal life. Between the time when eternal life is forfeited and when it is again received, the rational soul does not participate in eternal life and may forfeit the image of God as well. Third, the two-fold creation in Adam and new creation in Christ (2 Cor 5.17, Gal 6.15) - where creation is by definition ex nihilo and the image of God in the human is that which is re-created-implies that the image of God does not exist prior to God's creative activity. 
that "it is reasonable to regard his opinions on most theological issues as having been established by the time he became sole bishop of Hippo in 396," then the image of God must be considered an exception. Augustine's theological genius is difficult to measure, and his development with respect to the image of God over his writing career is impressive as he considers alternative interpretations and develops various scriptural metaphors and motifs for his own purposes. One hesitates to speculate as to the trajectories his understanding of the image of God might have taken and how this concept might have continued to develop had he been given the opportunity to incorporate more fully those texts that he was only beginning to incorporate quite late in his life. In Part II we will consider how the conception of the image of God at which Augustine actually arrived in his mature writings shapes the ways that he thinks about ethics. 
II.1 Introduction: The Problem of Augustine's Ethics

Augustine's staunchest critics and most sympathetic readers alike find his ethics vexing. Lying and coercion are two of the more perplexing ethical topics to which Augustine scholars and Christian ethicists regularly turn, and proposals for rehabilitating or reconciling his seemingly incommensurable judgments are standard fare among scholars engaging his ethics of lying and coercion. ${ }^{1}$

For example, regarding coercion, John Bowlin observes that "many of his critics suspect that he does not believe his own 'threadbare arguments,' or at the very least should not, given that his efforts to justify coercion are inconsistent with his more settled views about virtue, freedom, and the limits of political authority in the saeculum.", If "we cannot imagine sharing Augustine's conclusions about the use of coercion against religious dissent," then perhaps we have misunderstood what Augustine is up to. ${ }^{3}$ In an effort to make Augustine more comprehensible, Bowlin directs attention away from the conclusions that are alien to readers and highlights instead those features of his context and, more importantly, his moral reasoning with which readers more readily identify. If we cannot imagine consenting to his judgments about political and religious coercion,

${ }^{1}$ See, for example, Alan Brinton, "St. Augustine and the Problem of Deception in Religious Persuasion," Religious Studies 19 (1983): 437-50; Robert Dodaro, "Eloquent Lies, Just Wars and the Politics of Persuasion: Reading Augustine's City of God in a 'Postmodern' World," Augustinian Studies 25 (1994): 77-137; Alain Epp Weaver, "Unjust Lies, Just Wars? A Christian Pacifist Conversation with Augustine," Journal of Religious Ethics 29:1 (2001): 51-78; James Turner Johnson, "Can a Pacifist Have a Conversation with Augustine?: A Response to Alain Epp Weaver," Journal of Religious Ethics 29:1 (2001): 87-93; David Decosimo, "Just Lies: Finding Augustine's Ethics of Public Lying in His Treatments of Lying and Killing," Journal of Religious Ethics 38:4 (2010): 661-697.

${ }^{2}$ Bowlin, "Augustine on Justifying Coercion," Annual of the Society of Christian Ethics (1997): 54.

${ }^{3}$ Bowlin, "Augustine on Justifying Coercion," 54. 
perhaps we are nevertheless quite close to him with respect to forms of moral reasoning, basic dispositions, and aspirations. The advantage of such an approach is that it familiarizes Augustine. It makes us see how much nearer we are to him, and he to us, in spite of his explicit judgments that might lead us to believe otherwise. According to Bowlin, by virtue of a common human nature, we share with Augustine a collection of reason-giving practices, capacities for moral discernment, and common moral intuitions that make our judgments for the most part intelligible to one another.

Paul Griffiths' strategy for reading Augustine's ethics of lying is nearly the opposite. His aim is not to show Augustine's ethics are commensurable with our shared practices or natural intuitions, but rather to disclose just how alien are Augustine's doctrinal commitments, moral grammar, and formative practices to those taken for granted within a consumerist and individualistic "late-capitalist democracy." 4 According to Griffiths,

You, as reader of this book, are almost certain to have moral and practical intuitions that make the Augustinian ban on the lie unacceptable and the reasons for the ban dubious. This will be true whether or not you are a Christian: the distance between Augustine's metaphysic and ours is great; greater still would be the distance between a community that took the Augustinian ban seriously - a community of truth - and the forms of social, political, and economic life in which we live and move and have our being. 5

Griffiths' goal is not to show the reader how Augustine's moral reasoning is like ours, but to introduce the reader to Augustine's moral reasoning in a way that defamiliarizes for the reader his or her own context, thereby enabling their taken-for-granted assumptions to

\footnotetext{
${ }^{4}$ Paul J. Griffiths, Lying: An Augustinian Theology of Duplicity (Grand Rapids, Mich.: Brazos Press, 2004), 229.

${ }^{5}$ Griffiths, Lying, 226.
} 
come into view. He aims to explain to the reader why he or she will remain inclined to disagree with Augustine, even though Augustine is correct: "For those who are not Christians already, such persuasion would require assent to a large number of truths about God's nature and the image of God in us, for Augustine thinks that what he argues about the lie presupposes the truth of such Christian convictions."

Although Bowlin is writing about coercion and Griffiths about lying, they share the common experience of finding Augustine initially perplexing and a common goal of making his ethics intelligible (if not agreeable) to a modern readers. Both scholars find interpreting Augustine's ethics less than straightforward and so seek to explain them in light of his particular social and cultural context and philosophical and theological commitments, all of which are alien to many readers today.

In offering their explanations, however, Bowlin and Griffiths devise different, and in important ways opposed, reading strategies. They and other scholars arrive at disparate accounts of Augustine's ethics, at least in part, because their interpretations tend either to civilize Augustine according to contemporary moral norms or to make him alien to modern sensibilities. Are Augustine's ethics largely our own or do they instead represent a quite distinct tradition of moral enquiry? Are his moral intuitions, upon closer examination, largely our own as Bowlin suggests? Or, is Griffiths nearer to the truth in defending Augustine's moral reasoning about lying precisely on the grounds of a particular Augustinian doctrine of the Trinity and of the image of God?

Developments in recent historical literature only add to the reasons for consternation with the predictable consequence that proposals for resolving alleged

\footnotetext{
${ }^{6}$ Griffiths, Lying, 15 .
} 
tensions or reconciling apparent inconsistencies multiply. ${ }^{7}$ Take, for example, Peter Brown's and Robert Markus's recent appraisals of their earlier writings. Some forty years since Brown's epic biography and Markus's Saeculum first appeared, both scholars have revisited and revised their widely influential estimations of the brooding elderly bishop. Looking back at his masterpiece, Brown recognizes that in his interpretation of the mature Augustine - the "truly oppressive," "severe and aggressive figure of authority"he had failed to appreciate "how little authority Augustine actually wielded over his hearers. $" 8$ Recognition of such limits has led Brown along with Robert Dodaro and Brent Shaw to ascribe even greater importance than had already been given to the role that rhetoric plays as Augustine constructs arguments intended to move Roman political officials, over whom he has no authority, to wield their power. ${ }^{9}$ For his part, Markus's early estimation perceived Augustine's proposals for ecclesial discipline as a "horrible doctrine" resulting from a tension between his commitment to a desacralized political

\footnotetext{
${ }^{7}$ Brown writes of the "lost future" that might have been if the Augustine of De libero arbitrio had won the decade-long "battle against regarding men as utterly helpless" (Brown, Augustine of Hippo, 145). Carol Harrison argues, in Rethinking Augustine's Early Theology, that Augustine's later theology demonstrates far more continuity with his early theology than is usually recognized.

${ }^{8}$ Brown, Augustine of Hippo, 446. Robert Dodaro and Brent Shaw share Brown's more recent appraisal of Augustine's relative lack of influence over his contemporaries (See Robert Dodaro, "The Secret Justice of God and the Gift of Humility," Augustinian Studies 34:1 (2003): 83-96; and Brent Shaw, "Augustine and Men of Imperial Power," [http://www.csc.org.il/template/default.aspx?PageId=107]).

${ }^{9}$ See Robert Dodaro, Christ and the Just Society in the Thought of Augustine (Cambridge: Cambridge University Press, 2004); Dodaro, "Augustine's Revision of the Heroic Ideal," Augustinian Studies 36:1 (2005): 141-157; and Brent D. Shaw, Sacred Violence: African Christians and Sectarian Hatred in the Age of Augustine (Cambridge: Cambridge University Press, 2011).
} 
sphere and his advocacy of state-sponsored coercion of religious dissent. ${ }^{10}$ More recently, Markus is less sanguine about identifying the former trajectory of secularization that he had associated with Augustine, including its conception of the secular that is particularly salutary to "modern secular liberalism."11 Brown and Markus have modified their appraisals in part due to the discovery of letters and sermons that have lent greater perspective on Augustine's context and his response to it, including a better understanding of to whom letters were addressed and where their recipients stood in the Roman imperial hierarchy, and in part due to a wave of scholarship that has generated significant advances in late-antique historiography. If such eminent scholars as Brown and Markus have re-examined basic features of their hugely influential contributions to Augustine scholarship, then scholars of Christian ethics for whom Augustine is but one influence among many might be forgiven for failing to arrive at sufficiently nuanced understandings that might generate a consensus regarding how best to interpret his ethics.

Lying and killing in Augustine's ethics

The expected diversity of interpretations among Christian ethicists is particularly evident in the approaches by which they engage apparent tensions between Augustine's ethics of lying, on the one hand, and his ethics of violent coercion, on the other. ${ }^{12}$

\footnotetext{
${ }^{10}$ Robert Markus, Saeculum: History and Society in the Thought of St. Augustine (Cambridge: Cambridge University Press, 1970), 142.

${ }^{11}$ Markus, Christianity and the Secular (Notre Dame: University of Notre Dame, 2006), 51. For his reconsiderations see Markus, Christianity and the Secular, 3, 12, and esp. Chapter 3, "Consensus in Augustine and the Liberal Tradition," 51-69.

${ }^{12}$ Of course, many scholars see no need to engage such tension or to search for a coherent interpretation in the two topics of Augustine's ethics. The tension is simply allowed to remain and the temptation to remedy or reconcile the tension is resisted. Some
} 
Scholars regularly observe that Augustine's absolute prohibition of lying appears to be in tension with the often-commented-on judgments regarding political and religious coercion. The responses to this alleged tension depend greatly on the constructive purpose of the given reader. Alain Epp Weaver, for example, embraces Augustine's position on lying — interpreted as an absolute prohibition of a sinful act — and then applies that reasoning to all acts of violence - including war and torture - in order to arrive at a pacifist position that, Weaver reasons, Augustine should have endorsed in order to become consistent with his better insights. ${ }^{13}$ Taking a very different approach, David Decosimo asserts that Augustine's justification of violence, limited to those who hold the relevant public office, provides a framework through which to discern the ethics of lying that Augustine actually held. He applies the early public/private distinction from a discussion of self-defense in De libero arbitrio (393) to his later moral reasoning regarding lying, with the result that Augustine's purported absolute prohibition of lying

scholars may find coherence a fool's errand, and intertextual systematization of unsystematic work inappropriately imports hermeneutics that were developed for reading sacred texts thought to constitute a coherent canon and which distort more than they reveal, at least when applied to non-Scriptural authors and texts. Others who are more critical of Augustine in particular may judge him to be beyond repair, suitable for critique and little more, and deem attempts to rescue his theological ethics exercises in futility. Still other may consider coherence itself a pernicious modern Enlightenment ideal that entails projecting alien normative interpretive lenses or frameworks back on figures and cultures whose integrity (or not) ought to be left intact without imposing "our" reconstructions upon them.

${ }^{13}$ Alain Epp Weaver, "Unjust Lies, Just Wars? A Christian Pacifist Conversation with Augustine," Journal of Religious Ethics 29:1 (2001): 51-78. Weaver treats Augustine's ethics of lying as analogous to his ethics of violence, suggests the ethics of lying are more coherent, and then transfers the logic of those ethics to violence as if there were a one-toone correspondence in the acts involved. 
becomes analogous to his prohibition of private killing in self-defense. ${ }^{14}$ According to Decosimo, lying by a public official is scarcely considered by Augustine (he suggests that the discussion of Joshua 8 in Quaestionem in heptateuchem 6.10-11 constitutes one instance) but we can discern what Augustine would have written, and actually held to be the case, by extrapolation.

Although their arguments run counter to one another, Weaver and Decosimo share a common aim: identifying an authentically Augustinian ethic that incorporates seemingly divergent ethics of lying and killing in war. They also share a common assumption: Augustine's ethics of lying and his ethics of violent coercion ought to be formally similar. ${ }^{15}$ That is, lying and violent coercion should be evaluated as morally analogous acts and the moral reasoning that applies to one act should apply equally to the other. The problem to be resolved, then, is the untenable disanalogous manner in which the two acts are framed as they are commonly interpreted by Augustine scholars who understand Augustine's position on lying as an absolute prohibition and his assessment of violent coercion as sometimes justified. Where Weaver and Decosimo disagree is in their estimation of where the fault for the tension between these two ethics lies and how best to resolve the apparent (Weaver) or alleged (Decosimo) conflict.

\footnotetext{
${ }^{14}$ David Decosimo, "Just Lies: Finding Augustine's Ethics of Public Lying in His Treatments of Lying and Killing," Journal of Religious Ethics 38:4 (2010): 661-697. This argument is anticipated but not advanced by John Rist: "if [an offence to God] is Augustine's concern, we may wonder whether official lying might not be justified and accepted in a similar way to official killing" (Rist, Augustine: Ancient Thought Baptized [Cambridge: Cambridge University Press, 1994], 195).

${ }^{15}$ Examining how an unusual case of seeming adultery appears less analogous to lying than killing, John Rist represents a scholarly consensus that considers lying and killing in Augustine's ethics as morally disanalogous acts: "Perhaps an analogue is to be found with killing more easily than lying, since lying, as a curiously religious offense like blasphemy and apostasy, may be always forbidden" (Rist, Augustine, 197).
} 
Weaver argues that the ethics of killing rightly attributed to Augustine require modification and ought to be brought into agreement with his ethics of lying. The result is an absolute prohibition of violent coercion analogous to his absolute prohibition of lying. Decosimo argues that a more careful reading of Augustine's ethics as a whole discloses that his ethics of lying are quite distinct from what Augustine's interpreters through the ages have thought. He holds that Augustine's ethics of lying are indeed analogous to his ethics of violent coercion: there is not an absolute prohibition of lying, as his interpreters have supposed, but merely a prohibition of lying in private (just as private citizens are prohibited from killing). Lying, like killing, is sanctioned only by a public magistrate and on the condition that one holds the requisite subordinate office. ${ }^{16}$

Weaver believes scholars have interpreted Augustine correctly and the fault for the inconsistency lies with Augustine. Decosimo believes that Augustine's ethics of lying and killing are coherent but that scholars have misinterpreted the ethics of lying with the result that Augustine is made to appear inconsistent. Weaver faults Augustine. Decosimo faults Augustine's interpreters. Neither considers the image of God and how it might illuminate the apparent conflict differently.

In what follows, I argue that the scholarly consensus regarding lying is correct (contra Decosimo) and that a careful reading of Augustine on lying, with attention to his conception of the imago trinitatis, shows how it is that he is able to hold together these allegedly divergent commitments (contra Weaver). Augustine maintains an absolute

\footnotetext{
${ }^{16}$ Yet another interpretation, advanced by John von Heyking, suggests that Augustine did not in fact hold an absolute prohibition of lying at all but instead affirms just lies in certain cases (von Heyking, Augustine and Politics as Longing in the World [Columbia, Mo.: University of Missouri Press, 2001], 114-120).
} 
prohibition on lying and allows that Christians are justified in assuming offices where they will engage in violent coercion. He is able to hold together these two affirmations, because these two acts are disanalogous in his moral reasoning - the logic that obtains in one moral judgment does not apply to the other act. How the two different moral judgments follow from a coherent form of moral reasoning is not self-evident however. The assessments of the two acts are only shown to be distinct in light of Augustine's moral anthropology and his understanding of the image of God therein.

The Augustinian "image of God" and religious ethics today My reading of Augustine's ethics does not seek to remedy his moral reasoning by merely recognizing or emphasizing the socially constructed, historically-accidental nature of his judgments. It is true, of course, that his moral judgments are formed in large part by the norms of his cultural context and that elements of his own theology in certain respects offer resources to overcome conclusions at which moderns with their sensibilities may cringe. ${ }^{17}$ Cultural norms certainly warrant historical and critical engagement of this sort. That task has been pursued to great effect by scholars interested to reconcile Augustine's core theological commitments and vision with modern sensibilities or U.N. declarations and covenants regarding torture, political violence, and religious coercion that are alien to the $5^{\text {th }}$ century bishop's writings (even if he did not anticipate how or that such codified norms would become a possibility). ${ }^{18}$ In the case of

\footnotetext{
${ }^{17}$ John Rist observes that "we are more likely than the ancients to be puzzled by Augustine's attitude" (Rist, Augustine, 199).

${ }^{18}$ See, for example, Markus, Saeculum; John Milbank, Theology and Social Theory: Beyond Secular Reason (Oxford: Blackwell Publishers Ltd, 1990); Eric Gregory, Politics
} 
lying and violent coercion, however, the difficulty with such attempts at rehabilitation is that whereas these features of political life were commonplace in late-antiquity, Augustine's position on lying manifests a readiness to depart radically from the cultural norms of his day.

More specifically, whereas the image of God has been invoked frequently in Christian and Jewish ethics as an analogue for "human dignity" in rhetoric surrounding human rights advocacy and legislation since World War II, the image of God, as Augustine develops it, does not establish religious liberty, freedom of conscience, rights to due process, a voice in representative governance, or a prohibition of torture. ${ }^{19}$ Instead, the image of God finds its center of ethical gravity in discourses about lying as it occurs in the rational soul.

Augustine's influential conception of the image of God coheres not only with his position on lying, but also with his acceptance of coercive force. This coherence suggests that theologians and ethicists who take exception to Augustine's ethics of coercion or lying while maintaining a prominent place for the image of God in their moral reasoning face a difficult question: How do they embrace Augustine's imago dei and not the ethics

and the Order of Love: An Augustinian Ethic of Democratic Citizenship (Chicago: University of Chicago Press, 2008); and Charles Mathewes, An Augustinian Theology of Public Life (Cambridge: Cambridge University Press, 2008).

${ }^{19}$ There is an expansive literature debating the genealogy and emergence of human rights. My own interpretation owes much to the "sacralization of the human person" thesis developed by the phenomenological sociologist, Hans Joas (i.e., the gradual elimination of the 'inhumane' treatment of human persons in punishment, torture, and religious persecution). See Hans Joas, The Sacredness of the Person: A New Genealogy of Human Rights, trans. Alex Skinner (Washington, D.C.: Georgetown University Press, 2013). See also Sam Moyn, The Last Utopia: Human Rights in History (Cambridge, Mass.: Belknap Press, 2010), and Jeremy Waldron, Dignity, Rank, and Rights (Oxford: Oxford University Press, 2012). 
of lying and/or coercion that he himself thinks follow from it? Much of contemporary interfaith and ecumenical ethical discourse around torture — as well as abortion, assisted suicide, and hate speech — appeals to the dignity that all human beings possess by virtue of having been created in the image of God. ${ }^{20}$ If Augustine's imago dei compares unfavorably with contemporary Christians', Jews', and Muslims' conceptions of the imago dei that generate a distinct set of moral norms and judgments that are more concerned with embodiment and safeguarding personal liberties, then these religionists do well to discern where their own conceptions of the imago dei are congruent with and where they depart from that of Augustine. Is an Augustinian account of the imago dei quite divergent from the assumptions undergirding contemporary human dignity discourse? Is his imago dei serviceable for modern human rights concerns, even if he is mistaken in the moral reasoning that he thinks it entails? If Augustine's ethics differ greatly from our own, does the difference lie in his conception of the imago dei, his other theological commitments, or perhaps even his scriptural hermeneutics?

Religious ethicists today might hypothesize that given his extensive attention to

${ }^{20}$ A tremendous diversity of perspectives on the relationship of the image of God to human dignity and human rights can be found in these volumes from the past decade: Christopher McCrudden, ed. Understanding Human Dignity, Proceedings of the British Academy (Oxford: Oxford University Press, 2014); Tal Howard, ed., Imago dei: Human Dignity in Ecumenical Perspective (Washington, DC: Catholic University of America Press, 2013); David Gushee, The Sacredness of Human Life: Why an Ancient Biblical Vision is Key to the World's Future (Grand Rapids, Mich.: Eerdmans, 2013); John Witte, Jr. and Frank S. Alexander, ed., Christianity and Human Rights: An Introduction (Cambridge: Cambridge University Press, 2011); Edmund D. Pellegrino, Adam Schulman, and Thomas W. Merrill, eds., Human Dignity and Bioethics (Notre Dame: University of Notre Dame Press, 2009); George Hunsinger, ed., Torture is a Moral Issue: Christians, Jews, Muslims, and People of Conscience Speak Out (Grand Rapids, Mich.: Eerdmans, 2008); Nicholas Wolterstorff, Justice: Rights and Wrongs (Princeton: Princeton University Press, 2008), esp. 342-361; R. Kendall Soulen and Linda Woodhead, God and Human Dignity (Grand Rapids: Eerdmans, 2006). 
scriptural statements regarding the image of God, Augustine ought to have affirmed an absolute prohibition of torture and allowed that in limited cases a noble lie might be justified. We might wish that Augustine had not been such a man of his time. Had he been able to overcome the socially-constructed reality of his age, he might have transcended its cultural norms, prohibiting religious persecution and torture as he had lying and murder. And, had Augustine arrived at such conclusions, perhaps his sizable historical influence might have contributed to an earlier and greater ecclesial reluctance or opposition to such practices of coercion, virtually eliminating them from Christendom. Some might even charge that except for Augustine's distortive vision, the Latin West might have arrived long ago at such conclusions as were eventually articulated in the 1948 Universal Declaration of Human Rights ${ }^{21}$ and the 1984 UN Convention against Torture $^{22}$ - international agreements declaring that there is no justification for torture and religious liberty is unassailable. Tragically, they might say, Augustine was a man of his time. Even if he laments the necessity of judicial use of torture, he explicitly refutes the Pelagian opinion that the image of God requires the recognition of religious liberty. ${ }^{23}$ And so it is left to us to repair his failings where he did not follow his best insights and where he did not take his doctrine of the image of God to its logical conclusion. Or so the

21 "Everyone has the right to freedom of thought, conscience and religion; this right includes freedom to change his religion or belief, and freedom, either alone or in community with others and in public or private, to manifest his religion or belief in teaching, practice, worship and observance" (UDHR, Article 18, U.N. General Assembly 1948).

22 "No exceptional circumstances whatsoever, whether a state of war or a threat of war, internal political instability or any other public emergency, may be invoked as a justification of torture" (Convention against Torture and other Cruel, Inhuman or Degrading Treatment or Punishment, Part 1, Article 2.2, U.N. General Assembly 1984).

${ }^{23}$ See civ. 19.6; c. Iul imp. 5.38. 
argument seems to go with respect to Augustine's acquiescence to coercive violence.

What if this story is wrong, however? What if the problem is not that Augustine uncritically accepts the cultural norms of his day, but rather that he has substantive reasons for the more permissive limits on physical violence, reasons related to basic theological commitments pertaining to divine ontology, theological method, and human beings as created in the image of God. If he has warranted reasons for his positions, then our critical task will demand a more thoroughgoing examination of his underlying commitments, and we will want to pursue an alternative that identifies where Augustine's logic is deficient. Were we unable to do so, then the question would remain open as to whether it is he or modern religious ethicists who fail to critically assess the relationship between the image of God and violent coercion.

In fact, Augustine was not at all unreflective in his absolute prohibition of lying or limited endorsement of torture and religious coercion. Augustine was well aware that he was out of step with Christian, Jewish, and pagan philosophers even in his own day with regard to his judgments about these issues. He regularly takes up and refutes others' arguments and policies, positions often still advanced today, where they arrive at conclusions different from his own. His variously articulated theological anthropology facilitates and helps to explain his often counter-intuitive teachings. It is an anthropology heavily dependent upon and highly consistent with his doctrines of God and the Trinity. By his lights, the image of God does not prohibit violence - far from it. His anthropology provides good reasons to treat lying like murder (they are inherently unjust acts) and torture like killing (they are not inherently unjust, rather their moral species is undetermined). When and where necessity demands, it would be unjust not to kill, not to 
torture. ${ }^{24}$ Because lying is always unjust, like murder, it is always prohibited. Why is this? Answering that question requires that we discern what Augustine understands the image of God to be and to require of human beings in their relationships to one another.

The image of God in Augustine's ethics

Augustine's conception of the image of God holds explanatory power that helps to untangle related problems in his moral reasoning for which scholars have struggled to give an account. My project follows the questions raised and addressed by Augustine regarding lying and its relationship to the image of God: Is it justifiable to tell a lieperhaps to save a human life, to bring about someone's eternal salvation, or to fulfill the role-specific duties of one's public office? The broad consensus among scholars is that Augustine's consistent answer to this question is, "No." Regardless of the circumstances (and contrary to the minority report of Decosimo and von Heyking), Augustine's position is that all lies are sins, and one should never tell a lie. ${ }^{25}$ In what follows, I explore how the image of God gives shape to Augustine's moral reasoning that arrives at this conclusion. My contention is that the image of God holds explanatory power for understanding Augustine's ethics and that this doctrine serves to demonstrate the internal

\footnotetext{
${ }^{24}$ To say that person A killed person B tells us nothing about whether this killing was a just act. To say that person $A$ murdered person $B$, on the other hand, provides the moral species of the act in the label. For Augustine, naming an act "torture" does not yet tell us whether it was just or unjust in this particular case to inflict suffering in order to extract desired information. Today, of course, accusations of torture nearly always assume its moral specification as unjust. Witness the efforts undertaken to label information extraction by means of inflicting pain and suffering as "enhanced interrogation techniques" rather than "torture."

${ }^{25}$ A dissenting minority, John von Heyking and David Decosimo, disagrees among themselves as to how exceptions to an absolute prohibition of lying might arise. See von Heyking, Augustine and Politics, 114-120, and Decosimo, “Just Lies," 661-697.
} 
coherence of Augustine's ethics, which both upholds an absolute prohibition of lying and motivates and limits forms of religious coercion. Here, distinctions developed over the course of Augustine's writings on the image of God prove to be morally salient.

In looking at the relationship between the image of God and Augustine's moral reasoning regarding issues of lying and coercion, I want to explore the possibility that disagreement with Augustine's judgments on these practical questions might entail far greater departures from his basic theological commitments than is often recognized. I argue that if we find ourselves in disagreement with Augustine about lying then it is likely we will also find basic elements of his account of the image of God unpersuasive. That the image of God is integral to Augustine's ethics of lying sheds significant light on the proposals and potential problems of appealing to Augustine's image of God within contemporary moral discourses about its relationship to human dignity's sources and uses.

Recall Paul Griffiths' argument that Christians ought not expect Augustine’s moral reasoning regarding lying to persuade non-Christians: "such persuasion would require assent to a large number of truths about God's nature and the image of God in us, for Augustine thinks that what he argues about the lie presupposes the truth of such Christian convictions."26 Indeed, Augustine's position regarding lying has proven unpersuasive not only to non-Christians, but to most Christians as well. ${ }^{27}$ The cause is not advanced by Griffiths' putting quite a fine point on the matter with a ticking-time-bomblike scenario:

\footnotetext{
${ }^{26}$ Griffiths, Lying, 15.

${ }^{27}$ See Boniface Ramsey, "Two Traditions of Lying and Deception in the Early Church," Thomist: a Speculative Quarterly Review 49:4 (1985): 504-533.
} 
A million innocent lives against the lie ... Only Augustine would accept the terms and ban the lie. The consistent Augustinian cannot lie to save innocent life, whether one or a million ... Should I lie to save the life of my child? No. Should I lie to prevent war, encourage peace, soothe the weary and discouraged, instruct the foolish, or liberate the innocent from torture? No. ${ }^{28}$

If Griffiths is right, then Augustine's ethics that derive from the image of God are at odds with the way in which many religious ethicists and human rights discourses today deploy the image of God term for their purposes.

Our purpose is not so much to advocate or castigate Augustine's understanding of the divine nature and image of God but to understand how the image of God functions within his moral reasoning regarding lying (and by extension other analogous or disanalogous forms of coercion). ${ }^{29}$ We will be interested not only in those places where Augustine refers to the imago dei, though we will attend to those, but also, and perhaps more importantly, we will consider how the several distinctions Augustine develops in his theological expositions of the image of God are manifest in and contribute to his arguments regarding lying in its various instantiations as well as moral reasoning about human action in general.

Because our interest is in how the image of God gives shape to Augustine's moral

${ }^{28}$ Griffiths, Lying, 230.

${ }^{29}$ Within Augustine's agent-based ethic, what is essential to coercion [cohercitio] is the knowledge and will of the agent doing the coercing that his or her action will influence the action of another person to which the other person would not consent. Lying to another person would count as coercion where it meets this criterion. Whether a person is aware that they are being coerced by the appetitive, intellectual, verbal, or physical proddings of another has no bearing on whether the act would count as coercion. For Augustine, coercion can be justified, as we will see, in cases of necessity, whereas lying is never justified. So, forms of coercion analogous to lying, morally speaking, would include all unjustified (i.e., sinful) instances of coercion. Lying is disanalogous to justified coercion. We will return to the issue of necessity below. 
reasoning, that Augustine arrives at the conclusions he does is not nearly as important for our purposes as how-i.e., the ways in which commitments about the image of God inform his moral reasoning toward specific conclusions. In particular, I aim to show that his understanding of the image of God shapes Augustine's reasoning about the element of an intention to deceive (voluntate fallendi) that he takes to be a necessary feature of every lie and also the non-necessity of spoken words for an act to constitute a lie. These aspects of Augustine's ethics of lying are often misunderstood both by his advocates and by those who dismiss, explain away, or allege inconsistencies regarding basic elements of his ethics. ${ }^{30}$ The implications of this latter claim are complex and will be clarified in the course of our investigation. For, even if Augustine's theological anthropology and the image of God therein prove basic to one or more of his conclusions about lying and coercion, the multiple facets to the image of God as he conceives of it will require that we address which elements(s) of the image of God are relevant and/or determinative for the particular ethical question under consideration.

We will want to examine closely the moral reasoning most proximate to Augustine's mature exposition of the image of God in De Trinitate Book 14 not only most proximate textually, but also most proximate in the hierarchy of goods - namely, the transition from the image of the Trinity to the Trinity itself in Book 15 and the discussion of lying therein. Subsequent to his investigation of the image of the Trinity in the human mind, the moral issue that immediately arises in relation to the image of God is not one of torture, human dignity, freedom of religion, or other rights that human

\footnotetext{
${ }^{30}$ Below, I aim to improve upon the interpretations offered by and to clarify disagreements between Griffiths and Decosimo.
} 
beings are due by virtue of their creation in the image of God (as is the case in much of contemporary religious ethics), but, rather, questions of agential falsehood that result from ignorance, error, and lying. Consideration of Augustine's discussion of lying in $D e$ Trinitate 15 serves to clarify elements of his earlier writings on lying that are more often consulted for and presented as his more comprehensive moral reasoning on this topice.g., Epistula 28 (394), Enarrationes in Psalmos 5 (394), De mendacio (395), Epistula 82 (405), Contra mendacium (420), and Enchiridion (422). For this reason, and in order to cast his later ethics in greater relief, we will return to one thread that runs throughout these texts - the "yes, yes; no, no" of Mt 5.37—subsequent to examining the Trinitarian and Christological exposition of lying in De Trinitate 15.

Augustine's later writings on lying from the 420's move us from seemingly theoretical questions to manifestly practical issues of coercion. And, during Augustine's exposition of the image of God in De Trinitate 11-14 especially, a more integrated moral imaginary emerges connecting quite explicitly the image of God and Augustine's ethic of lying.

The image of God in Scriptural texts on lying

Before diving into a textual analysis of lying in De Trinitate 15, it is worth pausing to reflect upon some of the potential oddities of drawing an intimate connection between the image of God and lying. Most of the scholarship in Christian ethics today that draws upon the imago dei deploys this concept for the purpose of opposing practices and policies having to do with killing or bodily harm in one form or another-abortion, physician-assisted suicide, euthanasia, capital punishment, torture, etc. The text of Gen 
9.6 makes a suggestive connection along these lines that Jewish and Christian thinkers have turned to for centuries_- "Whoever sheds the blood of a human, by a human shall that person's blood be shed; for in God's own image God made humankind." It is worth noting immediately that Augustine never quotes this historically influential text from Genesis anywhere in his entire corpus, in spite of the fact that he returned to the earlier chapters of Genesis quite often and was in the habit of quoting extensively from the Old Testament. That he fails to do so may help to explain, at least in part, why his own ethical conclusions about the image of God revolve around lying whereas figures before and after him had associated the image of God with issues of violence and bloodshed. ${ }^{31}$

Yet another apparent oddity is that Augustine never mentions the image of God in his treatises on lying (other than in De Trinitate 15). ${ }^{32}$ Augustine's failure to connect lying to the image of God in these writings is all the more remarkable for the intimate relationship between the image of God and lying in Scripture, a connection that occurs more often than that between killing and the image of God. Two passages central to Augustine's conception of the imago dei, Col 3.9-10 and Eph 4.23-24, include prohibitions of lying in immediate proximity to their references to the image of God. These two passages read as follows:

Do not lie to one another. Strip off the old man with his deeds and put on the new one that is being renewed unto perfect knowledge of God according to the image of Him who created him (Col 3.9-10).

As the truth is in Jesus, you are to put off, in line with your previous habits, the old man, the one who is being corrupted on the lines of deceitful desires. But be

${ }^{31}$ See, for example, Lactantius, Divine Institutes 6.10; Chrysostom, Homilies on Genesis 27.15; Ephrem the Syrian, Commentary on Genesis, 6.15.1-2.

${ }^{32}$ Among the hundreds of references to the image of God, Augustine refers to lying in $o p$. mon. 32.40; ep. Io. tr. 1.9; 5.12-13; and s. 107. 
renewed in the spirit of your minds, and put on the new man, the one who in accordance with God was created in justice and true holiness. Put away lying and speak truth each one with his neighbor, because we are members of one another (Eph 4.22-25). ${ }^{33}$

James 3.9 draws a similar parallel between lying and the human likeness to God.

With it we bless our God and Father and with it we curse man who was created in the image of God (Jas 3.9). ${ }^{34}$

It is remarkable that Augustine makes so little of Eph 4.25, Col 3.9a, and Jas 3.9 given his extensive attention both to questions of lying and the image of God throughout his writing career. Augustine seems to have cited Jas 3.9 only once in a sermon in Carthage (s. 16A, 411), then in Speculum (427), and in revising De Genesi ad litteram liber imperfectus (428). On the rare occasions that Augustine quotes Eph 4.25, he never discusses the image of God. ${ }^{35}$ In Contra mendacium a discussion that cites Eph 4.25 does allude to the inner human / outer human distinction (2 Cor 4.16) that he was pursuing as he simultaneously worked on De Trinitate. Even there, Augustine neither mentions the image of God nor does he incorporate Col 3.9a. And, in the rare cases that he cites Col 3.9a or Eph 4.25 Augustine never draws upon or quotes Eph 4.22-24 or the latter part of Col 3.9b-10 to introduce the image of God as among the various reasons for the prohibition of lying. As a result, he never mentions the image of God as a reason for lying's prohibition in any of his treatises on lying prior to De Trinitate 15. Finally, even

\footnotetext{
${ }^{33}$ Recall that Augustine equates and harmonizes "according to the image" (Col 3.10) and "in the spirit of your minds" (Eph 4.24) (See Gn. litt. 3.20.30).

${ }^{34}$ This rendering of James 3.9 comes from $s$. 16A (411), the sole quotation of the verse in Augustine's corpus prior to Speculum. It substitutes ad imaginem dei for ad similitudinem $d e i$, a substitution of which Augustine was certainly capable during the 400-413 period of his writings when the distinction between imago and similitude was not a major concern. In Speculum and in his addendum to Gn. litt. inp. (428), Augustine's text reads as does the Vulgate: qui ad similitudinem dei facti sunt.

${ }^{35}$ See, for example, mend. 5.6, c. mend. 2.2, 6.15.
} 
in De Trinitate, the connection between the image of God and lying in these three scriptural texts is not explored. Nowhere during his extensive investigation of the imago dei in De Trinitate does Augustine quote the prohibitions of lying in Col 3.9a or Eph 4.25, even as he cites portions of Col 3.9b-10 and Eph 4.23-24 more than a dozen times. Collectively, all of this seems to suggest that in spite of several scriptural warrants, the intimate proximity of references to the imago dei to the prohibitions of lying in Col 3:9a, Eph 4:25, and Jas 3:9 did not play a major role in Augustine's reasoning for the prohibition of lying and, conversely, that the prohibition of lying was not a primary concern in Augustine's development of his account of the image of God. Indeed, these two concerns - developing a theological account of the imago dei and a robust prohibition of lying — proceed along largely parallel tracks until their intersection in $D e$ Trinitate 15, making this late confluence more than a little curious.

As we will see, the catalyst for examining the ethics of lying in relation to the image of God in De Trinitate 15 does not derive from any of the scriptural texts that explicate this connection. Instead, Augustine introduces here in De Trinitate 15 a text of unique importance to his earlier expositions of lying, modifying its previous interpretations and giving it an unprecedented Trinitarian and Christological meaning. 
II.2 Lying After the Image of God: De Trinitate 15

The analogy between the rational soul and the Trinity: Its basis and limits

Augustine begins De Trinitate 15 (c. 426) with a series of reminders about the aims of the intellectual exercise through which his book guides the reader. The purpose of the exercise has been to train readers in the recognition of several affirmations and distinctions: 1) the generation of the Son from the Father as distinct from the procession of the Holy Spirit from the Father and the Son; 2) human nature consists of body and soul, and the mind is not the entire soul but only its highest part - the rational soul [animus] consists of the irrational part of the soul [anima] held in common with the beasts plus the mind [mens] that is common to humans and angels; 3) although human beings are rightly said to be the "image of God," it is with respect to the mind or rational part of the soul — and not the body or the lesser parts of the soul — that human beings are so called; and, combining points $1-3,4$ ) the image of God in the mind demonstrates to natural reason what Scripture teaches and the Catholic faith affirms regarding the distinction between generation and procession in the Trinity itself. ${ }^{36}$ Augustine intends De Trinitate to serve as a reading exercise that teaches these doctrines to both pagans and Catholics in order that they might grow in faith and wisdom by increasing both understanding of and love for the triune God. ${ }^{37}$

In pursuance of our plan to train [exercere] the reader, in the things that

\footnotetext{
${ }^{36}$ The affirmation of agreement between scripture and natural reason traces back to Acad. 3.20.43.

${ }^{37}$ See Roland Kany's argument that Augustine's intended audience included those who were "skeptical about Christianity" and "that he normally had unbelievers in mind as well [as believers]" ("De Trinitate" in Karla Pollmann and Willemien Otten, eds., The Oxford Guide to the Historical Reception of Augustine, Vol 1 [Oxford: Oxford University Press, 2013], 387-399).
} 
have been made (Rom 1.20), for getting to know him by whom we were made, we came eventually to his image. This is man insofar as he excels other animals, that is in his reason or understanding and in whatever else can be said about the rational or intellectual soul that may belong to what is called "mind" [mens] or "rational soul" [animus]. Several Latin authors have used this latter word, animus, to distinguish what is pre-eminent in man and not found in beasts by a proper name of its own from the soul, anima, which is in man and beasts alike. ${ }^{38}$

Before investigating the relationship between right doctrine regarding the Trinity and the image of the Trinity in the human mind, Augustine offers an apology for his method quoting Rom 1.20, a locus classicus for later Christian natural theology. ${ }^{39}$

Augustine locates his interpretation of Rom 1.20 alongside a longer text from the Book of Wisdom in the Apocrypha. Read together-Wis 13.1-5 functioning as a gloss or parallel of Rom 1.20 - they provide scriptural warrants for the method of reasoning from the creation to the attributes of its Creator, its Most Just Orderer (iustissimus ordinator). Anticipating that some Christians will dismiss his approach and its novelty—seeking an understanding of the processions of the Trinity through an enquiry that culminates in the self-reflexive knowing of the human mind-Augustine offers these scriptural texts in the hope of appeasing real or imagined objections.

The book of Wisdom rebukes those who from the good things that are seen were unable to know him who is, and did not recognize the craftsmen

${ }^{38}$ Trin. 15.1.1.

39 Augustine's argumentative purpose in citing Rom 1.20 differs from Paul's. Paul does not construct from attributes of the creature an understanding of the divine substance or Trinitarian relations. Rather, writing to those Romans whose "faith is being reported all over the world" (Rom 1.8), he suggests that the divine attributes of beauty and power reminds these Christians that they, like the godless, are "without excuse" (Rom 2.1). Paul's argument in Rom 1.20-2.1 calls Christians to recognize themselves as those who fail to honor and thank God, as those who are not justified in judging others for doing what they themselves have done, as those who "exchanged the glory of the immortal God for images resembling mortal man or birds or animals or reptiles." See also, spir. et. litt. 19.12 . 
by looking at his works, but thought that either fire or wind or whirling air or the circuit of the stars or the violence of the waters or the luminaries of heaven are the gods that rule the world. If they thought them gods because they were ravished by their beauty, let them know how much better is their Lord; it was the begetter of beauty that created them. Or if they were amazed at their might and their activity, they should understand from these how much stronger is he who established them. For from the greatness of the beauty and of the creature the creator of these things can knowably be seen (Wis 13.1-5). I quote this passage from the book of Wisdom in case any of the faithful should reckon I have been wasting time for nothing in first searching for signs of that supreme Trinity we are looking for when we are looking for God, going step by step through various trinities of different sorts until we eventually arrive at the mind of man. $^{40}$

The discerning hermeneut perceives Scripture pointing to the human mind as an image of the Trinity and thus discovers this site to be a uniquely suited locus of investigation into the nature and attributes of the Triune God. Augustine is well aware that his Scriptures never refer to God as "Trinity" or explicitly assert the mind is the "image of God." Nevertheless, an attentive synthetic reading of Scripture leads to both affirmations and, he argues, both are confirmed by a careful examination of the creation by an enspirited mind.

In all God's creation, the rational soul's attributes reflect the Trinity's attributes more than any other creature. Contemplating the Trinity, however, is no easy task, and arriving at accurate conclusions requires training. Even the mind's self-examination, as a preliminary reflection on the Trinity, must be worked toward after exercising itself on lesser trinities:

We turned ourselves back in reflection, between the beginning and completion of our search, to what could be called the more familiar consideration of our own mind insofar as man has been made to the image

${ }^{40}$ Trin. 15.2.3.

${ }^{41}$ See op. mon. 32.40 . 
of God. And from then on we lingered over the creature which we ourselves are from the ninth to the fourteenth book in order to perceive if we could the invisible things of God by understanding them through those that have been made. ${ }^{42}$

There are many "likenesses that are useful for understanding God with, as far as this is possible; but of such likenesses none is more suitable than the one which is not called God's image for nothing." ${ }^{, 43}$ The mind, as the image of God, manifests a greater likeness in its attributes to the Trinity than any of its other vestiges either in the several lower trinities in the human or in the rest of creation. Most important among these attributes of the image of God are the four of co-equality, consubstantiality, incorporeality, and the capacity of its nature for contemplation of eternal things. ${ }^{44}$ These attributes evidence the mind's unsurpassed nearness/likeness to God, and it is due to them that scripture points

${ }^{42}$ Trin. 15.6.10.

${ }^{43}$ Trin. 15.9.16. Later theologians would reaffirm this claim - that there is no subject matter more appropriate for discerning what God is like than the image of God-but with a different account of the image of God. Modern critiques would affirm turning to the image of God but reject both Augustine's dependence upon Greek philosophy that discovers in the rational soul that which distinguishes human nature as sui generis and also his synthetic interpretation of Col 3.10 and Eph 4.24 that posits the rational soul as the image of God. Tanner, Barth, Hauerwas, and Kelsey follow Luther and Calvin, as well as Barth and Rahner, in denying that the rational soul constitutes an imago trinitatis. Modern theologians more often assert that Jesus Christ (qua incarnate Christ) is the image of God. Where Christ's bodily existence is understood as the image of God, rather than the rational soul, these modern theologians might repeat Augustine's affirmation that among the "likenesses that are useful for understanding God with ... none is more suitable than the one which is not called God's image for nothing," but with different results where their doctrines of God and the Trinity are concerned. From these revisions of the meaning of the image of God often follow extensive critiques of Augustine's doctrine of God on nearly every front, including the divine attributes of unity, simplicity, impassibility, and immutability, as well as the inseparable operations and the differentiation of persons based upon modes of origination.

${ }^{44}$ See Trin. 15.3.5. See also the four principles of Trinitarian ontology-unity of essentia, threefoldness, radical equality, and mutual relatedness - in Johannes Brachtendorf, Die Struktur des menschlichen Geistes nach Augustinus: Selbstreflexion und Erknenntnis Gottes in "De Trinitate” (Hamburg: Meiner, 2000), 56-78. 
the human mind to itself, according to Augustine, as the site par excellence for investigation into the mystery of the divine Trinity.

If the image of God is to provide useful knowledge about the triune God even as it retains important differences, then it becomes necessary to identify the possibilities and limits of the image of God as a source and means of knowledge of God. Thus, having argued for the methodological legitimacy of seeking greater understanding of the Trinity by looking at its image in the human mind, Augustine immediately cautions the reader regarding the important respects in which the human mind differs from the Trinity in both substantial and relational predications. Whereas the divine nature is simple, eternal, unchangeable, and ineffable, the image of God in the human exhibits none of these four perfections. The image of God is not simple but part of a composite human nature; it is immortal but not eternal; it is mutable and passible, susceptible to concupiscence; and it is comprehensible, even if not absolutely so (insofar as it is immediately present to itself) and even if its intellectual faculties have become incapable of perfect functioning as a consequence of the Fall. ${ }^{45}$ Contemplation of the image of God holds little promise for a greater understanding of these four particular attributes of the divine nature.

Not only does the mind's nature differ from the divine nature in these respects, but there is also a great chasm between the manner in which relational predications apply to the Trinity and to its image in the human mind. Whereas the triune God simply is Father, Son, and Holy Spirit, one God in three Persons, the composite image of God in the human is not simply identical to, but rather is merely part of the human person. And,

\footnotetext{
${ }^{45}$ See Trin. 15.16.26 for Augustine's speculation as to whether the mind will be capable in the eschaton of knowing itself completely, simultaneously knowing all that it knows.
} 
unlike the grammar of the Trinity, in which the three persons operate inseparably-in the unity of a single mind, will, and energy of operation - a human person relates to other persons with whom its mind, will, and energy of operation are not consubstantial or coequal in all respects, but are at best united in agreement with respect to motivation, intentions, and ends. ${ }^{46}$ Furthermore, whereas the simple divine nature is identical to the unity of Father, Son, and Holy Spirit, and the human mind's memory, intellect, and will constitute the mind itself, the trinity of the rational soul is not identical with human nature as such but merely one part of a larger composite nature. ${ }^{47}$ In each of these three ways - 1) the image of the Trinity is a composite of memory, intellect, and will; 2) human persons are not consubstantial with each other and thus lack the simple unity of a single mind, intellect, will, and energy of operation; and 3) the human person is a composite of which the image of the Trinity is but a part-human persons differ from the divine persons' relational predications. Augustine returns to these differences later in Book 15 where he takes up questions related to the ethics of lying.

In short, although among all created things the human mind manifests the greatest resemblance to the Trinity, there yet remains a basic Creator-creature distinction such that analogies drawn between the human mind and the divine nature require careful qualification. Identifying precisely what knowledge of the triune God can be derived from the rational soul, qua image of the Trinity, requires recognizing not only that it is the image of God but also those respects in which it is disanalogous and accounting for all of the necessary qualifications and moral implications.

\footnotetext{
${ }^{46}$ See Trin. 15.7.11, inter alia.

${ }^{47}$ See Trin. 15.7.12. Similarly, "That trinity which is God cannot just be read off from those three things which we have pointed out in the trinity of our minds" (Trin. 15.17.28).
} 
Immanent Trinitarian processions and the economic Christological mission

After distinguishing those substantial and relational attributes that the image of God shares with the divine nature from those it lacks, Augustine returns to the distinctive ways that the image of God manifests instructive discernable analogies to the Trinitarian processions as well as to the divine mission of the Son during his historical incarnation as Jesus of Nazareth. In the respective divine and human processes of generating or begetting a "word," the human mind does indeed discover itself to be an image and likeness of the Trinity it seeks to contemplate.

For Augustine, the persons of the Trinity are distinguished not substantially (they are consubstantial) but in their distinct modes of origination, by the distinction between the processions of the persons in relation to one another. The Father is the only person of whom it is true that from this person both of the other persons proceed. The Son is the only person of whom it is true both that this person proceeds from another person (the Father) and that from this person another proceeds (the Spirit). ${ }^{48}$ The Spirit is the only person of whom it is true that this person proceeds from both of the other persons and of whom it is true that this person forms the bond of unity between the other two persons. Augustine has these Trinitarian dynamics in view as he investigates the generation of words in the rational soul.

What Augustine is "trying to do is somehow to see him by whom we were made by means of this image which we ourselves are, as through a mirror." 49 As the mind

\footnotetext{
${ }^{48}$ Of course, Augustine affirms the filioque.

${ }^{49}$ Trin. 15.8.14.
} 
contemplates its own process of generating words, it is reflecting upon the nearest analogue to the Trinity that exists - nearest in the sense of similarity, but also nearest in its immediate proximity to itself. The mind actively images the processions of the Trinity when its self-knowing produces an accurate understanding of itself such that it loves itself as the image of God that it is.

Paul's statement "We now see through a mirror in an enigma, but then it will be face to face (1 Cor 13.12)" —where "mirror" refers to "image" and "enigma" refers to "likeness"-indicates that whatever the mind's eye perceives, it perceives through the very image of God. The twin processes of thinking and, subsequently, of generating communicative words together shed light, first, on the eternal generation of the Word of God in relation to the procession of the Spirit and, second, on the assumption of a human nature by the Word of God, the Incarnation. Augustine thus distinguishes between two basic types of words generated by the human mind that index the Word of God in what would come to be known as immanent and economic trinities, respectively.

First, there is the word uttered inwardly that precedes all signs and significations needed in order to communicate this word to another. These are pre-linguistic words in the thinking mind, "begotten of the knowledge abiding in the rational soul, when this knowledge is uttered inwardly just as it is." ${ }^{50}$ Such words derive from truths or ideas capable of being retrieved from the memory, where they are readily available for the mind's active knowing, should the mind desire/will to bring them forward into the

${ }^{50}$ Trin. 15.11.20. 
conscious thinking attention. ${ }^{51}$ In a perfectly functioning mind, this first word is a faithful representation of a truth generated from the memory through the mind's remembering, knowing, and willing this truth in the process of thinking. ${ }^{52}$ Augustine considers the generation of such a word analogous to that of the immanent procession of the eternally begotten Word of God, the second person of the Trinity. ${ }^{53}$ The will, in this case of a prelinguistic word generated in the mind's thinking attention, establishes a unifying bond of agreement between the truth known from memory and the true word generated by and from this truth as it is being thought by the intellect. This true word serves as the basis from which a second word is measured as either constituting a lie or not.

The second type of word is that which has assumed a sign appropriate for communication through language and the senses. This second word may be expressed sensibly, visually or audibly, but it is no less a second, distinct word if it remains in the thinking mind without being expressed sensibly. Compared to the first word, it differs

51 "a word can be, not only before it is spoken aloud, but even before the images of its sounds are turned over in thought - this is the word that belongs to no language" (Trin. 15.10.19).

52 "Even if no words are spoken, the man who is thinking is of course uttering in his heart. ... saying to oneself and in one's heart is a saying by thinking. ... So, thoughts are a kind of utterance of the heart" (Trin. 15.10.17-18). "For when we utter something true, that is when we utter what we know, a word is necessarily born from the knowledge which we hold in the memory, a word which is absolutely the same kind of thing as the knowledge it is born from. It [the word] is the thought formed from the thing we know [the pre-linguistic word] that is the word which we utter in the heart, a word that is neither Greek nor Latin nor any other language; but when it is necessary to convey the knowledge in the language of those we are speaking to, some sign is adopted to signify this word. And usually a sound, sometimes also a gesture is presented, the one to their ears and the other to their eyes, in order that bodily [sensible] signs may make the word we carry in our minds known to their bodily senses [auditory and oratory]" (Trin. 15.10.19).

53 "if anyone, I say, can understand this, he can already see through this mirror [image] and in this enigma some likeness of that Word of which it is said, In the beginning was the Word, and the Word was with God, and the Word was God (Jn 1.1)" (Trin. 15.10.19). 
primarily not in that it is expressed sensibly but in that it is a word to which a sign has been attached. The primary referent of the term "word" is the first pre-linguistic word generated in thought rather than this second word that represents the first word by taking on the form of a particular sensible sign. Importantly, when uttered in the mind, the second type of word already includes the signifier of a particular language, the verbal sign it takes in communicating to others. Should the word which has assumed a sign be expressed sensibly to others, it is the mind that willfully both determines what sensible sign will be used and decides the sensible means of manifesting to others the word initially generated in the mind. "The vocal sounds of our speech are signs of the things we are thinking of. Thus the word which makes a sound outside is the sign of the word which lights up inside, and it is this latter, pre-linguistic word that primarily deserves the name of "word.",54 The sign-assuming word is paradigmatically borne outward to others by speech, though this is by no means the only way of signifying the word generated in thinking attention. ${ }^{55}$ Signification of a word can also assume other sensible representations such as written words and bodily gestures. Regardless of the sensible form of manifestation, whereas the first, pre-linguistic word is analogous to the eternally begotten Word of God, the second, sign-assuming word is analogous to the Word that assumes flesh, the incarnate Word that takes a temporal, human form. ${ }^{56}$

\footnotetext{
${ }^{54}$ Trin. 15.10.19-11.20.

${ }^{55}$ Augustine repeatedly affirms the possibility that the second word's signification might be expressed sensibly through audible speech and/or through bodily gestures (see Trin. 9.7.12; 15.10.19; c. mend. 10.24-13.28).

${ }^{56}$ With respect to the second word, see Jn 1.14 and Phil 2.3-8. "Our word becomes a bodily sound by assuming that in which it is manifested to the senses of men, just as the Word of God became flesh by assuming that in which it too could be manifested to the senses of men. And just as our word becomes sound without being changed into sound,
} 
So, the mind as an image of the Trinity generates these two types of words-a pre-linguistic word generated from the memory and a sign-assuming word capable of sensible expression — whose distinction promises to aid in attaining a greater understanding of the Trinity, especially its processions and missions but also certain of its substantial and relational attributes. For both types of words, the idea or truth to which the word refers is present in the memory even if it is not actively uttered by the thinking mind. Lacking not only omniscience but also perfect self-awareness, the mind generates words in the recesses of the heart even when it is not actively aware of them as objects of its conscious attention. The mind's memory is a great storehouse of knowledge, containing a vast amount of understanding capable of being brought to mind - truths that can be thought in the mind's conscious attention — though the mind is not capable of actively attending to all of these truths simultaneously, at least not in this life. ${ }^{57}$

For the purpose of understanding the second person of the Trinity (the Word of God both in its immanent generation from the Father and in its economic assumption of a human nature) through investigation of the created image of the Trinity (the human mind's generating of a pre-linguistic word and its assumption of a sensible sign), it is necessary to differentiate between the first and second human words. Human words are useful for contemplating the Trinity where there is a recognition of the distinction between the pre-linguistic and sign-assuming types of human words.

Therefore if you wish to arrive at some kind of likeness of the Word of

so the Word of God became flesh, but it is unthinkable that it should have been changed into flesh. It is by assuming it, not by being consumed into it, that both our word becomes sound and that Word became flesh" (Trin. 15.11.20).

${ }^{57}$ See Trin. 15.16.26 for Augustine's speculation as to the whether in the eschaton the rational soul will be able simultaneously to attend to all of the truth that it knows. 
God, however unlike it may be in many ways, do not look at that word of ours which sounds in the ears, neither when it is uttered vocally or when it is thought of silently. ... And so we must come to that word of man, the word of a rational animal, the word of the image of God which is not born of God but made by God, the word which is neither uttered in sound nor thought of in the likeness of sound which necessarily belongs to some language, but which precedes all the signs that signify it and is begotten of the knowledge abiding in the consciousness, when this knowledge is uttered inwardly just exactly as it is. ${ }^{58}$

It is the first, pre-linguistic word and not the second, signifying word to which the eternal Word of God is analogous. The second, signifying word is analogous to the temporal incarnation of the Word of God.

The Trinitarian pre-linguistic "yes, yes; no, no"

Augustine draws two analogies to consider how the first, pre-linguistic word and the second, sign-assuming word in the rational soul are related to the procession of the Son (qua Word of God) and the works of God ad extra done through the Word of God. These analogies make use of Trinitarian and Christological dynamics in order to explicate Mt 5.37, the verse to which Augustine appeals most consistently in his writings on lying. ${ }^{59}$ The distinctive shape Trinitarian and Christological reflection upon the image of God gives to the moral reasoning regarding lying becomes increasingly apparent when the use Augustine makes of Mt 5.37 in De Trinitate is compared to earlier expositions. For this reason, we will return to Augustine's gradual reinterpretation of this verse below for the helpful way in which its interpretation draws out developments in Augustine's ethics of lying. As we will see, it also proves useful in arbitrating between and critiqueing

${ }^{58}$ Trin. 15.11.20.

${ }^{59}$ See Appendix B. 
interpretations of Augustine's ethics of lying that either fail to attend to developments in Augustine's thought or neglect elements of the Trinitarian interpretation of lying in $D e$

\section{Trinitate.}

In the first analogy between truth in the rational soul and substance in the divine nature, the generation of a true word whose truth is a unity with the thing that is in awareness of the memory is analogous to the generation of the Son whose nature is consubstantial with the Father. The first word to proceed from the rational soul is generated from the awareness of memory such that the same truth is in the awareness of memory and in the thinking attention, just as in the generation of the Word of God from the Father the same substance is in both.

When, therefore, that which is in the knowledge [notitia] is also in a word, then is it a true word, and the truth which is expected from man, so that what is in the knowledge is also in the word, and what is not in the knowledge is not in the word; it is here that we acknowledge the Yes, yes; no, no. In this way the likeness of the made image [i.e. the rational soul] approaches as far as it can the likeness of the born image, in which God the Son is declared to be substantially like the Father in all respects. ${ }^{60}$

The image of God is most like God when producing true words about God and itself in relation to God. True words are those that exhibit truth-content agreement between the knowledge in the memory and the first, pre-linguistic word of intellectual thought.

The "yes, yes; no, no" [est est non non] to which Augustine here appeals for the first time in De Trinitate derives from Mt 5.37. ${ }^{61}$ In De Trinitate, Augustine's interpretation of the "yes, yes; no, no" takes on the distinctively Trinitarian and

${ }^{60}$ Trin. 15.11.20. See Mt 5.37; 2 Cor 1.17; Jas 5.12.

${ }^{61}$ We will examine Augustine's expositions of this verse in several texts in section 3: De s. Dom. mon. 17.51, en. Ps. 5.7, mend. 5.6, 15.28, ep. 82, s. 180, c. mend. 16.33, ench. 5.17, 7.22, Trin. 15.11.20, 15.23. James 5.12 repeats this Matthean account of Jesus's teachings (see s. 180, spec. 46). 
Christological referents that we have already been observing and which are without precedent in his earlier expositions of either Mt 5.37 specifically or lying in general. The first referent of the yes, yes; no, no is the immanent Trinitarian one just observed in which the first yes indexes an analogy between the consubstantial procession of the Son from the Father (qua Word of God) and the unity of truth-content in the generation of the pre-linguistic word from the thing known in the memory.

The Christological sign-assuming "yes, yes; no, no"

The second referent of the yes, yes; no, no of Mt 5.37 in De Trinitate makes use of this analogy to the immanent Trinity but adds the Christological dimension of God's creation through the word of God. Is it here that Augustine takes up the possibility of lying. Just as God made all things through his only-begotten Word-All things were made through him (Jn 1.3) — so too Augustine understands all human action in the world as a voluntary response to that which one knows to be true regarding good works [bene operandi]. The rational soul stores knowledge of good and evil in the memory. All human action begins with the will selecting a sign-assuming word the content of which either truthfully or falsely signifies the rational soul's knowledge regarding good works. The voluntary generation of a true sign-assuming word about good human action is the beginning of a good work. ${ }^{62}$ On the other hand, willfully generating sign-assuming words about good human action that do not derive from the knowledge of good works amounts to sin. The origin of $\sin$ in the rational soul takes place when the will acquiesces to a

\footnotetext{
${ }^{62}$ This work is not good in the sense that natural evil attends it, but in the sense that it results from the agent's limited knowledge of what is true and good.
} 
desire to generate a second, sign-assuming word that does not signify the pre-linguistic word it knows to be the true word regarding its knowledge of good works.

Thus it is not only audible speech and visible gestures intended for communicating ideas that begin with the inner word generated from the awareness in the memory, but every human action. Every human work begins with the generation of a word. Whether a human work is just or sinful, however, depends upon whether the work derives from one's knowledge regarding good works. For every "yes" or "no" in one's knowledge about moral action, the will selects either a true sign-assuming word or it selects a false second word. It is through this true or false second word that one produces righteous or sinful works.

There are no works [opere] of man that are not first uttered in the heart. That is why it is written, The beginning of every work is a word (Sir 37.16). Here too, if it is a true word, it is the beginning of a good work [boni operis]. And a word is true when it is begotten of the knowledge [scientia] of how to work well [bene operandi], so that here too one may apply the Yes, yes; no, no; so that if it is yes in the knowledge by which one ought to live, it should be yes in the word through which one has to work [operandum], and if no, no. Otherwise, such a word will be a lie [mendacium] and not the truth, and from it will come a sin [peccatum], not a right work [opus rectum]. ${ }^{63}$

The beginning of every right work is a true sign-assuming word. The beginning of every sinful action in the world is a prior lie in the rational soul. Every sin has as its precondition a lie, but not every lie generates a sinful work. "We can have a word which is not followed by a work." 64 The reason for this is that like the logos asarkos, the word of the rational soul need not incarnate, it need not be operationalized as a work.

Voluntary consent to a wrongly ordered desire in the human mind generates a

${ }^{63}$ Trin. 15.11.20.

${ }^{64}$ Trin. 15.11.20. 
second word that is not true to the first word in the mind's knowledge regarding not only what is eternally true and good but also what is true and good with respect to moral living in the saeculum — "how to work well" or how "one ought to live." In the inner human, such a word is a lie and a sin, but not yet a work. The mind lies (and sins) the moment it willfully selects a false signifier for this second word. And, through this false word generated by a lie, the rational soul subsequently produces a sinful work as it incarnates or operationalizes through the inner word into the outer, temporal, sensible world. Thus, in two stages a sinful deed results from the will to generate a word in the inner human that is untrue to one's knowledge about good human action and the moral life.

\section{Inseparable operations of the image of God ad extra}

As the Word of God incarnate was not merely eternal Wisdom and Truth but also a human life, so the human mind incarnates through its sign-assuming words that are understood, quite expansively, to include the embodied existence in which one lives and works, whether for good or for ill. As all of God's works ad extra are created through the Word of God that was capable of assuming flesh-All things were made through him [the Word] (Jn 1.3) — so the image of God creates all of its external works through its own sign-assuming words. Here, the immanent, Trinitarian dynamics involved in the generation of the Word of God, the second person of the Trinity, are operative in the economic, historical life of the incarnate Christ. This translation from an immanent Word of God into an economic work is instructive to the rational soul in two senses. Of course, Christ's example of a true, sinless life of good works demonstrates how one ought to 
live. ${ }^{65}$ Here, however, Augustine claims that the reason that the person of the "Word" of God (through whom all things were made) incarnates is that this example shows that the image of God's righteous works ad extra are the outworking, so to speak, of its own previously-generated true and good word.

And the reason why it was not God the Father, not the Holy Spirit, not the Trinity itself, but only the Son who is the Word of God who became flesh, although it was the Trinity that accomplished [faciente] this, is that we might live rightly [recte] by our word following and imitating his example; that is by our having no lie [mendacium] either in the contemplation [contemplatione] or in the work [operatione] of our word. ${ }^{66}$

The incarnation of the Word reveals that our human words ought to be perfectly true in the contemplation of the inner human in order that they might be operationalized as good works in the outer human. For this reason, the image of God ought not generate lies. For, where the will assigns to the sign-assuming word in the inner human a signifier from the memory's knowledge of the truth about good and evil works, the ad extra operations of speech and the moral life incarnate this sign-assuming word of the inner human.

Here, the inseparable operations of the Trinity suggest another sense in which the second, sign-assuming word in the rational soul is like the Trinity creating through the Word who is the Son. Not only were all things made through the Word (Jn 1.3), but all God's works ad extra are indivisible. Likewise, the self-reflexive memory, intellect, and will are inseparably operative in all human action that flows out of the rational soul. Every work of the outer human is indivisibly the work of the entire image of the Trinity in the rational soul, albeit signified sensibly through the word generated in the inner

\footnotetext{
${ }^{65}$ Augustine assumes Christ's life is exemplary in these respects on the grounds of several Scriptures he is fond of quoting, including Jn 14.6, Heb 4.15, and 1 Cor 11.1. ${ }^{66}$ Trin. 15.11.20.
} 
human. Each and every work is righteous or sinful depending upon whether the signassuming word is intended to be true or false in relation to one's pre-linguistic knowledge of good and evil.

Ignorance, Errors, and Lies: Finite knowledge, flawed intellect, and evil will

After exploring the Trinitarian and Christological analogates of the image of God in the pre-linguistic and sign-assuming words in the "yes, yes; no, no" of Mt 5.37, Augustine takes up another collocation of terms with further analogical possibilities. Augustine's fondness for perceiving vestiges of the Trinity in the natural order is evident throughout his writings. ${ }^{67}$ Augustine sees the Trinitarian structure of reality in the created natural world and in its study through the partition of philosophy into natural, rational, and moral. ${ }^{68}$ The rational soul reflects this structure not only in the proper functioning of memory, intellect, and will, but also in the corresponding deficiencies of its fallen state: ignorance, errors, and lies. De Trinitate 15 explores the relationship of God's omniscience, simplicity, and omnipotence in relation to the fallen human's finite knowledge, flawed intellect, and weakness of will.

\section{Ignorance: Creaturely finitude of knowledge}

There is nothing essentially sinful about ignorance. It is a basic feature of human finitude. Human beings are not created to be omniscient. The mind's rational nature was created with a properly functioning intellect integrated with a rightly-ordered will.

${ }^{67}$ See, for example, vera rel. 55.112-13; ep. 11, div. qu. 38; civ. 11.24-28. See also Ayres, Augustine and the Trinity, esp. 63-67, 133-141, 277-281, 317.

${ }^{68}$ civ. 11.25 . 
According to Augustine, in this pre-Fall state, the mind's intellect and will were capable of recognizing truth claims as true, false, or uncertain. ${ }^{69}$

A properly functioning mind would correctly remember and reason about what it had come to know to be true, properly accounting for its ignorance. The first "yes" (or "no") in its knowledge would be followed by a corresponding "yes" (or "no") in its reasoning, and in matters about which the mind was ignorant, lacking knowledge in the memory, there simply would not be a "yes" (or "no"). The things stored in the memory could come to be known either through the consciousness or bodily sensation, with the testimony of others mediating additional knowledge through the latter.

All these things then that the human soul [animus] knows [scit] by perceiving them through itself or through the senses of the body or through the testimony of others, it holds onto where they are stacked away in the treasury of memory. From them is begotten a true word when we utter what we know [scimus], but a word before any sound, before any thought [cogitationem] of sound. For it is then that the word is most like the thing known [notae], and most its image, because the seeing which is thought [cogitationis] springs direct from the seeing which is knowledge [scientia], and it is a word of no language, a true word from a true thing, having nothing from itself [nihil de suo], but everything from that knowledge [scientia] from which it is born. ${ }^{70}$

Prior to the Fall, the human mind knew that it knew all that it knew without error, including those things about which it knew itself to be ignorant. According to Augustine, for those of us who live after the Fall, ignorance remains but increasingly so because we also have to contend with novel problems of falsehood-more specifically, error and lies.

${ }^{69}$ Distinct from error and lying, doubt may be involved in either. Augustine holds that human knowledge is uncertain about most things, even one's own mind is not entirely transparent to oneself. Still, the human can be certain about some things (i.e., that she is alive, that she wants to be happy, that she doubts). See Trin. 15.15.25. See also Drever, Image, Identity, and the Forming of the Augustinian Soul, 124-131.

${ }^{70}$ Trin. 15.13.22. 
Errors: Unknowingly willing false words

Whereas ignorance is a first-order deficiency in knowledge that Augustine associates with the memory, error is a second-order deficiency in knowledge - an intellectual lack of knowledge about the knowledge stored in the memory. Ignorance is a lack of knowing. Error is a mis-knowing; a knowing that mistakenly takes what is true to be false and what is false to be true. Augustine's understanding of ignorance as a deficiency in knowledge makes conceptualizing error to be somewhat tricky.

Although ignorance existed prior to the Fall, there was not yet error in human knowing and thinking - in the memory and the intellect. Even after the Fall, however, it is still the case that human knowledge "must all be true, otherwise it would not be known. No one knows false things except when he knows them to be false. If he knows this, he knows something true, since it is true that they are false." ${ }^{, 71}$ According to Augustine's way of putting things, the false things that one believes to be true (and true things that one believes to be false) are not properly "knowledge" but errors, deficiencies of knowledge. Errors are neither mere ignorance of the sort pre-Fall human beings experienced nor are they sinful in the way lies are. Errors differ from ignorance in that ignorance involves only a lack of knowledge and not necessarily a mistake in one's thinking. An error on the other hand involves the particular ignorance plus the added element of wrongly taking something to be true which is in reality false.

The particular type of falsehood that is an error is a deficiency of true knowledge much as evil is, for Augustine, a deficiency of the good. Evil is a deficiency of the good

${ }^{71}$ Trin. 15.10 .17$. 
and that there is a deficiency in the good can be known, whereas the deficiency itself cannot be known. Likewise, falsehood is a deficiency of the truth and that there is a deficiency in the truth can be known, whereas a falsehood itself cannot be known. Falsehood, like evil, does not exist. Thus errors, or falsehoods mistaken for the truth, are not knowledge according to Augustine. Because only true things can be known, it is possible to know that certain things are false, but it is not possible to have knowledge of something that is false. As knowledge of evil does not exist but ought to be conceptualized as a knowledge that there is a lack of good, so errors ought to be conceptualized as a lack of knowledge about one's knowledge of the truth. Errors, then, are a deficiency in one's thinking about which one is mistaken.

A mind that intends (wills) to express the truth to itself or to another mind regularly errs in doing so because of the intellect's improper functioning that is an effect of inherited sin and sins committed in one's own life. Over time, this improperlyfunctioning intellect inevitably collects and deposits a vast array of erroneous knowledge (yes*) in the storehouse of the mind's memory. When this is the case, false words will be generated for the thinking attention from the storehouse of memory by the will that affirms the agreement between the thing known in the memory (yes*) and its prelinguistic word generated in thinking attention (yes*). The result is an error in memory and thinking attention that, it should be noted, always includes an ignorance of the mistake attendant to such errors. Nothing about this phenomenon yet constitutes a lie. So far we have considered ignorance that pertains to knowledge in the memory and error in the processes of thinking that produces further error and ignorance when thought deposits false knowledge, so to speak, in the memory. 
As was the case with ignorance, God also differs from humanity with regard to error. Whereas the "Yes" of the omniscient Father is simply repeated in the true "Yes" of the eternal Word generated from the Father, in an improperly functioning human intellect, this is not always the case. If the intellect errs in its reasoning, the "yes" in the knowledge of the memory may generate a "yes*" in the thinking attention that contains more or less than the thing known. This "yes*" is then deposited in the memory as erroneous knowledge about which the mind is ignorant. Subsequently, even when the intellect functions properly, the "yes*" of the mis-knowledge in the memory is repeated as a "yes*" in the mis-knowing of thinking attention.

The Trinity does not share this problem. Because of divine consubstantiality and simplicity, God's "Yes" is always "Yes" in God's Word and God's "No" is always "No" in God's Word. These two attributes ensure that there is no falsehood in God.

What is God's knowledge is also his wisdom, and what is his wisdom is also his being or substance, because in the wonderful simplicity of that nature ... being wise is the same as being ... thus [the Son] knows everything the Father knows, but his knowing comes to him from the Father just as his being does. For here knowing and being are one and the same ... Hence it is as though uttering himself that the Father begot the Word ... [The Father] would not have uttered himself completely and perfectly if anything less or more were in his Word than in himself. There supremely we can recognize Yes, yes; no, no. ... And this Word can never have anything false in it because it unchangeably finds itself exactly as he from who it is finds himself. ${ }^{72}$

Although the pre-linguistic human word is "something like that Word of God which is also God, since this one is born of our knowledge as that one was born of the Father's," 73 the human word suffers from falsehood through ignorance and error whereas God's Word

${ }^{72}$ Trin. 15.14.23.

${ }^{73}$ Trin. 15.14.24. 
is always true as a result of divine omniscience. The Father knows all things and the Son knows all things that the Father knows, thus yet again there is no discrepancy in the "yes, yes; no, no" of the immanent Trinity. This is a model of the properly functioning intellect that human beings had in the garden and that will be restored in the resurrected elect. For those in the saeculum, the flawed intellect can undergo healing and renewal but never in this lifetime will it attain perfection.

\section{Lies: Knowing and willing false words}

Due to the mind's created limitations of ignorance in combination with the errors endemic to post-Fall human knowing, the mind generates a great deal of falsehood. And yet it is clear that not every falsehood generated and expressed sensibly constitutes a lie. Sensibly-signified falsehoods may be expressed willingly or unwillingly, and it is primarily this distinction that differentiates errors from lies in one's communication with others. False significations that are errors derive not from a willingness to convey falsehood but from a will that intends to convey truth about which the memory and/or intellect happens to be mistaken. That is, errors are false significations willingly signified but unknowingly false - the signification is willed and known but the falsehood is unknown. Lies on the other hand are false significations performed willingly and knowingly. Thus lying presents as third-order deficiency. Lying is not a deficiency of ignorance or intellect but of will. With respect to the lie, it is irrelevant whether the person actually signifies a falsehood (i.e., with respect to the reality that obtains in the world); all that matters is whether the person intends to signify falsehood (i.e., with respect to what the agent believes to be true). 
In much of Augustine's writings on lying prior to De Trinitate 15, he highlights the "intention to deceive" [voluntate fallendi] as an essential and characteristic element of the lie. ${ }^{74}$ Contra mendacium states in characteristic fashion, "A lie is a false signification told with an intention to deceive" [mendacium est quippe falsa significatio cum voluntate fallendi $].{ }^{75}$ In this and other writings on lying it is precisely the intention of the will to deceive in one's false significations (speech and gestures) that marks the difference between an error and a lie. ${ }^{76}$ Consistently, the second word of the "yes, yes; no, no" applies to the outer human's signification that is either true or false to the first word kept in mind, so to speak, within the inner human (to which Augustine refers variously as the heart $[c o r]$ or mind $[$ mens]). Paradigmatically, the first and second words are construed in terms of thought and speech, respectively, though sensible gestures other than speech are equally signifiers in Augustine's account. Although De Trinitate shares much of this earlier framework, the unprecedented location of not only the first but also the second,

${ }^{74}$ See sol. 9.16, vera rel. 33.61, mend. 3.3-5.5, qu. 6.11, c. mend. 12.26, 14.29, and ench. 7.22 .

${ }^{75}$ c. mend. 12.26 .

${ }^{76}$ Whereas an error is a false signification lacking a will to deceive, a lie is a false signification with a will to deceive. In identifying this distinction, I am in disagreement with Decosimo on the matter of whether the voluntate fallendi refers to a correspondence of mind and speech (see Decosimo, "Just Lies," 663-664) and with Griffiths on the matter of whether the voluntate fallendi is essential to the lie (see Griffiths, Lying, 27-30). This difference of interpretation is made possible in large part by disaggregating the role of the intellect and the will in the definition of the falsa significatio. Decosimo already includes both in the falsa significatio, and so takes the voluntate fallendi to refer to the state of affairs that actually obtains in the world (see "Just Lies," 663). My interpretation departs from Griffiths by disaggregating false signification and duplicitous signification, whereas Griffiths treats them as interchangeable: "Augustine does sometimes use 'false' as shorthand for 'duplicitous"' (Lying, 27). On my reading, duplicitous signification already includes the voluntate fallendi. Like squares and rectangles, all duplicitous significations are false, but not all false significations are duplicitous - for this they must also be intend to deceive. We will return to this issue below in the conclusion. 
sign-assuming word within the inner human, in rational soul, alters Augustine's conception of both the lie and the voluntate fallendi in important and often-overlooked respects that we are now able to consider.

As we have seen, De Trinitate specifies that the first word is generated when the will turns the thinking attention to some thing in the memory that the mind believes to be true. The second word is generated as the will determines what sign will be assumed in order to convey the meaning of the first word. If Augustine were following the pattern of his earlier writings on lying, this is where he would introduce the possibility of the voluntate fallendi. That is, one expects Augustine to use the voluntate fallendi and map the two words such that lying is defined by the will's selection of a false sign to be assumed by the second word with the intention to deceive regarding the first word. However, in De Trinitate, a slight modification is introduced where Augustine asserts only that the second word is intentionally and knowingly false: "When we [lie] we willfully [volentes] and knowingly [scientes] have a false [falsum] word, where the true word is that we are lying." 77 The difference is small but key.

In De Trinitate, the lie takes place in the rational soul itself. Even before a word is vocalized outwardly or otherwise sensibly signified, it is already a lie if the sign assumed for the second word by the will is selected not with an intention to deceive, but knowing that the second word is false in relation to the first word. The lie requires only a false word [falsum verbum] that is analogous to the previous false signification [falsa

\footnotetext{
${ }^{77}$ Trin. 15.15.24.
} 
significatio]. Of course, this false word must be willed, but the fallendi is unnecessary. ${ }^{78}$

The lie requires that the second, sign-assuming word be willfully false, but it is irrelevant whether that false word is intended to deceive. Now, the false word may be generated for any malevolent purpose whatsoever. And, this makes good sense given the way that Augustine explores the image of God and the "yes, yes; no, no" within De Trinitate.

Previously the voluntate fallendi had involved signifying to another in order to deceive this observer such that they unknowingly believe something that the liar believes to be false. In De Trinitate there is no human person immediately present within the rational soul to deceive, and even if the rational soul were self-reflexively its own intended observer, it knowingly generates this false word and thus would not be deceived by it. According to De Trinitate, the rational soul lies when it willingly generates a false word that has no need of a voluntate fallendi insofar as it knowingly generates this false word and no one else is immediately present to be deceived. It might be thought, and not without some warrant, that the rational soul's willing and knowing generation of this false word is an impotent attempt to deceive the Trinity who is more intimately present to the rational soul that it is to itself. ${ }^{79}$ Augustine makes no mention here, however, of any attempts to deceive anyone, whether God, oneself, or others. Of course, Augustine's moral psychology leaves room for interesting possibilities of self-deception—perhaps even deceiving oneself that God does not see what takes place in the pre-linguistic

\footnotetext{
${ }^{78}$ When Griffiths writes that the volunate fallendi is not an essential feature of the lie, he is not referring to the lie that I have described as it is under consideration in Trin. 15, but rather, the construal of the lie in the earlier writings (see Griffiths, Lying, 27-30). That is, he does not recognize the voluntate fallendi as an essential feature for Augustine where the two words are in the inner and outer human respectively, but ceases to be essential when both words are within the inner human.

${ }^{79}$ conf. 3.6.11.
} 
processes of the rational soul. Although this is suggestive of developments along the lines of later Augustinian projects, it does not explain away the fact that Augustine, after numerous writings on lying in which the voluntate fallendi is essential to the definition of the lie, suddenly drops this feature while explicating the lie within the rational soul itself. In fact, and precisely for this reason, something much more pernicious is at work in $D e$ Trinitate's account of lying than in the usual voluntate fallendi.

The lie within the rational soul—willingly and knowingly generating a false signassuming second word about good works - is not one sin among many, or simply the source of all sins of deception, but rather the beginning of every human sin. Having located the origin of sin in a deficient or evil will in De civitate Dei 12.7-9, Augustine now projects that insight back into the rational soul itself. Lacking the voluntate fallendi, this lie in the rational soul is knowingly and willingly generated not so much in order to deceive as it is generated by a rational soul that has already been deceived and participated in the evil of that deception. ${ }^{80}$ Willingly and knowingly generating false words about good works is the source of every sin. It is a recapitulation of the Fall of Adam and of the angels, and thus the reenactment of the founding of the terrena civitas. According to Augustine, the beginning of evil is a lie in the rational soul.

Divine omniscience, simplicity, and omnipotence

Even apart from human sin, the image of the Trinity exhibits disanalogies to the divine nature and attributes by virtue of the Creator-creature distinction. The Trinity is

${ }^{80}$ See civ. 11.13, 14.11, ench. 5.17, Trin. 15.16.26. 
omniscient, ${ }^{81}$ always generates true words due to divine simplicity, ${ }^{82}$ and cannot lie due to its omnipotent will. ${ }^{83}$ In all four stages of the rational soul's existence, the image of God by its very nature reflects these attributes of omniscience, simplicity, and omnipotence through characteristics of its own - its memory, intellect, and will. In its current fallen state in the saeculum, the image of the Trinity is plagued by ignorance, in its ignorance generates erroneous false words, and what is worse, through the weakness of its will, knowingly and willingly generates false words regarding its knowledge of good works through which it operationalizes sin. This has not always been the case nor will it always be the case.

In the pre-fallen state, the rational soul was formed with a finite memory not capable of omniscience and thus exhibiting ignorance. The intellect and will functioned properly and without sin, manifesting the image of God by generating true words through which one's works ad extra of the outer human were performed in the world. When the first human knowingly and willingly, albeit inexplicably, generated a false word about good works in the rational soul, the soul's nature was deformed, the intellect erred, and the memory began to accumulate falsehood. Due to the transmission of this original sin through inherited sin, the human body is mortal, the memory mis-remembers, the intellect errs, and the will is weak. Human being, knowing, and willing diverge.

81 "There is nothing he does not know" (Trin. 15.13.22)

82 "The Son cannot do anything of himself except what he sees the Father doing (Jn 5.19). He is powerfully unable to do this, nor is this weakness, but the strength by which the truth cannot be false" (Trin. 15.14.23). See also Trin. 15.21.40 on the Father's generation of the Son "as a true and not a false Word."

83 "But that Word which is God and is more powerful than us cannot do this. ... And it shows the great power of that Word that he cannot lie [non posse mentiri], because there cannot be there any Yes and no (2 Cor 1.18), but only Yes, yes; no, no (Mt 5.37)" (Trin. 15.15.24). 
The elect who are gifted with the Holy Spirit in the saeculum are gradually being healed of their weakness of will, intellectual failings, and discernment of the knowledge of good and evil. ${ }^{84}$ In this life, the healing process that takes effect by participating in God's love in the Holy Spirit is never complete. ${ }^{85}$ Ignorance in knowledge, error in thought, and weakness of will are constitutive of the human condition in this age. Collectively, the unhealed outer and inner parts of our composite human nature combine to produce erroneous knowledge, ongoing misapprehension of the moral order, and disordered desires. Only in the resurrected life will the rational soul escape error and lies: "when we are like him, when we shall see him as he is ... Then, to be sure, our word will never be false because we shall neither lie nor be in error." ${ }^{86}$ And yet, even in this blessed state, the image of God will not "be equal to God in nature." ${ }^{87}$ It will participate in God's love and immortality and yet not the divine nature. ${ }^{88}$ In this sense, the rational soul is a far cry from the Trinity itself. The divine attributes of omniscience, simplicity, and omnipotence manifest the unity of being, knowing, and willing in the triune God. Thus, three ways in which the image of Trinity fails as an analogy to the Trinity pertain to the memory, understanding, and will: epistemologically, noetically, and morally, the image of God differs from the Trinity, to be sure, but in a manner that points to the Trinity as its

84 "This alone distinguishes between the sons of the eternal kingdom and the sons of eternal perdition. ... Unless therefore the Holy Spirit is imparted to someone to make him a lover of God and neighbor, he cannot transfer from the left hand to the right" (Trin. 15.18.32).

85 "It is God the Holy Spirit proceeding from God who fires man to the love of God and neighbor when he has been given to him, and he himself is love. Man has no capacity to love God except from God" (Trin. 15.17.31).

${ }^{86}$ Trin. 15.16.26.

${ }^{87}$ Trin. 15.16.26.

88 "The nature that has been made is always less than the one that made it" (Trin. 15.16.26). 
source of being, its means of healing, and the one for whom it is created and in whom it finds its happiness.

Exercising the image of God

Augustine considers the implications of the fact that his argument to this point may fail for some readers. They may not recognize the mind within their own rational souls as an image of God, or at least not their own god(s) or the Trinity Augustine worships. They may dispute the numerous vestiges of the Trinity Augustine enumerates; the imago Trinitatis in the memory, intellect, and will of the rational soul; the intricacies of the "yes, yes; no, no" in the processions and in the operations ad extra; or the divine attributes that correspond to features of the natural order, philosophical disciplines, and humanity in its pre-Fall, fallen, regenerate, and eschatological states.

Augustine shoulders part of the blame for this inevitable outcome before reminding his readers what this might mean for their own souls. He repeatedly admonishes the reader to reflection upon this image of God, the mind's memory, intellect, and will, as the key to understanding the Triune God.

As far as we could, we have also used the creation which God made to remind those who ask for reasons in such matters that as far as they can they should perceive his invisible things by understanding them through things that are made, and especially through the rational or intellectual creature which is made to the image of God; so that through this, as a kind of mirror [speculum], as far as they can and if they can, they might perceive the Trinity of God in our memory, understanding, and will. ${ }^{89}$ Augustine has done his best to train his readers to recognize the image of God in themselves: the memory, understanding, and will that comprise the rational soul.

${ }^{89}$ Trin. 15.20.39. 
Augustine has done all that he knows to do, but he also believes that discerning the image of the Trinity in the rational soul is not especially dependent on his own rhetorical devices or on his readers' acumen and efforts to understand.

He knows that not all of his readers will be gifted with God's love, with the Holy Spirit that both enables the soul to recognize itself as an image of the Trinity and empowers the soul to love God and participate in God's nature. Failing to see an image of the Trinity in the rational soul indicates that the Holy Spirit does not inhabit the human, the mind is not (yet) enspirited with God's love.

Those who see their mind insofar as it can be seen, and in it this trinity which I have discussed from many angles as best I could, but do not believe or understand it to be the image of God, see indeed a mirror, but are so far from seeing by the mirror the one who now can only be seen by a mirror, that they do not even know the mirror they see is a mirror, that is to say an image. ... by despising this faith that purifies hearts, what are they doing in understanding the nature of the human mind, in their subtle discussion about it, but condemning themselves on the very evidence of their understanding. ${ }^{90}$

The unregenerate are incapable of discerning that the trinity of the rational soul is the image of God because they lack the gift of the Holy Spirit that empowers the rational soul's capacity to see and love the reflection of God that it is. Their failure to recognize that the rational soul is an image of the Trinity is both an inherited punishment for Adam's sin and an indication, a testimony, that such persons are not regenerate. Only the gift of the Holy Spirit removes this veil of ignorance. The unregenerate remain "wrapped in penal darkness and burdened with a corruptible body that weighs down the soul." ${ }^{, 91}$ In the elect, the Holy Spirit activates or enlivens the capacity inherent in all human nature to

${ }^{90}$ Trin. 15.24 .44$.
${ }^{91}$ Trin. 15.24 .44$. 
know and love God. In this divine activity within the human - God loving Godself through human nature- the elect participate in God. ${ }^{92}$

Augustine offers words of encouragement to those who recognize an image of the Trinity in their own rational soul but who yet have much to learn, to understand, and who continue to find their wills heavily burdened with the concupiscence of the flesh and illicit desires. The transition from darkness to light, conversion, marks the start of a long process of the renewal of the image of God-healing its nature, gaining understanding, and strengthening the will. This process of renewal that takes place in one's earthly existence is gradual. Eventually, it culminates in the transition to a resurrected existence, the state of glory, in which the regenerate believers see for the first time the Trinity who during their earthly existence they only hoped to see.

So the light shines in the darkness, and if as darkness they do not comprehend it, let them first be enlightened by God's gift and become believers [fideles], and begin to be light in comparison with unbelievers [infideles]; and after laying this foundation, let them build themselves up to see the things, which they now believe [credunt] in order that one day they may be able to see them. ${ }^{93}$

The foundation of faith described here is laid in one's conversion to faith in Christ through the enlightening work of the Holy Spirit. After becoming a believer, the subsequent building upon this foundation is the work of the person who now believes, but in concert with the Holy Spirit's ongoing work of renewal, healing her nature by making her wise through participation in the divine nature, Wisdom itself. As this healing takes place, the rational soul rightly orders its loves. Taking God as the object of its contemplation, the image of God is renewed in true righteousness and holiness. Because

${ }^{92}$ See Trin. 15.3.5; 14.4.6; 14.8.11; 14.12.15.

${ }^{93}$ Trin. 15.27.49. 
God is ineffable, invisible, and immaterial, God gives to the human mind itself - its

nature and perceptual operations — as an object for reflection. This self-reflexive perception is the activity by which the mind enacts and perceives itself as an image of God's triune being and processions.

Among all things created by God, none is more profitable as an object of reflection for understanding God's ineffable, immutable, incorporeal nature than the rational soul that is the image of the invisible God.

But as far as concerns that supreme, inexpressible, incorporeal, and unchangeable nature and the perception of it in some measure or other by the intellect, there is nothing on which the human mind could better practice [exerceat] its gaze (provided of course that it is governed by the rule of faith) than on that which man has in his nature that is better than other animals, better even than the other parts of his own soul, and this is the mind [mens] to which has been allocated a kind of power to see invisible things, and to which the senses of the body also bring all things for judgment as it presides, so to speak, in the innermost and uppermost place of honor, and which has nothing above it to whose government it is subject except God. ${ }^{94}$

Because the mind is unmatched as a site for reflection upon the Trinity, Augustine expends considerable time and effort in arguing for and urging the reader toward its contemplation. Indeed, this is what the image of God is for. It is made in order to know itself as the image of its Creator and in this knowing to reflect back to the Trinity the praise God is due.

Augustine concludes the exercise through which De Trinitate guides the Christian reader with two final movements that both perform and script, in a sense, two trinities of the inner human. First, in the penultimate movement, Augustine turns his address from outward to inward, from the reader to his own rational soul. Then, in his closing

${ }^{94}$ Trin. 15.27.49. 
doxological discourse, Augustine reorients his address yet again from inward to upward, from the image of the Trinity to the Trinity itself.

Writing to his own rational soul, Augustine calls the soul to contemplate the gracious God who forgave its sin in regeneration and continues to heal and renew his nature. ${ }^{95}$ Augustine recognizes and confesses the soul's weakness of will, the lack of clarity with which the understanding sees, and the turbulence of the soul's preeschatological existence that inhibits its ability to persist in contemplation of things eternal.

Lift up your eyes to that light and fix them on that if you can. Thus you will see how the birth of the Word of God differs from the procession of the gift of God which is the reason why the only-begotten Son said that the Holy Spirit proceeds from the Father, not that he is begotten of him. ... But you are unable to fix your gaze there in order to observe [cernendum] thus clearly and distinctly. You cannot do it, I know [scio]. I am telling the truth, I am telling it to myself, I know [scio] what I cannot do. However, this same light has shown you those three things in yourself, in which you can recognize [agnosceres] yourself as the image of that supreme trinity on which you are not yet capable of fixing your eyes in contemplation [contemplari]. It has shown you that there is a true word in you when it is begotten of your knowledge [scientia], that is when we utter what we know [scimus], even if we do not think [cogitemus] or speak a meaningful sound in that language of any people; provided our thought [cogitatio] is formed from what we know [novimus], and the image in thinking attention [cogitantis] is completely like the awareness [cognitionis] which was already contained in the memory, with will or love as the third element joining these two together as parent and offspring. That this will proceeds from awareness [cognitione] - for no one wants anything if he is totally unaware [nescit] of what it is, or what sort of thing it is - and yet that it is not itself an image of awareness [cognitionis], and that thus in this intelligible [intelligibile] case there is suggested a certain difference between birth and procession, because to observe by thought [cogitatione] is not the same thing as to desire or even to enjoy by will; that all

\footnotetext{
${ }^{95}$ He writes, "But you, O my soul, among all these things that I have said about that supreme trinity ... where do you perceive that you are among all these things, where do you lie or where do you stand until all your sicknesses are healed by him who has shown himself gracious to all your iniquities" (Trin. 15.27.50).
} 
this is so, let him note [cernit] and discern who can. ${ }^{96}$

In this passage, the notion of the image has two distinct referents: the rational soul as an image of the Trinity ("you [rational soul] can recognize yourself as the image of that supreme trinity on which you are not yet capable of fixing your eyes in contemplation") and the word generated from the memory as an image of the awareness ("our thought is formed from what we know, and the image in thinking attention is completely like the awareness which was already contained in the memory"). Augustine's overall concern is to show the difference between the mode of origination of the mental word - the image in the thinking attention [cogitatio] of the awareness [cognitatio] in the mind's memoryfrom the mode of origination of the will that binds the true word (in thought or cogitation) and the thing known (in the awareness or cognition of memory). Both the true word and the will proceed from the awareness of the thing known in the memory. But, whereas the true word is an image of the thing known — being generated from the thing known - the will differs in that it constitutes the bond between the generated image and the thing known. The will proceeds from the awareness but in a mode of loving desire rather than in a mode of knowing. And, unlike the word, the will is not an image generated from the awareness. Thus the human mind suggests how it is that the eternal processions of the Son and the Holy Spirit differ from one another.

This distinction between the generation of a word and the procession of the will in the rational soul, in the image of God, finally provides Augustine and his readers with the analogue through which to contemplate the distinction between the Son's generation and the Spirit's procession in the Holy Trinity itself. In this distinction between the word's

96 Trin. 15.27.50. 
generation and the will's procession, the rational soul is able to contemplate the

Trinitarian distinction between the modes of origination of the divine persons - the generation of the Son and the procession of the Spirit. The true Word of God (Son) proceeds as an image generated from Truth itself (Father) whereas the Gift of God (Holy Spirit) proceeds from the Father and Son as the loving desire that binds them as one.

Two distinct referents of "image" are always involved in this scheme. Every time the rational soul (qua imago Trinitatis) thinks, it imitates the processions of the Trinity as the first word generated is an image of the awareness in the memory with the will as the bond of agreement between the two. Furthermore, we can see how these two senses of image (qua rational soul and qua word generated from the awareness of the memory) might coincide. Where the word that is generated from the memory is precisely the rational soul itself, then two images occur identically. The rational soul thinking itself, turning its attention to itself as its own object of thought, brings the two senses of image into a concursus. The image of God generates out of the storehouse of its memory a true image of itself when it thinks itself. Furthermore, because, like the Trinity, the operations of the image of the Trinity are indivisible ad extra, the entire rational soul is always operative in the generation of words that are the object of the mind's thinking attention.

What this means is that even when and where the rational soul is not the conscious object of its own thinking attention, there remains a non-conscious unified operation of the memory, intellect, and will that serves not merely as a condition of possibility for the generation of other words in thought and desire, but which also is very much present in its operations of thinking and desiring themselves. Thus, when Augustine finally narrates the rational soul's turning its attention from the rational soul 
itself to the Triune God of which it is an image, both senses of "image" remain operative - the rational soul remembers, knows, and loves itself in its remembering, knowing, and loving God. It is then that the "yes, yes; no, no" in the rational soul is spoken as a pre-linguistic word analogous to the generation of the Word from the Father in the love of the Spirit. It is then that the Delphic oracle is fulfilled—when the mind rightly knows itself in its true knowledge of God. 


\section{II.3 Retracing Augustine's ethics of lying}

Much ink has been spilled detailing Augustine's position on lying. The basic elements of his ethic are these: 1) A lie is a false signification [falsa significatio] with an intention to deceive [voluntate fallendi]. ${ }^{97}$ 2) All lying is a sin and thus absolutely prohibited. Lies cannot be justified, no exceptions. ${ }^{98}$ 3) Scripture might seem to condone lies. It does not. ${ }^{99}$ 4) A just cause, loving motivation, good intention, or the avoidance of horrendous consequences might seem to justify lying. They do not. ${ }^{100}$ 5) Some lies are worse than others. No one may be acquitted of a lie they have told, though they may be pardoned. ${ }^{101}$ More culpable lies require greater punishment or penance for their pardon. All of this is standard fare in scholarship on Augustine's ethics of lying, and all of it is correct. At least to a point.

Pick up nearly any article or book addressing Augustine on lying and these features will be either taken for granted or prominent among the elements addressed in praise or critique. Augustine's most careful interpreter on the topic of lying, Paul Griffiths, addresses each of these standard elements in his reading of Augustine's ethic of lying. ${ }^{102}$ Whether a given author affirms or contests the validity of Augustine's position on lying or seeks to challenge this interpretation, these basic elements are an established

\footnotetext{
${ }^{97}$ See $c$. mend. 12.26. See also mend. 3.1, ench. 7.22.

${ }^{98}$ See mend. 18.37, ench. 6.18, 7.22.

${ }^{99}$ See ep. 28, mend. 15.26-18.39, ep. 82, c. mend. 10.25-17.36.

${ }^{100}$ See $c$. mend. 7.17-10.24, ench. 7.22.

${ }^{101}$ See en. Ps. 5.7, mend. 13.23-14.25, c. mend. 8.19, 15.31-17.35, ep. 82.22, ench. 7.22.

${ }^{102}$ Griffiths offers largely affirmative evaluations of these elements. He details important nuances in both constitutive features of the lie. See Paul J. Griffiths, Lying, 25-39.
} 
scholarly consensus. ${ }^{103}$ And rightly so. Each is affirmed numerous times by Augustine in various contexts. ${ }^{104}$

Of course, minority opinions do crop up from time to time contesting these five well-established elements. Here, I am not referring to those who contest the validity of this ethic of lying but those who contest the majority interpretation of Augustine either on one of the major points above or some of the finer details of his definition of lying, scriptural exegesis, or the logic of his argumentation. Some of these critical engagements make quite compelling arguments that draw largely upon Augustine's own writings to advance sweeping reconsiderations of what exactly Augustine's ethic of lying entails. In what follows I show why it is that quite often interpretations of Augustine on lying that are incompatible with the above features can also be legitimately argued as representing Augustine's ethic of lying. For example, there is some warrant for Decosimo's thesis that "Augustine is not best understood as forbidding lying absolutely ... he would permit and

${ }^{103}$ See, for example, Brinton, "St. Augustine and the Problem of Deception in Religious Persuasion;" Boniface Ramsey, "Two Traditions on Lying and Deception in the Ancient Church," The Thomist 49:4 (1985): 504-533; Feehan, "Augustine on Lying and Deception," Augustinian Studies 19 (1988): 131-139; Feehan, "The Morality of Lying in Saint Augustine," Augustinian Studies 21 (1990): 67-81; Feehan, “Augustine’s Own Examples of Lying," Augustinian Studies 22 (1991): 165-190; Julie A. Fleming, "The Helpful Lie: The Moral Reasoning of Augustine and John Cassian," Ph.D. dissertation, Catholic University of America (1993); Dodaro, "Eloquent Lies, Just Wars and the Politics of Persuasion;" Glen Newey, "Political Lying: A Defense," Public Affairs Quarterly 11:2 (1997): 93-116; Paul J. Griffiths, "The Gift and the Lie: Augustine on Lying," Communio: International Catholic Review 26 (1999): 5-30; von Heyking, Augustine and Politics; Weaver, "Unjust Lies, Just Wars?;” G. Scott Davis, "A Vindication of Theology: A Response to Alain Epp Weaver," Journal of Religious Ethics 29:1 (2001): 79-85; Johnson, "Can a Pacifist Have a Conversation with Augustine?;" Griffiths, Lying; Christopher Levenick, "Exceptis Igitur Iocis: Augustine on Lying, Joking, and Jesting," Augustinian Studies 35:2 (2004): 301-323; Decosimo, "Just Lies;" Remo Gramigna, "Augustine on lying: A theoretical framework for the study of types of falsehood," Sign Systems Studies 41:4 (2013): 446-487.

${ }^{104}$ Though, as we will see, his earlier writings allow for more expansive concessions. 
require lying in certain circumstances," $" 105$ as there is for von Heyking's claim that "Lying is not only permissible in certain circumstances, but also required." ${ }^{\prime 106}$ These revisionists are not mistaken in discovering elements within Augustine's thought that push him in a direction other than the standard, what we might call "canonical," reading. The relevant interpretive question, however, is whether the warrants for their readings are stronger than those of other methods of reading Augustine on the topic of lying.

The traditional reading is "canonical" not only in constituting a historical consensus, but also in terms of its method. That is, the vast majority of scholars (including Griffiths, Decosimo, and von Heyking) read the major writings on lying throughout Augustine's career as if they present a coherent whole-as if apparent discrepancies can be ironed out, so to speak, by appeal to other texts, categories, and audiences. This sort of canonical reading implies, without justifying the assumption, that we can discern what Augustine "meant" to conclude regarding a particular case presented, for example, in De mendacio 4 by reading what he says about an allegedly analogous case in De diversus quaesionibus $83 .{ }^{107}$ Perhaps we may even interpret the entirety of Augustine's writings on lying in light of a public/private distinction voiced by Evodius in De libero arbitrio to differentiate between species of killing. ${ }^{108}$ In making these argumentative moves, von Heyking and Decosimo read Augustine canonically, though their canonical methods differ, using selected texts and categories as the lenses through which to read other texts and categories. Scholars do recognize that Augustine

\footnotetext{
${ }^{105}$ Decosimo, “Just Lies,” 662.

${ }^{106}$ von Heyking, Augustine and Politics, 118.

${ }^{107}$ See von Heyking, Augustine and Politics, 119.

${ }^{108}$ See Decosimo, "Just Lies," 666, n.15.
} 
adds elements in his later writings not present in the earlier ones. ${ }^{109}$ But, the question scholars consistently put to Augustine and attempt to answer, "What was his ethic of lying?" already implies a canonical approach. The presumption is that Augustine offers one ethic of lying across his corpus. Because, as demonstrated in Part I, Augustine's thought does develop over time, including between his two major treatises on lying-De mendacio (395) and Contra mendacium (420) — canonical readings predictably generate both standard and revisionist readings of Augustine on lying. And, both (canonical) readings risk ironing out wrinkles that a more historicized reading leaves intact.

I argue that Augustine's ethic of lying develops over time. In this respect, it is like his account of the image of God (and, as we have seen, the male-female relationship signified by it). In important ways his ethic develops in parallel to his theological anthropology. In this sense Paul Griffiths is correct - the image of God is integral to Augustine's ethic of lying such that Augustine's ethic "require(s) assent to a large number of truths about God's nature and the image of God in us, for Augustine thinks that what he argues about the lie presupposes the truth of such Christian convictions."110 What I want to add to and modify of Griffiths' account is the manner in which the image of God helpfully illuminates the ways in which Augustine's ethic of lying changes over time. The image of God is integral to Augustine's ethic of lying. And yet, this claim is not borne out either by a survey of the secondary literature on Augustine's ethics of lying or by reading Augustine's six significant texts on lying prior to De Trinitate. A major reason for this is that the image of God is never mentioned by Augustine in the vast

\footnotetext{
${ }^{109}$ c. mend. 7.18 is often the example given.
}

${ }^{110}$ Griffiths, Lying, 15. 
majority of his discussions of lying — not in De mendacio or Contra mendacium, letters (Epistulae 28, 40, 73, 82), expositions of the Sermon on the Mount or the Psalms (5 and 14), or in his Enchiridion (6-7). Not until De Trinitate 15, after the lion's share of his writings on lying, does Augustine explicate what Griffiths takes to be essential. That is, the ethics of lying and the account of the image of God develop largely in parallel up until their quite late convergence in De Trinitate 15 . And yet, rarely do scholars turn to De Trinitate 15 as an important text for interpreting Augustine's ethics, and almost never for lying in particular.

Using a more historical rather than canonical hermeneutic, I show that features of Augustine's ethics alter over time in ways analogous to his conception of the image of God. When recognized, these developments help arbitrate disputes about Augustine's ethics in general and his ethics of lying in particular. Some interpretations of Augustine's "ethic of lying" (as if it were static) prove to be more commensurate with Augustine's moral reasoning in one period than they are with his thought during another. With the vision of lying in De Trinitate 15 discussed above, we will have the benefit of hindsight from which to understand and appreciate how earlier writings develop in light of later ones. One of the consequences of this approach is that the very question, "What is Augustine's ethic of lying?" is disclosed as entailing a "canonical" a priori-namely, that there is one ethic of lying in Augustine's writings that is "there" waiting to be discovered and explained. By way of contrast, the question, "How does Augustine's ethic of lying develop over time?" has the advantage of allowing for a single ethic, if that is what is discovered, without imposing a method that inadvertently flattens out important differences and distinctions that emerge and evolve in Augustine's thinking over time. 
It would be possible to do with Augustine's ethic of lying much as I have with his concept of the image of God. That is, one could trace the logic operative in his ethic as it develops across his writings, seeking to tease out all of the various facets, tracking the scriptures that become central or remain tangential to his reasoning, and through this investigation to examine how it is that he arrives at his final ethic of lying. The task at hand is considerably less arduous, however, given our more limited purpose of demonstrating the difference the image of God makes to Augustine's ethics.

Indeed, we arrived at lying as the ethical issue of relevance for this study only (and precisely) because of the manner in which Augustine locates it as integral to the image of God at the end of De Trinitate. Furthermore, the study of the image of God, to this point, has already identified a particular feature of Augustine's ethic of lying that is more than sufficient to disclose how it is that his understanding of this issue develops over time. For, in De Trinitate 15, the final major engagement offered by Augustine on the ethics of lying, the central scriptural motif with which he operates is, again, the "yes, yes; no, no" of Mt 5.37 .

As it turns out, there is no better candidate than Augustine's use of Mt 5.37 for the work of discerning the difference the image of God makes to Augustine's ethic of lying. Of the more than 100 scriptural texts that Augustine cites in his six expositions of lying (including four shorter discussions and the two major treatises De mendacio and Contra mendacio), one stands out as the sole verse that is a staple across both Augustine's early and late writings — namely, Mt 5.37. ${ }^{111}$ For this reason, its gradual reinterpretation offers a vantage from which to appreciate developments in Augustine's ethics of lying over

${ }^{111}$ See Appendices C and D. 
time. Taking up Mt 5.37 as a red thread that runs through Augustine's writings, we do not restrict ourselves only to the half dozen or so texts usually consulted for Augustine's ethic of lying, but open up possibilities as he appeals to the "yes, yes; no, no" nearly thirty times across seventeen texts from around 390 to 426. Just as Augustine's interpretations of scriptural texts change as his understanding of the image of God develops, so also Augustine's expositions of Mt 5.37 take at least three forms and appear quite different in De Trinitate than they had previously.

More than half of Augustine's invocations of Mt 5.37-But let your speech be, 'Yes, yes; no, no.' Anything beyond this comes from evil ${ }^{112}$ occur in eight writings from the years 392-397. These writings derive two distinct but related moral norms from the verse — an absolute norm prohibiting lying and a prima facie norm against swearing oaths. Six texts-Epistula 23, De diversis quaestionibus octoginta tribus 53, Enarrationes in Psalmos 5 and 14, De mendacio, and De agone Christiano-interpret Mt 5.37 as a prohibition of lying. The other two texts_Expositio ad Galatas and De Sermone Domini in Monte-exposit Mt 5.37 in terms of the morality of swearing. The former expositions focus on the "yes, yes; no, no" clause whereas the latter attend to the context of the verse within Mt 5.33-37 where Jesus teaches his disciples not to swear.

Escaping deception and attaining perfection in steps and stages

At least three different texts that are difficult to date are candidates for having been Augustine's first citations of Mt 5.37-De diversis quaestionibus octoginta tribus 53 (388-395), Epistula 23 (392-394), and Enarrationes in Psalmos 14 (392-395). We will

${ }^{112}$ Sit in ore vestro est est non non et quidquid amplius est, a malo est (en. Ps. 5.7). 
examine them in the order of their instructiveness where Mt 5.37 is concerned. Although Augustine does not (explicitly) appeal to the image of God as a basis for his ethic of lying in these texts, collectively they suggest that Augustine's early account of lying comports with the main features and framework in the contemporaneous account of the image of God.

Epistula 23 records Augustine's diplomatic response to a Donatist bishop, Maximinus, who Augustine has recently learned has re-baptized a Catholic parishioner whose previous baptism had been in a non-Donatist Catholic church. In his letter, Augustine alludes to the "yes, yes; no, no" when assuring Maximinus that Augustine recognizes his high honor in the order and law of nature, though this honor is by virtue of his creation to the image and likeness of God and not his episcopal office.

Augustine explains that he wants his greeting to Maximinus to be received as neither sarcastic nor sycophantic. He includes Mt 5.37 as an indication that when he addresses the Donatist bishop, "To my most beloved lord and honorable brother, Maximinus, Augustine, a priest of the Catholic Church sends greetings in the Lord," that he is sincere.

But as for "honorable," which I also added, I did not add this to honor your episcopacy. After all, you are not my bishop, nor should you take this with contempt, but that spirit by which we ought to have on our lips, Yes, yes; no, no. For you are not unaware, nor is any human being who knows us unaware, that you are not my bishop and that I am not your priest. ${ }^{113}$

Augustine assumes a familiarity with the meaning of the scriptural "yes, yes; no, no" on Maximinus's part for which Augustine provides no interpretation here. He will go to great lengths to explicate its meaning elsewhere, as we will see. Augustine evidently

113 ep. 23.1 
takes this verse to convey truthfulness, or at least a spirit contrary to "contempt" and an indication of Augustine's appreciation for Maximinus's "honor."

Augustine explains whence the honor that he accords to Maximinus derives and invites Maximinus into a deeper understanding of the matters at hand. He tells him that the honor that is his is one that can be lost or diminished if Maximinus fails to comprehend that which he ought. Maximinus's honor is that of a human being who has been made "to the image and likeness of God." God placed the human in a position of honor within the natural order, but it is a position that is preserved by the proper use of one's intellect.

I, therefore, am willing call you "honorable" on the basis of that rule by which I know that you are a human being and know that a human being has been made to the image and likeness of God and placed in a position of honor by the very order and law of nature [ordine et iure naturae], if by understanding [intellegendo] what he should understand [intellegenda] he preserves [seruet] his honor. ${ }^{114}$

Augustine provides little in the way of an explanation here, but we know from his $D e$

Genesi ad litteram imperfectum and De sermone Domini in monte that the chief purpose of the intellect, as he understands it at this early date, is to submit to God's dominion and orient one's love toward the image and likeness of God who is God's Son, the very form of Wisdom itself. At the same time, the intellect, in obedience to God, ought to exercise dominion over all natures lower than itself (i.e., all natures other than God, since it is the highest other than God's nature), putting to death the sinful, concupiscent desires of the flesh, rightly ordering them in accordance with the place that the objects of its love have in the natural order.

${ }^{114}$ ep. 23.1 
A second early citation of Mt 5.37 in Augustine's corpus is De diversis quaestionibus octoginta tribus 53 (388-395). Like Epistula 23, his response to a question about the Israelites' plundering of the Egyptians interprets Mt 5.37 in terms of lying rather than swearing. Unlike Epistula 23, it does not refer to the image of God, and yet it too evidences how Augustine's understanding of the image of God at this time suggests the framework in which Augustine understands his ethics of lying to operate, including the "yes, yes; no, no."

Augustine's two allusions to Mt. 5.37 in De diversis quaestionibus octoginta tribus 53 wrestle with the Israelites' deception and how this might be reconciled with the teaching of Jesus in Mt 5.37. He argues that "as far as deceit in concerned, the highest and perfect virtue is to deceive no one and to be an example of what has been said, "Let this be in your mouth: 'yes, yes; no, no.",115 Augustine observes that this command is given by Jesus to his followers as an instruction not to deceive, to be sure, yet it is also a counsel of perfection and thus one should attend to the steps by which "one may arrive at the height of perfection." 116 On the path that leads from the ultimate vice of regular deception to the highest virtue of deceiving no one, "there is a step, to be sure, which is to deceive no one who is a friend or stranger, but occasionally, nonetheless, to deceive an enemy." ${ }^{117}$ It is at this early stage on the path to moral perfection that the reader finds the Israelites used of God to plunder and punish the Egyptians in a manner appropriate to their virtues and vices of verity and deception at that time.

\footnotetext{
115 div. qu. 53.1.

116 div. qu. 53.1.

117 div. qu. 53.1.
} 
God knows not only who is deserving of deception and punishment, and who is "unjustly deceived," but also who has attained to which stages in the virtue of truthfulness and the mortification of the vice of deceitfulness. ${ }^{118}$ God knows who can, with justice, be called upon to exercise which stages of the particular virtuous capabilities that they have cultivated.

Yet, as he distributes their deserts to those who deserve them, because this also pertains to justice and truth, he makes use of souls for the merits and deserts that are appropriate to their steps [of virtue], so that, if someone deserves to be deceived, not only does he not deceive him by himself but neither does he deceive him by the type of person who sufficiently loves and consistently observes [the words], Let this be in your mouth; yes, yes and no, no, nor by an angel, for whom the role of deception is out of character, but either by the type of person who has not yet stripped himself of inclinations of this sort or by the type of angel who, on the lowest rungs of nature because of the perversity of his will, has been set aside either to punish sins or to discipline and purify those who are being reborn according to God. ${ }^{119}$

Augustine offers two analogies from his everyday affairs to show how fitting it is that God remain aloof in God's role-specific perfection and not engage in the sort of direct actions that would "dirty" God's hands in the vicious act of deception and plundering that he delegates to the slowly-perfecting Israelites. The two analogies involve 1) a judge delegating executions that are below his dignity to an executioner whose "cruel temperament" is more fitting for the task, and 2) a person retaining a dog for the purpose of biting a thief. In both cases a task that is less than fitting to a person's office or role

118 div. qu. 53.1. My reading differs from that of Decosimo who suggests "even someone of the utmost virtue can and does righteously deceive the enemy by God's permission and command" ("Just Lies," 679-680). What Augustine actually affirms here is that those of the utmost virtue never lie. Only those deficient in virtue lie. Even then they are not praised for lying or commanded to lie, but used of God in a manner fitting to their deficiency and as appropriate for God's purposes.

${ }^{119}$ div. qu. 53.2. 
must be assigned to another whose disposition or nature makes for a more fitting performance of the function. Regarding the executioner, we are told that "his temperament has been appointed for the task of killing," and the master assigns the dog its task "because of its nature." ${ }^{\prime 20}$ It would be beneath a judge, bureaucrat, or lawyer to perform the just execution, Augustine explains, just as it is beneath a household member or even a slave to bite the justly-bitten thief.

Augustine develops these analogies in order to persuade or instruct the reader that because it would be inappropriate for God to deceive, God sovereignly and providentially makes use of those suited to God's just purposes. Although he does not mention the image of God explicitly in making this argument as he had when discussing honor in Epistula 23, he does make a similar, implicit reference to it in a quite rare explicit reference to the naturalis lex in his corpus.

From this ineffable and sublime arrangement of affairs, then, which is accomplished by divine providence, a natural law (naturalis lex) is, so to speak, inscribed upon the rational soul, so that in the very living out of this life and in their earthly activities people might hold to the tenor of such dispensations. $^{121}$

Augustine expects his use of analogies to an executioner and guard dog in his arguments to be persuasive due to the natural law that human beings have inscribed in their rational souls. The natural law in the rational soul should convince the reader that an executioner's disposition and a guard dog's nature are analogous to the Israelites' stage in their moral development - it was fitting for them to fulfill the role of deceiving and

${ }^{120}$ div. qu. 53.2

${ }^{121}$ div. qu. 53.2. 
plundering the Egyptians even though (and precisely because) deception of this sort is prohibited to the perfectly virtuous.

On these terms, the Israelite's deception and plundering of the Egyptians is capable of being praised within Scripture and by Scripture's subsequent readers, not because their deception was not sinful, but because they exercised the virtues that they had attained at this early stage in the moral development of God's people throughout history. Their case differs from the two analogates in that their fittingness to be agents of God's just dealings was not determined by their temperament or nature. Rather, it was their virtue or lack thereof - they were in an "earlier age of the human race" when humanity was in the dispensation of the old covenant under the guardianship of the law (Gal 3.24). It is not at all difficult to explain then, and is exactly what one should expect, that although the Israelites are celebrated for their deceptive plundering of the Egyptians, the perfection enjoined by the "yes, yes; no, no" comes in the context of a new dispensation, in a later covenant. This later command is disclosed by a teacher [magistro] to those who are "older" in the maturation of virtue and in the history of humanity, to those who are prepared to hear it, to those for whom it is fitting.

What took place, then, in those persons according to their steps we recognize in the whole human race-that in keeping with the times, some things were enjoined chiefly upon a spiritual people. It is not surprising, then, if those who were still worthy of deceiving an enemy were commanded to deceive an enemy who was worthy of being deceived. For they were not yet fit to be counted among those to whom it was said, Love your enemies (Mt 5.44), but were such as those to whom it was only required to be said, You shall love your neighbor and hate your enemy (Mt 5.43). ${ }^{122}$

122 div. qu. 53.3. 
Augustine clearly does not consider the Israelites to have progressed very far in their moral development. But given his faith in moral progress across human history as well as the potential for the growth in virtue in the life of the individual, at least in this early stage of his own development, Augustine finds it worthwhile to praise small steps commensurate with one's present capabilities.

This commendation of small steps and also the means of individual progress toward perfection are evident in numerous other texts from this period, including Augustine's exposition of Ps. 14 (c. 392-395). Here he contrasts "small-scale acts" appropriate to beginners with the "great achievements" that are attainable by those who have progressed to attain "the qualities of the perfect."123 Among the qualities of the perfect, he includes those who are able "to press the truth outwardly just as it is in their hearts, to have on their lips Yes, yes; no, no." Those who are faithful in the small matters "will proceed to those greater things in which powerful and unshakable stability may be gained." 124 And, as in his discussions of the image of God from this period, Augustine cautions against any disposition other than orienting one's rational soul toward God, the greatest good: "The righteous one knows without a shadow of a doubt that there is no such thing as a spiteful person except when the mind turns away from the eternal changeless beauty of its Creator toward the beauty of the creature which was made out of nothing." 125 The ascent through the numerous steps in moral progress occurs only as one fixes one's attention on the Son through whom all things were made.

\footnotetext{
123 en. Ps. $14.4,5$.

124 en. Ps. 14.5.

125 en. Ps. 14.4.
} 
Of course, the vision outlined in these texts comports with what we observed of De Genesi adversus Manicheos 1.23.35-41, and De sermone Domini in monte 2.9-3.12 regarding the seven ages (in which the these Israelites would have been in the third age) and eight beatitudes construed as a progression in moral progress. As we saw there, the incarnation and refashioning of the image of God does not occur until the sixth age or step in moral progress. And, as we have seen, a few years later his expositions of Romans would present an alternative four-stage framework that would, for all intents and purposes, come to replace the earlier framework. Even in this first account of four stages, however, these Israelites would still have been in the first stage, as the transition to the second stage, according to Augustine, arrives with Moses's reception of the law that the Israelites who plundered Egypt did not yet have. ${ }^{126}$

We observed in Part I.1-I.4 that during the years when the texts currently under consideration were composed, Augustine understood the Son of God and not the human being as such to be the image of God. We also saw that the human being approaches God in a gradual progression by orienting one's love toward the Son who is the image and likeness of God. By loving God, directing one’s desires to the greatest good, human beings are renewed and become more like the image of God who is God's likeness itself. Although the image of God does not bear directly upon the meaning of the "yes, yes; no, no" at this point in Augustine's writings, as will become the case in De Trinitate 15, these very early works provide useful indications of Augustine's early conception of the image

\footnotetext{
${ }^{126}$ This proposal would be revised later when the transition to the second stage is portrayed as occurring in the "Fall" that Augustine perceives in Gen 3.
} 
of God and how it maps onto his expositions of lying - and, as we will see, oath swearing - even when the image of God is not mentioned.

Mt 5.37 and the ethics of swearing

A pair of texts from 394 exposit Mt 5.37 in relation to the question of swearing and manifest slightly different features of Augustine's moral reasoning than do the above analyses of lying. In De sermone Domini in monte and Expositio epistulae ad Galatas Augustine examines Mt 5.37 within the context of Jesus' discourse about swearing from Mt 5.33-37. This discourse locates the "yes, yes; no, no" that is so important to Augustine in relation to the prohibitions of swearing in the Hebrew Bible. ${ }^{127}$

Again, you have heard that it was said to the ancients, "You shall not swear falsely [periurabis], but fulfill your oath to the Lord." But I tell you not to swear [iurare] at all: neither by heaven, for it is the throne of God; nor by the earth, for it is the footstool of God's feet; nor by Jerusalem, for it is the city of the great King. And you shall not swear [iurabis] either by your head, for it is not in your power to make one hair of it white of black. But let your speech be, "Yes, yes; no, no." And whatever is over and above this is from evil. ${ }^{128}$

Augustine immediately deduces that Jesus is not claiming that swearing as such is a sin, given the numerous times that he takes Paul to be swearing (Rom 1.9, 1 Cor 15.31, 2 Cor 11.31, Gal 1.20). Augustine assumes that Paul would have known and correctly interpreted Jesus' teaching and concludes that oaths are not being forbidden by Christ. “The Lord's prohibition of swearing [iuretur] is to be understood, therefore, as meaning that one is not to desire an oath as if it were something good, lest - through a habit engendered by the constant repetition of swearing [iurandi] — he gradually descend to

${ }^{127}$ See Lev 19.12; Nu 30.2; Dt 23.21.

${ }^{128}$ Mt. 5.33-37. See s. Dom. mon. 17.51 and s. 180.1. 
false swearing [periurare]. ${ }^{, 129}$ According to Augustine, Jesus is cautioning against the habit of swearing, due to the susceptibility to swearing falsely of the person who swears habitually. That is, Mt 5.37 does not prohibit swearing as it does lying, but warns against cultivating a habit of swearing that might lead to false swearing.

For what reason might oaths justifiably be utilized in this reading of "Let your speech be 'Yes, yes; no, no.'"? Oaths are at times necessary due to the sinfulness of the interlocutors one is trying to persuade of the truth, where one has a good reason for them knowing this truth. Swearing is neither an evil in itself nor a good, but "one of the things that are necessary." "130 Swearing is condoned where the "good use [bene uteris] of an oath which, although it is not a good thing, is nevertheless necessary to persuade someone to believe what you are trying to induce him to believe for a good purpose [utiliter]." Thus in Mt 5.37 Jesus is teaching his followers when it is that swearing is necessary. The necessity of swearing, Augustine explains, derives from "the evil of the man whose infirmity forces you to take an oath." ${ }^{132}$ Swearing [iurare] poses a great danger, not because it is wrong in itself, but because perjury [periurare], false swearing, is a sin. ${ }^{133}$

Augustine's commentary on Galatians reiterates the account of swearing developed in De sermone Domini in monte. In Expositio epistulae ad Galatas, he introduces Mt 5.37 when he examines the epistle's statement, "In what I am writing to

${ }^{129}$ s. Dom. mon. 17.51.

${ }^{130}$ s. Dom. mon. 17.51.

131 s. Dom. mon. 17.51.

132 s. Dom. mon. 17.51 .

${ }^{133}$ Augustine often testifies to the difficulty of breaking the habit of swearing, and he encourages his audience not to swear carelessly (See s. Dom. mon. 17.51, s. 180; s. 308). 
you before God, I am not lying."134 Augustine takes Paul's "before God" to constitute a swear and cites several other instances in which Paul makes similar statements. This verse would reappear in Augustine's polemics against lying and in his numerous pleas to Jerome that he retract his attributions of deception to Paul. ${ }^{135}$ Here, however, Augustine's attention is drawn to the "before God" which he asserts is "undoubtedly swearing.","136 This swear derives from evil, as Mt 5.37 teaches, and Augustine again locates the evil not in the apostle who swears but in "the unbelief of the person to whom he swears.",137 When it lies in a person's power to convince an interlocutor without swearing, then gratuitous swearing is the result of the evil within the agent. But if the deficiency is in the other's lack of faith or trust, then the evil that gives rise to the oath is not the agent's but the interlocutor's. Such swearing “is more than 'yes, yes' or 'no, no,' and therefore comes from evil, but the evil lies in the weakness or unbelief of those who are not otherwise moved to faith.",138

The lesson of Mt 5.37 regarding swearing in De sermone Domini in monte and Expositio epistulae ad Galatas is the same: 1) Swearing is not wrong in itself, 2) Swearing falsely is a sin, 3) Cases do arise in which another's evil necessitates that one swears, 4) Because swearing can develop into a habit and makes one vulnerable to swearing falsely, one ought to avoid it except in cases of necessity.

If this is the logic of Augustine's moral reasoning regarding swearing, why, we might ask, does the same logic not apply to lying? Might not lies too be necessary where

134 exp. Gal. 6.9.

${ }^{135}$ See s. Dom. mon. 17.51, mend. 15.28, epp. 40, 82.

136 exp. Gal. 6.9.

137 exp. Gal. 6.9.

138 exp. Gal. 6.9. 
one has in view a sufficiently good purpose? Augustine clearly thinks not, but to understand why we must see how his ethics of lying differ from his ethics of swearing. The differences in how these acts are evaluated by Augustine also hold implications for how we understand the relationship between the ethics of lying and his ethics of coercion broadly construed.

Mt 5.37 and six theses on lying

After two texts in which Mt 5.37 is engaged in relation to swearing, De mendacio returns attention to the issue of lying. Augustine's most consulted text on lying by other scholars, De mendacio was not his favorite. His Retractiones record his dissatisfaction: “it is somewhat difficult to understand ... obscure, and intricate, and altogether troublesome." ${ }^{\prime 139}$ Like his earlier philosophical treatises from Cassiciacum, Augustine makes no mention of the image of God in De mendacio. However, now, writing as a priest, he does draw extensively from Scripture both for the difficult cases that might seem to challenge or support his interpretation and for the numerous commands prohibiting lying with which he bolsters his argument. Although it sheds extensive light on Augustine's ethics of lying in 395, it adds little to our understanding of the way Mt 5.37 shapes his thinking at this time. Augustine cites the text once in a collection of verses that Augustine takes to prohibit lying absolutely. ${ }^{140}$

${ }^{139}$ retr. 1.26 (27).

${ }^{140}$ These texts include the Decalogue's prohibition of false testimony (Ex 20.16), Wis 1.11 (the most cited verse in De mendacio), Ps 5.7, Jesus' words in Mt 5.37, and Eph 4.25. Of his eight significant writings on lying, this is the only one that cites Ex 20.16. According to Augustine, this prohibition of false witness includes all lies whatsoever: "for whoever pronounces any statement gives testimony to his own mind." This mind- 
Enarrationes in Psalmos 5 also engages numerous scriptural texts important to Augustine's major treatises on lying. Remarkably, it also presents six theses that will become hallmarks of his ethics. De mendacio can be read as an expansion upon the six theses already evident in Enarrationes in Psalmos 5.7. The latter may well have provided an outline for, or perhaps summary of, De mendacio's argument given the remarkable overlap in these theses. They can be summarized as follows:

1) Lying is a sin, and sinning damages one's human nature.

2) Scripture does not condone lying.

3) Those who attain perfection tell no lies.

4) It is wrong to tell a lie to save a life.

5) Concealing the truth is not lying.

6) Prior to perfection, one should only lie out of necessity, and then seek pardon.

Whereas De mendacio invokes Mt 5.37 in a manner that suggests it relates to the prohibition of lying in a very broad, general sense, in Enarrationes in Psalmos 5 Augustine invokes Mt 5.37 in relation to quite specific theses regarding this ethics of lying. In Enarrationes in Psalmos 5 Augustine cites Mt 5.37 in relation to the second and third points in particular, but it is worth a brief examination of all six points that these two very different texts share, in part, because the meaning given to the "yes, yes; no, no" here has further implications where Augustine's development is concerned.

Enarrationes in Psalmos 5 states that Mt 5.37 is addressed by Jesus to those who are perfect [perfecti]. It is a counsel of perfection, not in the sense of a double morality where only an ordained or set-apart group is beholden to this command. Rather, it is a command toward which all are to strive and progress toward which merits divine reward. As in his Expositio quarundam propositionem ex epistula apostoli ad Romanos and witness pairing suggests, or at least anticipates, the inner-outer rendering that becomes more evident in Contra mendacio. 
Enarrationes in Psalmos 14, Augustine's exposition of Ps 5 teaches that perfection is attainable in this life. The Psalmist writes,

You are not a God to tolerate iniquity. The wicked person will not live close by you, nor will the unjust remain before your eyes. You hate all those who work iniquity; you will destroy all those who speak a lie. A bloodthirsty and deceitful person is loathsome to the Lord. ${ }^{141}$

Augustine groups together those who work "injustice, ill will, falsehood, murder, deceit, and anything else of this sort." $" 142$ The claim that God hates and destroys such persons is a figure of speech and ought not be understood literally, we are told. Rather, those who commit sins, including lying, destroy themselves in the act. The nature of one who sins is damaged, diminished, vitiated by the sinful act. This introduces the first of the six theses Augustine develops in this context.

1) Lying is a sinful act and as such damages one's own nature in the performance of the act itself. "But if anyone thinks that there is any substance [substantium] or nature [naturam] contrary to the truth, let that person understand that lying belongs to what has no being [ non est]." "143 Augustine interprets verse 7 through the lens of the metaphysics we observed above. Given his commitments to an ontological hierarchy of natures, and the corollary that evil is a privation of being, Psalm 5.7- "You hate all those who work iniquity, you will destroy all those who speak a lie" — need not be read as ascribing literal or immediate causation for the destruction that the human person experiences to God. Instead, the Psalm can be interpreted to mean that sinners who reject God's truth are the immediate cause of their own undoing, even as God may be ascribed agency insofar as

\footnotetext{
${ }^{141}$ Ps 5.5-8 [5.4-6]

142 en. PS. 5.5.

143 en. Ps. 5.7.
} 
the moral order in which human sin destroys the nature is ordained by God.

"Withdrawing from what is, they slide away toward what is not." ${ }^{144}$ By loving falsehood, those who speak a lie conform themselves to the object of their desire, to the nothingness that is the object of their love.

2) There are several possible ways of explaining why scripture appears at times to condone or even to praise those who lie. In those scriptural narratives where persons who tell lies are subsequently rewarded, Augustine asserts that it is never the lie itself that is rewarded but some other aspect of the deed. There will always be some other explanation for the occasional positive appraisals of these persons and events, and the possible explanations are in fact several. Those like the Egyptian midwives who persist in telling increasingly benevolent and less vicious lies "will deserve one day to be freed from lying altogether."145

For example, Augustine puts forward the possibility that "such things are praised not because of what happened but for the presence of mind shown," meaning the benevolence [benevolentium] rather than malice [malitia] with which the sin of lying was committed. ${ }^{146}$ Augustine points to the benevolence of the Egyptian midwives as the referent praised as opposed to the lie itself.

A related possible explanation is that the lies are praised because the particular lie manifests progress or maturation in moral development/virtue and in this respect merits commendation. Such a lie involves a less deleterious action than either the sorts of lies that this person had been accustomed to telling or the sorts of lies that this person could

144 en. Ps. 5.7. See also c. mend. 3.4.

145 en. Ps. 5.7. See Ex 1.19.

146 en. Ps. 5.7. 
have told in this situation. ${ }^{147}$ Enarrationes in Psalmos 5.7 does not provide a hierarchy of lies, but in the more expansive argument of De mendacio eight types of lies are ranked based upon subject matter and the intention of the lie. ${ }^{148}$ Whereas all lies are sins, not all lies are equally vicious. Although she who lies is guilty of sin, and a just judgment cannot acquit her of sin, she can be pardoned, and at times even rewarded, depending on the goods entailed in the lie or through punishment or penance. ${ }^{149}$ Given this hierarchy of lies, we see that there are no non-sinful lies for which one might justly be acquitted, some lies manifest progress in virtue and some will be more pardonable (requiring less penance) than others.

Although it is not raised in Enarrationes in Psalmos 5 or De mendacio, this is a useful place to note a third and more expansive explanation presented in Contra mendacium (420) for Scripture's seeming to praise a lie. In addition to the above possibilities, an apparent lie only seems to be a lie where the signifier's true referent lies elsewhere than perceived by the person who has adjudged the signification a lie. At times, the apparent lie finds its true referent, not apparent to some observers, in a spiritual, figural, or prophetic register. For example, although Jacob covers his arms with animal fur and says to his father Isaac, "I am Esau," according to Augustine, he does not lie. ${ }^{150}$ Speech that seems to be a lie is, in this way, truth for those who have ears to hear.

\footnotetext{
${ }^{147}$ See also $c$. mend. 16.33 .

${ }^{148}$ In order, from most to least sinful, these lies can be categorized as follows: teaching religion, injuring unjustly, benefiting one person but harming another, for the pleasure of lying, desire to please others; harms no one and benefits someone; harms no one and gives someone more time for repentance and conversion; harms no one and aids someone toward avoiding defilement.

${ }^{149}$ See also $c$. mend. 16.33 .

${ }^{150}$ See $c$. mend. 10.24 .
} 
3) Persons who attain perfection, whether in this life - a possibility we have seen entertained by Augustine prior to 396 - or the next, will tell no lies. Here, Augustine interprets Mt 5.37 as a prohibition not of oaths but of lying. He adds the verse that would become a refrain in De mendacio, Wis 1.11—“A lie in the mouth kills the soul." The effect that lies which proceed from the mouth have on the soul becomes a recurring theme in later writings. We saw this in De Trinitate 15.18-20 in which the mouth of the heart refers to the generation of words in thought, in the mind; and the mouth of the body refers to the mouth with which one eats and speaks. The mouth that lies and kills the soul is the mouth of the heart. ${ }^{151}$ When the mouth of the body speaks a lie, it has already occurred in the mouth of the heart, and it is the initial mental and volitional lie that kills the soul, even as the bodily mouth is the primary vehicle that signifies and conveys externally the internal lying word, verbalizing it to others.

4) There does not exist a good so great that its protection or preservation might justify telling a lie. Augustine knows that there are many goods other than truthful speech and observes that often these goods are mistakenly thought so valuable as to be capable of justifying lying. For this reason, it is salutary that scripture teaches explicitly that lying kills the soul. If one did not have the attestation of Wis 1.11 that lying kills the soul, "someone might think that the perfect and spiritual person ought to lie for the preservation of this temporal life, by the death of which no one's soul is killed, either the perfect person's or anyone else's."152 Temporal life is of little value in comparison with the life of the eternal soul, and it is the latter that lying itself destroys.

${ }^{151}$ See also $c$. mend. 2.3.

152 en. Ps. 5.7. See also c. mend. 2.3. 
5) Concealing the truth is not lying. Concealing, veiling, or withholding at least some portions of the truth is unavoidable. In interpersonal relationships, truly full disclosure is neither possible nor desirable. Only God knows all things in their entirety and even God spares the creature a full disclosure of all God knows and of which it is capable of knowing. In many cases withholding the truth and even concealing it proves not only beneficial but just. By concealing the truth or refusing to speak when it might contribute to saving someone's temporal life, one "avoids killing his own soul for the sake of another's body." ${ }^{153}$ Thus, there is no prohibition regarding concealing the truth corresponding to the prohibition of lying.

6) Lying, like any sinful action, is a temptation to which one remains susceptible until one attains perfection. Although he teaches that lying is always a sin, Augustine perceives that most of his audience will not yet have attained the growth in virtue required to discern and to liberate themselves from every lie. ${ }^{154}$ His Catholic audience remains capable of sinning, and when they do sin in those lies from which they are striving to be freed they should know that God continues to call them to repent, praying for forgiveness and for God's continued healing through the Holy Spirit at work in them. Augustine writes of those who have not yet progressed in virtue to the point of eschewing all lies that "if he is not yet able to do this, then he should tell only those lies which are necessary (necessitates), like those in the example above." ${ }^{\prime 155}$ He seems to have in mind the lies told out of a benevolent motive or to protect another's or one's own body. He continues, "In this way he will deserve to be freed even from those lies, if they are the

153 en. Ps. 5.7. See also c. mend. 5.15.

${ }^{154}$ See also $c$. mend. 20.40 .

155 en. Ps. 5.7. 
only ones left, and to receive the strength of the Holy Spirit, through which he may despise whatever has to be endured for the truth's sake." ${ }^{\prime 56}$ Those who lie only in this increasingly virtuous though still sinful manner have good reason to hope that God's grace might continue to purify them in response to their merits so that they will be able to endure the purging of this weakness as well. ${ }^{157}$ If they persevere in their penance and through good works rein in their vices, they too will attain the perfection of the saints evident in Scripture and will tell no more lies. "We have no evidence that perfect disciples have ever been allowed to make false statements." ${ }^{, 158}$ At this early date, Augustine imagines the disciples' perfection is attainable not only in the next life, but in this lifetime.. ${ }^{159}$ It is this perfection to which the yes, yes; no, no of Mt 5.37 calls all disciples to strive.

Augustine perceives in Mt 5.37 both the prohibition of lying detailed in these theses and the admonition not to swear. Both are explicated within a framework that understands habituation in human action as leading either to perfection or to greater susceptibility to $\sin .{ }^{160}$ The instruction by Christ not to swear oaths is a council of wisdom. It is not an absolute prohibition, as evidenced by the fact that the apostle Paul

156 en. Ps. 5.7.

${ }^{157}$ Interestingly, in en. Ps. 5.7 Augustine considers both jokes and promises broken without duplicity to be sins. They are "lies to which no great blame is attached, and yet they are not completely without blame." Jokes are "not very harmful" and broken promises might be less egregious for exhibiting "a certain amount of kindly goodwill." 158 en. Ps. 5.7.

${ }^{159}$ Believing Paul to have attained perfection in regulating bodily passions, overcoming concupiscence, Augustine interprets Rom 7 as a put-on persona where Paul speaks of willing one thing and doing another. See Simpl. 1.1.1-17; retr. 2.1.2. See also, James Wetzel, "Body Double: St. Augustine and the Sexualized Will," in Tobias Hoffman, ed., Weakness of the Will from Plato to the Present (Washington, D.C.: Catholic University Press, 2008), 58-81.

${ }^{160}$ On this habituation, see also ep. 157.4.40. 
swears in his letters. Nevertheless, oaths are not advisable because the more accustomed to the practice of oath-swearing one becomes, the more likely it is that one will swear falsely. If one's yes is simply yes, one's no is simply no, and one does not add an oath on top of one's affirmations, then one will never swear falsely. The relationship of lying to habituation in Augustine's moral reasoning is obviously quite different in spite of the shared framing in terms of habituation and perfection in virtue.

One significant feature of the ethic of lying from this early period that is developed more clearly in De mendacio than elsewhere is Augustine's explicit denial that there might exist a legitimate necessity for a lie. This sets lying apart from numerous other morally suspect acts. Swearing is sometimes necessary, killing is sometimes necessary, and later Augustine will add that error is sometimes necessary. ${ }^{161}$ Lying, however, because it is always sinful is not like these other acts that can be justified under conditions of necessity.

The reason for the exclusion of necessity from lying has to do not with the subsequent consequences, but with the effects inherent in the act itself due to the place of the rational soul in the hierarchy of goods. Although Augustine is aware of the Decalogue's prohibition and mentions it alongside other verses prohibiting lying, his moral reasoning shows that it is not exclusively or even primarily the divine command

${ }^{161}$ See, for example, s. Dom. mon. 17.51, s. 180.10, lib. arb. 1.5.12-13, civ. 19.7, ench. 5.17. We will see below that for judicial, political, and military officials it is necessary that they make judgments based on limited information knowing that some of these decisions will turn out to be errors. These errors are necessary as a result of one's duty to pursue the good in a situation where one lacks direct access to the minds of othersparticularly their ignorance, errors, and lies. 
that makes lying prohibited. ${ }^{162}$ In fact, in all of Augustine's major writings on lying, the Decalogue's prohibition in Ex 20:16 is cited only in De mendacio and there only in passing, without any commentary particular to the verse. The prohibition of lying is not an arbitrary divine fiat that makes lying evil. Rather, lying is absolutely prohibited because, as the most quoted verse in De mendacio teaches, "The mouth that lies kills the soul." ${ }^{\prime 163}$ Even a recognition of this fact, however, does not yet explain why it is that lying is never necessary. For, plenty of acts that involve evil (and even killing things other than the soul) prove necessary under certain conditions - including the attainment of some greater good by someone whose office and/or duty authorizes them to sacrifice one good for another. Unlike other types of acts, Augustine contends in De mendacio that "a sense of honor, of duty, or even of mercy" cannot justify lying in spite of widely-held beliefs to the contrary. ${ }^{164}$ Lying is distinct in that there does not exist another good greater than the rational soul that can be attained by a lie that sacrifices the rational soul in the act of obtaining another good.

In the hierarchy of goods the rational soul finds itself above all other created goods, and just below all eternal goods.

No one, then, can prove at times a lie is necessary unless he can show that some eternal good may be obtained by a lie. But, since every man withdraws from eternity in so far as he withdraws from truth, it is most

\footnotetext{
${ }^{162}$ Here again, we cannot agree with Decosimo's reading of Augustine as advancing a divine command ethic in which acts are determined as good or evil by divine fiat-i.e., for reasons that are merely God's own: "Often it seems Augustine thinks humans should do or not do D because God commands humans to do or not do D-and that God's reasons for so commanding or prohibiting are frequently his own" (Decosimo, "Just Lies," 686).

${ }^{163}$ Wis 1.11 . See mend. 5.6, 6.9, 16.31, 16.33.

164 mend. 1.1 .
} 
absurd to say that by withdrawing [from the truth] one is able to arrive at any good. ${ }^{165}$

Swearing, killing, and coercion in judicial, political, and military contexts are necessary, tragically, because of evil. However, it is the evil of others and the duties of one's position that make these acts of indeterminate moral species at times necessary. Lying does not attain any of these eternal goods but instead sacrifices the higher good of truth, turning away from it. Because only eternal goods like truth are higher than the rational soul, and because lies by their very nature abandon these eternal goods while at the same time killing the highest of temporal goods (i.e., the rational soul), these self-destructive acts are prohibited by God out of love.

Within this hierarchical ordering of goods, we can understand why it is that lying is always a sin and why duty and necessity that might justify other acts can never justify lying. There is no created nature higher in the chain of being that the rational soul, and it is this greatest of goods (other than God) that lying destroys. Whatever good one's lie accomplishes, then, is done at the expense of the rational soul that is by nature a greater good. Those who argue that a lie may be justified in order to attain a greater good or avoid a greater evil are in error. The nature of the rational soul and eternal goods are such that lying forfeits a greater good than any that it might obtain, and it commits a greater evil than any that might be avoided. ${ }^{166}$ As passionately as Augustine forbids that lying ever be justified, if there is anything he asserts even more forcefully, it is that Christ and Scripture be affirmed as absolutely trustworthy and without deception.

\footnotetext{
165 mend. 7.10 .

166 "Men make a mistake, because they substitute things that are worthless for those which are precious" (mend. 18.38).
} 


\section{Mt 5.37 in Christology and Scripture}

Where he cites Mt 5.37 in De agone Christiano (396/397) Augustine's concern is to teach three things: the veracity of the claim that the Word of God assumes a human nature, the sincerity of Jesus' teaching not to lie, and, again, the reliability of scriptural testimony. Written in the first years of Augustine's episcopate, it presents rebuttals of various heresies, including the docetic doctrine that the Son of God did not assume a real human nature but only appeared to be human. Docetic teachings are in tension with the affirmation of Jn 1.14, “the Word became flesh.” By denying a human nature was assumed in the incarnation Docetism suggests that Jesus' entire life was a deception, thereby violating Jesus' "yes, yes; no, no" that he understands as a claim not to lie or deceive. Thus Augustine writes, "they allege that the Truth has been guilty of a lie.."167 God does not lie. Jesus did not lie. And Scripture, authored as it is by God, does not lie. With characteristic wit, Augustine points to the potentially self-refuting nature of docetic doctrine and practice: "If they do not deceive their hearers they feel they are not imitating Christ." 168

Six years later in his third letter to Jerome, Epistula 82 (405), Augustine again appeals to Mt 5.37 to make largely the same points as those in De agone Christiano as well as in previous letters to Jerome. The preceding letters to Jerome, Epistula 28 (394) and Epistula 40 (397), do not cite Mt 5.37 but do provide a helpful contrast differentiating Augustine's ethics of lying and coercion. This is evident when Augustine

167 agon. 18.20.
${ }^{168}$ agon. 18.20. 
chides Jerome, "are you perhaps going to give us some rules by which we might know where it is necessary to lie and where it is not?"169 Just in case Jerome misses the sarcasm, Augustine lays it on a bit thicker, "please, do not explain it with lying and dubious reasons ... it is surely not a great fault by which my error favors the truth, if in your case the truth can correctly favor a lie." ${ }^{170}$ We have seen that Augustine himself had interpreted Jesus as providing guidance on when swearing was necessary, but he mocks the idea that there might be necessary lies. ${ }^{171}$

A consistent thread throughout these letters is Augustine's frustration with Jerome for suggesting that Peter and Paul colluded in telling a "useful lie" regarding Peter's circumcising Greeks for the benefit of the Galatian church (Gal 2). This leaves Augustine incredulous: "the fact that a man as fine as you are or someone else undertook the defense of the lie leaves me in more than a little pain." ${ }^{172}$ In Epistula 28 Augustine shares his reasons for taking this account of Paul's epistle as the worst sort of error: "For I regard it as absolutely disastrous to believe that there is a lie in the holy books, that is, that ${ }^{\text {those men }}$ who gave us and put into writing that scripture lied in their books." ${ }^{, 173}$ De agone Cristiano reaffirms what Augustine had been writing to Jerome, namely that God and Scripture should never be taught to lie. In Epistula 82 Augustine again pleads with Jerome that even if he disagrees with Augustine about the "yes, yes; no, no" in everyday life and holds to a belief in useful lies, that he will at least affirm "the authors of holy scriptures and especially the

169 ep. 28.3.5.

170 ep. 28.3.5.

${ }^{171}$ On the difference between lying and oaths, see also mend. 18.39.

172 ep. 28.3.3.

173 ep. 28.3.3. See also ep. 40 (397) in which Augustine repeats his plea that Jerome recant his interpretation. 
canonical ones were absolutely free from lies when they wrote." ${ }^{174}$ In the incarnation and in the scriptural witness, the "yes, yes; no, no" of Mt 5.37 teaches that God's assumption of a human nature and communication through human language is true and without deception.

Revisiting swearing: Moral dilemmas and outdoing murderers

Three sermons and a short anti-Pelagian treatise, all composed around 415, explicate Mt 5.37 in ways that return attention from lying to oaths and largely reaffirm the ethics of swearing advanced in the interpretations of De sermone Domini in monte and Expositio epistulae ad Galatas. In terms of the meaning given to Mt 5.37, these writings do not so much add new content to the meaning of swearing as demonstrate the evolving framework of moral reasoning in which it is discussed. All four of these textsEpistula 157 and Sermones 180, 307, and 308 - reiterate elements in the earlier writings: swearing to the truth is not a sin, swearing falsely is a grave sin, and for this reason swearing should be avoided except when necessary (necessity being understood as another's disbelief of some truth that would be good for them to believe).

In addition to Paul's example to which he had appealed previously, in these texts Augustine points to those Scriptures in which God is said to swear oaths (Gn 22.15-17; Ps 110.4). ${ }^{175}$ Augustine explains that God need not be cautious when swearing, because there is no danger of God swearing rashly or falsely: "The one who is incapable of lying

${ }_{175}^{174}$ ep. 82.2.22.

${ }^{175}$ s. 307.3, s. 180.2. See also, Trin. 15.15.24. 
can swear without qualm." 176 When human beings swear, because of their ignorance and error, they are always in danger of swearing falsely [falsa iuratione]—you can perjure "yourself even without intending to." ${ }^{, 177}$ For this reason, "rash swearing" [temeraria iuratione] especially should be avoided. ${ }^{178}$

Augustine explores the dangers of swearing rash oaths in the cases of King Herod and King David. ${ }^{179}$ Commenting on Herod's story, Augustine raises for the first time a concern that swearing an oath can put you in the position of "a choice between two evils ... a two-way snare. ${ }^{180}$ King Herod was put in a moral dilemma and reluctantly killed John the Baptist because he was caught in a rash oath. Similarly, King David put himself in a moral dilemma upon swearing a rash oath, though he handled the situation somewhat better than Herod.

David's dilemma arises after swearing a rash oath to kill the man Nabal who refused to give provisions to him and his men as they hid from Saul. By swearing the oath, David generates a binding norm whose violation is a moral evil, a sin. When Abigail, Nabal's wife, provides for David's men all they need, his anger relents and, according to Augustine, he chooses a lesser sin in breaking his oath than he would have in going through with murdering Nabal. "Of the two sins, he [David] chose the lesser, but it was only lesser in comparison to the greater one. Because simply weighed on the scales

176 s. 307.4 .

${ }^{177}$ s. 307.4. See also $s .180 .2$.

178 s. 180.2 , s. 307.1 , s. 308.

${ }^{179}$ See Mk 6.17-28, $1 \mathrm{Sm}$ 25, s. 307, s. 308. The feast of the beheading of John the Baptist provided the occasion for these sermons.

${ }^{180}$ s. 308.1. 
by itself, swearing a false oath is a great evil."181 We may infer that Herod, who "loved" John, chose a greater evil, but Augustine shows no hesitation in judging that by breaking his oath David became guilty of the "grave sin" [graue peccatum] of swearing falsely. ${ }^{182}$ The lesson to be learned is that swearing is "bad, bad, bad, yes exceedingly bad." ${ }^{183}$ In addition to the earlier concerns about swearing falsely, the dangers are made more evident in this period's exploration of how the proclivity to swear rash oaths creates unnecessary ethical dilemmas.

Another particularly sobering feature beyond the dilemma-creating possibility of rash swearing emerges in the discussion of the "yes, yes; no, no" both in Sermon 180 and Sermon 308. Augustine expands upon the earlier interpretation of Mt 5.37 that if you are challenged by someone else to swear then the necessity for swearing derives from the evil of the other person whose disbelief requires you to swear. Here, however, Augustine pursues this logic further in the case of a person who requires another to swear when the first person believes the other to be lying or in error. In a case where one believes another to be speaking falsely and requires the other to swear, Augustine extends his earlier logic and makes the person who requires the other to swear falsely guilty of the evil that brings about the sworn falsehood. Swearing falsely is a grave sin, as we have seen, and the evil that gives rise to this sin is as great as, if not greater than, the evil of murder.

If, however, he knows he's done it, is aware he did it, saw him do it, and still compels him to swear, he's a murderer. The other man, you see,

181 s. 308.2 .

${ }^{182}$ s. 308.1. Augustine is less explicit in the case of Herod than of David that breaking his oath would have been a lesser evil.

${ }^{183}$ s. 308.2 . 
destroys himself by his perjury; but this one both directs the hand of the slayer and presses it home. ${ }^{18}$

If you challenge someone to swear, and know he is going to swear to a falsehood, you outdo a murderer; because a murderer kills the body, you the soul - or rather two souls, both that of the person you challenge to swear, and your own. ${ }^{185}$

One should never demand someone to swear when one knows the other person to be lying or in error. To do so risks guilt greater than a murderer's.

Because swearing creates such great evils as these, the apostle James repeats Jesus' teaching but adds, "Above all," before quoting "Do not swear ... But let your word be 'yes, yes; no, no.", 186 Augustine could hardly raise the stakes any higher or be more forceful in cautioning against swearing. ${ }^{187}$ It is only because of the human being's inability to know another's thoughts and the necessity of confidence in another's speech that such a great evil may be risked.

This evil that requires oaths is not entirely analogous to the evils that necessitate other lamentable actions - it is far more pervasive. The swear that goes beyond the "yes, yes; no, no" comes "from an evil that is common to the human race since we are unable to see into each other's hearts." 188 Augustine allows that even he cannot escape from the necessity that this evil imposes upon human existence in the saeculum. He laments that if we could see into each other's hearts there would be no need to swear and pines for the day when the physical sight of the body is replaced by the sight with which the resurrected, spiritual body will discern the thought of others. In the here and now,

\footnotetext{
${ }^{184}$ s. 180.11 .

185 s. 308.4 .

${ }^{186}$ See $s .180 .11$.

187 s. 180.4 .

188 s. 308.3 .
} 
however, he confesses his own phronetic struggles to discern when swearing is appropriate.

For all that, I'm not telling you that I don't swear. I mean, if I do say that, I'm lying. As far as I'm concerned, I do swear; but as I see it, only when obligated to by great necessity. When I see that I won't be believed unless I do so, and that it's not in the interests of the person who doesn't believe me not to believe me, then after carefully weighing this reason, balancing this consideration, with great trepidation I say, "Before God," or "As God is my witness," or "Christ knows that that is what I have in mind." And I can see that this is more, that is to say it is over and above Yes, yes; No, no; but anything over and above comes from what is evil; even if not from what is evil in the person swearing, from what is evil in the person who doesn't believe. ${ }^{189}$

As perilous as swearing is, following the example of the apostle Paul, Augustine allows himself to swear only as a concession, only after considerable weighing of reasons, and only going beyond the "yes, yes; no, no" where the evil of another's disbelief necessitates it for their own wellbeing.

This mode of reasoning regarding swearing anticipates the justification of other more violent responses to the evil of others such as those offered in the discussions of the judge who must torture and the necessity of killing in war in De Trinitate 19.6-7. There too Augustine describes three of the above elements from which the necessity for these otherwise objectionable actions derives: an inability to see into another's heart or mind, the duty to pursue some legitimate interest on behalf of another, and the evil of another to which the otherwise unjustified action responds. ${ }^{190}$ In this formal sense, the justification of swearing resembles violent coercion in ways that lying, for Augustine, never could.

${ }^{189}$ s. 180.10.

${ }^{190}$ It bears mentioning that in the case of the judge who tortures, the source of the evil is disanalogous to the case of swearing. In swearing, the evil is the person's to whom one must swear in order that they believe what is in their interests to believe. In torture the 
Reframing lying in ecclesial and political contexts

Augustine's significant writings on the ethics of lying around 420 introduce less that is new in terms of content or the meaning given to the "yes, yes; no, no" than in the context and development of the moral framework in which this prohibition operates. Lying remains absolutely prohibited, but unlike the earlier texts around 395, the "yes, yes; no, no" is not a council of perfection attained only by those who achieve perfection in virtue. Thus, those cases in the Old Testament in which persons are apparently praised for lying are explained differently than had previously been the case. Furthermore, these letters around 420 are to ecclesial and Roman political officials unlike the earlier works on lying which included exegetical writings on the Psalms, the Sermon on the Mount, and Galatians, and the somewhat more philosophical treatise De mendacio. In these later letters Augustine counsels officials in regard to their public offices, duties, and necessities regarding the ethics of lying.

Contra mendacium (420) provides an exemplary statement of Augustine's more developed ethics of lying. Written a few years prior to the connections made between the

evil need not be the person's who is tortured, and it is not their individual interests that torture secures. Rather, the interests are those of "human society," and the evil that necessitates torture comes from a person who committed a crime. Augustine asks, given this situation, "Will the wise man take his seat on the judge's bench?" He answers yes. The wise man "does not think it a wickedness that innocent witnesses should be tortured in cases which are not their own" (civ. 19.6). The evil of criminals and the interests of human society require that wise judges "are often compelled to seek the truth by torturing innocent people simply because they are witnesses to the crimes of other men" (19.6). The discussion of war, on the other hand, is a nearer analogy to the necessity of swearing. As in swearing another's evil necessitates the swear, in war it is "the iniquity of the opposing side that imposes upon the wise man the duty of waging wars" for the sake of "eventual peace," including a common "language, as a bond of peace and society" (19.7). 
image of God and the ethics of lying in De Trinitate's concluding Book 15, it never mentions the image of God explicitly as it addresses practical questions of lying and coercion for ecclesial actors in the political sphere. Written as a letter to Consentius, a public figure and ecclesial leader to whom Epistulae 120 and 205 are also addressed, Contra mendacium is of a different genre than the more often quoted De mendacio, written 25 years prior. This later work of political moral theology is not a treatise in the abstract of indeterminate application, but a letter of instruction and correction regarding the public and ecclesial means of opposing the Priscillianist heretical teachings and practices.

Although differences between De mendacio and contra mendacium tend to be minimized by Christian ethicists, Contra mendacium clearly differs in comparison to the eight texts from 392-397 with respect to its moral reasoning and the altered framing of the prohibition of lying. ${ }^{191}$ Perhaps the moral reasoning and framing are overlooked by

${ }^{191}$ Boniface Ramsey writes that in Contra mendacium Augustine is "elaborating some of the principles already set down in De mendacio" ("Two Traditions on Lying", 508). Elsewhere, he writes, "The doctrine on lying contained in Contra mendacium adds relatively little to that found in De mendacio" ("De Mendacio/Contra Mendacium" in Augustine Through the Ages, 556). Decosimo finds that "there are no differences between the two texts that are relevant for our purposes" ("Just Lies," 662, n.3). Weaver does not see much difference between the texts in terms of content, though Contra mendacium is "a less clear denunciation of lies" in contrast to the "fairly theoretical character of $D e$ mendacio" ("Unjust Lies, Just Wars?" 56). Griffiths brackets the question of historical development, thereby implicitly assuming none in his chosen methodology: "my goal is not to provide a complete and historically nuanced account of Augustine on the lie. I want, rather, to lay bare the structure of his thought on the topic, its grammar and syntax, and to make constructive use and application of that structure" (Lying, 16). Feehan's three articles cite the two treatises interchangeably, without discussion of possible differences, since their shared "aim, as is well known, was to prove that the lie is not justifiable under any circumstances" ("Augustine on Lying and Deception," 132). von Heyking, quite unlike Feehan, reads De mendacio as a justification for lying intentionally written in such a manner "that Augustine's ideas will be clear only to the attentive 
scholars due to the common prohibition of lying at which both texts arrive and their shared assessments that Old Testament cases in which liars are praised are explained by features such as motivation, progress in virtue, and prophetic signification. Curiously, interpreters of Augustine on lying do not comment on the fact that it is no longer the case that a gradual progression through numerous steps brings one from an initial vicious practice of telling lies to everyone, then to all but strangers, then only to enemies, before finally attaining a final state in which the perfecti have sufficient virtue to eschew lies altogether. Instead of steps as in the earlier texts, in Contra mendacium there are simply two groups, two citizenships, neither of which attains perfection in this life and only one of which recognizes all lies as sins. This can be seen both in Augustine's discussion of Priscillianist lies in comparison to Catholics' and in a reappraisal of the cases of Rahab and the Egyptian midwives that appeals to Mt 5.37.

\section{Comparing lies: Priscillianist heresy and Catholic blasphemy}

In opposing the Priscillianist sect, Augustine requires that limits be observed by Consentius and his acquaintances, including the monk Fronto, in their efforts to flush heretical Priscillianists out of hiding. It responds to an earlier letter from Consentius detailing their practices:

I had ordered him [Fronto] the previous year to make war, while relying upon an utterly innocent ruse, against the Priscillianists, who swarm over

reader" (115), and he reads Contra mendacium — in which a "prohibition against lying is made clear" (114) - as more of a strategic, pragmatic, and politically motivated letter than as useful account of Augustine's genuine ethic of lying. von Heyking alone finds real conflict, because he interprets De mendacio as advancing an argument about the conditions that justify lying. None of these authors consider developments within Augustine's ethics in general or his ethics of lying in particular. 
Spain to such an extent that the barbarians seem to have done nothing of such magnitude in comparison to them. I had also taught him and certain other persons the trick by which he ought to attack them, sending to him the books that I was recently compelled to write at the command of my aforementioned lord, your brother, especially the third book, the one in which, after I learned everything more fully, the reason why I wrote in the guise of a heretic is noted in the text of the very brief preface. ${ }^{192}$

Augustine had come to know Consentius through their exchange of letters five to ten years earlier. ${ }^{193}$ Disturbed and perturbed that Consentius was not only sending out monks pretending to be heretics but also writing books misrepresenting himself as a heretic, Augustine responds with force and precision. ${ }^{194}$ Consentius must have been disappointed with Augustine's response. Instead of a careful reflection taking up the requested concerns in turn, and in spite of avowedly having read Consentius's letter carefully

${ }^{192}$ ep. $11^{*} .1$.

${ }^{193}$ See epp. 119, 120, and 205.

${ }^{194}$ After the execution of the Spanish Bishop Priscillian for heresy in 385, the Priscillian priest Dictinius had argued in his Libra that lying is justifiable in cases where Priscillianist religious beliefs are being discussed in the presence of outsiders to their community. Although Dictinius later publicly renounced and condemned the Priscillian heresy in favor of Catholic doctrine, there was no way for his followers to discern the verity of his conversion, and skepticism among Priscillianists and Catholics alike was, predictably, impossible to eradicate. When Consentius writes to Augustine informing him of the tactics employed by Fronto and unspecified other persons, he enquires what Augustine suggests ought to be done about the Priscillian heretics (See ep. 11*, one of the Divjak letters recovered in 1969 that, with the Dolbeau sermons discovered in 1990, have led Peter Brown, R.A. Markus, and others to reconsider their depiction of Augustine's treatment of the Donatists). Persons known to Consentius are citing Augustine's allowance that Donatist priests retain their ecclesial positions after renouncing Donatist schismatic practices and doing penance. It is not clear what of Augustine's response to the Donatist controversy was known to Consentius, but he seems to consider the retention of former Donatist priests as Catholic priests to be inappropriately lenient for the Priscillianist clergy whom Consentius deems less deserving. Consentius wonders if this is what Augustine would advise, noting "the Priscillianists who are worthy of every execration and of a different abomination, undoubtedly differ from the Donatists who, by the character of their crime, are cruel and violent" (ep. 11*.26). Consentius desires that Augustine's response should be sent to Patroclus and "should explain the difference among provinces, persons, and teachings and should inform us as to why different sentences ought to be pronounced" (ep. 11*.26). 
several times, Augustine musters all of his rhetorical acumen toward a single, emphatic demand: Stop lying. ${ }^{195}$

It is not clear whether Augustine's Contra mendacium was sent only to Consentius or also distributed more widely. ${ }^{196}$ What is clear is that this work does not present a novice reasoning and struggling to make up his own mind on the matter, but a seasoned rhetorician of settled conviction. Augustine is well acquainted with the reality that some lines of argument will prove more convincing than others to Consentius and to other officials, depending on their commitments and purposes. He thus provides numerous lines of argument to bolster his case.

Augustine vociferously rejects the proposal - and it may well have been Consentius's — "Let us lie in order to bring lying heretics to the truth." "197 Although familiar with the Priscillianist heretical doctrines_- "what the Priscillianists, according to the impious falsehood of their heresy, believe about God and the soul and the body and everything else" ${ }^{\prime 198}$ — what Augustine finds most pernicious is their teaching regarding lying. It is with respect to lying, above all else, that

they must be refuted, not imitated. We must not participate with the Priscillianists in that evil in which they are proved to be worse than all other heretics, for they alone, or at least they especially, in order to hide what they think is their truth, are found to give dogmatic sanction to lying. And this is the great evil they deem just, for they say that what is true must

${ }^{195}$ Slightly longer than De mendacio, Contra mendacium seems to have been the text Augustine has in mind in Enchiridion when he refers to his "long book" on lying, given that the description of the book that follows alludes to the shared practice of the Priscillian heretics and of Consentius's co-conspirators that included perjury and blasphemy (see ench. 6.18).

${ }^{196}$ Throughout the text itself Augustine addresses Consentius personally, but it may have been meant to be ciruculated, perhaps also to Patroclus and others.

197 c. mend. 1.1 .

${ }^{198}$ c. mend. 3.9. See also 5.9. 
be kept in the heart, but that it is no sin to utter what is false with the tongue to strangers. 199

This root must be dug out of Priscillianist heretical teaching and practice no less than it must be excised from the tactics of Consentius, Fronto, and their fellow conspirators. ${ }^{200}$

From the start of Contra mendacium Augustine calls upon Old and New Testament authorities to establish that lies are universally prohibited. According to Paul's Epistle to the Romans it is the height of absurdity to ask, "Why should we not do evil that good may come of it?"201 It is an analogous absurdity, according to Augustine, to propose, "Let us lie in order to bring lying heretics to the truth." In order to demonstrate that all lies are sins, God, in scripture,

has brought forth a universal proposition, saying: 'Thou wilt destroy all that speak a lie.' ... [A]re we to think, therefore, that room has been made for a certain kind of lie and that God will not destroy those who tell a

199 c. mend. 2.2 .

${ }^{200}$ One might reasonably wonder why Augustine did not refer Consentius to his earlier treatise dealing with questions of lying, his exposition of Psalm 5, or other texts on this topic. In De mendacio, at least, numerous cases are considered, including a judgment that the use of lying in teaching about religion is the worst lie possible (See mend. 8.11, 14.25). One reason that Augustine might not merely point Consentius to these earlier treatises is that they do not address the particular case of lying to heretics. Perhaps Augustine wanted to clarify his position regarding this specific case and so did not merely have his other writings copied. Or, perhaps this occasion precipitated the failed search that would later lead him to comment that he had believed De mendacio to have been lost (See retr. 1.27 [26]). Or, and this would agree with my own reading, perhaps Augustine had come to think somewhat differently about lying and desired to pen a fresh account of his reasoning, even if the eventual conclusion remained largely the same. Regardless of his reasons for drafting a new treatise in response to Consentius, Augustine took the issue of how to respond to the Priscillianists to be of enough importance that it merited proposals fitted to the particular issues. For Augustine, nothing less than the integrity of Catholic doctrine and of scripture's reliability was at stake in Consentius' illadvised policy of lying in order to root out the Priscillianist heresy.

${ }^{201}$ This rhetorical question is a gloss on Rom 3.7-8: "But if through my falsehood God's truthfulness abounds to his glory, why am I still being condemned as a sinner? And why not say (as some people slander us by saying that we say), 'Let us do evil so that good may come'? Their condemnation is deserved!” 
certain kind of lie, but only those who tell unjust lies, not any lie whatsoever, because there are found just lies, too, which ought actually to be a matter of praise rather than reproach? ${ }^{202}$

It is precisely this line of reasoning — that certain lies are not sins but are just — which Augustine desires to see "blotted out or guarded against." ${ }^{, 203}$ It is no more the case that there are just lies than it is that one should do evil that good may result. The universal prohibition quoted here derives from Psalm 5.7, the exposition of which had earlier provided a context for Augustine's condensed form of the arguments in De mendacio.

Much of the first half of Contra mendacium seeks to persuade Consentius that lying to Priscillianists is counter-productive. Consentius wants Christians to lie about their beliefs regarding the doctrine of salvation in order to catch and bring into the open heretics, to teach them the truth, and to prevent their errors from harming others. In spite of such benevolent intentions that he shares with Consentius, Augustine argues that such a tactic is 1) inherently sinful and thus prohibited, 2) a more serious sin than either heresy or the lies of the Priscillianists, and 3) counterproductive to achieving the original aims of teaching truth and preventing error.

Advocating that Catholics lie has the consequence that interlocutors whom Catholics encounter in their endeavors either are influenced toward becoming heretics, are further invested in the heresy they already subscribe to, or become less inclined to believe the Catholic doctrines the Catholic liar advocates when speaking truthfully. Even the interlocutor who disbelieves the Catholic liar-and thus neither becomes a Priscillianist nor is confirmed in Priscillianist doctrine-will have no way, once the ruse

\footnotetext{
202 c. mend. 1.1.

${ }^{203}$ c. mend. 1.1.
} 
is over, of confirming whether the Catholic was lying in the case of claiming to be a Priscillianist or in the case of claiming to be a Catholic. Although the case is formally quite similar for the Priscillianist who lies about his own doctrine of eternal salvation, three differences are decisive according to Augustine. Whenever Priscillianists know themselves to be around Catholics, they lie, disavow Priscillianism as heresy and claim to uphold Catholic teachings. The result is that the doctrines they affirm are the true Catholic doctrines which are salutary to any who might be listening. Whenever Catholics lie claiming to uphold Priscillianist teachings, however, the doctrines they affirm are false. This "destroys the soul" of any who are listening and are thereby persuaded to believe the heretical teachings, and it "plunges further into the abyss" the souls of those who already affirm Priscillianist heresies by increasing their mistaken convictions. ${ }^{204}$ What is more, any Priscillianists present will cease their lying through which the true Catholic doctrines were being proclaimed, even if malevolently and duplicitously. For these reasons,

it is more pernicious or, to soften the term, more dangerous for Catholics to lie in order to catch heretics than for heretics to do so in order to remain concealed from Catholics. For, he who believes Catholics lying to make trial of others either becomes a heretic or is confirmed as such, but he who believes heretics lying to conceal themselves does not cease to be a Catholic. ${ }^{205}$

Thus, the Catholic, by lying about being a Priscillianist, brings it about that both he and the Priscillianist publicly advocate Priscillianist doctrines. Whereas, if he tells the truth about being a Catholic, both he and the Priscillianist publicly advocate the true doctrine of salvation. In this way, lying in order to catch Priscillianists is counterproductive and

${ }^{204}$ c. mend. 3.5 .

${ }^{205}$ c. mend. 3.5. 
unloving toward unwitting witnesses and passersby. As a practice, it fails to love these neighbors, spreading falsehood among those with whom God calls Catholics to share the true doctrines of eternal salvation.

What are the effects on the Priscillianists themselves when Catholics practice lying in order to disclose who the Priscillianists are and to free them from this heresy? If Catholics are successful in identifying the Priscillianists through lying, the Priscillianist will be all the more emboldened and self-assured in the conviction that it is sometimes right to tell a lie, given the Catholic's example that they too condone and practice such tactics. Additionally, there is no guarantee that the Priscillianist will either be freed from his heresy or convinced of the Catholic doctrines of truth, even if he claims to repent of prior heretical ways. ${ }^{206}$ Thus, at the very best, the lying Catholic could hope for the Priscillianist's conversion in doctrines of faith, whereas the sinful practice of lying for the sake of some allegedly greater good will have been reinforced rather than excised. In this case, "by this lie we shall be corrupted to that extent, and they only half-corrected, since we are not correcting them in their belief that one should lie for the sake of the truth."207 Those half-corrected Priscillianists will bear an additional burden of skepticism thereafter. Such is the predicament of Priscillianists pursued by Catholic lies.

Not only is the proposed practice of lying sinful and prohibited, and counterproductive for all Catholics, Priscillianists, and others present, but what is more, in their lies Catholics become worse blasphemers that the Priscillianists ever could be. This element of moral reasoning highlights the distinction between knowing and willing in

${ }^{206}$ Such was the shared Catholic and Priscillian predicament when Dictinius and five other bishops recanted at the Council of Toledo.

${ }^{207}$ c. mend. 3.6. 
Augustine's moral psychology. The Priscillianists blaspheme in error, not knowing that it is not they but Catholics who hold the true doctrine of faith. And, they err terribly, blasphemously teaching that "the soul is part of God and of the same nature and substance as He. This is a great and detestable blasphemy. For, it would follow that God's nature could be enslaved, deceived, and mistaken, could be perturbed and deformed, could be condemned and tortured." ${ }^{208}$ For Augustine, blasphemy is among the worst evils no matter who perpetrates it precisely because the subject matter of the false statement is the divine nature, the summum bonum. And yet it makes a great difference to Augustine whether the blasphemer does so knowingly and willingly.

When Priscillianists speak truthfully that which they believe, advocating their own heretical doctrines, they blaspheme God in teaching that the soul is of the same substance as God. This is not the Catholic God who is omnipotent, Truth itself, omniscient, immutable, impassible, righteous, and holy. In believing and proclaiming their blasphemous teachings, however, the Priscillianists at least have their own ignorance as an excuse for their error. They blaspheme precisely because they will to communicate that which they truly believe. Like the Apostle Paul, if they come to the Catholic faith, they will be able to say, "I formerly was a blasphemer but I obtained the mercy of God because I acted ignorantly." ${ }^{209}$ Augustine takes it to be a matter of some importance that error that arises from ignorance is itself a natural evil consequent of moral evil - i.e., the original sin of the Fall inherited by all human beings — whereas lying is a moral evil in itself because the will to deceive [voluntate fallendi] is ingredient to the

\footnotetext{
208 c. mend. 5.8 .

2091 Tim 1.13.
} 
lie. Priscillianists sin out of ignorance in their blasphemy. And they sin unknowingly in lying.

Catholics who in their lies promulgate the blasphemous Priscillianist doctrines of God and the soul do so not out of ignorance but both knowingly and willingly. ${ }^{210}$ Augustine observes,

Let us see what difference there is between the two blasphemers. A great deal you reply, for the Priscillianist says this actually believing it, whereas the Catholic, though he says it, does not believe it. Hence the former blasphemes unknowingly, but the latter knowingly; the former against science, the latter against conscience; the former is blind enough to believe falsehoods, but in telling them has at least the will to tell the truth; the latter secretly sees the truth, yet willingly speaks false. ${ }^{211}$

What is more, the Catholic who sins in this blasphemy-a blasphemy worse than the Priscillianist's because the blasphemy itself is knowingly willed—does so without any certainty that his good aims will be achieved. And, although it is not determinative for Augustine's moral reasoning with respect to the lie, we have already noted that, in fact, the prospects for success are not good. ${ }^{212}$ Becoming worse blasphemers than the Priscillianists themselves - because theirs is a willing blasphemy lacking the excuse of ignorance - the example set by the Catholic lies teaches potential converts that blasphemy itself is not forbidden but, at times, justifiable. This, Augustine cannot countenance.

If I blaspheme knowingly to catch him who blasphemes unknowingly, the wrong I do is worse than the wrong I apprehend. If I disown Christ

${ }^{210}$ Later, under the doctrine of mental reservation, it becomes possible in certain cases to construe the knowledge that one is blaspheming as a good thing. ${ }^{211}$ c. mend. 5.8 .

${ }^{212}$ It is important to note that the prospect for success is not a criterion to determine whether the lie might be just, but merely to establish an additional lack of utility on top of an already established lack of justice. 
knowingly to discover him who disowns Christ unknowingly, he whom I discover in this way will follow me to perdition, since I perish first in order to discover him. ${ }^{213}$

Far better are the effects when the Catholic does not lie, but by his very presence brings it about that the Priscillianist lies in order to conceal his allegiance. The lying Priscillianist teaches that the soul is not part of God but God's creature and publicly praises the Catholic God, the Catholic bishops, and martyrs - in each case affirming true Catholic doctrine even as he lies in claiming that this is what he believes. ${ }^{214}$ The Priscillianist heretic who is in error desists in his blasphemy and speaks the truth when he lies. The lying Catholic has no such consolation - in lying the Catholic both speaks falsely and blasphemes. "[I]f we, in order that they may reveal themselves to us, proffer this allegedly just lie to deceive and catch them, we both say that we belong to the blaspheming Priscillianists and, in order that they may believe us, blaspheme without excuse of ignorance." ${ }^{, 15}$ Whereas the Priscillianist either blasphemes while intending to speak the truth or proclaims true Catholic doctrine while intending to lie, the Catholic who pretends to be a Priscillianist both lies and blasphemes simultaneously. And, what is worse, the Catholic who commits not one but both of these sins, does so both willingly and without a claim to ignorance. Knowing the truth about God, the Catholic who determines to hunt Priscillianists through duplicitous speech does so with an intention both to lie and to blaspheme. ${ }^{216}$

${ }^{213}$ c. mend. 6.12 .

${ }^{214}$ Augustine again recalls the witness of the Apostle Paul, "The important thing is that in every way, whether from false motives or true, Christ is preached" (Phil 2.18).

${ }^{215}$ c. mend. 5.9 .

${ }^{216}$ A later tradition would develop around the doctrine of mental reservation that allowed for voluntary deception in cases where unspoken qualifications might be kept "in mind" 
For these reasons, Augustine exhorts Consentius to give his energies to teaching and writing against the error of the Priscillianist heretical teachings and practices, rather than lying to infiltrate their ranks. It is far better to appeal to their minds and engage them in arguments about the truth, thereby correcting their errors, than to engage in lying blasphemy - a blasphemy worse than the Priscillianists' own - in attempting to oppose their falsehood. Catholics had previously been successful in finding out Priscillianists without engaging in lying both when those Catholics that Priscillianists had sought to

when attempting to protect innocent lives or bring about some such good end. Augustine, however, interprets Rom 10.10 — "With the heart a man believes unto righteousness, and with the mouth profession of faith is made unto salvation"-in a manner that seems to rule out such mental reservations. To those who would argue that lying Catholics are not blaspheming Christ, since they retain their faith inwardly, Augustine presents Peter, Paul, and martyred Christians as his witnesses. Had the martyrs countenanced such mental reservations, they surely would have employed them - if not to avoid death or prevent suffering to themselves and their loved ones, then certainly for the opportunity to go on living and preaching the gospel more widely (See Phil 1.20-24). Conversely, had those others who denied Christ rather than face persecution countenanced such mental reservations, they would not have worried themselves about damnation for their denial and certainly would not have been so distraught in their repentance in the manner of Peter after his threefold denial (See Mt 26.69-75). No doubt, such tragic figures maintained their faith internally even when a fear of persecution, through moral weakness, led to denials that could easily have been qualified by a mental reservation had the persecuted Christian community allowed such a practice. With such exemplars (and cautionary tales) in view, Augustine reinterprets and incorporates in his own argument the same Pauline texts that the Priscillianists had used. They taught that one can lie with impunity to those who are not members of the community so long as one believes correctly in the heart. According to Augustine, Eph 4.25-"Put away lying and speak truth each one with his neighbor, because we are members of one another"-does not teach that one can lie to those who are not members of the community. Rather, Paul is exhorting Christians to act toward others in a way that reflects their rational capacity, present in all persons, that by grace may be renewed toward justification and sanctification. "These words were spoken thus because each one of us ought so to count a man as we wish him to be, even if he has not yet become what we wish ... [H]e with whom it is our business to see that he not remain a stranger must be regarded as a neighbor and not as a stranger" (c. mend. 6.15). Heretics who one wishes not to lie about their faith must be approached beneficently, in love, and this means the exclusion of lies, engaging their minds with well-reasoned arguments about the truth of Catholic doctrines. 
convert reported them and also when former Priscillianists converted to the true doctrines of the Catholic faith. Augustine views these strategies as sufficient and argues that such events will transpire "more readily if their impious error is upset by truthful arguments rather than false snares. Such arguments you ought to take pains to compose, since the Lord has given you the ability." 217 Augustine assures Consentius that his efforts in this venture will be effective and will achieve his desired aim. "They will be holy meshes in which our opponents will be caught by the truth, instead of being sought after by a lie ... By truth we must guard against lies, by truth catch them, and by truth wipe them out."218 The rhetoric is martial and coercive, yet the method suggests the might of the pen rather than the sword.

Comparing lies: Egypt, Jericho, and the heavenly Jerusalem

In Contra mendacium the Egyptian midwives' and Rahab's deception on behalf of the Israelite children and Joshua's men, respectively, provide the occasion for Augustine's appeal to Mt 5.37. Scripture praises Rahab and the Egyptian midwives who lied in ways that would be inappropriate if they were citizens of the civitas dei. These cases and numerous others in Scripture lead even "good people" astray, according to Augustine: "the prevailing opinion among men [is] that those lies are not thought to be sins." 219 Against this majority view that holds that some lies are "lesser sins" and may be justified as "compensatory sins," Augustine argues,

${ }^{217}$ c. mend. 6.11. Augustine confers this interesting bit of praise on Consentius's capabilities apparent in his writings against the Priscillianists.

${ }^{218}$ c. mend. 6.11-12.

${ }^{219}$ c. mend. 10.23 . 
He who says that there are some just lies must be regarded as saying nothing else than that there are some just sins, and, consequently, that some things which are unjust are just. What could be more absurd? ... what is contrary to the truth cannot be just. But who would doubt that all lying is contrary to the truth? Therefore no lie can be just ... no lie is just. Accordingly, when examples of lying are proposed to us from the sacred Scriptures, either they are not lies but are thought so for being misunderstood, or, if they are lies, they are not to be imitated because they cannot be just. ${ }^{220}$

If no lie is just, how is the praise of liars in Scripture to be understood? In the writings around 420, Augustine argues that such examples appear in the Old Testament to prophetically anticipate and signify that those who are not yet baptized citizens of the civitas dei - not yet regenerate - can nevertheless hope for and have a disposition toward its truth and justice. Augustine points out that the New Testament does not put forward any examples of lying for imitation. The temporal reward and favor bestowed by God upon these women in the Old Testament was "foreshadowing with prophetic significance something eternal."221 They were praised not for the righteousness of their action but for its benevolence, for its desire for the good, for "the intention of wanting to benefit someone and to harm no one."222 This praise and reward, then, indicates neither that the lie was not a sin nor that it was a lesser sin than a particular other alternative (as was the case in the dilemma created by rash oaths).

Augustine insists that the women from Egypt and Jericho were praised for their benevolent disposition toward the righteousness of the heavenly Jerusalem, the civitas dei. Importantly, that righteousness was not (yet) theirs nor was it a righteousness toward which they could make step-like progress apart from the regenerating presence of the ${ }^{220}$ c. mend. 15.31 .

${ }^{221}$ c. mend. 15.33 .

222 c. mend. 15.33 . 
Holy Spirit within. They were not praised, he argues, for the righteousness of their act, for their progression in virtue, or for the good consequences that resulted, but rather for their benevolent disposition. According to Augustine, they had acted commendably in relation to their context and culture. That is, they responded admirably when presented with the practical issue of "whether to tell a lie if it be for someone's welfare, a question that has vexed even the most learned, and that surely exceeded the competence of those poor women living among those peoples and accustomed to their habits."223 In their lies they sinned, but with their good intention they were "(although they did not know it) foreshadowing with prophetic significance something eternal." ${ }^{224} \mathrm{Had}$ they been citizens of the civitas dei, however, they would have been graced with an enspirited mind and thus a knowledge and a will capable of obeying Jesus' command not to lie.

And so, their ignorance of this, even as of other things which likewise they did not know and which are not to be known by the children of this world but only by them of the world to come ... At the time when Rahab did for the Israelite spies that work which was good and laudable in view of her state of life, she was not yet such that it be demanded of her: "Let your speech be 'yes, yes; no, no.','225

It was not until Rahab "went over to the people of God" that she could be expected to recognize and obey the prohibition of lying.

Augustine may seem to have two different ethics in view-one for the civitas dei and one for the civitas terrena. However, it would be more accurate to describe his framework as a single ethic that accounts not only for two eternal destinies but also for two types of people — the regenerate and unregenerate- - who live together, intermixed in

${ }^{223}$ c. mend. 15.33
${ }^{224}$ c. mend. 15.33
${ }^{225}$ c. mend. 16.33 
the saeculum between the ascension and the second coming. In his mind this ethic coheres with the framework of his soteriology and theological anthropology. His understanding of election, the two cities, and the regenerative, healing effects of the Holy Spirit upon the rational soul provides warrants for expecting different responses from the unregenerate and regenerate. ${ }^{226}$ Those should be praised who like Rahab and the midwives expressed a longing for the "good" from a location in which they are not (yet) citizens of the City of God, even if their longing ${ }^{\text {manifests }}$ within their sinful state. Those who are already regenerate and thus citizens of the heavenly city, however, should not expect praise for sinful actions that, by virtue of the Holy Spirit, they have the possibility of resisting.

But, when we inquire whether it is part of a good man ever to tell a lie, we are not inquiring about the man who still belongs to Egypt or to Jericho or to Babylon or even to the earthly Jerusalem that is in slavery with her children, but about the citizens of that City above, which is free, our eternal mother in heaven. And our inquiry is answered: "No lie is of the truth." ... Whenever any lie whatsoever steals (as it does among men) upon these children of the heavenly Jerusalem, the holy eternal City, they humbly ask pardon for it rather than seek glory from it besides.

Citizens of the new Jerusalem ought not expect God to respond to their lies as God did to the Egyptian midwives and Rahab, but should instead seek pardon and forgiveness through penance without expecting praise for having sinned with a good disposition.

Indeed, Augustine argues that if these women had been citizens of the heavenly city and refused to lie, their reward would have been even greater, not just temporal but eternal.

\footnotetext{
${ }^{226}$ These two groups do not map directly onto the citizens of the civitas dei and the citizens of the civitas terrena.
} 
If those Hebrew women were like them [citizens of the city above] of whom we inquire whether they ought ever to tell a lie, they would not say anything false and they would refuse the loathsome task of putting the babies to death. "But," you will say, "then they themselves would die." Yet see what would follow. They would die, indeed, in celestial dwellings, an incomparably greater reward than those houses could be that they made for themselves on earth. They would die in eternal bliss, having suffered death for truth most innocent. ${ }^{227}$

As for the detrimental consequences that others would have borne (i.e., the children and Israelites protected by the women's lies), "Surely, He who guarded them after the woman's lies could have guarded them even if she had not lied." ${ }^{, 22}$ For Augustine, it is clearly not the good consequences to which the women's action contributed that merits the praise they receive but precisely the benevolent disposition with which they acted. God's omnipotence and omniscience dictates that God has no need of human action in order to bring about the consequences God intends.

In short, the "yes, yes; no, no" once again establishes that all lies are sins, unjust, and yet those who violate the command do not all receive the same appraisal from Augustine. Again, it might seem that citizens of the heavenly city are held to a higher standard of moral progress than these women who are praised in spite of their lie. And, in fact, Augustine's ethic retains room for moral progress - a disposition toward truth, justice, and the good are still envisioned as necessary for moral progress that does occur for those empowered by the Spirit. However, it is not progress as such to which Augustine here appeals in explaining the scriptural praise of these women as was the case around 395 . He does not seek to differentiate between "steps" on an ascending route toward perfection. There is not a class of perfecti who have arrived on a morally blessed

${ }^{227}$ c. mend. 17.34 .

${ }^{228}$ c. mend. 17.34 . 
plateau populated by saints, apostles, and other committed disciples on which persons no longer actually sin. Rather than a gradual moral ascent framing the interpretation of the “yes, yes; no, no," Augustine has come to understand the possibilities for human action in the saeculum in light of the person's present state as either regenerate or reprobate. These two groups are not empirically distinguishable with certainty and they do not map directly onto the eternal division of persons into the citizens of the two cities in the present life, both because one cannot see into the heart of another and because the conversion of regeneration by which one identifies with the eternal heavenly city occurs at a particular point in time. ${ }^{229}$ Thus, some people who are at present unregenerate are eternally (in God's omniscient and omnipotent will) citizens of the heavenly city.

Within these framing distinctions, Augustine's presentation of the prohibition of lying suggests that the there are two possible outcomes (lying or truthful speech) in a case such as Rahab's, but in the saeculum these two outcomes generate four distinct moral evaluations depending on the soteriological status of the one who performs the act. The already regenerate person is capable, due to their enspirited existence, of submitting to the absolute prohibition of lying. Because of their ability not to lie, they will either receive eternal rewards for their obedience (the temporal consequences of which might include suffering and death) or they will have to do penance for their disobedient lying, even if the lie is performed with benevolence. Those not (yet) regenerate will either lie benevolently (prophetically signifying some eternal truth and perhaps foreshadowing their own forthcoming regeneration) and may receive some temporal reward for this, or

\footnotetext{
${ }^{229}$ See also $c i v$. 19.8, where Augustine entertains the possibility that a once-regenerate person might lose their faith.
} 
they will lie malevolently, in which case the evil infirmity of a corrupt nature and evil will are the just deserts of their disobedience.

In the divine, inscrutable, eternal will humanity is divided into the civitas dei and the civitas terrenae. In the saeculum, however, human beings encounter one another as regenerate or unregenerate. In Contra mendacium the four-stage framework-in which the saeculum involves a permixtum of individuals in stages two and three of the soteriological progression-informs the appraisal of cases that had previously been evaluated in terms of gradual, small steps in moral progress analogous to interpretations of the seven days of creation and eight beatitudes. In this later writing, the four stages of humanity, in which persons in the second and third stage populate the saeculum, provides the framing by which lies by regenerate Catholics receive a different appraisal than lies told by non-Catholics (the unregenerate).

The comparison of Catholic and Priscillianist lies demonstrates how it is that the intellect and will of the regenerate Catholic provide a context in which the guilt or culpability of the lie exceeds that of the heretic. Similarly, the consideration of Rahab shows that the unregenerate are eligible for praise and reward for actions for which they would be punished had they been in the position of the regenerate. Lying is always a sin, but because Mt 5.37 and similar texts are addressed to and acknowledged as authoritative only by the regenerate, the unregenerate break the moral law against lying without recognizing its legitimacy. It is when the unregenerate show evidence of a good will in spite of their ignorance and the degraded morals of their surroundings that they merit honor and praise, even as they violate the absolute prohibition of lying. 
Laurentius: The necessity of error

Just one year after composing Contra mendacium, Augustine writes another short work to another official, this time not to an ecclesial one but to a Roman city official named Laurentius. We know little about him beyond the epithet primum notorium urbis that Augustine ascribes to him. The treatise is a small handbook [enchiridion] of the Christian life that presents a sort of practical catechism for the non-theologian, "one that can be carried in the hand, not to burden bookshelves. ${ }^{, 230}$ It would prove to be an important work, representing a distillation of Augustine's mature thought across a range of theoretical and practical questions. Its structure and organization according to the virtues of faith, hope, and love (1 Cor 13.13) provides the basis for Thomas's Summa. ${ }^{231}$ The majority of the work is dedicated to the first virtue, faith, and addresses the following topics: God the creator; Christ the Redeemer; the Holy Spirit in the Church; forgiveness, penance, and judgment; and the two cities after the resurrection. In the section on God the creator, Augustine offers a discussion of ignorance, error, and lies that anticipates De Trinitate 15. He twice quotes the "yes, yes; no, no" of Mt 5:37, both in affirmations of an absolute prohibition of lying. Much as his Enarrationes in Psalmos 5.7 condenses the arguments of De mendacio, Enchiridion can be read as a recapitulation of his letter to Consentius, Contra mendacium.

Augustine counsels, and perhaps consoles, Laurentius regarding the lamentable and "miserable life" [uita misera] in which one must make best judgments based on limited knowledge in a world where error is rampant and people do not always speak

230 ench. 1.6.

${ }^{231}$ Augustine refers to the handbook simply as "On Faith, Hope, and Love" [De fide et spe et caritate] (ench. 33.122). 
“yes, yes; no, no." The fact that other people speak errors and tell lies puts Roman city officials like Laurentius in the unenviable position of having to make judgments and decisions "in order to preserve life" while hamstrung by considerable ignorance and uncertainty. Political officials must wager decisions knowing that occasional error in one's judgments will prove unavoidable. Error is necessary [error est necessarius] due to one's ignorance regarding who is telling the truth, who is lying, and which facts oneself and others are mistaken in believing. ${ }^{232}$

We have seen the influential role that necessity plays in Augustine's ethic of swearing, but here the role of necessity differs somewhat. Whereas the evil of another and their own best interests constitutes the necessity in swearing, it is one's own ignorance and the interests of "human society" [humanae societati] that necessitate otherwise objectionable and coercive actions on the part of the city official.

The roughly contemporaneous De civitate Dei 19 explores analogous necessities under which judgment and human action take place within Varro's three levels of society-household, city, and world [domo, civitas/urbis, and orbis]. ${ }^{233}$ In these three levels - duties to kin in the household, to society in the city, and to opposition of iniquity in the world — must be fulfilled under conditions that once again are marked by

\footnotetext{
${ }^{232}$ Augustine's claim here that "error is necessary" is more than a statement about the need for deception [fallor] in war or in dealing with the unjust. Of course, he holds that it is sometimes necessary to allow others to err, through keeping silent for example, though never by signification with an intention to deceive. And, he believes error is a necessary feature of human post-Fall existence given the deficiencies or knowledge, intellect, and will [cognitione, cogitatione, and voluntate]. But here he is saying that acting justly (without sinning) under conditions of ignorance brings it about that one errs, that such error is to be endured as a miserable necessity, and that the inevitability of such errors and their devastating effects for others should not preclude officials from pursuing social order and peace through coercive and at times violent measures.

${ }^{233}$ See civ. 19.5-7.
} 
ignorance. In relations with family and friends, "we do not know the minds of those with whom we wish to maintain peace," civil servants such as judges are frustrated by their “inability to discern another's conscience," and interactions with alien cultures are fraught after Babel because "men cannot communicate their thoughts to each other." ${ }^{234}$ In nuce, the miserable human condition is a combination of 1) the unavoidable ignorance regarding the knowledge, thinking, and will in the minds of one's friends and family, fellow citizens, and strangers, with 2) the unavoidable duties of kinship, human society, and opposing iniquity, and 3 ) the realistic recognition of the human propensity to lie and act out of an evil will. The reality of this condition necessitates that human beings risk error in their pursuit of peace and justice in the three levels of society through familial security, civic justice, and state-sponsored war. It is this reality of which Augustine speaks when he writes to Laurentius in his handbook on faith, hope, and love that because people do not speak “"yes, yes; no, no' ... from time to time error is necessary to preserve life." 235

These necessary errors Augustine has in view pertain to what he considers temporal affairs that are not matters of faith and are not mistaken judgments having to do with the knowledge of good and evil — they are errors in the order of natural evils rather than moral evils.

These errors, even if they are not sins, are nonetheless to be counted among the evils of this life, which is so subject to vanity that false things are here taken for true, the true is rejected as false, and what is uncertain is taken as certain. For, although these things do not belong to that true and certain faith by which we move toward eternal happiness, they do belong

${ }_{234}^{234}$ civ. $19.5,19.6,19.7$.

235 ench. 5.17. 
to the misery in which we are still living now. ${ }^{236}$

Having counseled Laurentius that he will make mistakes in his judgments and provided encouragement that he ought not be paralyzed by this recognition but accept civic responsibility, Augustine immediately excludes or withholds from this civic official the potentially powerful political instrument of lying. Lying is a certain injustice in the soul, whereas officials' necessary errors result merely in physical suffering and death.

As he does elsewhere, Augustine lays out his argument that all lies are sins, but not all sins are equally evil. Some are deficient of goodness in greater or lesser degrees and in different respects than others.

It seems certain that all lying is sin, but that it is very significant with what intention and about what matters a person lies. For a person who lies with the intention of helping somebody does not sin in the same way as one who lies with the intention of doing harm, nor does a person who sends a traveler on a different route by lying do as much harm as one who by lying deceives another and leads him to take an evil path in life. ${ }^{237}$

Whether speech constitutes a lie depends in no way either upon the verity of one's statement with respect to the reality of the world or upon the effect (i.e., whether the hearer of one's statement in fact becomes deceived thereby). That lying does not at all depend on the reality that obtains in the external world or on one's success in deceiving another reflects the fact that lying has to do exclusively with a relationship between the agent's speech and mind. "Everyone who lies speaks contrary to what is in his mind, with the intention of deceiving." 238 Although motivation and subject matter make some lies

\footnotetext{
236 ench. 7.21.

237 ench. 6.18 .

238 ench. 7.22. This standard definition of lying in Augustine's ethic is not yet the presentation that he offers in De Trinitate 15, where the lie pertains not to the mind and speech but to two words generated in the mind, neither of which is necessarily spoken.
} 
more culpable than others, a person who intends to lie, "whatever the nature of what he says in itself, has one thought hidden in his breast and another ready on his tongue, and this is the evil proper to the liar."239 The evil of lying is the willed inconsistency between what is believed and what is intended by one's signification. The "yes, yes; no, no" refers to a moral obligation that there be a correspondence between thought and speech. There is certainly lenience in doling out temporal praise and rewards relative to the goodness or evil of the will, but "it is enough to excuse their lying without praising it as well, especially in the case of those who inherit the New Testament, to whom these words are addressed: Let your word be yes, yes; no, no. Anything more than this comes from the evil one (Matt 5:37)."240

For Roman government officials and Catholic bishops alike, a world in which one could rely on the truthfulness of others' speech would have brought great relief, removing a significant portion of the misery in fulfilling one's official responsibilities. No doubt, the temptation to retain every tool and strategy in one's toolkit, including lying, would be great. Precisely because of this temptation, Augustine heralds the "yes, yes; no, no" of Mt 5.37 in these two letters to public officials in order to dissuade them from pursuing a course so disastrous for their own souls and the souls of others. Of course one ought not expect the unregenerate to acknowledge the legitimacy of the prohibition of lying, but Catholics ought to submit to it, whether private citizens or ecclesial or political officials, certainly for consequentialist reasons related to temporal affairs, but far more so for reasons of eternal goods.

239 ench. 6.18.

${ }^{240}$ ench. 7.22. 


\section{II.4 Three Stages in Augustine's Moral Reasoning about Lying}

We are now well positioned to step back and make a few observations about how the image of God and its development holds explanatory power for Augustine's ethics, his ethics of lying in particular, and, more focused still, the interpretation of Mt 5.37.

For much of his writing career, Augustine's theological reflection on the image of God and his moral reasoning about lying run parallel to one another. This is not to say that they are not related (they are) but rather that they do not converge; the relationship is not immediate. When the two streams of reflection do finally converge in De Trinitate 15 , this late confluence integrates the ethics of lying into the very core of Augustine's theological anthropology and ethics. This integration proves remarkable in light of previous reflections on the ethics of lying, and the new meaning that is given to Mt 5.37 in particular, as well as the way in which this sets lying apart as sui generis in comparison to other issues in Augustine's moral reasoning. Lying is distinguished from other acts that might be justified on the basis of duty, office, or necessity.

In Part I we saw that the referent of the image of God term ascends within the human nature across Augustine's writings. In De Genesi adversus Manicheos it refers to the orientation or disposition of a soul that is rational, as opposed to the souls of nonhuman animals. ${ }^{241}$ In De opere monachorum it refers not to the entire soul but to the rational, highest part of the human soul, the mind. ${ }^{242}$ And, in De Trinitate it refers to the

${ }^{241}$ Gn. adv. Man. 1.16 .28

${ }^{242}$ op. mon. 32.40. 
mind's specific capacity [potest] for the contemplation of wisdom as opposed to the mind's capacities for thinking about lesser goods. ${ }^{243}$

We noted as well that the metaphor of ascent used to conceptualize the development of the image of God can usefully be applied to Augustine's account of male and female which evidences a similarly ascending trajectory of development. ${ }^{244}$ The male and female pairing of 1 Cor 11.7 first signifies mind and concupiscence. ${ }^{245}$ Next, the pairing signifies the rational mind's capacity to act rightly and the non-rational "impulse to action." 246 Then, we are told that Adam signifies the contemplation of eternal

${ }^{243}$ Trin. 14.9.15.

${ }^{244}$ Numerous scholars have engaged Augustine's exposition of 1 Cor 11.7 and the figural interpretation of male and female. See, for example, Tarsicius Jan van Bavel OSA, "Woman as the Image of God in Augustine's 'De trinitate XII," in Signum Pietatis: Festgabe für Cornelius Petrus Mayer OSA zum 60 Geburtstag (Würzburg: AugustinusVerlag, 1989), 267-288; Kari Elisabeth Børresen, “God's Image, Mans' Image?: Patristic Interpretations of Gen. 1,27 and I Cor. 11,7," in The Image of God: Gender Models in Judeo-Christian Tradition, ed. Kari Elisabeth Børresen (Minneapolis: Fortress Press, 1995), 187-209; Kim Power, Veiled Desire: Augustine on Women (New York: Continuum, 1996); Constance E. McLeese, “Augustinian Exegesis and Sexist Canon from the New Testament," in Augustine and the Bible, ed. and trans. Pamela Bright (Notre Dame: Notre Dame University Press, 1999), 282-300; Mary McClintock Fulkerson, "The imago Dei and a Reformed Logic for Feminist/Womanist Critique," in Feminist and Womanist Essays in Reformed Dogmatics, eds. Amy Plantinga Pauw and Serene Jones (Louisville, Kent.: Westminster John Knox Press, 2006), 95-106; Janet Martin Soskice, "Imago Dei and Sexual Difference," Concilium (2006): 35-41; Margaret D. Kamitsuka, Feminist Theology and the Challenge of Difference (Oxford: Oxford University Press, 2007); Judith Chelius Stark, “Augustine on Women: In God's Image, but Less So," in Feminist Interpretations of Augustine, ed. Judith Chelius Stark (University Park, Penn.: Pennsylvania State University Press, 2007), 215-241; Kari Elisabeth Børresen, "The Image of God and Gender Models in the Christian Tradition," in In the Image of God: Foundations and Objections within the Discourse on Human Dignity, eds. Alberto Meloni, Riccardo Saccenta (Berlin: LIT Verlag, 2010), 359-367; Kari Elisabeth Børresen, "Challenging Augustine in Feminist Theology and Gender Studies," in The Oxford Guide to the Historical Reception of Augustine, ed. Karla Pollman (Oxford: Oxford University Press, 2013), 135-141.

${ }^{245}$ See op. mon. 32.40.

${ }^{246}$ conf. 13.32.47. 
truth and Eve signifies the management of temporal affairs - the one "directing," the other "conforming" — and that Adam's mind was enspirited in the Garden whereas Eve's was most likely not yet enspirited. ${ }^{247}$ Finally, in De Trinitate 12 , male and female signify the contemplation of eternal things and the active knowledge of things salutary for salvation. ${ }^{248}$ At each step in Augustine's exegesis the female's role ascends to occupy the space just below the male while the male consistently signifies an image of God term that is itself evolving, receiving increasing specificity over the course of Augustine's writings.

We are now able to add to the above developments that the "yes, yes; no, no" of Mt 5.37 manifests an evolution of its own. This can be presented in three stages made up of the early writings around 395, the later writings on lying around 420, and the final stage of De Trinitate 15. Throughout the stages, the "yes, yes; no, no" is like numerous other texts — including the Decalogue (Ex 20.16), Wis 1.11, Ps 5.7—in that Augustine consistently takes it as an absolute prohibition of lying. What changes across the stages, then, is not the strength of lying's prohibition but, rather, the explanations for liars being rewarded, the specific referents of the first and second terms in the "yes, yes; no, no," and what can be expected from whom in the saeculum.

The early ethics: Lying as imperfection in virtue

The early period is marked by a vision of the moral life as a step-wise progression toward moral perfection that is available to all. The later period is marked by an understanding of the "yes, yes; no, no" as absolutely and universally binding, even upon

${ }^{247}$ See Gn. litt. 3.22.34; 11.42.58-59.
${ }^{248}$ See Trin. $12.7 .9-12$. 
those who do not yet understand their accountability to this norm. Here, the "yes, yes; no, no" refers to the obligatory correspondence of thought to speech such that an outward false signification with the intention to deceive defines the lie that is prohibited. In $D e$ Trinitate 15, the "yes, yes; no, no" is integrated into Augustine's mature trinitarian theology and his Christology such that both terms occur within the rational soul itself. In the writings from 388 to 422 , we see nothing of the sort.

The early writings on lying from 392 to 397 exhibit much that corresponds to his early understanding of the image of God. The notion that human beings are on a gradual ascent in their moral perfection as they love God frames both the account of the image of God and the ethics of lying at this time. The concept of perfection in virtue provides a basic premise through which Augustine reads the six days of creation plus the seventhday Sabbath and the eight beatitudes (again, six days plus a Sabbath and an eighth day to signify beginning anew). ${ }^{249}$ Thus, it is hardly surprising to discover that within a year of writing De sermone Domini in monte Augustine constructs a theory of eight degrees of lying in De mendacio that are not repeated elsewhere. This framework of progress in one's moral life used in describing the renewal of the image of God-restraining concupiscence, putting to death sinful desires and habits while cultivating righteous ones_ manifests just as clearly in Augustine's writings about lying during this period. In both discourses, moral progress is imagined as an ascent consisting of gradual steps oriented toward and striving in the direction of the summum bonum or goodness itself, both of which God is.

\footnotetext{
${ }^{249}$ After 395, the gradual increase in virtue and its perfection continues to inform the penultimate and last of the four stages of humanity, respectively.
} 
Those who the biblical texts record telling lies and who are in the plain sense of the text praised for doing so, Augustine explains, are being commended for one of three reasons other than lying. The first reason Scripture casts liars in a positive light is that although they sinned in their lie, the particular lie that they told was of lesser degree than the particular person was accustomed to telling. That this lie was a less bad sin than might be expected was evidence of progress. Of course, this reason does not appear explicitly in the scriptural passages in question, but given the moral lens through which he reads the text (and his canonical reading of Scripture), it is a ready-to-hand way of reconciling these stories with the absolute prohibition of lying he discerns elsewhere. In these early writings, unlike later ones, Augustine compares God's use of persons in ways fitting to their stage in moral development to the use of a guard dog or an executioner. Morally deficient persons are rewarded for telling increasingly less vicious lies whereas the perfecti never lie.

A second possible explanation for the praise Scripture affords those who lie is not so much moral progress but the admirable motivation of the tellers of lies. Here too, there is a comparative element, but it need not be construed in terms of progress of the individual. Rather, the praise might index a particular feature of an act that the scriptural author (and God through the author) intends to bring to the intention of the reader. Although the lie itself is a sin, a moral evil, there may be good motivations or intentions that remain praiseworthy even when it goes without saying that the act itself cannot be condoned.

A third possibility is that the act being praised appears to be a lie to some readers but that such an act is praised in order to befuddle them. Augustine holds that some 
scriptures are difficult teachings providentially given to readers in order to exercise their minds. Quite often, for example, what appear to be bald-faced lies in scripture are not lies at all but prophetic significations. So, Jacob (Israel) stealing Esau's birthright by lying to Isaac signifies the future dis-placement of Israel by the Gentiles in the new covenant established by God. ${ }^{250}$

In his earliest writings, all persons, whether unregenerate, regenerate, Jew, Egyptian, Gentile, or Christian, appear on the same path of moral development, even if there are many steps and some are ascending, making moral progress, while others are descending to their detriment. Framed in terms of virtue, this portrayal does not disappear in the later writings but, like the image of God, is transposed into the third stage where the regenerate experience renewal after their initial conversion. Augustine is far less sanguine about moral progress among the unregenerate in the later writings and stops invoking the progress made by them as the reason for their rewards, while retaining and indicating, instead, that it is their motivation or prophetic significance which is being rewarded in proleptic fashion.

Where great emphasis is placed upon these two groups in the later writings, there is no discussion analogous to the earlier invocations of the natural law. In the earlier writings it was deemed fitting that God would command or allow certain persons to lie based upon their cruel disposition, nature, or stage in moral progress. In the later writings, the distinction between the regenerate and unregenerate (a temporal anticipation of the

${ }^{250}$ Gen 27.19. See mend. 5.5 and c. mend. 10.24. In the latter, Augustine adds the possibility of figural, prophetic significations such that Jacob's words and actions that have their proximate cause in Isaac's questioning are shown to be true: "When the things signified are true, at least in some past, present or future sense, without doubt it is a true signification and not a lie" c. mend. 10.24). 
two eternal citizenships) becomes the primary distinction on the basis of which what is "fitting" is determined. It is never fitting that the regenerate receive praise or temporal reward for lying because, being regenerate, they should know that lying is always sinful and cannot be justified. The unregenerate, though their lies remain sins, can still be praised on certain grounds (such as the benevolent motivation of the lie) but the proposal that lying befits them, either due to the natural law or due to their few steps on the long journey of continual moral development, no longer features among the legitimate reasons.

The later ethics: Lying, error, and necessity

Shortly after the early writings, in De opera monachorum (401), Augustine asserts for the first time that the human being is the image of God (imago dei est). Prior to this, he had claimed that the human is to the image of God (ad imaginem dei) and that the second person of the Trinity, God the Son, is the image and likeness of God to whom human beings had been created. At the end of Confessiones (c. 400), Augustine modified this earlier understanding in an important respect when he asserted that the human was created to the image of the Trinity, not just to the image of the Son. Throughout this generative period of turbulence in Augustine's interpretations of the image of God, this concept is never made central to the ethics of lying, and it does not help Augustine explain the prohibition of lying.

Unlike other texts that prohibit lies, Mt 5.37 helpfully highlights the role of the two "words" in the Trinity and the image of the Trinity in Augustine's late ethic of lying and also the distinctiveness of the ethics of lying in comparison to the ethics of swearing. 
Whereas lying is inherently sinful and ought never be done, swearing is not sinful in itself. Rather, swearing risks facilitating sins because habitual swearing leads to false swearing (when one is in error) and rash swearing can lead to dilemmas of having to choose between two sins (i.e., breaking an oath and thereby swearing falsely, or performing an act that one ought not have sworn to do).

In his handbook for Laurentius we saw that Augustine employs the "yes, yes; no, no" in discussions of both error and lying. Augustine portrays the necessity of error as a situation that is in some ways analogous to those of the household, city, and world that he discusses in De civitate Dei 19.5-7. To preserve life in the saeculum one will err out of necessity, in part because one cannot always trust another to speak "yes, yes; no, no," much as the necessity of torture derives from not knowing what another is thinking. Whereas these necessities are sometimes driven by ignorance (and an awareness of the post-Fall human propensity to $\sin$ ), there are other cases where it is a moral evil that necessitates action. Swearing, for example, is necessitated not by one's own evil but another's, just as the iniquity of the opposing side necessitates that the wise person wage war in the pursuit of temporal peace. All of these necessities that are analogous and disanalogous in various ways - error, swearing, torture, and war-present a stark contrast to the ethics of lying.

Why cannot the evil of another justify a lie, if it can justify swearing an oath? Why cannot one's office justify a lie — whether the ecclesial duty of making provision for the salvation of others, or the civic duty of establishing the peace of human society? Why is it that error, swearing, killing, torture, and sometimes war are necessities in the saeculum, but there is no necessity for lying? 
The reason, for Augustine, is quite simple in one respect: a lie is always a sin. But we have also seen the moral reasoning that explains why lying is always a sin is more complicated than a simple appeal to the divine command of the Decalogue or any other one scriptural text. Lying is always a sin, and taught to be such by scripture according to Augustine, because the lie relinquishes the truth rather than clinging to it; the lie cannot attain anything greater or protect against harming anything more valuable than the rational soul itself that dies in the act of lying. Lying is prohibited not only to private citizens or family matters, but to both ecclesial and political office holders. The moral species of a lie is determined in a way that killing, swearing, torture, and war are not. Thus, swearing is analogous to acts of violent coercion in ways that lying is not.

De Trinitate 15: Lying as the origin of evil in the rational soul

By the time Augustine comes to write Book 15 of De Trinitate, the "yes, yes; no, no" has expanded far beyond its earlier implications for oath swearing or lying to others. Augustine reinterprets the "yes, yes; no, no" in De Trinitate such that the second "yes" occurs not in the outer human, in relating sensibly to others, but within the rational soul itself with implications for every embodied action one takes regardless of whether speech and gestures to others are involved. Every sin, not only lying as he had previously presented it, now is construed as the result of a prior lie in the rational soul. The "yes, yes; no, no" takes on Trinitarian and Christological dimensions as it is expounded in the investigation of the immanent Trinity by way of analogy to the image of God in the rational soul. 
In De Trinitate 15, Augustine takes the "yes, yes; no, no" dynamic and he incorporates it — or better, animates it — bringing what had been a second word in the outer human into the animus, i.e., the rational soul qua image of God. Augustine's inquiry into the distinction between the immanent processions - the generation of the Son from the Father and the procession of the Holy Spirit from the Father and Son-led him to reflect upon the "yes, yes; no, no" of Mt 5.37 in four unprecedented ways. Augustine observes two senses in which the "yes, yes; no, no" in the mind, qua imago trinitatisdisplays a similarity to the Trinity and two ways in which it displays dissimilarity.

The first similarity is the pre-linguistic word generated in the inner human, when nothing more and nothing less is contained in the word in the thinking attention of intellect than is in the knowledge held in the memory, with the will holding them in agreement. In this case, the "yes; no" in the knowledge held in the memory is identical to the "yes; no" in the first, pre-linguistic word.

When, therefore, that which is in the knowledge is also in a word, then is it a true word, and the truth which is expected from man, so that what is in the knowledge is also in the word, and what is not in the knowledge is not in the word; it is here that we acknowledge the Yes, yes; no, no. In this way the likeness of the made image approaches as far as it can to the likeness of the born image, in which God the Son is declared to be substantially like the Father in all respects. ${ }^{251}$

The first similarity of the "yes, yes; no, no" is this perfect correspondence between the "yes" in the source and the "yes" generated, both in the immanent Trinity and in the prelinguistic word.

The second similarity pertains to the flesh-assuming Word and the sign-assuming word as the mediums through which the Trinity and its image operate ad extra. Just as

${ }^{251}$ Trin. 15.11.20. 
"all things were made through [the Word]" (Jn 1.3), and "the beginning of every work is a word" (Sir 37.16), so also all human works are made through a human word. A work is righteous or sinful depending upon whether the word chosen by the will is true or false with respect to one's knowledge of good works.

If it is a true word, it is the beginning of a good work. And a word is true when it is begotten of the knowledge of how to work well, so that here too one may apply the Yes, yes; no, no; so that if it is yes in the knowledge by which one ought to live, it should be yes in the word through which one has to work, and if no, no. Otherwise such a word will be a lie and not the truth, and from it will come a sin, not a right work. ${ }^{252}$

This second similarity of the "yes, yes; no, no" is the perfect correspondence between the "yes" in the knowledge of how to work well and the "yes" in the word through which one's good work ad extra is performed. This "yes, yes; no, no" is an image in the sense that the son is generated from the Father as the Word regarding righteous action-i.e., the Word is the Person of the Trinity through whom all of God's works ad extra are performed. Both the right work of the outer human and the work done in the incarnation are performed through a prior word /Word regarding the good.

Corresponding to these two similarities, there are two ways in which the "yes, yes; no, no" displays dissimilarity between the Trinity and the image of Trinity. In the divine simplicity of the immanent Trinity, being, knowing, and willing are one and the same. Father, Son, and Spirit are consubstantial, omniscient, and omnipotent such that there cannot be any ignorance, falsehood, or weakness in God's nature. Second, as in the immanent Trinity, so also in the incarnation, God's power is such that God-even in the

${ }^{252}$ Trin. 15.11.20. 
Word of God's assumption of human nature - is unable to err and unable to lie. The

Word perfectly and eternally knows and wills all that the Father knows and wills.

Two passages indicate that the power of the Trinity not to err and not to lie is

lacking in its image in the human mind. Both passages draw upon Jesus' teaching that he cannot do anything that departs from the Father's work (Jn 5.19). The first deals with the impossibility of error due to divine unity and simplicity regarding being and knowing.

For here [in God] knowing and being are one and the same ... it is as though uttering himself that the Father begot the Word equal to himself in all things. He would not have uttered himself completely and perfectly if anything less or more were in his Word than in himself. There supremely can we recognize Yes, yes; no, no. And the reason this Word is truly truth is that whatever is in the knowledge of which it was begotten is also in it; and anything that is not in that knowledge is not in it. And this word can never have anything false ... For, the Son cannot do anything of himself except what he sees the Father doing. He is powerfully unable to do this, nor is this weakness, but the strength by which truth cannot be false. ${ }^{253}$

It is not merely ignorance that is alien to the divine nature, but because there is no ignorance in the Trinity, no error resulting from falsehood is present either. The natural evils of error subsequent to the Fall with which the image of the Trinity must contend are unlike anything in God's perfect nature.

Analogously, the weakness of will that produces the moral evils of lying are nowhere to be found in the divine nature. In the image of the Trinity, there is not only ignorance in its knowledge and error in its pre-linguistic words, but also, due to the weakness of will, the possibilities of lying in its sign-assuming words and, thus, of sinning. This is a possibility for sign-assuming words in the image of the Trinity —as well

${ }^{253}$ Trin. 15.15.24. 
as the ad extra operations performed through this word - that is not shared with the fleshassuming Word of God in its inner triune life or in its temporal mission, the incarnation.

When we do this [lie] we willfully and knowingly have a false word ... But that Word which is God and is more powerful than us cannot do this. For he cannot do anything except what he sees the Father doing. And he does not speak of himself, but everything he speaks comes from the Father, because the Father speaks to him alone. And it shows the great power of that Word that he cannot lie, because there cannot be there any Yes and no; but only Yes, yes; no, no. ${ }^{254}$

In the immanent life of the Trinity and in the ad extra operations of the Trinity through the flesh-assuming Word, the Trinity is powerfully unable to err or to lie in the ways that its image can.

These four allusions to the "yes, yes; no, no" in De Trinitate 15 highlight two similarities and two dissimilarities between the Trinity and its image pertaining to prelinguistic and sign-assuming words. All four of these references occur within the rational soul, though the works of the outer human are ad extra operations performed through the second, sign-assuming word. That is, in De trinitate 15, both the first "yes" and the second "yes" occur within the inner human. As we have seen, this constitutes a departure from all previous interpretations of the "yes, yes; no, no" in which the second term is consistently interpreted as the speech or gestures of the outer human that (truly or falsely) signify a first term that is the true word held in one's mind.

In De Trinitate 15, then, we see several developments beyond even the later discussions of lying in Contra mendacium and Enchiridion. In De trinitate, lying is more primal in the account of human action and takes place within the rational soul rather than requiring an external signification in the outer human as in the earlier expositions. A

${ }^{254}$ Trin. 15.15.24. 
reconceptualization of lying takes place as a result of this internalization. Lying takes on a new meaning where it is portrayed as the source of every sinful action. It is no longer one among many species of sin, but sui generis as the source of every sinful work. What is more, lying is redefined as knowingly and willingly generating a false sign-assuming word regarding the knowledge of good works, without requiring a specific intention to deceive. In short, sins such as theft, adultery, or murder done without intending to deceive but only for the sake of sinning - as well as outer human lying that entails the voluntate fallendi - all find their origin in a prior lie in the rational soul. These new vistas emerge out of a brief and unprecedented confluence where the question of lying in the "yes, yes; no, no" of Mt 5.37 intersects with late reflections upon the image of the Trinity in the rational soul. In this exercise to discern the processions of the immanent Trinity, the unique place of Mt 5.37 in the ethics of lying receives its final and most distinctive interpretation through the Trinitarian and Christological reflections developed within Augustine's De Trinitate. 
Conclusion

Looking back over Augustine's account of the image of God, its development, and its ethical implications, we see several features of particular importance. First, the image of God in Augustine's thought is not static but a concept in via, always evolving. Second, where Augustine presents new facets of or judgments about the image of Godwhat it is and what role it plays in his moral reasoning - the warrants he provides for these positions take the form of biblical texts and biblical exegesis. Third, we have seen that developments in Augustine's account of the image of God correspond to developments in the figural signification of the male/female relationship and also map onto his ethics in ways that explain his differing judgments about the reasons for which lying is at times praised. In what follows I examine two additional ways that attention to the development of Augustine's thought contributes to understanding such basic features of his ethics as the valence of "necessity" and the constituent features of the lie (falsa significatio and voluntate fallendi). In these two cases, recognizing developments in Augustine's thought helps to resolve debates about the ethics of lying, and its place within Augustine's ethics as a whole. Finally, I end with a brief observation about what it might mean to provide an "Augustinian" account of the image of God for today.

The two motivating questions of this project have been, "What is the image of God for Augustine?” and, "What are its ethical implications?" How interesting or important one finds these questions about Augustine's account of the image of God, ethics of lying, and moral reasoning in general, depends on numerous factors - not only on one's estimation of Augustine's significance for assessing historical and contemporary moral thought, but also on Augustine's actual moral judgments and what one believes to 
account for Augustine's conclusions. ${ }^{1}$ That is, the reasoning that one imputes to Augustine for his conclusions influences greatly which conclusions are considered worth critically engaging, which judgments one affirms, and which opinions one dismisses. What if understanding Augustine's moral reasoning, and the basic commitments operative therein, provides reasons for modifying the very conclusions and judgments at which he arrived and that he believed to follow? Entertaining such possibilities requires looking beyond Augustine's stated accounts of the image of God and his moral judgments and attending the underlying reasoning by which he derives them.

By way of conclusion, then, I want to consider how this project's historicized reading of Augustine's thought, combined with attention to the prominent role of scriptural exegesis in his writings, might suggest a useful way of assessing what it might mean to pursue an Augustinian interpretation of the "image of God" for today. Specifically, I want to ask how this interpretation of the development of Augustine's thought with respect to the image of God and attention to his use of scriptures, particularly his use of Mt 5.37 in his ethics of lying, contributes to a more textured account of the Bishop of Hippo's thought.

My reading of the development of the image of God in Augustine's thought led to the observation that the scriptural texts to which Augustine repeatedly returns in his

\footnotetext{
${ }^{1}$ For Augustine's influence upon the institutions of Christendom and the Western political imaginary in general, see James T. Carroll, "He Promised Much and Did It All: Augustine and Historians," in Augustine and History, ed. Christopher T. Daly, John Doody, and Kim Paffenroth (Lanham, MD: Lexington Books, 2008), 77-88; and Henri Marrou, St. Augustine and His Influence Through the Ages [New York: Harper, 1957]). Hubertus Drobner conveys a scholarly consensus: "From the Middle Ages to the present, Augustine has remained the most prominent and widely studied author in Western Christianity, second only to biblical writers such as Paul" ("Studying Augustine: An overview of recent research," in Augustine and His Critics: Essays in Honor of Gerald Bonner, eds. Robert Dodaro and George Lawless [London: Routledge, 2000], 18).
} 
expositions of the image of God also provide the warrants for his modifications of earlier interpretations. This is true both when Augustine advertises that the current interpretation disagrees with another that he previously affirmed and when previous, alternative interpretations are not mentioned. As Augustine's understanding of the image of God develops gradually but significantly from the 386 dialogues onwards, Augustine repeatedly cites biblical texts as warrants at each transition, subsequently returning to these texts to bolster the accounts of the image of God in later writings. Augustine's reflections upon the image of God initially relate this term to a disposition of the rational soul toward the Word of God (the second person of the Trinity who is the image and likeness of God), and then to a disposition toward the Trinity, before identifying the image of God as being the rational soul, as no longer lost in the fall, and finally as the capacity for contemplating wisdom and the activity of reflecting upon wisdom itself.

Reading Augustine through the lens of his development also led to the identification of lying as the ethical question most central to the doctrinal motif of the image of God. Those accustomed to invocations of the image of God in contemporary appeals to human dignity may be surprised that Augustine absolutely prohibits lying but not acts of bodily violence, such as torture or capital punishment. At no point does the image of God as conceived by Augustine generate obligations analogous to the array of human rights that $21^{\text {st }}$ century Jews, Christians, and Muslims have derived from this biblical term. Augustine himself did not arrive at ethical conclusions about torture or freedom of religion and of conscience in his extensive expositions of the image of God, and not merely because he was a man of his time. Augustine's "image of God" simply does not fund these conclusions. Instead, his interpretation generates an absolute 
prohibition of lying, not because of an arbitrary or contingent divine command, but because of the natural hierarchy of goods and the place and purpose of the rational soul therein. In Augustine's moral imaginary the rational soul holds a place far above the body, indeed a position that even the resurrected body would not hold in its tranquil submission to the rational soul.

Although theologians have pored over Augustine's account of the image of God, ethicists generally have not. It is hard to discover scholars, other than Griffiths, who reflect on what the image of God contributes to our understanding of Augustine's ethics of lying. Similarly, lying is not a prominent or consistent theme in Augustine's writings on the image of God in spite of the fact that there are strong scriptural warrants in texts immediately proximate to those on the image of God (e.g., Col 3.9, Eph 4.25, and Jas 3.9). It is not these texts on which Augustine reflects in De Trinitate 15 where the image of God and the ethics of lying converge, but the "yes, yes; no, no" of Mt 5.37. As we have seen, this text stands out for other reasons as well —it is cited more often and more consistently than any other in Augustine's primary expositions of the ethics of lying. ${ }^{2}$

For these reasons, Mt 5.37 proves a useful thread to follow in tracing Augustine's moral reasoning about lying in two senses. First, the way that it functions in Augustine's moral reasoning helpfully highlights differences between lying and other ethical issues. Below we will see that this is particularly the case with respect to his use of "necessity." Second, Mt 5.37 highlights developments in Augustine's moral reasoning about lying that help resolve debates among scholars about the constitutive features of a lie.

\footnotetext{
${ }^{2}$ See Appendices C and D.
} 
One development in Augustine's moral reasoning has to do with the moral framework within which the reasons that some lies merit praise change. In the earlier texts around 395, either the virtue or motive of those not yet regenerate is praised. In the later ethics around 420, it is either the motive or the prophetic signification that is praised, but no longer one's step-wise progression in virtue. In both cases, Augustine is able to find features of lies commendable while remaining steadfast in his assertion that all lies are sins. What is more, in his earliest writings on lying, as in his earliest reflections on killing in De libero arbitrio, Augustine is capable of appealing to the natural law in affirming role-specific duties of an executioner, a guard dog, and the newly-formed and morally-primitive people of Israel. At this early stage in the development of his thought, Augustine asserts that it is appropriate for persons to tell lies commensurate with the step on which they stand in their own ascent in virtue. Now, if we read Augustine intertextually, we will not be given pause by the fact that these sorts of statements occur in Augustine's earliest writings, and we will pursue hermeneutical strategies in order to reconcile these natural law analogies with what he later writes in Enchiridion and Contra mendacium. It is understandable that scholars who privilege certain writings from the earlier period and also read Augustine intertextually utilize such interpretive moves as they argue that Augustine holds that some lies are justified. My account of the development of Augustine's thought holds that the moral framework with which he was working in these earlier texts explains why he arrived at the judgments he did then, while also identifying why the reasons he gives for the biblical praise of these lies change from the earlier writings to the later. 
A second development appears in the shift in referents of the two words (yes, yes; no, no) from thought and speech (inner and outer human) to pre-linguistic word and signassuming word (both inner, though the latter word is one through which works may be operationalized ad extra). This development is more basic to Augustine's ethic of lying as it pertains to the constitutive features of the lie, thereby enabling us to further deliver on earlier promises about bringing clarity to debates in secondary scholarship about the voluntate fallendi. After considering the voluntate fallendi we will return to the topic of necessity before concluding with the question of an Augustinian account of the image of God for today.

Defining the lie and the voluntate fallendi

Regarding the definition of lying and in particular the criterion of voluntate fallendi, reflection upon the image of God and attention to its development vis-à-vis the ethics of lying helped to arbitrate among several different interpretations. We noted that Augustine's usual definition, "A lie is a false signification told with an intention to deceive," is not repeated in De Trinitate 15. There, where Augustine is reflecting upon two words in the inner human, the second word must knowingly and willingly be a false word [falsum verbum]. Because this word is conceived in the inner human and need not be signified outward to another, the usual definition does not recur - there is no mention of the falsa significatio or the voluntate fallendi in this late definition of the lie.

We noted above that Griffiths and Decosimo disagree as to whether the voluntate fallendi is essential to the Augustinian definition of the lie. Decosimo and Griffiths agree that Augustine states that the voluntate fallendi is a constitutive feature of the lie. 
Griffiths, however, examines Augustine's moral reasoning about a particular case, and adjudges that what he takes Augustine to have meant by the voluntate fallendi manifestly was not necessary in this case of lying.

In this case, an agent must lie to a friend for that friend's wellbeing because for whatever reason the friend will certainly disbelieve what is said. The agent in this case does not intend to deceive the friend about what obtains in the world. The agent does intend to deceive the friend with respect to what the agent has in mind. On Griffiths' terms, however, this deception with respect to what the agent has in mind is already included in the falsa significatio. The voluntate fallendi therefore must refer to deception regarding what obtains in the world.

Griffiths observes that in this unusual case of an agent lying for the wellbeing of a friend, the voluntate fallendi is absent and thus non-essential to the lie. Decosimo is not alone in finding Augustine somewhat equivocal as to whether this case constitutes a lie. Because he accepts Griffiths' definition of the voluntate fallendi but (unlike Griffiths) takes Augustine at his word that the voluntate fallendi is necessary to the lie, Decosimo denies that this counts as a case of lying. How, then, does our account of Augustine's evolving thought help arbitrate this debate?

The fact that the voluntate fallendi is manifestly not necessary for the definition of the lie in De Trinitate 15, could lead to the conclusion that Decosimo is wrong and Griffiths correct in their respective claims about the necessity of the voluntate fallendi. However, the voluntate fallendi is essential for Augustine's account of lying where the lie refers to outer signification (which includes all of his writings prior to De Trinitate 15). Thus, the fact that both Decosimo and Griffiths have the correspondence between inner 
human and outer human (thought and speech) in view, and not primarily the two words in the inner human, might seem to reverse the judgment. With respect to the outer human, the voluntate fallendi is essential—-thus Decosimo would be correct and Griffiths mistaken. The matter is more complicated than this, however, because Griffiths and Decosimo share a mistaken judgment regarding to what the voluntate fallendi refers.

Both Griffiths and Decosimo collapse the noetic and volitional elements into the first element of the lie, the falsa significatio. This, they take it, requires that the voluntate fallendi must refer to something additional. For Griffiths, and Decosimo follows his lead in this respect, the falsa significatio is assumed to be already willed as false, and thus the question of the voluntate fallendi becomes one of why the agent wills to signify falselywas it for the purposes of a joke? to tell a children's fairy tale? or to deceive one's interlocutor? Griffiths and Decosimo think that the voluntate fallendi refers to this third possibility.

For Augustine, however, the falsa significatio does not aggregate the intellect and will as Griffiths and Decosimo suppose. The false signification may be a lie but only if it is willingly false. The voluntate fallendi satisfies this condition. It is possible for a person to signify falsely as well as willingly, yet without willing the signification to be false. A false signification of this sort is called error-it is willingly signified but not willingly false. What the voluntate fallendi adds to the falsa significatio is that it wills not only the signification, but also that the signification be false. Disaggregating the intellect and will allows us to see that the voluntate fallendi does not pertain primarily to the particular case of the disbelieving friend, but to all cases of lying. It specifies the distinction between 
error and lying, rather than the distinction between jesting, story telling, and lying as Griffiths supposes.

In terms of the image of God, what this means is that the inner lie that is being described in De Trinitate 15 is a different lie than the one that is under consideration in the earlier writings all the way up through Enchiridion in 422. That is, reading Augustine canonically on "lying" only confuses matters-it threatens to legitimate incorrect claims about whether the voluntate fallendi is essential. The voluntate fallendi is irrelevant to the falsum verbum in the inner human (as is the significatio) but it is essential to the lie that signifies outwardly through speech and gestures that which one does not have in mind.

In affirming that the voluntate fallendi both is and is not essential in these two periods and respects, however, we remain in disagreement with both Decosimo and Griffiths precisely because disagreement about whether the voluntate fallendi is essential does not consider the two lies we have had in view. Because these authors aggregate within the falsa significatio what we have identified as the two elements of falsa significatio on the one hand and voluntate fallendi on the other, they project the voluntate fallendi outside of the relation between thought and speech and into the relationship between the agent's mind and the mind of the friend. Augustine certainly has deep anxieties about the inability to know what others have in mind, but it is not this to which the voluntate fallendi refers.

The limits of necessity

With respect to necessity, the ethics of lying help to disclose what a complicated matter this is in Augustine's thought. Swearing, torture, and killing are objectionable, and 
yet Augustine's metaphysical conception of a hierarchy of goods creates conditions in which it is necessary that one good must be sacrificed in order to attain a greater one. When objectionable acts are justified in this way, their performance is still to be lamented, and we are to pray for our deliverance from these necessities. These acts result from evil—often the evil of the person who is killed, tortured, or to whom one swears, but it is also possible that the evil is not that person's but another's.

In torture, for example, the tortured person may endure suffering for an evil that they witnessed and about which the judge must pursue the truth for the good of "human society." ${ }^{3}$ In this case, the good of human society necessitates that the good of one person's bodily health must be sacrificed in order for the judge to achieve greater confidence regarding the truth of the torturee's testimony. Augustine knows and further laments that in spite of one's best efforts errors will be made, innocent persons will be killed, and the guilty will go free. Still, decisions and judgments must be made with a realistic awareness of one's own and others' ignorance, errors, and malevolent potential. This creates the conditions for having to act with partial knowledge and never knowing whom one can trust, or, as he tells Laurentius, with the "necessity of error" always in view.

For the most part, acts undertaken due to necessity are justifiable. They are necessary and involve evils, but not moral evil on the part of the agent. They are not necessarily sins. And yet we have also seen a rare case in which Augustine states that one must choose the lesser of two moral evils, the lesser of two sins. In the case of rash swearing by King David and King Saul, both kings created moral dilemmas for

\footnotetext{
${ }^{3}$ See civ. 9.6
} 
themselves when they swore that they would perform an act that would have been a sin. Either by failure of restraint or lack of foresight, each swear produced a catch-22 in which the best each king could do was the lesser sin. In both cases, this meant breaking an oath and thereby swearing falsely, a grave sin.

Unlike the great diversity of necessities that Augustine recognizes-from error and swearing to torture and killing — lying, he tells us, is never necessary. This dissimilarity between lying and other objectionable acts suggests that scholars such as Decosimo and Weaver who treat lying and killing as analogous, subject to the same forms of moral reasoning and justification, have failed to understand Augustine's moral imaginary, including the hierarchy of goods and the place of the rational soul therein. Lying is never a necessity and is not like other lamentable acts that can sometimes be justified. For Augustine, there are no just lies. Thus, Griffiths rightly observes:

A million innocent lives against the lie ... Only Augustine would accept the terms and ban the lie. The consistent Augustinian cannot lie to save innocent life, whether one or a million ... Should I lie to save the life of my child? No. Should I lie to prevent war, encourage peace, soothe the weary and discouraged, instruct the foolish, or liberate the innocent from torture? No. ${ }^{4}$

What this means for necessity is that this term is not a catch-all that can be used to justify lesser sins in order to avoid greater ones. ${ }^{5}$ Rather than sins, which are essentially a matter of the rightly ordered will, necessity is a way of talking about the hierarchy of goods and the lamentable misery of sacrificing lesser goods in an effort to attain greater ones. In the end, lying is never necessary because there is no greater temporal good than the image of God (i.e., the rational soul) and lying kills the soul without being able to attain any

\footnotetext{
${ }^{4}$ Griffiths, Lying, 230.

${ }^{5}$ In the very rare case of King David and King Herod in which it is a matter of lesser and greater sins, Augustine does not use necessity to exonerate David's better choice.
} 
greater good than the rational soul itself (i.e., an eternal good). Even before taking lying into the interior of the inner human and positing it as the source of every evil, Augustine already had good reasons for disavowing the necessity of lying. This is clearly Augustine's ethic, and yet, as paradoxical as it sounds, it is not at all clear that this ethic is as Augustinian as it might be.

An Augustinian account of the image of God for today

Augustine knew as well as any learned reader of Plato, Aristotle, or their lateantique progeny, that the rational soul [animus] is what distinguishes human beings from non-human animals. But it is under the tutelage of Ambrose in particular that Augustine's earliest understanding of Gen 1 is formed - the Son is the image and likeness toward which the rational souls of human beings were oriented in their Edenic state. This interpretation gave way over time as evidence in Augustine's six expositions of Genesis 1. Over time, Augustine comes to assert that the "Let $u s$... in our image" indicates that human beings were created in the image of the Trinity rather than with an orientation toward the Son. Similarly, expositions of 1 Cor 11.7 include the assertion that "man" [vir] is the image of God, which Augustine interprets figuratively to mean that the rational soul in the human is the image of God. Though he would assert on the grounds of Gen 1 that the "woman" too is the image of God, his interpretations of 1 Cor 11.7 consistently identify a (spiritual or figural) sense in which the woman is not the image of God but the glory of man. As we have seen, the sense in which woman is not the image of God would itself change over time in ways corresponding to the reinterpretation of the 
image of God. And later, Augustine would employ the veiling and unveiling metaphor of 2 Cor 3.18 in affirming that the image of God is not lost in the Fall.

As Augustine's account of the image of God develops, he draws increasingly upon features of nine biblical texts in particular-Gen 1.26-27, Rom 8, 1 Cor 11.7, 15.49, 2 Cor 3.18, 4.16, Eph 4.23-24, Col 3.9-10, and 1 Jn 3.2. He assigns the distinctions to which these texts refer (old and new, outer and inner, earthly and heavenly) to numerous distinctions that develop in his own understanding of the stages of salvation history (of individuals as of humanity) and as well as the hierarchy of the constituent parts of the human person. We have seen how these distinctions map onto analogous developments in Augustine's ethics of lying, but also how they inform the absolute prohibition of lying in a manner that differentiates lying from other issues such as swearing, torture, and killing. Numerous objectionable actions can be justified by necessity in a way that lying cannot due to the location of the rational soul in the hierarchy of goods and to the mechanics of lying by which an eternal good is relinquished for the sake of a lesser temporal good. Although lying cannot be justified, the condition of the person who tells the lie-whether they are living the unregenerate life of the old human or the regenerate life of the new human - as well as the motivation and subject matter, all bear greatly upon the sorts of evaluations of particular lies and the rewards or punishments that they merit.

Throughout his writings on the image of God and lying Augustine engages in a canonical reading of scripture that that seeks to reconcile texts that might seem in tension with one another. This intertextual approach is evident in his writings where judgments advanced within exegesis of particular biblical texts in which references to the image of God appear are gradually incorporated into and modify earlier interpretations both of 
particular texts and of the image of God. Augustine entertains figural, spiritual, or allegorical interpretations as well as literal ones when two texts seem to be in tension with one another. ${ }^{6}$ Whereas his interpretations of texts and conceptualization of the image of God develop over time, he remains committed to the maxim that scripture never lies and consistent in affirming that scripture teaches that all lies are sins. These Augustinian reading practices and interpretive commitments raise difficult and interesting questions about how we might assess Augustine's conception of the image of God on his own terms and how one might develop an Augustinian account of the image of God for today.

Specifically, it is not at all clear that what I have referred to as Augustine's "mature" understanding of the image of God ought to be affirmed as the Augustinian conception today. Perhaps more than anything else, this dissertation has disclosed that Augustine's interpretations of the image of God were always a work in progress. They were in principle revisable and manifestly provisional, precisely because of his more basic commitments to practices of exegesis and theological exposition of his biblical canon. If Augustine's more basic commitments and practices are taken as more definitive than the last in a series of evolving and contingent judgments, then the identification of an Augustinian interpretation of the image of God will prove more vexed even than the above accounts of Augustine's numerous proposals during his own lifetime.

To put the point slightly differently, we can only speculate as to how Augustine's understanding of the image of God would have continued to evolve had he been given the opportunity to engage, interpret, and incorporate additional biblical texts that he had not yet addressed during his lifetime. Likewise, it is not possible to know how engaging

\footnotetext{
${ }^{6}$ For example, Gen 1.26-27 and 1 Cor 11.7.
} 
additional texts might have informed reinterpretations of those biblical texts that he had previously engaged, as occurred on several occasions. An Augustinian account of the image of God for today, then, would seem to have the burden of exegeting, interpreting, and contemplating how biblical texts about which Augustine is silent might call for a continuation of the reformation of the image of God concept beyond what Augustine imagined or anticipated. More radically, participating in the Augustinian tradition might also require a reappraisal of the theological and moral frameworks that Augustine develops regarding the hierarchy of goods, the four stages of humanity, and the two eternal citizenships. Of course, the difficulty with such radical departures from Augustine's seemingly basic and Trinitarian-inflected natural, intellectual, and moral framework is that when both his judgments and relatively more stable frameworks are reduced to a contingent and provisional status, what remains are merely a practice of reading and a set of texts.

At the very least, it seems that an Augustinian account of the image of God today would likely attempt to address the challenge of incorporating those other biblical texts that had not yet been addressed in his writings but which other theologians before and after him had considered essential to interpreting the image of God. How would Augustine interpret, for example, the Gen 9.6 prohibition of shedding human blood because human beings are created in the image of God, and the Pauline claim that Jesus Christ is the image of God in 2 Cor 4.4 and Col 1.15?

We can only speculate what Augustine would have to say in response to those subsequent generations that would incorporate these scriptural texts more centrally or integrally into their interpretations of the image of God. Would he attempt to incorporate 
or be able to account for these claims within the framework he had constructed and which had attained an impressive inertia of its own by the end of his writings? Or, would he be open to the critiques of others who would fault his identification of the image of God with the rational soul that allegedly differentiates human beings as sui generis among creatures?

Scholars who identify strongly with Augustine on many other matters of theological, philosophical, and moral significance are at times able to affirm absolute prohibitions of torture and the death penalty on the grounds of Gen 9.6 that are more analogous in force to his absolute prohibition of lying than his prima facie opposition to swearing. ${ }^{7}$ This suggests that the cognitive dissonance between Augustine's imago dei and interpretations in which Gen 9.6 plays a central role might not be insurmountable. There might be ways of reconciling Augustine's image of God with Gen 9.6.

Assertions of a psychosomatic unity between the body and soul are one means of generating a prohibition of harming or killing the body, even if the image of God remains identified with the rational soul rather than the human body. In this case, the location of the image of God would remain restricted to the rational soul, while a more integrated sense of the mind-body unity funds a prohibition of physical violence. Thus, the old maxim — the mouth that lies kills the soul (Ps 5.7) — is joined by an analogous maxim—

\footnotetext{
${ }^{7}$ Regarding torture, William Cavanaugh writes that "for Christians, a proper understanding of our ultimate loyalty - to Jesus the tortured one-makes any support of torture unthinkable" ("Torture and Eucharist: A Regretful Update," in Torture is a Moral Issue, ed. Hunsinger [Grand Rapids, Mich.: Eerdmans, 2008], 91). In somewhat different moral reasoning about capital punishment, Paul Griffiths states, "This produces an effective ban on capital punishment in countries with efficient penal systems, even though the judgment that capital punishment may in some circumstances be required and proper remains in force" ("Just War: An exchange," First Things 122 [2002], 31-36). See also, "A Catholic Call to Abolish the Death Penalty" with upwards of 300 signatories (http://catholicmoraltheology.com/a-catholic-call-to-abolish-the-death-penalty/).
} 
whoever sheds human blood, by the human shall his blood be shed, for God created the human in the image of God (Gen 9.6). ${ }^{8}$ Where the body and soul are treated as a simple unity, the prohibition of Gen 9.6 might prohibit torture and killing with the same weight or strength that Augustine takes Ps 5.7, Wis 1.11, and Mt 5.37 to prohibit lying-which is to say, absolutely. ${ }^{9}$

Colossians 1.15 and 2 Cor 4.4 pose a far greater challenge to Augustine's mature account of the image of God as the rational soul's capacity for the contemplation of wisdom. In these passages it is not the male human (as in 1 Cor 11.7) but Jesus Christ who is the image of God. The identification of Jesus Christ as the image of God is quite explicit here, far more so than is the identification of the rational soul with the image of the Trinity in any of the other verses to which Augustine appeals in support of his interpretation. This creates potential difficulties for sustaining Augustine's interpretations of the image of God as the rational soul and of male and female as signifying the rational

\footnotetext{
${ }^{8}$ For a similar account, see Daniel Weiss's presentation of the classical rabbinic understanding of the image of God and Gen 9.6 in which the prohibition of killing is far more stringent than in Christian just war thinking (Weiss, "Direct Divine Sanction, the Prohibition of Bloodshed, and the Individual as Image of God in Classical Rabbinic Literature" Journal of the Society of Christian Ethics 32:2 [2012]: 22-38).

${ }^{9}$ On the other hand, one could affirm Augustine's arguments in which torture is accepted as a lamentable misery, and yet oppose modern torture on the grounds that it is a practice distinct from the one that Augustine allows. One might argue that although both forms of torture regularly include the infliction of physical pain for the extraction of desired information and allow for the possibility that the torturee might die in the process, only the modern version entails other more nefarious aims including the disintegration or the "unmaking" of the person under torture. Elaine Scarry offers an account of modern torture in which the "unmaking" of the human is the aim in The Body in Pain: The making and unmaking of the world (Oxford: Oxford University Press, 1985), esp. 27-59. See also, Talal Asad, "On Turture, or Cruel, Inhuman, and Degrading Treatment" in Social Suffering, eds. Arthur Kleinman, Veena Das, and Margaret Lock (Berkeley: University of California Press, 1997), 285-308; and Daniel Baraz, Medieval Cruelty: Changing Perceptions, Late Antiquity to the Early Modern Period (Ithaca, N.Y.: Cornell University Press, 2003).
} 
soul's functions of contemplation and active thought. How might Augustine reconcile these features of his "mature" account of the image of God with Col 1 and 2 Cor 4 ?

In his early writings at least, Augustine had identified the eternal Son as the image and likeness of God to which human beings had been oriented in their creation. And, in his later writings he equates the image of the heavenly human and the image of the Son with the immortal and spiritual resurrected body that human beings will have in the eschaton. Although the former is perhaps nearer, neither of these formulations affirms that the visible incarnate Christ is the image of God in the way that Col 1 and 2 Cor 4 do, or in the way that later theologians would. It is not entirely clear how Augustine might incorporate Col 1.15 and 2 Cor 4.4 were he to engage in an exegesis of these texts. Would he have located them with 1 Cor 15.49 and Rom 8.29 in the eschatological resurrected existence? Or, would he have somehow reverted to his earlier accounts of the image of God as that to which human beings are dispositionally properly oriented?

We observed earlier that Augustine has the rational soul in view when he writes that there are many "likenesses that are useful for understanding God with, as far as this is possible; but of such likenesses none is more suitable than the one which is not called God's image for nothing." ${ }^{10}$ By this statement Augustine meant to point the reader to the rational soul. According to Augustine, the rational soul "is not called the image of God for nothing."

On the grounds of Col 1 and 2 Cor 4 , later theologians would take the image of God term to point in a quite different direction. Although both hold Augustine in the

${ }^{10}$ Trin. 15.9.16. 
highest regard on so many other matters, Luther and Calvin alike oppose his mature

interpretation of the image of God. Luther writes,

What is that image of God according to which Moses says that man was made? Augustine has much to say in his explanation of this passage, particularly in his book On the Trinity. Moreover, the remaining doctors in general follow Augustine ... [but] they contribute very little toward the correct explanation of the image of God. ... I am not sure that they are very useful ... I am afraid that since the loss of this image through sin we cannot understand it to any effect. ${ }^{11}$

Calvin is equally critical of Augustine on this point but less pessimistic regarding identifying the term's intended meaning.

Now we see how Christ is the most perfect image of God; if we are conformed to it, we are so restored that with true piety, righteousness, purity, and intelligence we bear God's image. ... Now God's image is the perfect excellence of human nature which shone in Adam before his defection, but was subsequently so vitiated and almost blotted out that nothing remains after the ruin except what is confused, mutilated, and disease-ridden. Therefore in some part it is now manifest in the elect, in so far as they have been reborn in the spirit; but it will attain its full splendor in heaven. ... For that speculation of Augustine, that the soul is the reflection of the Trinity because in it reside the understanding, will, and memory, is by no means sound. ${ }^{12}$

Berkouwer expresses a similar dissent in the standard twentieth-century critique that "Scripture always speaks simply of man [adam, anthropos] as created in the image of God, and gives no warrant for considering only a part of man as partaking of the image. ${ }^{, 13}$ Like others, he opposes Augustine's identification of the imago dei with the

\footnotetext{
${ }^{11}$ Martin Luther, Lectures on Genesis, ed. Jaroslav Pelikan, Luther's Works Vol. I (Saint Louis: Concordia Publishing House, 1958), [§42] 60-61.

${ }^{12}$ John Calvin, Institutes of the Christian Religion, ed. John T. McNeill, trans. Ford Lewis Battles (Louisville, Kent.: Westminster John Knox Press, 1960), [15.1.4] 190.

${ }^{13}$ G.C. Berkouwer, Man: The Image of God (Grand Rapids, Mich.: Eerdmans, 1962), 63. This interpretation too, of course, does not yet address the particular issue of the humanity of Christ in Col 1 and 2 Cor 4. Useful accounts of the history of interpretations of the image of God can be found in David Cairns, The Image of God in Man (London: SCM Press, 1953); Karl Barth, Church Dogmatics III/1, ed. G.W. Bromiley and T.F. Torrance, trans. J.W. Edwards, et al. (Edinburgh: T\&T Clark, 1958), 192-197; Otto
} 
rational soul in particular and only derivatively with the human being as such. Others including Karl Barth, Stanley Hauerwas, David Kelsey, and Kathryn Tanner point not inward within the human or even to human nature as such, but rather, following Col 1.15 and 2 Cor 4.4, to the humanity of Jesus Christ. ${ }^{14}$

Reading Augustine today is a salutary, if fraught, undertaking. It reminds the reader of his or her own situatedness as the arguments, images, and cultural allusions alternate between alien and strangely familiar. For nearly two millennia readers have wrestled with his writings in that foreign time and place - whether such engagement was framed as ressourcement, the Protestant Reformation's hearkening ad fontes, or pietistic impulses. It is impossible to avoid the sense that Augustine is exhorting his readers still further onward. He would not have us rest in the penultimate experience of reading and reaffirming his texts, whether those be his earlier or later works, as if to establish a stasis that he never achieved and never intended others to attempt on the basis of his works. Quite the opposite, by his very praxis, Augustine points the reader beyond himself and toward the God he understood himself to be approaching in his exegetical pursuit.

Weber, Foundations of Dogmatics Vol 1, trans. Darrell L. Guder (Grand Rapids, Mich.: Eerdmans, 1981), 558-579; Anthony O. Erhueh, Vatican II: Image of God in Man (Rome: Urbaniana University Press, 1987), 1-57; and Kari Elisabeth Børresen, ed., The Image of God: Gender Models in Judeo-Christian Tradition (Minneapolis: Fortress Press, 1995).

${ }^{14}$ When asked about the image of God in a conversation, Stanley Hauerwas responded that he does not use the term, in part because he disagrees with the ways it is invoked by Christian ethicists, and in part because "I think the image of God is Jesus Christ." See also Karl Barth, Church Dogmatics III/2, ed. G.W. Bromiley and T.F. Torrance, trans. G.W. Bromiley, et al. (Edinburgh: T\&T Clark, 1960), 203-222; Kathryn Tanner, Christ the Key (Cambridge: Cambridge University Press, 2010), 1-57; David H. Kelsey, Eccentric Existence: A Theological Anthropology, 2 vols. (Louisville, Kent.: Westminster John Knox Press, 2009), 2:895-1051. 
Appendix A: References to the image of God in Augustine's writings

\begin{tabular}{|c|c|c|c|c|c|c|c|c|c|c|c|c|c|c|c|c|c|c|c|c|c|c|c|c|}
\hline $\mathrm{Yr}$ & Work & S & Source & $\mathrm{Vol}$ & 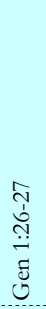 & $\begin{array}{l}\stackrel{n}{\ddot{n}} \\
\tilde{\tilde{D}}\end{array}$ & $\begin{array}{l}\stackrel{0}{\circ} \\
\ddot{\Xi} \\
\tilde{J}\end{array}$ & $\begin{array}{c}\stackrel{\infty}{\infty} \\
\stackrel{\infty}{\infty}\end{array}$ & 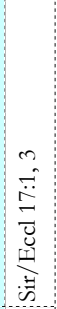 & 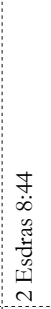 & 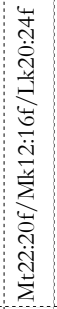 & $\stackrel{\overbrace{}}{\stackrel{\overbrace{}}{\Xi}}$ & 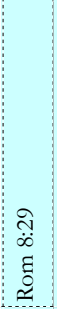 & 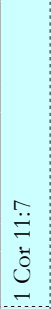 & 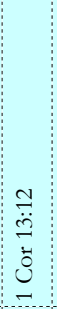 & 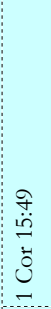 & $\begin{array}{c}\infty \\
\ddot{m} \\
\overrightarrow{0} \\
\sim\end{array}$ & $\begin{array}{l}\dot{+} \\
\dot{+} \\
\dot{0} \\
\sim\end{array}$ & $\begin{array}{c}O \\
\dddot{y} \\
\tilde{U} \\
v\end{array}$ & $\begin{array}{c}+ \\
\stackrel{+}{+} \\
\stackrel{+}{2} \\
\tilde{I}\end{array}$ & $\stackrel{\stackrel{n}{3}}{\ddot{\ddot{J}}}$ & $\begin{array}{c}0 \\
\ddot{0} \\
\dot{0}\end{array}$ & $\begin{array}{l}\stackrel{N}{\Xi} \\
\Xi\end{array}$ & $\begin{array}{l}\text { ले } \\
\ddot{y} \\
\tilde{g} \\
\text { s }\end{array}$ \\
\hline 386 & Acad. & & FOTC & 5 & & & & & & & & & & & & & & & & & & & & \\
\hline 386 & beata v. & & FOTC & 5 & & & & & & & & & & & & & & & & & & & & \\
\hline 386 & ord. & & FOTC & 5 & & & & & & & & & & & & & & & & & & & & \\
\hline 386 & sol. & 1.1 .4 & FOTC & 5 & 1 & & & & & & & & & & & & & & & & & & & \\
\hline 387 & imm.an. & & FOTC & 4 & & & & & & & & & & & & & & & & & & & & \\
\hline 388 & an. quant. & 2.3 & FOTC & 4 & 1 & & & & & & & & & & & & & & & & & & & \\
\hline 388 & an. quant. & 3.4 & FOTC & 4 & & & & & & & & & & & & & & & & & & & & \\
\hline 388 & an. quant. & $28.54-55$ & FOTC & 4 & & & & & & & & & & & & & & & & 1 & & 1 & & \\
\hline 388 & ep. 11 & 11.3 & WSA & III/1 & & & & & & & & & & & & & & & & & & & & \\
\hline 388 & ep. & $7.2 .3-5$ & W'A & $\mathrm{III} / 1$ & & & & & & & & & & & & & & & & & & & & \\
\hline 388 & mor & 1.19 .36 & WSA & I 19 & & & & & & & & & 2 & & & 1 & & & 2 & 1 & & 1 & & \\
\hline 389 & div. qu. & 12 & WSA & $\mathrm{I} / 12$ & & & & & & & & & & & & & & & & & & & & \\
\hline 389 & div. qu. & 18 & WSA & $1 / 12$ & & & & & & & & & & & & & & & & & & & & \\
\hline 389 & div. qu. & 23 & WSA & $\mathrm{I} / 12$ & & & & & & & & & & & & & & & & & & & & \\
\hline 389 & div. qu. & $51.1-4$ & WSA & $\mathrm{I} / 12$ & 1 & & & & & & & & & & & 1 & & & & & & 1 & & \\
\hline 389 & div. qu. & 58.2 & WSA & $\mathrm{I} / 12$ & 1 & & & & & & & & & & & 1 & & & 2 & & 0 & 1 & & \\
\hline 389 & Gn. adv. Man. & $1.17 .27-28$ & WA & $\mathrm{I} / 13$ & 1 & & & & & & & & & & & & & & & & & & & \\
\hline 389 & Gn adv Man. & 1.18 .29 & WSA & $\mathrm{I} / 13$ & & & & & & & & & & & & & & & & & & & & \\
\hline 389 & Gn. adv Man. & 1.19 .30 & WSA & $\mathrm{I} / 13$ & 1 & & & & & & & & & & & & & & & & & & & \\
\hline 389 & Gn. adv Man. & 1.23 .40 & WSA & $\mathrm{I} / 13$ & 1 & & & & & & & & & & & & & & & 1 & & 1 & & \\
\hline 389 & Gn. adv. Man. & $2.7 .8-9$ & WSA & $\mathrm{I} / 13$ & 1 & & & & & & & & & & & & & & & & & & & \\
\hline 389 & Gn. adv Man. & 2.26 .40 & WSA & $\mathrm{I} / 13$ & & & & & & & & & & 1 & & & & & & & & & & \\
\hline 389 & mag. & & FOTC & 59 & & & & & & & & & & & & & & & & 1 & & & & \\
\hline 390 & vera rel. & $43.81-47.90$ & WSA & $\mathrm{I} / 8$ & 1 & & & & & & & & & & & & & & & & & & & \\
\hline 391 & s. 210 & 210.7 & WSA & III $/ 6$ & & & & & & & & & & & & & & & & & & & 1 & \\
\hline 391 & s. 214 & & WSA & IIII $/ 6$ & & & & & & & & & & & & & & & & & & & & \\
\hline 391 & s. $375 B$ & & WSA & $\mathrm{III} / 10$ & & & & & & & & & & & & & & & & & & & & \\
\hline 392 & $e p .23$ & 23 & W'SA & $\mathrm{II} / 1$ & 1 & & & & & & & & & & & & & & & & & & & \\
\hline 393 & en. Ps. 94 & 94.2 & WSA & III $/ 18$ & 1 & & & & & & 1 & & & & & & & & & 1 & & & & \\
\hline 393 & f. et symb. & $6.13-9.18$ & WSA & $\mathrm{I} / 8$ & & & & & & & & 1 & & & & & & & & & & & & \\
\hline 393 & Gn. litt. inp. & $16.55-60$ & $\mathrm{WSA}$ & $\mathrm{I} / 13$ & 1 & & & & & & & & & & & & & & & & & & & \\
\hline 393 & s. 1 & 1.5 & WSA & III/1 & 1 & & & & & & & & & & & & & & & & & & & \\
\hline 393 & s. $260 \mathrm{~A}$ & & WSA & IIII $/ 7$ & & & & & & & & & & & & & & & & 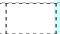 & & & 1 & \\
\hline 394 & c. Adim. & $5.1-2$ & WSA & $\mathrm{I} / 19$ & & & & & & & & & & 1 & & & & & & & & 1 & & \\
\hline 394 & c. Adim. & 12.4 & WSA & $\mathrm{I} / 19$ & & & & & & & & & & & & 1 & & & & & & & & \\
\hline 394 & en. Ps. 4 & 4,7 & WSA & III $/ 15$ & 1 & & & & & & 1 & & & & & & & & & & & & & \\
\hline 394 & en. Ps. 8 & 8 & WA & $\mathrm{III} / 15$ & & & & & & & & & & & & 1 & & & & 1 & & & & \\
\hline 394 & en. Ps. 9 & 9.4 & WSA & IIII/15 & & & & & & & & & & & & 1 & & & & $\cdots$ & & & & \\
\hline 394 & exp. prop. Rom. & 55.3 & Fredrick & sen Landes & & & & & & & & & 1 & & & 1 & & & 1 & & & & 1 & \\
\hline 394 & lib. arb. & & FOTC & 59 & & & & & & & & & & & & & & & & & & & & \\
\hline 394 & s. Dom. mon. & $1.3 .10 ; 4.11-12$ & FOTC & 11 & 1 & & & & & & 1 & & 1 & & & 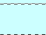 & 1 & & & & & & & \\
\hline 395 & div. qu. & 64 & WSA & $\mathrm{I} / 12$ & & & & & & & & & & & & & & & & 1 & & & & \\
\hline 395 & div. qu. & $66.1-4$ & $\mathrm{WSA}$ & $\mathrm{I} / 12$ & & & & & & & & & & & & & & & & & & & & \\
\hline 395 & div. $q u$ & $67.2,4,6$ & WSA & $\mathrm{I} / 12$ & & & & & & & & & & & & & & & & & & & 2 & \\
\hline 395 & div. qu. & 68 & WSA & $1 / 12$ & & & & & & & & & & & & 1 & & & & & & 1 & & \\
\hline 395 & div. qu. & $69^{\circ}$ & W'SA & $\mathrm{I} / 12$ & & & & & & & & & & & & & & 0 & & & 0 & & & \\
\hline 395 & div. qu. & 74 & WSA & I 112 & & & & & & & & & & & & & & & & & 0 & & & \\
\hline 395 & en. Ps. 29 & $29(2) .2$ & WSA & $\mathrm{III} / 15$ & 1 & & & & & & & & & & & & & & & & & & & \\
\hline 395 & en. Ps. 32 & $32(3) .16$ & $\mathrm{WSA}$ & $\mathrm{III} / 15$ & 1 & & & & & & & & & & & 1 & & & & & & & & \\
\hline 395 & en.Ps. 33 & $33(1) .10$ & WSA & III/16 & & & & & & & & & & & 1 & & & & & & & & 1 & \\
\hline 395 & en. Ps. 37 & 37.13 & WSA & $\mathrm{III} / 16$ & & & & & & & & & & & & & & & & & & & 1 & \\
\hline $395^{\circ}$ & en. Ps. 63 & 63.11 & WSA & IIII/17 & & & & & & & 1 & & & & & & & & & & & & & \\
\hline 395 & en. Ps. 101 & $101(1) .11,15$ & WSA & $\mathrm{III} / 19^{\circ}$ & 2 & & & & & & & & & & & & & & & & & & & \\
\hline 395 & en. Ps. 101 & $101(2) .12$ & WSA & IIII/19 & 1 & & & & & & & & & & & & & & & & & & & \\
\hline 396 & c. ep. Man. & 37.42 & WSA & $\mathrm{I} / 19$ & & & & & & & & & & & & & & & & & & & & \\
\hline 396 & doctr. Chr. & 1.22 .20 & WSA & $\mathrm{I} / 11$ & 1 & & & & & & & & & & & & & & & & & & & \\
\hline 396 & doctr. Chr. & $2.18 .28-20.30$ & WSA & $\mathrm{I} / 11$ & & & & & & & & 1 & & & & & & & & & & & & \\
\hline 396 & doctr. Cbr. & 3.7 .11 & WSA & $\mathrm{I} / 11$ & & & & & & & & & & & & & & & & & & & & \\
\hline 396 & en. Ps. 101 & $101(2) .12$ & WSA & IIII/19 & 1 & & & & & & & & & & & & & & & & & & & \\
\hline 396 & en. Ps. 63 & 63.11 & WSA & III $/ 17$ & & & & & & & 1 & & & & & & & & & & & & & \\
\hline 396 & 64 & & WSA & IIII $/ 3$ & & & & & & & & & & & & & & & & 1 & & 1 & & \\
\hline 396 & Simpl. & 3.2 & WSA & $\mathrm{I} / 12$ & & & & & & & 1 & & & & & & & & & & & & & \\
\hline 397 & c. Faust & 12.8 & WSA & $1 / 20$ & 1 & & & & & & & & & & & & & & & 1 & & 1 & & \\
\hline 397 & c. Faust & 22.27 & W'SA & $1 / 20$ & & & & & & & & & & & & & & & & & & & 1 & \\
\hline 397 & c. Faust & 32.18 & WSA & $1 / 20$ & & & & & & & & & & & & & & & & & & & 1 & \\
\hline 397 & c. Faust & $24.1-2$ & WSA & $\mathrm{I} / 20$ & 0 & & & & & & & & & & & 0 & & & 0 & 0 & & 0 & & \\
\hline 397 & c. Fel. & 1.12 & $\mathrm{WSA}$ & $\mathrm{I} / 19$ & & & & & & & & & & & & & & & & & & & 1 & \\
\hline 397 & c. Fel. & 2.2 & WSA & $\mathrm{I} / 19$ & & & & & & & & & & & & & & 0 & & & & & & \\
\hline
\end{tabular}


Appendix A: References to the image of God in Augustine's writings

\begin{tabular}{|c|c|c|c|c|c|c|c|c|c|c|c|c|c|c|c|c|c|c|c|c|c|c|c|c|}
\hline Yr & Work & is & Source & Vol & 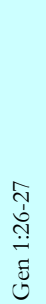 & $\begin{array}{l}m \\
\stackrel{n}{n} \\
\tilde{D} \\
0\end{array}$ & $\begin{array}{l}\stackrel{D}{0} \\
\ddot{\Xi} \\
0\end{array}$ & $\begin{array}{l}\stackrel{\infty}{\infty} \\
\stackrel{\infty}{\infty}\end{array}$ & 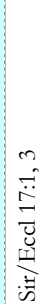 & 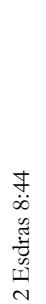 & 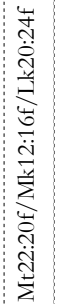 & 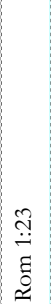 & 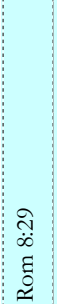 & $\stackrel{\sim}{\vec{J}}$ & 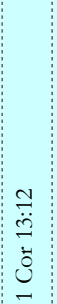 & 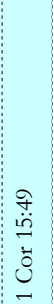 & $\begin{array}{c}\infty \\
\ddot{m} \\
\vec{b} \\
\sim\end{array}$ & $\begin{array}{c}+ \\
\dot{+} \\
\vdots \\
0 \\
v\end{array}$ & $\begin{array}{l}\stackrel{0}{\dot{y}} \\
\dot{+} \\
\stackrel{d}{N}\end{array}$ & 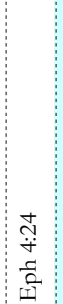 & $\stackrel{\stackrel{n}{\ddot{\Xi}}}{\dot{\sigma}}$ & $\begin{array}{c}\frac{0}{\ddot{m}} \\
\overrightarrow{0}\end{array}$ & $\begin{array}{l}\stackrel{N}{\sim} \\
\stackrel{\leftrightarrow}{=}\end{array}$ & 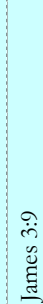 \\
\hline 397 & conf. & 3.7 .12 & WSA & $\mathrm{I} / 1$ & 1 & & & & & & & & & & & & & & & & & & & \\
\hline 397 & conf. & 6.3 .4 & WSA & $\mathrm{I} / 1$ & 1 & & & & & & & & & & & & & & & & & & & \\
\hline 397 & conf. & 6.11 .18 & WSA & $\mathrm{I} / 1$ & 1 & & & & & & & & & & & & & & & & & & & \\
\hline 397 & conf. & 7.1 .1 & W'A & I 1 & 1 & & & & & & & & & & & & & & & & & & & \\
\hline 397 & conf. & 7.7 .11 & WA & $\mathrm{I} / 1$ & & & & & & & & & & & & & & & & & & & & \\
\hline 397 & conf. & 7.9 .15 & WSA & I 1 & 1 & & & & & & & & & & & & & & & & & & & \\
\hline 397 & conf. & 11.9 .11 & WSA & $\mathrm{I} / 1$ & & & & & & & & & & & & & & & & & & & & \\
\hline 397 & conf. & 13.11 .12 & WSA & $\mathrm{I} / 1$ & & & & & & & & & & & & & & & & & & & & \\
\hline 397 & conf. & 13.15.18 & WSA & $\mathrm{I} / 1$ & & & & & & & & & & & & & & & & & & & 1 & \\
\hline 397 & conf. & 13.22 .32 & W'A & $\mathrm{I} / 1$ & 1 & & & & & & & & & & & & & & & & & 2 & & \\
\hline 397 & conf. & 13.24 .35 & WSA & I $1 / 1$ & 1 & & & & & & & & & & & & & & & & & & & \\
\hline 397 & conf. & 13.32 .47 & WSA & $\mathrm{I} / 1$ & 1 & & & & & & & & & & & & & & & & & & & \\
\hline 397 & s. 27 & 27 & WSA & IIII $/ 2$ & & & & & & & & & & & & & & & & & & & 1 & \\
\hline 397 & 38 & 38 & WSA & III $/ 2$ & & & & & & & & & & & & & & & & & & & 1 & \\
\hline 397 & 60 & 60.2 .2 & WSA & IIII/3 & 1 & & & & & & & & & & & & & & & & & & & \\
\hline 397 & s. 72 & 72 & WSA & IIII/11 & & & & & & & 1 & & & & & & & & & & & & & \\
\hline 397 & s. $90 \mathrm{~A}$ & $90 \mathrm{~A}$ & WA & IIII/11 & & & & & & & & & & & & & & & & $\cdots$ & & & & \\
\hline 397 & s. 160 & 160 & WSA & iIII/5 & & & & & & & & & & & & & 1 & & & & & & & \\
\hline 397 & 1s. 178 & & WSA & IIII $/ 5$ & & & & & & & & & & & & & & & & & & & 1 & \\
\hline 397 & s. $308 \mathrm{~A}$ & $308 \mathrm{~A}$ & WSA & IIII/9 & & & & & & & 1 & & & & & & & & & & & & & \\
\hline 399 & cat. rud. & 18.29 & Canning & & 1 & & & & & & & & & & & & & & & & & & & \\
\hline $399^{\circ}$ & cat. rud. & 22.39 & Canning & & 1 & & & & & & & & & & & & & & & & & & & \\
\hline 400 & en. Ps. 84 & 84.9 & WSA & III $/ 18$ & & & & & & & & & & & & & & & & & & & 1 & \\
\hline 400 & en. Ps. 97 & $97.1,3$ & $\mathrm{WSA}$ & IIII $/ 18$ & 1 & & & & & & & & & & & & & & & & & & 1 & \\
\hline 400 & en. Ps. 115 & 115.8 & WSA & IIII/19 & & & & & & & 1 & & & & & & & & & & & & & \\
\hline 400 & qu. ev. & 1.9 .94 & CCL & $44 \mathrm{~B}$ & 1 & & & & & & & & & & & & & & & & & & & \\
\hline 400 & s. 259 & 259.2 & WSA & IIII/7 $/ 7$ & 1 & & & & & & & & & & & & & & & & & & & \\
\hline 400 & s. 43 & 43.2 .3 & W'SA & IIII $/ 2$ & 1 & & & & & & & & & & & & & & & & & & & \\
\hline 401 & en. Ps. 36 & $36(2) .8$ & WSA & IIII $/ 16$ & & & & & & & & & & & & & & & & & & & 1 & \\
\hline 401 & en. Ps. 40 & 40.3 & WSA & IIII/ 16 & 1 & & & & & & & & & & & & & & & & & & & \\
\hline 401 & ep. 55 [inq. Ian.] & 55.11 .20 & $\mathrm{WSA}$ & III $/ 1$ & & & & & & & & & & & & & & & & & & & & \\
\hline 401 & ep. 64 & 64.1 & WSA & III/1 & & & & & & & & & & & & & & & & & & & 1 & \\
\hline 401 & op. mon. & $31-32$ & FOTC & 16 & & & & & & & & & & 2 & & & & & 1 & 1 & & 1 & & \\
\hline 401 & s. $229 \mathrm{~V}$ & & IWSA & IIII/6 & & & & & & & & & & & & & & & & & & & & \\
\hline 401 & s. $229 \mathrm{~W}$ & & WSA & IIII $/ 6$ & 1 & & & & & & 1 & & & & & & & & & & & & & \\
\hline 401 & s. 24 & 24.3 & WSA & IIII $/ 2$ & 1 & & & & & & & & & & & & & & & & & & & \\
\hline 401 & s. 288 & & WSA & IIII $/ 8$ & & & & & & & & & & & & & & & & & & & 1 & \\
\hline 401 & $305 A$ & & WSA & iiil $/ 8$ & & & & & & & & & & & & & & & & & & & 1 & \\
\hline 401 & 47 & 47.4 .5 & WSA & $\mathrm{IIII} / 2$ & & & & & & & & & & & & & & & & & & & & \\
\hline 401 & Trin. & 1.14 & WSA & $\mathrm{I} / 5$ & 1 & & & & & & & & & & & & & & & & & & & \\
\hline 401 & Trin. & 1.17 & WSA & $\mathrm{I} / 5$ & & & & & & & & & & & & & & & & & & & 1 & \\
\hline 401 & Trin. & 1.24 & WSA & $\mathrm{I} / 5$ & & & & & & & & & & & & & & & & & 0 & & & \\
\hline 403 & en. Ps. 32 & $32(2) .3-4,11$ & $\mathrm{WSA}$ & IIII $/ 15$ & 2 & & & & & & & & & & & & & & & & & & & \\
\hline 403 & en. Ps. 42 & 42.6 & WSA & IIII $/ 16$ & 1 & & & & & & & & & & & & & & & & & & & \\
\hline 403 & en. Ps. 57 & 57.1 & WSA & IIII/ $/ 17$ & 1 & & & & & & & & & & & & & & & & & & & \\
\hline 403 & en. Ps. 57 & $57.10,11$ & W'SA & IIII/ 17 & & & & & & & 1 & & & & & & & & & & & 1 & & \\
\hline 403 & en. Ps. 99 & 99.5 & WSA & IIII/19 & 1 & & & & & & & & & & & & & & & & & & & \\
\hline 403 & en. Ps. 147 & 147.7 & WSA & IIII/20 & 1 & & & & & & & & & & & & & & & & & & & \\
\hline 403 & en. Ps. 99 & 99 & $\mathrm{WSA}$ & IIII/19 & & & & & & & & & & & & & & & 1 & & & & & \\
\hline 403 & s. $360 A$ & & WSA & III $/ 11$ & & & & & & & & & & & & & & & & & & & & \\
\hline 404 & c. Fel. & 1.12 & WSA & $\mathrm{I} / 19$ & & & & & & & & & & & & & & & & & & & 1 & \\
\hline 404 & c. Fel. & 2.2 & WSA & $\mathrm{I} / 19$ & & & & & & & & & & & & & & 0 & & & & & & \\
\hline 404 & Een. Ps. 75 & 75.3 & WSA & IIII $/ 18$ & 1 & & & & & & & & & & & & & & & & & & & \\
\hline 404 & en. Ps. 83 & $83.1,8$ & WSA & IIII/18 & & & & & & & & & 1 & & & & & & & & & 1 & 1 & \\
\hline 404 & en. Ps. 86 & 86.9 & WSA & IIII $/ 18$ & & & & & & & & & & & & & & & & & & & 1 & \\
\hline 404 & s. $159 B$ & & WSA & $\mathrm{IIII} / 11$ & 1 & & & & & & & & & & & & & & & & & & & \\
\hline 404 & s. 198 & & WSA & IIII $/ 11$ & & & & & & & & & & & & & & & & & & & & \\
\hline 404 & s. $23 B$ & & WSA & IIII/11 & & & & & & & & & & & & & & & & & & & & \\
\hline 404 & s. $360 B$ & & WSA & IIII/11 & 1 & & & & & & & & & & & & & & & & & & & \\
\hline 404 & 55 & 55.3 .3 & WSA & $\mathrm{IIII} / 3$ & 1 & & & & & & & & & & & & & & & & & & & \\
\hline 405 & . 2229 & & WSA & IIII $/ 6$ & 1 & & & & & & & & & & & & & & & & & & & \\
\hline 405 & s. $335 \mathrm{C}$ & & WSA & IIII $/ 9$ & 1 & & & 1 & & & & & & & & & & & & & & & & \\
\hline 405 & s. $53 \mathrm{~A}$ & & WSA & IIII/3 $/ 3$ & 1 & & & 1 & & & & & & & & & & & & & & & & \\
\hline 406 & ep. Jo. & 1.1 & WSA & IIII/14 & & & & & & & & & & & & & & & & & & 1 & & \\
\hline 406 & ep. Jo. & 2.1 & WSA & III/ $/ 14$ & & & & & & & & & & & & & & & & & & & & \\
\hline 406 & ep. Jo. & 8.6 & WSA & III $/ 14$ & 1 & & & & & & & & & & & & & & & & & & & \\
\hline 406 & ep. Jo. & 9.3 & WSA & III $/ 14$ & 1 & & & & & & & & & & & & & & & & & & & \\
\hline 406 & ep. Jo. & 1.4 & WSA & IIII/14 & & & & & & & & & & & & & & & & & & & 1 & \\
\hline
\end{tabular}


Appendix A: References to the image of God in Augustine's writings

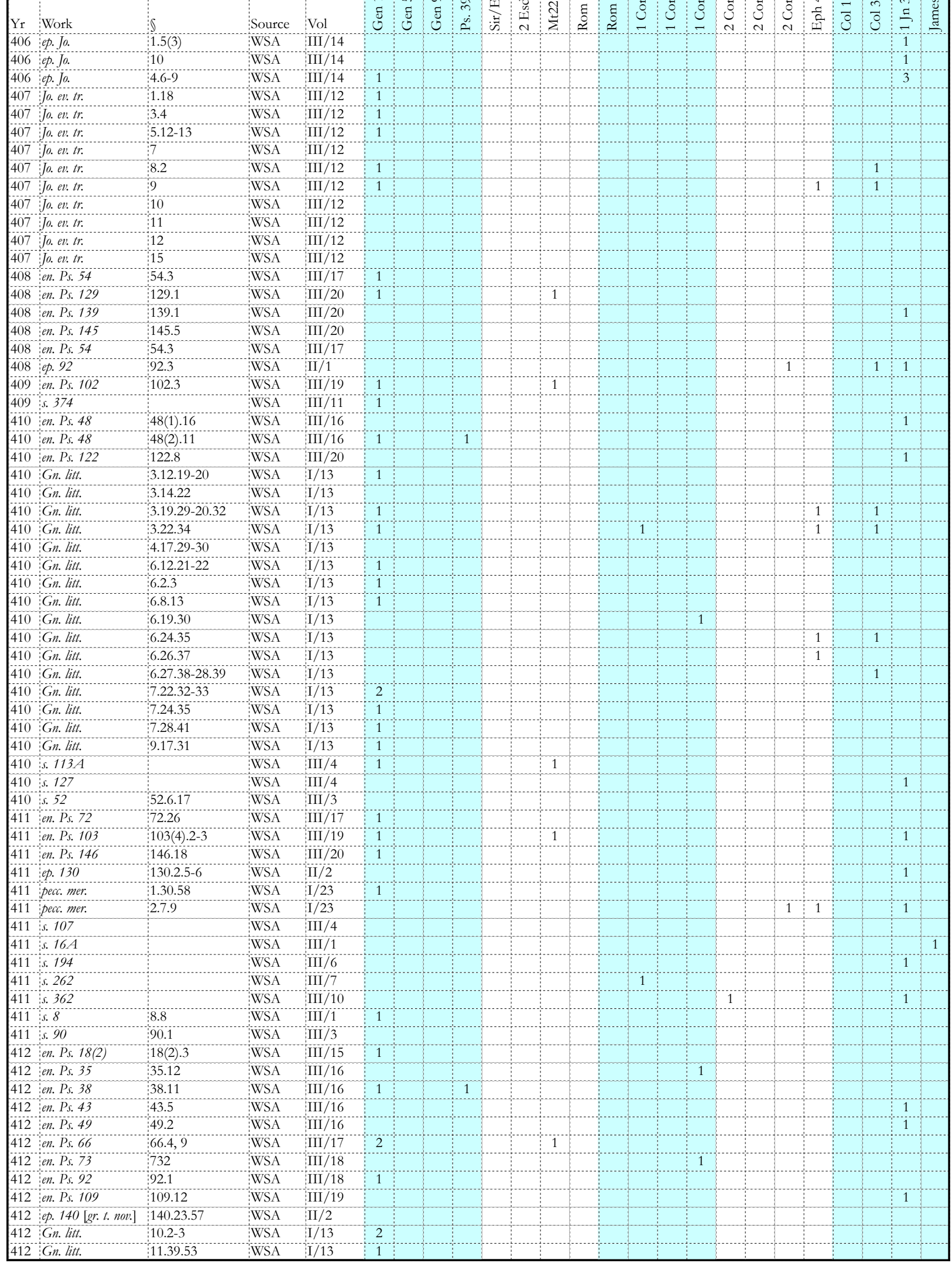


Appendix A: References to the image of God in Augustine's writings

\begin{tabular}{|c|c|c|c|c|c|c|c|c|c|c|c|c|c|c|c|c|c|c|c|c|c|c|c|c|}
\hline $\mathrm{Yr}$ & Work & is & Source & Vol & 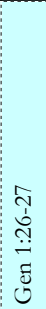 & $\begin{array}{l}m \\
\ddot{\ddot{n}} \\
\tilde{J} \\
\tilde{v}\end{array}$ & 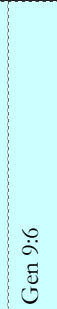 & 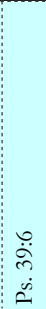 & 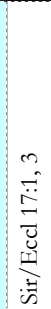 & 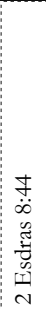 & 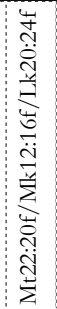 & 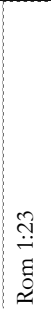 & 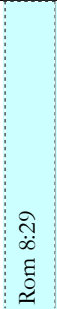 & $\begin{array}{l}\stackrel{\mathscr{J}}{\Xi} \\
\stackrel{0}{0}\end{array}$ & $\begin{array}{c}\frac{v}{0} \\
\ddot{n} \\
\vec{b} \\
-\end{array}$ & 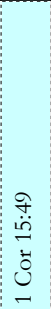 & $\begin{array}{c}\infty \\
\ddot{\ddot{m}} \\
\vec{b} \\
v\end{array}$ & 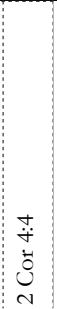 & 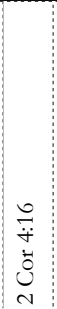 & 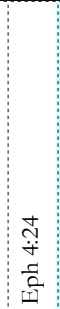 & $\mid$\begin{tabular}{l|}
$\stackrel{n}{\ddot{I}}$ \\
$\overrightarrow{0}$ \\
$\dot{0}$
\end{tabular} & $\frac{0}{\ddot{0}}$ & $\begin{array}{l}\stackrel{\sim}{\rightleftharpoons} \\
\stackrel{\Xi}{=}\end{array}$ & 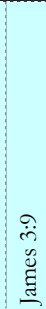 \\
\hline 412 & Gn. litt. & 11.42 .58 & WA & $\mathrm{I} / 13$ & & & & & & & & & & 1 & & & & & & & & & & \\
\hline 412 & Gn. litt. & 12.7 .18 & WSA & $\mathrm{I} / 13$ & & & & & & & & & & & & & & & & 1 & & 1 & & \\
\hline 412 & Gn. litt. & 12.31 .59 & WSA & $\mathrm{I} / 13$ & 1 & & & & & & & & & & & & & & & & & & & \\
\hline 412 & 212 & & WSA & iii $/ 6$ & & & & & & & & & & & & & & & & 1 & & & & \\
\hline 412 & spir et litt. & 22.37 & WSA & $\mathrm{I} / 23$ & & & & & & & & & & & & & & & 1 & & & 1 & 2 & \\
\hline 412 & spir et litt. & $27.48-28.49$ & WSA & $1 / 23$ & & & & & & & & & & & & & & & 1 & & & & & \\
\hline 412 & Trin. & 2.28 & WSA & $\mathrm{I} / 5$ & & & & & & & & & & & & & & & & & & & 1 & \\
\hline 412 & Trin. & 4.5 & WSA & $\mathrm{I} / 5$ & & & & & & & & & & & & & & & 1 & & & & 1 & \\
\hline 412 & Trin. & 4.7 & WSA & $\mathrm{I} / 5$ & 1 & & & & & & & & & & & & & & & & & & & \\
\hline 413 & ep. $14>$ [vid. Deo] & 147.19 .46 & WSA & $\mathrm{II} / 2$ & 1 & & & & & & & & & & & & 1 & & 2 & 1 & & 2 & 3 & \\
\hline 413 & ep. 148 & 148.2 .78 & WSA & III $/ 2$ & & & & & & & & & & & & & 1 & & & & & & 1 & \\
\hline 413 & f. et op. & 6.9 & WSA & $\mathrm{I} / 8$ & & & & & & & & & & & & & & & & & & 1 & & \\
\hline 413 & s. $229 \mathrm{E}$ & & $\mathrm{WSA}$ & iiii $/ 6$ & & & & & & & & & 1 & & & & & & & & & & & \\
\hline 413 & 5.23 & & WSA & $\mathrm{III} / 2$ & & & & & & & & & & & & & & & & & & & 1 & \\
\hline 413 & s. 264 & & $\mathrm{WSA}$ & iIII/7 & & & & & & & & & & & & & & & & & & & 1 & \\
\hline 413 & s. 53 & & WSA & IIII/3 & & & & & & & & 1 & & & & & & & & & & & & \\
\hline 414 & en. Ps. 34 & $34(2) .6$ & $\mathrm{WSA}$ & IIII $/ 16$ & & & & & & & & & & & & & & & & & & & & \\
\hline 414 & en. Ps. 70 & $70(1) .2$ & $\mathrm{WSA}$ & iIII/17 & & & & & & & & & & & & 1 & & & & & & & & \\
\hline 414 & en. Ps. 70 & $70(2) .6$ & WSA & IIII/17 & 1 & & & & & & & & & & & & & & & & & & & \\
\hline 414 & ep. 205 & 205.12 & $\mathrm{WSA}$ & III $/ 3$ & & & & & & & & & & & & 1 & & & & & & & & \\
\hline 414 & Io. ev. tr. & 18.1 & WSA & IIII/12 & & & & & & & & & & & & & & & 1 & & & & & \\
\hline 414 & Io.ev.tr. & 19 & WSA & iII $/ 12$ & & & & & & & & & & & & & & & & & & & & \\
\hline 414 & Io. ev. tr. & 23.1 & WSA & III $/ 12$ & 1 & & & & & & & & & & & & & & & & & & & \\
\hline 414 & Io. ev. tr. & 24 & $\mathrm{WSA}$ & $\mathrm{III} / 12$ & & & & & & & & & & & & & & & & & & & & \\
\hline 414 & Io. ev. tr. & 36 & WSA & IIII/12 & & & & & & & & & & & & & & & & & & & & \\
\hline 414 & Io eve tr. & 40.9 & WSA & IIII/12 & & & & & & & 1 & & & & & & & & & & & & 1 & \\
\hline 414 & Io. ev. tr. & 41.2 & FOTC & 88 & & & & & & & 1 & & & & & & & & & & & & & \\
\hline 414 & Io. ev. tr. & 44.1 & FOTC & 88 & & & & & & & & & & & & & & & & & & & & \\
\hline 414 & Io. ev. tr. & 45.12 & FOTC & 88 & & & & & & & & & 1 & & & & & & & & & & & \\
\hline 414 & Io. ev. tr. & 48.6 & FOTC & 88 & & & & & & & & & 1 & & & & & & & & & & & \\
\hline 414 & Io. ev. tr. & 53.12 & FOTC & 88 & & & & & & & & & & & & & & & & & & & & \\
\hline 414 & Io. ev. tr. & 30.7 & WSA & IIII/12 & & & & & & & & & & & & & & & & & & 1 & & \\
\hline 414 & Io. ev. tr. & $34.3-4,9$ & WSA & iIII/12 & 1 & & & & & & & & & & 1 & & & & & & & & 1 & \\
\hline 414 & Io. ev. tr. & 35.9 & WSA & III/ 12 & & & & & & & & & & & & & & & & & & & 1 & \\
\hline 414 & Trin. & 7.2 & WA & $\mathrm{I} / 5$ & & & & & & & & & & & & & & & & & & & & \\
\hline 414 & Trin. & 7.5 & WSA & I/5 & & & & & & & & & & & & & & & & & & & & \\
\hline 414 & Trin. & 7.12 & WA & $\mathrm{I} / 5$ & 1 & & & & & & & & & 1 & & & & & & & & 1 & & \\
\hline 414 & Trin. & 9.17 & WSA & I/5 & 1 & & & & & & & & & & & & & & & & & 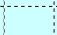 & & \\
\hline 414 & Trin. & 11.1 & WSA & $\mathrm{I} / 5$ & & & & & & & & & & & & & & & 1 & & & 1 & & \\
\hline 414 & Trin. & 11.5 .8 & $\mathrm{WSA}$ & I/5 & 1 & & & & & & & & & & & & & & & & & & & \\
\hline 415 & c. Prisc. & 2.2 & WSA & $\mathrm{I} / 18$ & & & & & & & & & & & & & & & & & & & & \\
\hline 415 & civ. & 8.1 & WSA & $\mathrm{I} / 6$ & & & & & & & & 1 & & & & & & & & & & & & \\
\hline 415 & civ. & 9.17 & WSA & $1 / 6$ & & & & & & & & & & & & & & & & & & & & \\
\hline 415 & civ. & 9.18 & WA & $\mathrm{I} / 6$ & & & & & & & & & & & & & & & & & & & & \\
\hline 415 & en. Ps. 59 & 59.2 & $\mathrm{WSA}$ & iIII/17 & & & & & & & & & & & & 1 & & & & & & & & \\
\hline 415 & en. Ps. 67 & 67.44 & W'A & IIII/17 & & & & & & & & & & & & & & & & & & & 1 & \\
\hline 415 & en. Ps. 77 & 77.45 & WSA & :III/18 & 1 & & & & & & & & & & & & & & & & & & & \\
\hline 415 & en. Ps. 136 & 136.18 & WSA & III/ $/ 20$ & & & & & & & & & & & & 1 & & & & & & & & \\
\hline 415 & en. Ps. 138 & 138.14 & WSA & IIII $/ 20$ & 1 & & & & & & 1 & & & & & & & & & & & & & \\
\hline 415 & $e p .120$ & $120.2-4$ & WSA & $\mathrm{II} / 2$ & & & & & & & & & & & & & & & & & & & & \\
\hline 415 & ep. 169 & $169.1 .2,2.6$ & WAA & $\mathrm{II} / 3$ & & & & & & & & & & & & & & & & & & & & \\
\hline 415 & nat. et gr. & 15.16 & $\mathrm{WSA}$ & $\mathrm{I} / 23$ & & & & & & & & & & & & & & & & & & & & 1 \\
\hline 415 & perf. iust. & $3.8,18.39$ & WA & $\mathrm{I} / 23$ & & & & & & & & & & & & & & & 3 & & & & 3 & \\
\hline 416 & en. Ps. 61 & 61.7 & WSA & IIII/17 & & & & & & & & & & & & & & & & & & 1 & & \\
\hline 416 & gest. Pel. & $3.7,30.55$ & WSA & $\mathrm{I} / 23$ & & & & & & & & & 1 & & & & & & & & & & 1 & \\
\hline 416 & s. 125 & 125.4 & $\mathrm{WSA}$ & $\mathrm{III} / 4$ & & & & & & & & & & & & & & & & & & 1 & & \\
\hline 416 & s. 169 & & WA & $\mathrm{III} / 5$ & & & & & & & & & & & & & & & & & & & 1 & \\
\hline 416 & s. 21 & & $\mathrm{WSA}$ & $\mathrm{iII} / 2$ & & & & & & & & & & & & & & & & & & & 1 & \\
\hline 417 & ep. 185 [correct.] & 185 & $\mathrm{WSA}$ & III $/ 3$ & & & & & & & & & & & & & & & & & & & & \\
\hline 417 & ep. 186 & 186.25 & WSA & $\mathrm{II} / 3$ & & & & & & & & & 1 & & & & & & & & & & & \\
\hline 417 & ep. 189 & 189.3 & WA & III $/ 3$ & & & & & & & & & 1 & & & & & & & & & & & \\
\hline 417 & praes Dei & 187 & WSA & $\mathrm{II} / 3$ & & & & & & & & & $\sim$ & & 1 & 1 & & & & & & & & \\
\hline 417 & s. 126 & 126.9 .11 & WSA & IIII $/ 4$ & 1 & & & & & & & & & & & & & & & & & & & \\
\hline 417 & 26 & $26.1-6$ & $\mathrm{WSA}$ & III $/ 2$ & 1 & & & & & & & & & & & & & & & & & & & \\
\hline 418 & c. s. Arrian. & 16 & $\mathrm{WSA}$ & $\mathrm{I} / 18$ & 1 & & & & & & & & & & & & & & & & & & & \\
\hline 418 & civ. & 11.2 & WSA & $\mathrm{I} / 7$ & 1 & & & & & & & & & & & & & & & & & & & \\
\hline 418 & civ. & $11.26-28$ & WA & $\mathrm{I} / 7$ & & & & & & & & & & & & & & & & & & 2 & & \\
\hline 418 & iviv. & 12.24 & $\mathrm{WSA}$ & $\mathrm{I} / 7$ & 1 & & & & & & & & & & & & & & & & & & & \\
\hline
\end{tabular}


Appendix A: References to the image of God in Augustine's writings

\begin{tabular}{|c|c|c|c|c|c|c|c|c|c|c|c|c|c|c|c|c|c|c|c|c|c|c|c|c|}
\hline $\mathrm{Yr}$ & Work & is & Source & Vol & 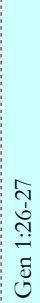 & $\begin{array}{l}m \\
\ddot{n} \\
\tilde{E} \\
0\end{array}$ & $\begin{array}{l}\stackrel{0}{0} \\
\ddot{\Xi} \\
\tilde{U}\end{array}$ & $\begin{array}{l}\infty \\
\stackrel{d}{0} \\
\infty \\
\infty\end{array}$ & 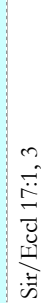 & 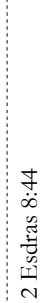 & 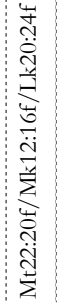 & 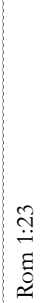 & 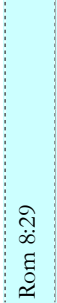 & $\begin{array}{l}\stackrel{\nearrow}{=} \\
\stackrel{0}{0}\end{array}$ & $\begin{array}{c}\frac{a}{3} \\
\overrightarrow{\vec{b}} \\
\dot{b}\end{array}$ & 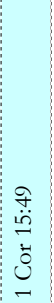 & $\begin{array}{c}\infty \\
\ddot{\ddot{m}} \\
\vec{b} \\
v\end{array}$ & 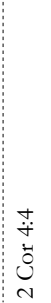 & $\begin{array}{c}0 \\
\ddot{+} \\
\dot{U} \\
v\end{array}$ & 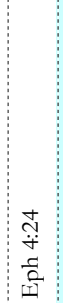 & 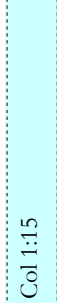 & $\frac{0}{\ddot{0}}$ & $\begin{array}{l}\stackrel{N}{n} \\
\Xi \\
\Xi\end{array}$ & 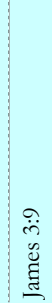 \\
\hline 418 & civ. & 13.23 & WSA & $\mathrm{I} / 7$ & & & & & & & & & 1 & & & 1 & & & & & & & & \\
\hline 418 & civ. & 13.24 & WSA & $\mathrm{I} / 7$ & & & & & & & & & & & & 1 & & & 1 & & & & & \\
\hline 418 & civi & 14.15 & WSA & $\mathrm{I} / 7$ & 1 & & & & & & & & & & & & & & & & & & & \\
\hline 418 & civ. & 15.21 & $\mathrm{WSA}$ & I & & 1 & & & & & & & & & & & & & & & & & & \\
\hline 418 & civ. & 16.6 & WSA & $\mathrm{I} / 7$ & 1 & & & & & & & & & & & & & & & & & & & \\
\hline 418 & civ. & 17.5 & $\mathrm{WSA}$ & $1 / 7$ & 1 & & & & & & & & & & & & & & & & & & & \\
\hline 418 & civi. & 18.51 & WSA & $\mathrm{I} / 7$ & & & & & & & & & 1 & & & & & & & & & & & \\
\hline 418 & en. Ps. 118 & $118(08) .1$ & WSA & IIII 19 & & & & & & & & & 1 & & & & & & & & & & & \\
\hline 418 & en. Ps. 118 & $118(18) .4$ & WSA & III $/ 19$ & & & & & & & & & & & & & & & & & & & & \\
\hline 418 & s. 117 & $117.9 .12,10.15$ & WSA & IIII/4 & 1 & & & & & & & & & & & & & & & & & & 1 & \\
\hline 418 & s. 13 & 13.3 .4 & $\mathrm{WSA}$ & iii $/ 1$ & & & & & & & 1 & & & & & & & & & & & & & \\
\hline 418 & (s. 49 & & $\mathrm{WSA}$ & $\mathrm{III} / 2$ & & & & & & & & & & & & & & & & & & & 1 & \\
\hline 419 & an. et or. & 4.14 .20 & $\mathrm{WSA}$ & I 23 & & & & & & & & & & & & & & & 1 & & & & & \\
\hline 419 & c. adv leg. & 1.6 .9 & WSA & $\mathrm{I} / 18$ & & & & & & & & & & & & & & & & & & & & \\
\hline 419 & c. adv leg. & 2.7 .29 & $\mathrm{WSA}$ & $\mathrm{I} / 18$ & & & & & & & & & & & & & & 1 & & & & & & \\
\hline 419 & Io. ev. tr. & 20 & WSA & III/12 & 1 & & & & & & & & & & & & & & & & & & & \\
\hline 419 & Io. ev. tr. & 65.1 & FOTC & 90 & & & & & & & & & & & & & & & & & & 1 & & \\
\hline 419 & Io. ev. tr. & 69.4 & FOTC & 90 & 1 & & & & & & & & & & & & & & & & & & & \\
\hline 419 & Io. ev. tr. & 72.3 & FOTC & 90 & & & & & & & & & 1 & & & & & & & & & & & \\
\hline 419 & Io. ev. tr. & 75.4 & FOTC & 90 & & & & & & & & & & & & & & & & & & & 1 & \\
\hline 419 & Io. ev. tr. & 76.5 & FOTC & 90 & 1 & & & & & & & & & & & & & & & & & & & \\
\hline 419 & Io.ev.tr. & 77.3 & FOTC & 90 & & & & & & & & & & & & & & & & & & & 1 & \\
\hline 419 & Io. ev. tr. & 101.5 & FOTC & 90 & & & & & & & & & & & & & & & & & & & 1 & \\
\hline 419 & Io. ev. tr. & 102.3 & FOTC & 90 & & & & & & & & & & & & & & & & & & & 1 & \\
\hline 419 & Io. ev. tr. & 105.7 & FOTC & 90 & & & & & & & & & 1 & & & & & & & & & & & \\
\hline 419 & Io. ev. tr. & 106.4 & FOTC & 90 & & & & & & & & & & & & & & & & & & & & \\
\hline 419 & Io. ev. tr. & $111.2(4)$ & FOTC & 90 & & & & & & & & & & & & & & & & & & & 1 & \\
\hline 419 & Io. ev. tr. & 124.6 & FOTC & 92 & & & & & & & & & & & & & & & & & & & 1 & \\
\hline 419 & oco. & 1.2 & $\mathrm{CCL}$ & 33 & 1 & & & & & & & & & & & & & & & & & & & \\
\hline 419 & nupt. et conc. & & WSA & $\mathrm{I} / 24$ & 1 & & & & & & & & & & & & & & & & & & & \\
\hline 419 & $q u$. & 5.4 & CCL & 33 & 1 & & & & & & & & & & & & & & & & & & & \\
\hline 419 & s. 158 & & WSA & IIII $/ 5$ & & & & & & & & & & & & & & & 0 & & & & 0 & \\
\hline 419 & Trin. & 12.1 & WSA & I/ 5 & 1 & & & & & & & & & 1 & & & & & & & & & & \\
\hline 419 & Trin. & 12.6 & WSA & I/5 & 2 & & & & & & & & & & & & & & & & & & & \\
\hline 419 & Trin. & 12.7 & WSA & $1 / 5$ & 1 & & & & & & & & & & & & & & & & & & & \\
\hline 419 & Trin. & 12.8 & WSA & I/5 & 1 & & & & & & & & & & & & & & & & & & & \\
\hline 419 & Trin. & 12.9 & WA & $\mathrm{I} / 5$ & & & & & & & & & & 1 & & & & & & & & & & \\
\hline 419 & Trin. & 12.12 & $\mathrm{WSA}$ & I/5 & & & & & & & & & & 1 & & & & & & 1 & & 1 & & \\
\hline 419 & Trin. & 12.21 & WSA & $\mathrm{I} / 5$ & & & & & & & & & & 1 & & & & & & & & & & \\
\hline 419 & Trin. & 12.22 & WSA & I/5 & & & & & & & & & & & 1 & & & & & & & & 1 & \\
\hline 419 & Trin. & 13.2 & WSA & $\mathrm{I} / 5$ & & & & & & & & & 1 & & & & & & & & & & & \\
\hline 419 & Trin. & 13.24 & WSA & $\mathrm{I} / 5$ & & & & & & & & 1 & & & & & & & & & & & & \\
\hline 419 & Trin. & 14.6 & WSA & $1 / 5$ & & & & 1 & & & & & & & & & & & & & & & & \\
\hline 419 & Trin. & 14.22 & WSA & $\mathrm{I} / 5$ & & & & & & & & & & & & & & & & 1 & & 1 & & \\
\hline 419 & Trin. & 14.23 & $\mathrm{WSA}$ & $1 / 5$ & & & & & & & & & & & 1 & & 1 & & 1 & 1 & & 1 & 1 & \\
\hline 419 & Trin. & 14.24 & $\mathrm{WSA}$ & $\mathrm{I} / 5$ & & & & & & & & & 1 & & & 1 & & & & & & & & \\
\hline 419 & Trin. & 14.25 & WSA & $1 / 5$ & 1 & & & & & & & & & & & & & & & & & & 1 & \\
\hline 419 & Trin. & 15.2 & WSA & $\mathrm{I} / 5$ & & & & & & & & & & & & & 1 & & & & & & & \\
\hline 419 & Trin. & 15.5 & WSA & I/5 & & & & & & & & & & & & & & & & & & 1 & & \\
\hline 419 & Trin. & 15.14 & WSA & $\mathrm{I} / 5$ & & & & & & & & & & 1 & & & 1 & & & & & & 1 & \\
\hline 419 & Trin. & 15.21 & WAA & $\mathrm{I} / 5$ & & & & & & & & & & & 1 & & & & & & & & 1 & \\
\hline 419 & Trin. & 15.26 & $\mathrm{WSA}$ & I/5 & & & & & & & & & & & & & & & & & & & 1 & \\
\hline 420 & c.ep. Pel. & 2.10 .22 & WA & $\mathrm{I} / 24$ & & & & & & & & & 1 & & & & & & & & & & & \\
\hline 420 & c. ер. Pel. & 3.7 .19 & WSA & I 24 & & & & & & & & & & & & & & & & & & & 1 & \\
\hline 420 & c. mend. & & FOTC & 16 & & & & & & & & & & & & & & & & & & & & \\
\hline 420 & ciiv. & 19.15 & WSA & I/7 & 1 & & & & & & & & & & & & & & & & & & & \\
\hline 420 & civ. & 20.3 & WSA & $\mathrm{I} / 7$ & 1 & & & & & & & & & & & & & & & & & & & \\
\hline 420 & civ. & 21.24 & $\mathrm{WSA}$ & I/7 & & & & & & & & & 1 & & & & & & & & & & & \\
\hline 420 & civ. & 22.12 & WSA & $1 / 7$ & & & & & & & & & 1 & & & & & & & & & & & \\
\hline 420 & civ. & 22.16 & WSA & $\mathrm{I} / 7$ & & & & & & & & & 1 & & & & & & & & & & & \\
\hline $420^{\circ}$ & civ. & 22.17 & WA & I/7 7 & & & & & & & & & 1 & & & & & & & & & & & \\
\hline 420 & civ. & 22.24 & WSA & $\mathrm{I} / 7$ & 1 & & & & & & & & & & & & & & & & & & & \\
\hline 420 & civ. & 22.29 & WSA & $1 / 7$ & & & & & & & & & & & & & 1 & & & & & & & \\
\hline 420 & ep. 174 & 174 & WSA & $\mathrm{II} / 3$ & & & & & & & & & & & & & & & & & & & & \\
\hline $420^{\circ}$ & s. $20 \mathrm{~A}$ & 20.2 & $\mathrm{WSA}$ & iII $/ 2$ & 1 & & & & & & & & & & & & & & & & & & & \\
\hline 420 & s. 9 & $9.8-9$ & WSA & IIII/1 & 1 & & & & & & 1 & & & & & & & & & 1 & & & & \\
\hline 421 & cura mort. & & FOTC & 27 & & & & & & & & & & & & & & & 1 & & & & & \\
\hline 422 & c. Iul. & 1.7 .32 & WSA & $\mathrm{I} / 24$ & 1 & & & & & & & & & & & & & & & . & & & & \\
\hline
\end{tabular}


Appendix A: References to the image of God in Augustine's writings

\begin{tabular}{|c|c|c|c|c|c|c|c|c|c|c|c|c|c|c|c|c|c|c|c|c|c|c|c|c|}
\hline $\mathrm{Yr}$ & Work & s & Source & Vol & 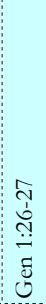 & $\begin{array}{l}\stackrel{n}{\vec{H}} \\
\overrightarrow{\tilde{V}}\end{array}$ & $\begin{array}{l}\stackrel{0}{\circ} \\
\tilde{u} \\
0\end{array}$ & $\begin{array}{l}\stackrel{\circ}{\circ} \\
\stackrel{\infty}{\infty}\end{array}$ & 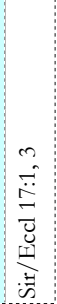 & 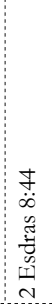 & 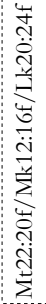 & 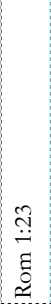 & 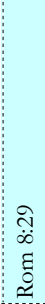 & $\begin{array}{c}\stackrel{\mathscr{ت}}{\vec{b}} \\
\stackrel{0}{0}\end{array}$ & $\underset{\sim}{\stackrel{\vec{\sigma}}{\sigma}}$ & 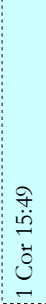 & 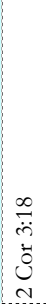 & \begin{tabular}{l}
+ \\
$\dot{+}$ \\
$\dot{0}$ \\
\multirow{2}{*}{}
\end{tabular} & $\begin{array}{l}\stackrel{\mathscr{y}}{\dot{U}} \\
\stackrel{v}{u}\end{array}$ & $\frac{\stackrel{+}{+}}{\stackrel{f}{0}}$ & $\stackrel{\stackrel{n}{ت}}{\stackrel{0}{0}}$ & $\frac{\stackrel{0}{\ddot{~}}}{\dot{0}}$ & $\underset{\stackrel{N}{\rightleftharpoons}}{=}$ & $\begin{array}{l}\text { ले } \\
\text { ్ֶ } \\
\text { हू }\end{array}$ \\
\hline 422 & c. Iul. & 2.1 .3 & WA & II/24 & 1 & & & & & & & & & & & & & & & & & & & \\
\hline 422 & c. Iul. & 2.3 .7 & WSA & II 24 & 1 & & & & & & & & & & & & & & & & & & & \\
\hline 422 & c. Iul. & 3.38 & WSA & $1 / 24$ & 1 & & & & & & & & & & & & & & & & & & & \\
\hline 422 & c. Iul. & 3.3 .9 .10 & WSA & II/24 & 1 & & & & & & & & & & & & & & & & & & & \\
\hline 422 & c. Iul. & 4.3 .15 & WSA & {$[/ 24$} & 1 & & & & & & & & & & & & & & & & & & & \\
\hline 422 & c. Iul. & 4.14 .68 & WSA & $1 / 24$ & 1 & & & & & & & & & & & & & & & & & & & \\
\hline 422 & c. Iul. & 5.1 .4 & WSA & $I / 24$ & 1 & & & & & & & & & & & & & & & & & & & \\
\hline 422 & c. Iul. & 5.4 .14 & WSA & $\mathrm{I} / 24$ & & & & & & & & & 1 & & & & & & & & & & & \\
\hline 422 & c. Iul. & 5.11 .44 & WSA & $\mathrm{I} / 24$ & 1 & & & & & & & & & & & & & & & & & & & \\
\hline 422 & c. Iul. & 5.15 .56 & WSA & $1 / 24$ & 1 & & & & & & & & & & & & & & & & & & & \\
\hline 422 & c. Iul. & 6.4 .10 & INSA & II/24 & 1 & & & & & & & & & & & 1 & & & & & & & & \\
\hline 422 & c. Iul. & 6.926 & WSA & $I / 24$ & & & & & & & & & & & & 1 & & & & & & & & \\
\hline 422 & c. Iul. & 6.10 .32 & WSA & II $/ 24$ & 1 & & & & & & & & & & & & & & & & & & & \\
\hline 422 & c. Iul. & 6.21 .67 & WSA & $\mathrm{I} / 24$ & 1 & & & & & & & & & & & & & & & & & & & \\
\hline 422 & c. Iul. & 6.24 .81 & WSA & II/24 & 1 & & & & & & & & & & & & & & & & & & & \\
\hline 422 & Dulc. qu. & 3.3 & WSA & $\mathrm{I} / 12$ & & & & & & & & & & & & & & & & & & & & \\
\hline 422 & ench. & 27 & WSA & $\mathrm{I} / 8$ & 1 & & & & & & & & & & & & & & & & & & & \\
\hline 424 & 368 & & WSA & III $/ 10$ & 1 & & & & & & & & & & & & & & & & & & & \\
\hline 425 & gr. et lib. arb. & 13.25 & WSA & $1 / 26$ & 1 & & & & & & & & & & & & & & & & & & & \\
\hline 425 & s. 3350 & & WSA & III $/ 9$ & & & & & & & & & & & & & & & & & & & & \\
\hline 425 & s. 398 [symb. cat.] & 1.2 & $\mathrm{WSA}$ & IIII $/ 10$ & 1 & & & & & & & & & & & & & & & & & & & \\
\hline 426 & corrept. & 714 & WSA & II 26 & & & & & & & & & & & & & & & & & & & & $\ldots$ \\
\hline 426 & corrept. & $9.20-23$ & WSA & $I / 26$ & & & & & & & & & 2 & & & & & & & & & & & . \\
\hline 426 & corrept. & 16.49 & WSA & $1 / 26$ & & & & & & & & & 1 & & & & & & & & & & & \\
\hline 426 & doctr Chr & $4.20 .43-22.51$ & WSA & III11 & & & & & & & & & 1 & & & 1 & & & & & & & & ..... \\
\hline 427 & conl. Max. & 1526 & WA & IIII & & & & & & & & & & & & & & & & & 0 & & & . \\
\hline 427. & conl. Max. & $13-14$ & WSA & $I / 18$ & & & & & & & & & & & & & & & & & 0 & & & \\
\hline 427 & Gn. litt: inp. & $16.61-62$ & WSA & 1113 & 1. & & & & & & & & & $\ldots$ & & & & & & & & & & (1" \\
\hline 427 & retr. & $1.16 .61-62$ & WSA & $I / 2$ & & & & & & & & & & & & & & & & & & & & \\
\hline 427 & retr. & 11.17 & WSA & $1: 2$ & 1 & & & & & & & & & & & & & & & & & & & ... \\
\hline 427 & retr: & $1.25(51)$ & WSA & $1 / 2$ & & & & & & & & & & & & & & & & & & & & \\
\hline 427 & retr. & $1.25(67)$ & WSA & {$[1 / 2$} & & & & & & & & & & & & & & & & & & & & $\ldots$ \\
\hline 427 & retr: & $1.25(74)$ & WSA & II/2 & & & & & & & & & & & & & & & & & 0 & & & \\
\hline 427 & retr: & 2.26 & WSA & $I / 2$ & & & & 1 & & & & & & & & & 1 & & & & & & & $\cdots$ \\
\hline 427 & retr: & 2.51 & WSA & $I / 2$ & 1. & & & & & & & & & & & & & & & & & & & \\
\hline 428 & a Max & 2.26 .10 & WSA & III18 & & & & & & & & & & & & & & & & & & & & .. \\
\hline 428 & Max. & 2.26 .2 & WSA & $1 \mathrm{I} 18$ & 1 & & & & & & & & & & & & & & & & & & & \\
\hline 428 & 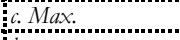 & 29.1 & WSA & 1118 & & & & & & & & & & & & & & & & & & & 1 & $\ldots .$. \\
\hline 428 & baer:............... & 276 & WSA & $1[18$ & 1 & & & & & & & & & & & & & & & & & & & \\
\hline 428 & baer. & $19.49,50,51,54$ & WSA & $I / 18$ & 1 & & & & & & & & & & & & & & & & & & & \\
\hline 429 & adv: Iud. & & FOTC & 27 & & & & & & & & & & & & & & & & & & & & \\
\hline 429 & cill. imp. & 1.5 & WAA & $1 / 25$ & 1 & & & & & & & & & & & & & & & & & & & \\
\hline 429 & c. Iul. imp. & 1.13 & WSA & $I / 25$ & & & & & & & & & & & & & & & & & & & & \\
\hline 429 & c. Imlimp. & 1.37 & WSA & $1 / 25$ & 1 & & & & & & & & & & & & & & & & & & & \\
\hline 429 & c. Iul.imp. & $139-40$ & WSA & $I I 25$ & 1 & & & & & & & & & & & & & & & & & & & $\ldots$ \\
\hline 429 & Ictilimp. & 1.53 & WSA & 1125 & 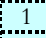 & & & & & & & & & & & & & & & & & & & \\
\hline 429 & o. Iull. imp. & 1.63 & WSA & $1 / 25$ & 1 & & & & & & & & & & & & & & & & & & & \\
\hline 429 & cill. imp. & 1.133 & WSA & $1 / 25$ & & & & & & & & & & & & & & & & & & & & \\
\hline 429 & a I I I imp. & 1.136 & WSA & II 25 & 1 & & & & & & & & & & & & & & & & & & & \\
\hline 429 & inl $i m p$. & 2.3 & WSA & $1 / 25$ & 1 & & & & & & & & & & & & & & & & & & & \\
\hline 429 & c. Iul.imp. & 2.113 & WSA & $1 / 25$ & $1 .$. & & & & & & & & & & & & & & & & & & & \\
\hline 429 & c. IIIL imp. & 3.9 & WSA & $1 / 25$ & 11 & & & & & & & & & & & & & & & & & & & \\
\hline 429 & cill. imp. & $3.44-45$ & WSA & $1 / 25$ & 11 & & & & & & & & & & & & & & & & & & & \\
\hline 429 & a $\operatorname{Imllimp}$. & 3.97 & WSA & $1 / 25$ & 1 & & & & & & & & & & & & & & & & & & & \\
\hline 429 & c...Iul. imp. & 3.109 & WSA & $1 / 25$ & & & & & & & & & & & & & & & & & & & & \\
\hline 429 & cillimp. & 3161 & WSA & $1 / 25$ & $1 .$. & & & & & & & & & & & & & & & & & & & \\
\hline 429 & c. Iul.imp. & 4.4 & WSA & $I / 25$ & 1. & & & & & & & & & & & & & & & & & & & \\
\hline 429 & 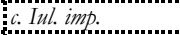 & 4.22 & WISA & $1 / 25$ & & & & & & & & & & & & & & & & & & & & ....... \\
\hline 429 & c. Iul. imp. & 4.26 & WSA & $1 / 25$ & & & & & & & & & & & & & & & & & & & & \\
\hline 429 & c. Iml. imp. & 439 & WSA & 1125 & $1 \ldots$ & & & & & & & & & & & & & & & & & & & \\
\hline 429 & c. Iul. imp. & 4.56 & WSA & $I / 25$ & $1 .$. & & & & & & & & & & & & & & & & & & & \\
\hline 429 & 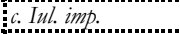 & 4.69 & WSA & $1 / 25$ & & & & & & & & & & & & .... & & & & & & & & \\
\hline 429 & c. Iul.imp. & 4.75 & WSA & $I / 25$ & $1 .$. & & & & & & & & & & & 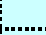 & & & & & & & & \\
\hline 429 & a I I I imp. & 538 & WWA & $1 / 25$ & 1 & & & & & & & & & & & & & & & & & & & \\
\hline 429 & $c \operatorname{lall} i m p$. & 6.2 & WSA & $1 / 25$ & 1 & & & & & & & & & & & & & & & & & & & \\
\hline 429 & allimp. & 6.4 & WSA & $1 / 25$ & & & & & & & & & & & & 1 & & & & & & & & ....... \\
\hline 429 & c. Iul. imp. & 6.5 & WSA & $1 / 25$ & & & & & & & & & & & & & & & & & & & & \\
\hline 429 & c. Iul. imp. & 6.17 & WSA & $I / 25$ & 1 & & & & & & & & & & & & & & & & & & & \\
\hline
\end{tabular}


Appendix A: References to the image of God in Augustine's writings

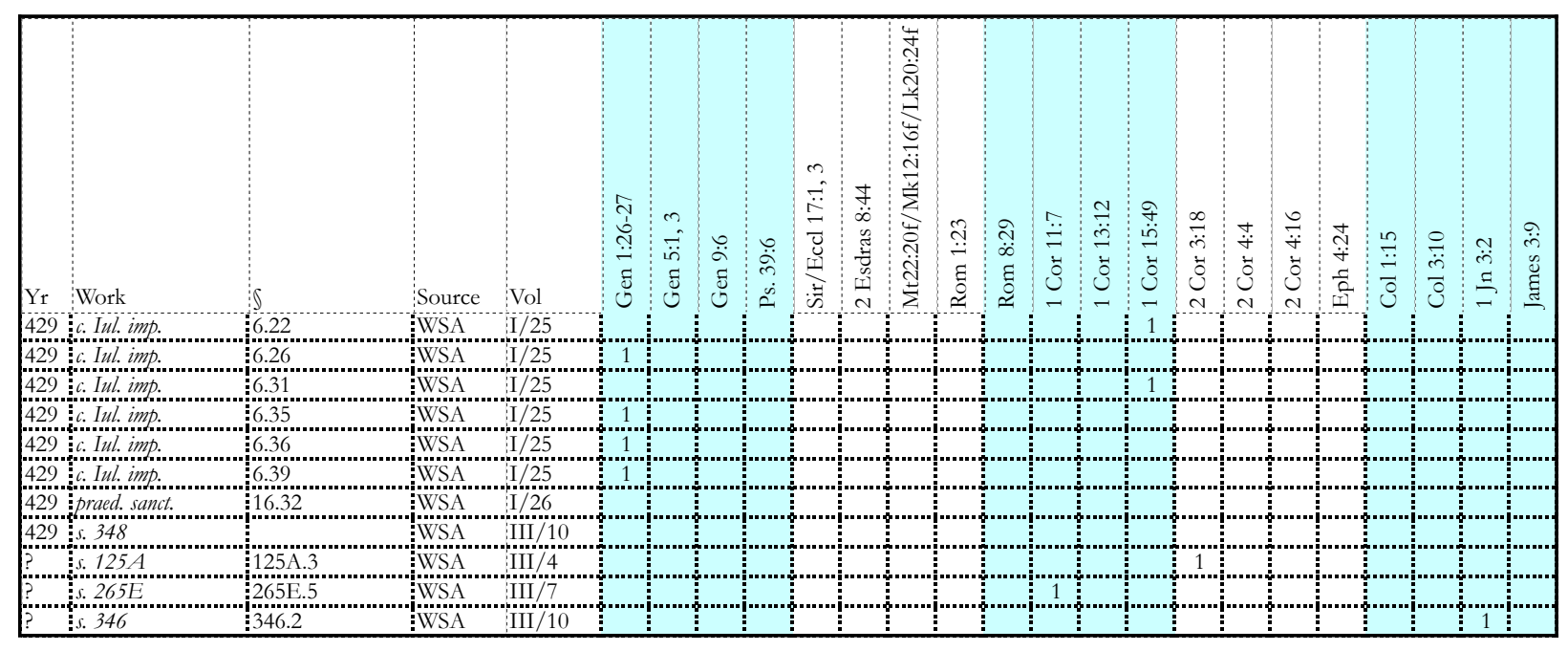




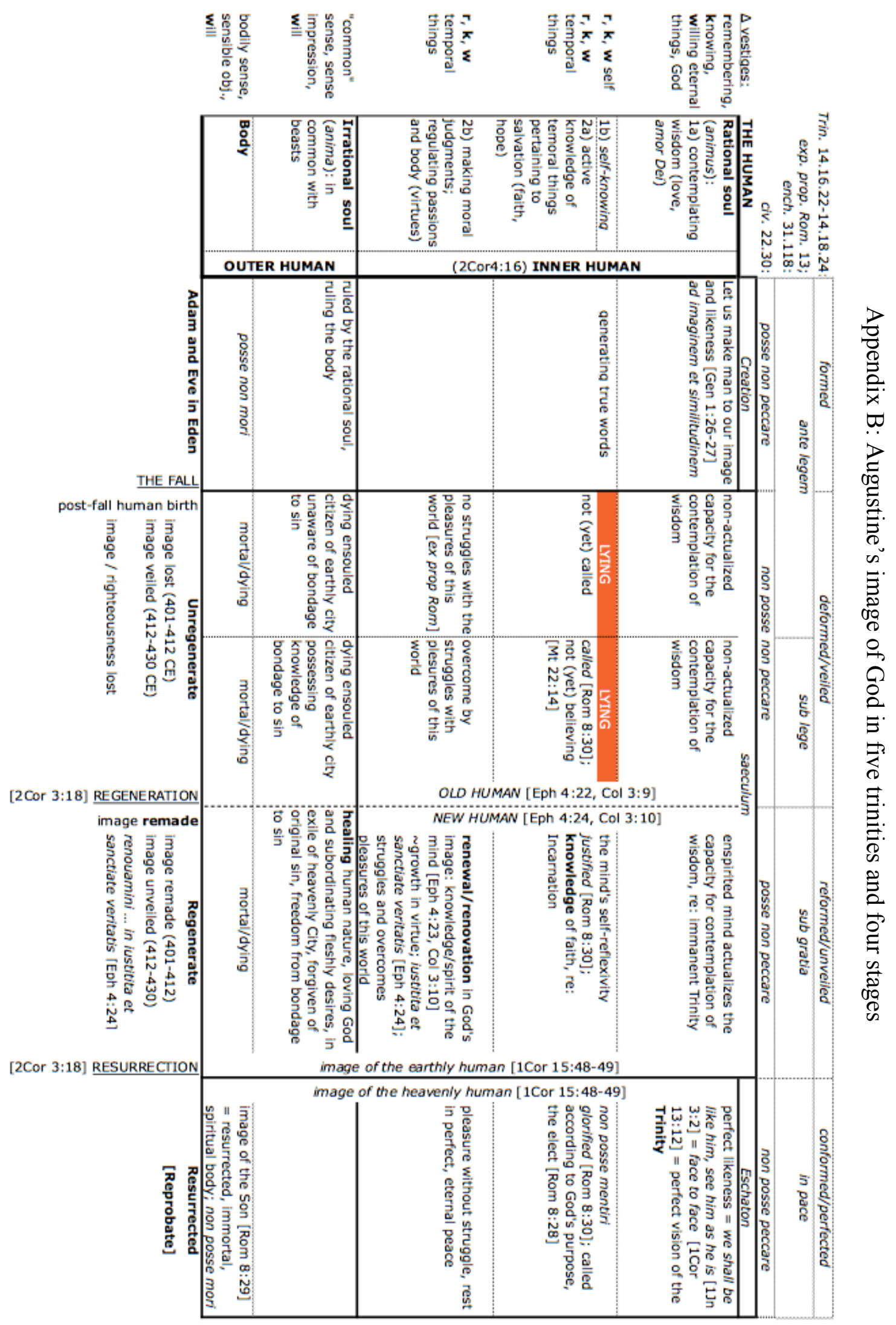


Appendix C: Scriptural texts cited by Augustine in his primary expositions of lying

\begin{tabular}{|c|c|c|c|c|c|c|c|c|c|c|}
\hline $\begin{array}{c}\text { s. Dom. Mon. } 5.37 \\
\text { (394) }\end{array}$ & $\begin{array}{l}\text { en. Ps. } 5.7 \\
\text { (394) }\end{array}$ & mend. & $\S$ & $\begin{array}{c}\text { ep. } 82 \\
(405)\end{array}$ & \multicolumn{2}{|l|}{ c. mend. } & \multicolumn{2}{|c|}{ ench. 5.17-7.22 } & $\underset{(425)}{\text { Trin.XV.8.14 }}$ & $\begin{array}{l}5.26 \\
\S\end{array}$ \\
\hline Gen 3.19 & Ex $1.19-20$ & Gen 18.15 & 5 & Ex 20.17 & Gen $19.5-11$ & 34 & Gen 37.33 & 21 & Prov 30.15 & $\begin{array}{l}-8 \\
-15\end{array}$ \\
\hline Num 30.3 & Wis 1.11 & Gen 19.8 & 10 & Ex 20.17 & Gen 19.8 & 20 & Is 5.20 & 19 & Wis 2.1 & 17 \\
\hline Mt 5.37 & Mt 5.37 & Gen 27.19 & 5 & Ex 20.25 & Gen $20.2,12$ & 23 & $\mathrm{Hb} 2.4$ & 20 & Sir 1.5 & 20 \\
\hline Mt 6.13 & Jn 16.12 & Ex 1.19-20 & 5 & Lv 14.2-32 & Gen $26.7,24$ & 23 & Mt 5.37 & 17 & Sir 23.20 & 23 \\
\hline Rom 1.9 & 1 Cor 3.1 & Ex 20.12 & 36 & 2Sam 11.4-17 & Gen 27.16-19 & 24 & Mt 5.37 & 22 & Sir 37.16 & 20 \\
\hline 1Cor 2.15 & & Ex 20.13 & 23 & Ps 5.7 & Gen 38.14-18 & 30 & Mt 6.12 & 22 & Mt 5.37 & 20 \\
\hline 1 Cor 3.1 & & Ex 20.16 & 6 & Prov 27.6 & Gen 42 & 24 & Acts 12.9 & 19 & Mt 5.37 & 23 \\
\hline 1 Cor 15.31 & & Ex 20.16 & 20 & Jer 31.31 & Ex 1.17-20 & 31 & Acts 12.9 & 21 & Mt 6.8 & 23 \\
\hline 2 Cor 11.31 & & Ex 20.16 & 23 & Mt 5.37 & $\operatorname{Josh} 2,6.25$ & 32 & Rom 1.17 & 20 & Mt 9.2 & 17 \\
\hline Gal 1.20 & & Ps 5.7 & 6 & Mt 7.12 & Judg 9.8-15 & 28 & Rom 8.17 & 22 & Mt 9.3 & 18 \\
\hline & & Ps 5.6,7 & 9 & Mt 22.39 & $1 \mathrm{Kgs} 21.13$ & 24 & Gal 3.11 & 20 & Mt 15.11 & 18 \\
\hline & & Ps 5.7 & 23 & Mt 22.40 & $1 \mathrm{Kgs} 25.22-35$ & 21 & Gal 5.6 & 21 & Mt 15.16 & 18 \\
\hline & & Ps 5.7 & 37 & Mt 26.69-75 & $3 \mathrm{Kgs} / 1 \mathrm{Chr} 21.13$ & 24 & Heb 10.38 & 20 & Mt 15.18 & 18 \\
\hline & & Ps 14.3 & 31 & Mk 1.44 & $4 \mathrm{Kgs} / 2 \mathrm{Chr} 10$ & 3 & & & Lk 5.21 & 17 \\
\hline & & Prov 29.27 & 37 & Jn $1.16,17$ & Ps 5.7 & 1 & & & Lk 12.17 & 17 \\
\hline & & Prov 29.27 & 37 & Jn 5.18 & Ps 6.8 & 21 & & & Jn 1.1 & 19 \\
\hline & & Ezek 16.52 & 7 & Jn 5.46 & Ps 14.3 & 2 & & & Jn 1.1 & 20 \\
\hline & & Wis 1.11 & 6 & Jn 5.6 & Ps 14.3 & 14 & & & Jn 1.3 & 20 \\
\hline & & Wis 1.11 & 9 & In 7.10 & Ps 17.45 & 27 & & & Jn 1.3 & 20 \\
\hline & & Wis 1.11 & 31 & Lk 16.16 & Ps 26.12 & 29 & & & Jn 1.14 & 20 \\
\hline & & Wis 1.11 & 31 & Acts $10.9-16$ & Ps 30.23 & 27 & & & Jn 5.19 & 23 \\
\hline & & Wis 1.11 & 33 & Acts 15.28 & Ps 54.6 & 21 & & & Jn 5.19 & 24 \\
\hline & & Wis 1.6-11 & 31 & Acts 16.3 & Ps 83.5 & 33 & & & Jn 13.21 & 19 \\
\hline & & Sir 7.14 & 34 & Acts 18.18 & Ps 115.11 & 40 & & & Acts 6.7 & 20 \\
\hline & & Mt 5.34 & 28 & Acts $21.20-25$ & Ps 115.15 & 34 & & & Rom 10.17 & 20 \\
\hline & & Mt 5.34 & 37 & Acts 21.26 & Ps 118.142 & 31 & & & 1 Cor 11.7 & 14 \\
\hline & & Mt 5.37 & 6 & Rom 3.2 & Prov 29.27 & 33 & & & 1 Cor 13.12 & 14 \\
\hline & & Mt 5.37 & 28 & Rom 3.19 & Prov 29.27 & 40 & & & 1 Cor 13.12 & 15 \\
\hline & & Mt 5.39 & 27 & Rom 3.24 & Job 2.5 & 24 & & & 1 Cor 13.12 & 16 \\
\hline & & Mt 6.25 & 29 & Rom 5.5 & Ezek 18.4 & 20 & & & 1Cor 13.12 & 21 \\
\hline & & Mt 6.34 & 29 & Rom 5.20 & Ezek 36.26 & 24 & & & 2 Cor 1.17 & 20 \\
\hline & & Mt 8.21 & 36 & Rom 7.12 & Sir 19.1 & 37 & & & 2 Cor 1.18 & 24 \\
\hline & & Mt 10.10 & 30 & Rom 7.14 & Mt 5.37 & 33 & & & 2 Cor $1.19-20$ & 23 \\
\hline & & Mt 10.28 & 9 & Rom 11.17 & Mt 7.15,16 & 12 & & & 2 Cor 3.18 & 14 \\
\hline & & Mt 15.2-20 & 25 & Rom 13.10 & Mt 10.16 & 12 & & & 2 Cor 3.18 & 20 \\
\hline & & Mt 15.16-20 & 32 & 1 Cor 4.2 & Mt 10.33 & 10 & & & Gal 4.24 & 15 \\
\hline & & Mt 22.39 & 9 & 1Cor 9.22 & Mt 26.69-75 & 13 & & & Col 2.17 & 20 \\
\hline & & Lk 10.27 & 9 & Gal 1.20 & Lk 8.45 & 27 & & & 1Thes 2.13 & 20 \\
\hline & & Lk 10.4-7 & 30 & Gal 2.2 & Lk 10.30-37 & 15 & & & 1Thes 5.6 & 15 \\
\hline & & In 3.21 & 35 & Gal 2.21 & Lk 13.28-30 & 24 & & & Heb 10.1 & 20 \\
\hline & & Jn 12.6 & 29 & Gal 2.3-5 & Lk 15.11-32 & 28 & & & Jas 5.12 & 20 \\
\hline & & Jn 14.6, 1.3 & 37 & Gal 2.11-14 & Lk 24.28 & 28 & & & Jas 5.12 & 23 \\
\hline & & Jn $15.12,13$ & 9 & Gal 2.12 & Jn 1.47 & 34 & & & 1 Jn 3.2 & 21 \\
\hline & & Jn 18.23 & 27 & Gal 2.14 & Jn 16.12 & 23 & & & $1 \mathrm{Jn} 3.2$ & 26 \\
\hline & & Acts $11.28-30$ & 29 & Gal 4.19 & Jn 11.34 & 27 & & & & \\
\hline & & Acts 16.1-3 & 8 & Gal 4.19 & Rom 3.7 & 40 & & & & \\
\hline & & Acts 23.2 & 27 & Gal 5.18 & Rom 3.7,8 & 1 & & & & \\
\hline & & Rom 2.25 & 8 & Gal 5.2 & Rom 3.8 & 32 & & & & \\
\hline & & Rom 9.1 & 28 & Gal 5.4 & Rom 6.13 & 18 & & & & \\
\hline & & 1 Cor $3.16,17$ & 26 & Gal 6.1 & Rom 10.10 & 3 & & & & \\
\hline & & 1 Cor $7.18-20$ & 43 & Col 2.17 & Rom 10.10 & 13 & & & & \\
\hline & & 1 Cor 9.15 & 21 & Col 2.17 & 1 Cor $9.20-22$ & 24 & & & & \\
\hline & & 1 Cor 9.22 & 40 & $1 \operatorname{Tim} 1.5$ & 1 Cor 10.4 & 40 & & & & \\
\hline & & 1 Cor $10.1-11$ & 38 & $1 \operatorname{Tim} 4.4$ & 1 Cor $15.53-56$ & 26 & & & & \\
\hline & & 1 Cor 10.13 & 8 & $2 \operatorname{Tim} 2.20-21$ & 2 Cor $2.15-16$ & 36 & & & & \\
\hline & & 1 Cor 15.15 & 30 & Jas 5.12 & 2 Cor 4.16 & 40 & & & & \\
\hline & & 1 Cor 15.53 & 42 & & $\mathrm{Gal} 2.13,14$ & 26 & & & & \\
\hline & & 2 Cor 2.16 & 42 & & Gal 4.25-26 & 33 & & & & \\
\hline & & Gal 1.20 & 28 & & Gal 6.1 & 22 & & & & \\
\hline & & Gal 1.20 & 43 & & Gal 6.1 & 26 & & & & \\
\hline & & Gal 2.12 & 8 & & Eph 4.25 & 2 & & & & \\
\hline & & Gal 2.14 & 8 & & Eph 4.25 & 15 & & & & \\
\hline & & Gal 2.14 & 43 & & Eph 4.28 & 18 & & & & \\
\hline & & $\mathrm{Gal} 2.3,4$ & 8 & & Phil 1.15-18 & 16 & & & & \\
\hline & & Gal 4.22-24 & 26 & & $1 \operatorname{Tim} 1.13$ & 9 & & & & \\
\hline & & Gal 5.2 & 8 & & $1 \operatorname{Tim} 1.13$ & 39 & & & & \\
\hline & & Gal 6.4 & 37 & & $1 \operatorname{Tim} 1.20$ & 8 & & & & \\
\hline & & Gal 6.6 & 30 & & Heb 5.14 & 39 & & & & \\
\hline & & Eph 4.25 & 6 & & 1Pet 5.8 & 24 & & & & \\
\hline & & Phil 1.8 & 28 & & 1Jn 1.8 & 40 & & & & \\
\hline & & & & & 1 Jn 2.21 & 31 & & & & \\
\hline & & & & & $1 \mathrm{Jn} 2.21$ & 37 & & & & \\
\hline & & & & & $1 \mathrm{Jn} 3.4$ & 31 & & & & \\
\hline & & & & & $1 \mathrm{Jn} 3.9$ & 40 & & & & \\
\hline & & & & & Rev 5.5 & 24 & & & & \\
\hline & & & & & $\operatorname{Rev} 14.5$ & 3 & & & & \\
\hline & & & & & $\operatorname{Rev} 14.5$ & 33 & & & & \\
\hline
\end{tabular}




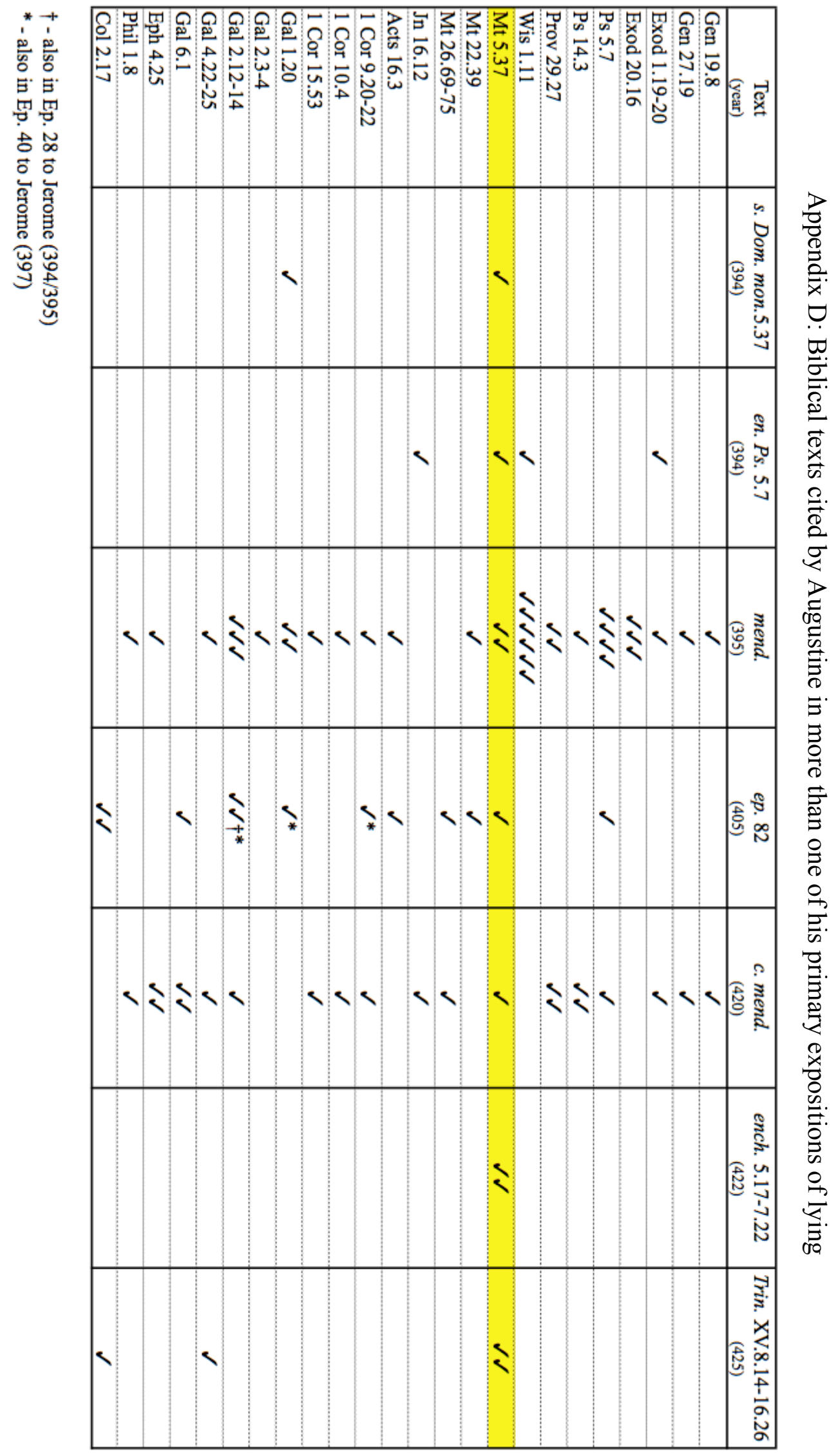




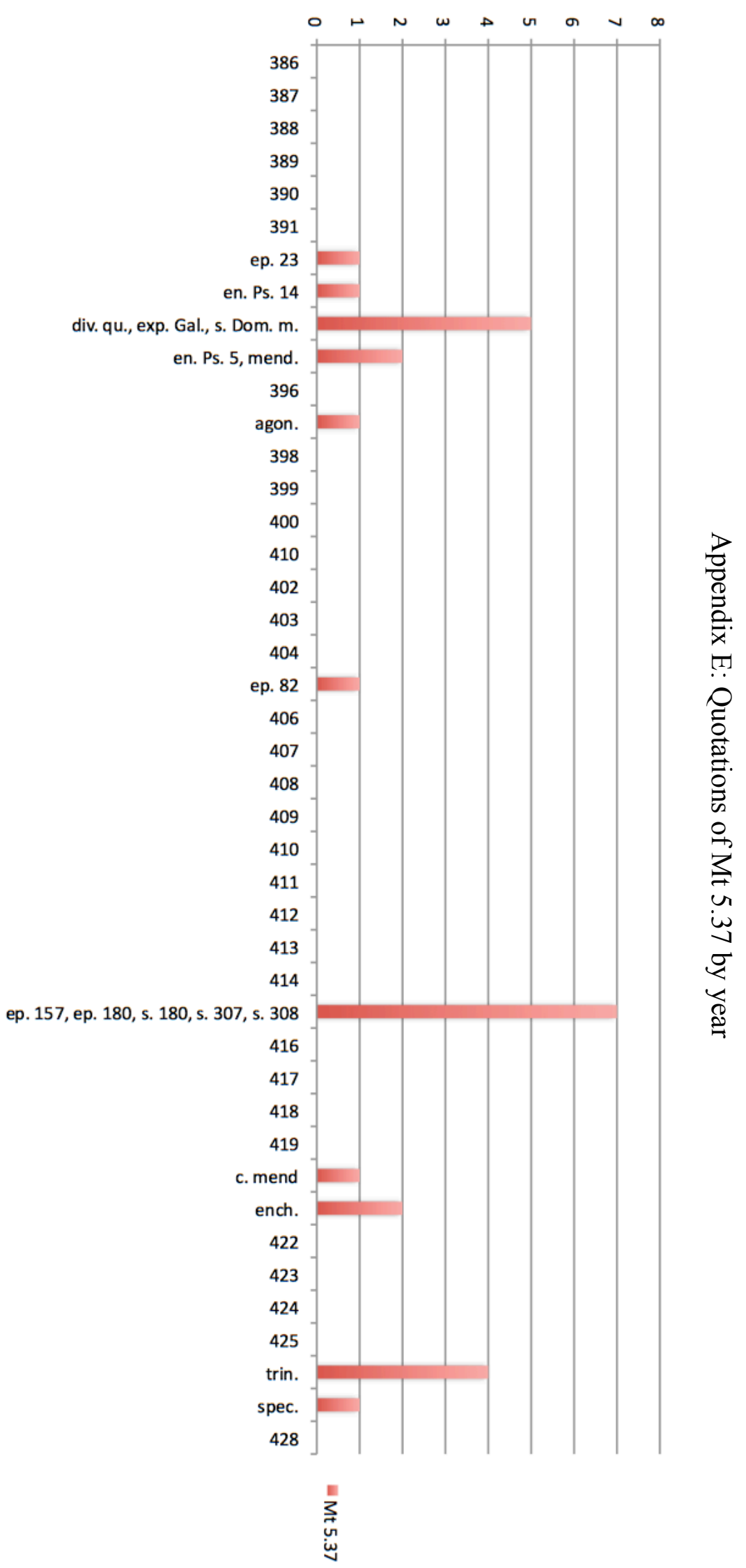




\section{A. Augustine's Works}

I have consulted the Corpus Christianorum, Series Latina (Turnholt: Brepols, 1953-) and the Patrologiae Cursus Completus Series Latina (Paris: Garnier, 1844-1864) for Augustine's texts. Abbreviations and titles of Augustine's texts follow the Oxford Guide for the Historical Reception of Augustine. I have used the most recent English translations where available, at times adapting and altering them in order to maintain fidelity to the original texts. Abbreviations of English translations refer to Fathers of the Church [FOTC], ed. Roy J. Deferrari (Washington D.C.: Catholic University of America: 1948-1962); The Works of Saint Augustine: A Translation for the 21st Century [WSA], ed. Boniface Ramsey (Hyde Park, N.Y.: New City Press, 1990-); A Select Library of the Nicene and Post-Nicene Fathers of the Christian Church [NPNF], ed. Philip Schaff (New York: The Christian Literature Company: 1887-1892).

\begin{tabular}{|c|c|c|}
\hline$\underline{\text { Abbreviation }}$ & $\underline{\text { Title }}$ & $\underline{\text { English Translation }}$ \\
\hline Acad. & Contra Academicos & FOTC 5 \\
\hline$a d n . I o b$ & Adnotationes in Iob & - \\
\hline agon. & De agone Christiano & FOTC 2 \\
\hline an. quant. & De animae quantitate & FOTC 4 \\
\hline beata $v$ & De beata vita & FOTC 5 \\
\hline cat. rud. & De catechizandis rudibus & Canning \\
\hline c. Adim. & Contra Adimantum & WSA I/19 \\
\hline c. adv. leg. & Contra adversarium legis et prophetarum & WSA I/18 \\
\hline c. ep. Man. & $\begin{array}{l}\text { Contra epistulam Manichaei quam vocant } \\
\text { fundamenti }\end{array}$ & WSA I/19 \\
\hline c. Faust. & Contra Faustum & WSA I/20 \\
\hline c. Fel. & De actis cum Felice Manichaeo & WSA I/19 \\
\hline c. Fort. & Contra Fortunatum & WSA I/19 \\
\hline c. Iul imp. & Contra Iulianum opus imperfectum & WSA I/25 \\
\hline c. Max. & Contra Maximinum Arrianum & WSA I/18 \\
\hline
\end{tabular}




\begin{tabular}{|c|c|c|}
\hline c. mend & Contra mendacium & FOTC 16 \\
\hline c. s. Arrian. & Contra sermonem Arrianorum & WSA I/18 \\
\hline c. Sec. & Contra Secundinem & WSA I/19 \\
\hline$c i v$ & De civitate Dei & WSA I/6-7 \\
\hline conf. & Confessiones & WSA I/1 \\
\hline conl. Max. & Conlatio cum Maximino Arrianorum episcopo & WSA I/18 \\
\hline corrept. & De correptione et gratia & WSA I/26 \\
\hline div. $q u$ & De diversis quaestionibus octoginta tribus & WSA I/12 \\
\hline doctr. Chr. & De doctrina Christiana & WSA I/11 \\
\hline en. Ps. & Enarrationes in Psalmos & WSA III/15-20 \\
\hline ench. & Enchiridion de fide et spe et caritate & WSA I/8 \\
\hline ep. & Epistulae & WSA II/1-4 \\
\hline ep. Io.tr. & In epistulam Iohannis tractatus & WSA III/14 \\
\hline exp. Gal. & Expositio epistulae Galatas & Plumer \\
\hline exp. prop. Rom. & $\begin{array}{l}\text { Expositio quarundam propositionem ex } \\
\text { epistula apostolic ad Romanos }\end{array}$ & Fredriksen Landes \\
\hline f. et symb. & De fide et symbolo & WSA I/8 \\
\hline gest. Pel. & De gestis Pelagii & WSA I/23 \\
\hline Gn. adv. Man. & De Genesi adversus Manichaeos & WSA I/13 \\
\hline Gn. litt. & De Genesi ad litteram & WSA I/13 \\
\hline Gn. litt. inp. & De Genesi ad litteram inperfectus & WSA I/13 \\
\hline Io. ev.tr. & In Iohannis evangelium tractatus & WSA III/12-13 \\
\hline lib. $a r b$. & De libero arbitrio & FOTC 59 \\
\hline mend. & De mendacio & FOTC 16 \\
\hline
\end{tabular}




\begin{tabular}{|c|c|c|}
\hline mor. & De moribus ecclesiae catholicae & WSA I/19 \\
\hline op. mon. & De opere monachorum & FOTC 16 \\
\hline ord. & De ordine & FOTC 5 \\
\hline praed. sanct. & $\begin{array}{l}\text { De praedestinatione sanctorum et de dono } \\
\text { perseverantiae }\end{array}$ & WSA I/26 \\
\hline$q u$. & Quaestiones in Heptateuchum & - \\
\hline$q u . e v$. & Quaestiones evangeliorum & - \\
\hline reg. & Regula & Lawless \\
\hline retr. & Retractiones & WSA I/2 \\
\hline$S$. & Sermones & WSA III/1-11 \\
\hline s. Dom. mon. & De sermone Domini in monte & WSA I/16 \\
\hline Simpl. & De diversis quaestionibus ad Simplicianum & WSA I/12 \\
\hline sol. & Soliloquia & FOTC 5 \\
\hline spec. & Speculum & - \\
\hline spir. et litt. & De spiritu et litteram & WSA I/23 \\
\hline Trin. & De Trinitate & WSA I/5 \\
\hline vera rel. & De vera religione & WSA I/8 \\
\hline
\end{tabular}

B. Other Works

Ables, Travis. Incarnational Realism: Trinity and the Spirit in Augustine and Barth. London and New York: Bloomsbury T\&T Clark, 2013.

Asad, Talal. "On Turture, or Cruel, Inhuman, and Degrading Treatment." In Arthur Kleinman, Veena Das, and Margaret Lock, eds., Social Suffering, 285-308. Berkeley: University of California Press, 1997.

Ayres, Lewis. Augustine and the Trinity. Cambridge: Cambridge University Press, 2010.

Babcock, William S. The Ethics of St. Augustine. Atlanta: Scholars Press, 1991. 
Baraz, Daniel. Medieval Cruelty: Changing Perceptions, Late Antiquity to the Early Modern Period. Ithaca, N.Y.: Cornell University Press, 2003.

Barth, Karl. Church Dogmatics Vol 3/1. Edited by G.W. Bromiley and T.F. Torrance, translated by J.W. Edwards, et al. Edinburgh: T\&T Clark, 1958.

Barth, Karl. Church Dogmatics Vol 3/2. Edited by G.W. Bromiley and T.F. Torrance, translated by G.W. Bromiley, et al. Edinburgh: T\&T Clark, 1960.

Berkouwer, G. C. Man: The Image of God. Grand Rapids, Mich.: Eerdmans, 1962.

Beyer, Tobias Winright, et al., Gerald J. "A Catholic Call to Abolish the Death Penalty." http://catholicmoraltheology.com/a-catholic-call-to-abolish-the-death-penalty/.

Boersma, Gerald. “The Context of Augustine's Early Theology of the Imago Dei." PhD Thesis, Durham University, 2013.

Bonner, Gerald. “Augustine's Doctrine of Man: Image of God and Sinner.” Augustinianum 24 (1984): 495-514.

Børresen, Kari Elisabeth. "Challenging Augustine in Feminist Theology and Gender Studies." In The Oxford Guide to the Historical Reception of Augustine. Edited by Karla Pollman, 135-141. Oxford: Oxford University Press, 2013.

. 'God's Image, Mans' Image?: Patristic Interpretations of Gen. 1,27 and I Cor. 11,7." In The Image of God: Gender Models in Judeo-Christian Tradition, ed. Kari Elisabeth Børresen, 187-209. Minneapolis: Fortress Press, 1995.

. "The Image of God and Gender Models in the Christian Tradition." In In the Image of God: Foundations and Objections within the Discourse on Human Dignity, edited by Alberto Meloni and Riccardo Saccenta, 359-367. Berlin: LIT Verlag, 2010.

Bowlin, John. "Augustine on Justifying Coercion." Annual of the Society of Christian Ethics 17 (1997): 49-70.

Brachtendorf, Johannes. Die Struktur des menschlichen Geistes nach Augustinus: Selbstreflexion und Erknenntnis Gottes in "De Trinitate." Hamburg: Meiner, 2000.

Brinton, Alan. "St. Augustine and the Problem of Deception in Religious Persuasion." Religious Studies 19 (1983): 437-50.

Brown, Peter. Augustine of Hippo: A Biography. Berkeley: University of California Press, 2000.

Burnaby, John. Amor Dei: A Study of the Religion of St. Augustine. London: Hodder \& Stoughton, 1938. 
Cairns, David. The Image of God in Man. London: SCM Press, 1953.

Calvin, John. Institutes of the Christian Religion. Edited by John T. McNeill, translated by Ford Lewis Battles. Louisville, Kent.: Westminster John Knox Press, 1960.

Canning, Raymond, trans., intro., and notes. Instructing Beginners in Faith, edited by Boniface Ramsey. Hyde Park, N.Y.: New City Press, 2006.

Carroll, James T. "He Promised Much and Did It All: Augustine and Historians." In Christopher T. Daly, John Doody, and Kim Paffenroth, eds. Augustine and History, 77-88. Lanham, MD: Lexington Books, 2008.

Cavanaugh, William. "Torture and Eucharist: A Regretful Update." In Torture is a Moral Issue, edited by George Hunsinger, 92-112. Grand Rapids, Mich.: Eerdmans, 2008.

Chrysostom, John. Homilies on Genesis 18-45, trans. Robert C. Hill, Fathers of the Church 82. Washington D.C.: Catholic University Press, 1991.

Davis, G. Scott. "A Vindication of Theology: A Response to Alain Epp Weaver." Journal of Religious Ethics 29, no.1 (2001): 79-85.

Decosimo, David. “Just Lies: Finding Augustine's Ethics of Public Lying in His Treatments of Lying and Killing.” Journal of Religious Ethics 38, no.4 (2010): 661-697.

Dodaro, Robert. “Augustine's Revision of the Heroic Ideal.” Augustinian Studies 36, no.1 (2005): 141-157.

. "Eloquent Lies, Just Wars and the Politics of Persuasion: Reading Augustine's City of God in a 'Postmodern' World.” Augustinian Studies 25 (1994): 77-137.

. Christ and the Just Society in the Thought of Augustine. Cambridge: Cambridge University Press, 2004.

Drever, Matthew. Image, Identity, and the Forming of the Augustinian Soul. Oxford: Oxford University Press, 2013.

Drobner, Hubertus. "Studying Augustine: An overview of recent research." In Augustine and His Critics: Essays in Honor of Gerald Bonner, edited by Robert Dodaro and George Lawless. London: Routledge, 2000.

Ephrem the Syrian, "Commentary on Genesis." In Selected Prose Works, translated by Edward G. Mathews, Jr. and Joseph P. Amar, edited by Kathleen McVey, 67-216. Washington, D.C.: Catholic University of America Press, 1994.

Erhueh, Anthony O. Vatican II: Image of God in Man. Rome: Urbaniana University Press, 1987. 
Feehan, Thomas D. “Augustine on Lying and Deception.” Augustinian Studies 19 (1988): 131-139.

. “Augustine's Own Examples of Lying." Augustinian Studies 22 (1991): 165190.

. "The Morality of Lying in Saint Augustine." Augustinian Studies 21 (1990): 6781.

Fitzgerald, Allan D., ed. Augustine Through the Ages. Grand Rapids, Mich.: Eerdmans, 2009.

Fleming, Julie A. "The Helpful Lie: The Moral Reasoning of Augustine and John Cassian.” Ph.D. dissertation, Catholic University of America, 1993.

Fredriksen, Paula. "Augustine and Israel: Interpretatio ad Litteram, Jews and Judaism in Augustine's Theology of History." In Engaging Augustine on Romans: Self, Context, and Theology in Interpretation, eds. Daniel Patter and Eugene TeSelle, 91-110. Harrisburg, Penn.: Trinity Press International, 2002.

Fredriksen Landes, Paula, ed and trans. Augustine on Romans. Chico, Calif:: Scholar's Press, 1982.

Fulkerson, Mary McClintock. "The imago Dei and a Reformed Logic for Feminist/Womanist Critique." In Feminist and Womanist Essays in Reformed Dogmatics, eds. Amy Plantinga Pauw and Serene Jones, 95-106. Louisville, Kent.: Westminster John Knox Press, 2006.

Gilson, Etienne. The Christian Philosophy of Saint Augustine. Translated by L. E. M. Lynch. London: Victor Gallancz, 1960.

Gioia, Luigi. The Theological Epistemology of Augustine's De Trinitate. Oxford: Oxford University Press, 2008.

Gramigna, Remo. "Augustine on lying: A theoretical framework for the study of types of falsehood." Sign Systems Studies 414 (2013): 446-487.

Gregory, Eric. Politics and the Order of Love: An Augustinian Ethic of Democratic Citizenship. Chicago: University of Chicago Press, 2008.

Griffiths, Paul J. Lying: An Augustinian Theology of Duplicity. Grand Rapids, Mich.: Brazos Press, 2004.

. "The Gift and the Lie: Augustine on Lying." Communio: International Catholic Review 26 (1999): 5-30.

. "Just War: An exchange." First Things 122 (2002): 31-36. 
Gushee, David. The Sacredness of Human Life: Why an Ancient Biblical Vision is Key to the World's Future. Grand Rapids, Mich.: Eerdmans, 2013.

Harmless, William, ed. Augustine in His Own Words. Washington, D.C.: Catholic University of America Press, 2010.

Harrison, Carol. Rethinking Augustine's Early Theology. Oxford: Oxford University Press, 2008.

Heidl, György. Origen's Influence on the Young Augustine: A Chapter of the History of Origenism. Piscataway, N.J.: Gorgias Press, 2003.

Heijke, J. "The Image of God According to St. Augustine." Studies in the Christian Perpetuation of the Classics 10 (1956): 3-11.

. “St. Augustine's Comments on 'Imago Dei."” Classical Folia, Supplement 3. 1960.

Herdt, Jennifer. Putting On Virtue: The Legacy of the Splendid Vices. Chicago: University of Chicago Press, 2008.

Hombert, Pierre-Marie. Nouvelles recherches de chronologie augustinienne. Vol. 163. Paris: Institut d'Études augustiniennes, 2000.

Howard, Tal, ed. Imago dei: Human Dignity in Ecumenical Perspective. Washington, DC: Catholic University of America Press, 2013.

Hunsinger, George, ed. Torture is a Moral Issue: Christians, Jews, Muslims, and People of Conscience Speak Out. Grand Rapids, Mich.: Eerdmans, 2008.

Jaspers, Karl. The Great Philosophers: The Foundations. Edited by Hannah Arendt, translated by R. Mannheim. New York: Harcourt, Brace \& World, 1962.

Joas, Hans. The Sacredness of the Person: A New Genealogy of Human Rights. Translated by Alex Skinner. Washington, D.C.: Georgetown University Press, 2013.

Johnson, James Turner. "Can a Pacifist Have a Conversation with Augustine?: A Response to Alain Epp Weaver.” Journal of Religious Ethics 29, no.1 (2001): 8793.

Kamitsuka, Margaret D. Feminist Theology and the Challenge of Difference. Oxford: Oxford University Press, 2007.

Kany, Roland. "De Trinitate." In The Oxford Guide to the Historical Reception of Augustine, vol 1, eds. Karla Pollmann and Willemien Otten, 387-399. Oxford: Oxford University Press, 2013. 
Kelsey, David H. Eccentric Existence: A Theological Anthropology, 2 vols. Louisville, Kent.: Westminster John Knox Press, 2009.

Kunzelmann, A. "Die Chronologie der Sermones des hl. Augustinus." Miscellania Agostiniana 2 (1931): 417-520.

La Bonnardière, A.M. Reserches de chronologie augustinienne. Paris, 1965.

Lactantius, Divine Institutes, translated with an introduction and notes by Anthony Bowen and Peter Garnsey. Liverpool: Liverpool University Press, 2003.

Ladner, Gerhart B. The Idea of Reform: Its Impact on Christian Thought and Action in the Age of the Fathers. Cambridge: Harvard University Press, 1959.

Lancel, Serge. St. Augustine, trans. Antonia Neville. London: SCM Press, 2002.

Lawless, George. Augustine of Hippo and his Monastic Rule. Oxford: Clarendon Press, 1987.

Le Landais, Maurice. "Deux années de prédication de saint Augustin.” Études augustiniennes (1953): 9-95.

Levenick, Christopher. "Exceptis Igitur Iocis: Augustine on Lying, Joking, and Jesting." Augustinian Studies 35, no.2 (2004): 301-323.

Luther, Martin. Lectures on Genesis. Jaroslav Pelikan, ed. Luther's Works Vol. I. Saint Louis: Concordia Publishing House, 1958.

Madec, G. Introduction aux "Révisions" et à la Lecture des Oeuvres de Saint Augustin, Collection des Éstudes Augustiniennes: Série Antiquitié 150. Paris: Institut d’Études Augustiniennes, 1996.

Markus, Robert. Christianity and the Secular. Notre Dame: University of Notre Dame, 2006.

. "Imago' and 'similitudo' in Augustine." Revue des études augustiniennes (1963): 125-143.

. Saeculum: History and Society in the Thought of St. Augustine. Cambridge: Cambridge University Press, 1970.

Marrou, Henri. St. Augustine and His Influence Through the Ages. New York: Harper, 1957.

Mathewes, Charles. An Augustinian Theology of Public Life. Cambridge: Cambridge University Press, 2008.

Mayer, Cornelius, ed. Augustinus-Lexikon. Basel:Schwabe \& Co., 1986-. 
McCool, Gerald A. "The Ambrosian Origin of St. Augustine's Theology of the Image of God in Man." Theological Studies (1959): 62-81.

McCrudden, Christopher, ed. Understanding Human Dignity, Proceedings of the British Academy. Oxford: Oxford University Press, 2014.

McLeese, Constance E. "Augustinian Exegesis and Sexist Canon from the New Testament." In Augustine and the Bible, ed. and trans. Pamela Bright, 282-300. Notre Dame: Notre Dame University Press, 1999.

Meconi, David Vincent. The One Christ: St. Augustine's Theology of Deification. Washington, D.C.: Catholic University of America Press, 2013.

Milbank, John. Theology and Social Theory: Beyond Secular Reason. Oxford: Blackwell Publishers Inc., 1990.

Moyn, Sam. The Last Utopia: Human Rights in History. Cambridge, Mass.: Belknap Press, 2010.

Müller, Hildegung. "Enarrationes in Psalmos." In Augustinus-Lexikon. Cornelius Mayer, ed. Basel:Schwabe \& Co., 1986-.

Newey, Glen. "Political Lying: A Defense.” Public Affairs Quarterly 11, no.2 (1997): 93116.

Nisula, Timo. Augustine and the Functions of Concupiscence. Leiden: Brill Academic Publishers, 2012.

O'Daly, Gerard. Augustine's City of God: A Reader's Guide. Oxford: Oxford University Press, 1999.

Pellegrino, Edmund D., Adam Schulman, and Thomas W. Merrill, eds. Human Dignity and Bioethics. Notre Dame: University of Notre Dame Press, 2009.

Pollmann, Karla, ed. The Oxford Guide to the Historical Reception of Augustine. Oxford: Oxford University Press, 2013.

Power, Kim. Veiled Desire: Augustine on Women. New York: Continuum, 1996.

Ramsey, Boniface "Introduction." In The Augustine Catechism: Enchiridion on Faith, Hope, and Love, trans. Bruce Harbert. Hyde Park, NY: New City Press, 1999.

. "Two Traditions of Lying and Deception in the Early Church." Thomist: A Speculative Quarterly Review 49, no.4 (1985): 504-533.

. "De Mendacio/Contra Mendacium." In Augustine Through the Ages. Edited by Allan Fitzgerald. Grand Rapids, Mich.: Eerdmans, 2009. 
Rist, John. Augustine: Ancient Thought Baptized. Cambridge: Cambridge University Press, 1994.

Scarry, Elaine. The Body in Pain: The making and unmaking of the world. Oxford: Oxford University Press, 1985.

Shaw, Brent D. Sacred Violence: African Christians and Sectarian Hatred in the Age of Augustine. Cambridge: Cambridge University Press, 2011.

. "Augustine and Men of Imperial Power." Lecture at the Center for the Study of Christianity [http://www.csc.org.il/template/default.aspx?PageId=107]

Somers, H. "Image de Dieu: Les sources de l'exégèse augustienne." Revue des études augustiniennes 7, no.2 (1961): 105-125.

Soskice, Janet Martin. “Imago Dei and Sexual Difference.” Concilium (2006): 35-41.

Soulen, and Linda Woodhead, R. Kendall, eds. God and Human Dignity. Grand Rapids: Eerdmans, 2006.

Stark, Judith Chelius. "Augustine on Women: In God's Image, but Less So" in Feminist Interpretations of Augustine, ed. Judith Chelius Stark, 215-241. University Park, Penn.: Pennsylvania State University Press, 2007.

, ed. Feminist Interpretations of Augustine. University Park, Penn.: Pennsylvania State University Press, 2007.

Sullivan, John Edward. The Image of God: The Doctrine of St. Augustine and Its Influence. Dubuque: The Priority Press, 1963.

Tanner, Kathryn. Christ the Key. Cambridge: Cambridge University Press, 2010.

TeSelle, Eugene. Augustine the Theologian. New York: Herder and Herder, 1970.

. "Response I - Augustine and Theology." Augustinian Studies 36:1 (2005): 7183.

Teske, Roland J. “The Image and Likeness of God in St. Augustine's De Genesi as litteram liber imperfectus." Augustinianum 30, no.2 (1990): 441-451.

. "Origen and St. Augustine's First Commentaries on Genesis." Origeniana Quinta (1992): 179-185.

. To Know God and the Soul: Essays on the Thought of Saint Augustine.

Washington, D.C.: Catholic University of America Press, 2008.

U.N. General Assembly. Convention against Torture and other Cruel, Inhuman or Degrading Treatment or Punishment. 1984. 
. Universal Declaration of Human Rights. 1948.

van Bavel, Tarsicius Jan. "Woman as the Image of God in Augustine's 'De trinitate XII" in Signum Pietatis: Festgabe für Cornelius Petrus Mayer OSA zum 60 Geburtstag, 267-288. Würzburg: Augustinus-Verlag, 1989.

von Heyking, John. Augustine and Politics as Longing in the World. Columbia, Mo.: University of Missouri Press, 2001.

Waldron, Jeremy. Dignity, Rank, and Rights. Oxford: Oxford University Press, 2012.

Weaver, Alain Epp. "Unjust Lies, Just Wars?" A Christian Pacifist Conversation with Augustine." Journal of Religious Ethics 29, no.1 (2001): 51-78.

Weber, Otto Foundations of Dogmatics Vol 1. Translated by Darrell L. Guder. Grand Rapids, Mich.: Eerdmans, 1981.

Weiss, Daniel. "Direct Divine Sanction, the Prohibition of Bloodshed, and the Individual as Image of God in Classical Rabbinic Literature." Journal of the Society of Christian Ethics 32, no.2 (2012): 22-38.

Wetzel, James. "Body Double: St. Augustine and the Sexualized Will." In Weakness of the Will from Plato to the Present, edited by Tobias Hofmann, 58-81.

Washington, D.C.: Catholic University Press, 2008.

. "Saint Augustine Lecture 2012: A Tangle of Two Cities." Augustinian Studies 43, no.1/2 (2012): 5-23.

Williams, Rowan. "Sapientia and the Trinity: Reflections on the De Trinitate." In B. Bruning, et al. (eds.), Collectanea Augustiniana: Mélanges T. J. Bavel, I:317-32. Leuven: Leuven University Press, 1990.

Witte, Jr. and Frank S. Alexander, John, eds. Christianity and Human Rights: An Introduction. Cambridge: Cambridge University Press, 2011.

Wolterstorff, Nicholas. Justice: Rights and Wrongs. Princeton: Princeton University Press, 2008.

Zarb, Seraphinus M. "Chronologia operum Sancti Augustini." Angelicum 10, no.3 (1933): 359-396; 10, no.4 (1933): 478-512; 11, no.1 (1934): 78-91. 